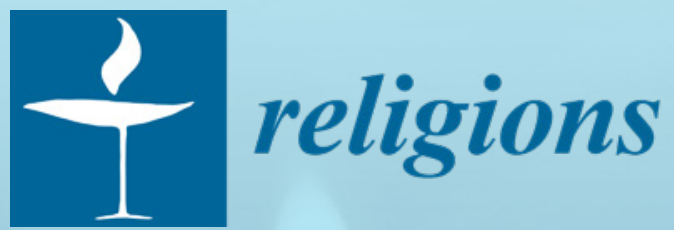

Religion, Power,

and Resistance

New Ideas for a Divided World

Edited by

Anna Halafoff, Caroline Starkey, Sam Han and James Spickard Printed Edition of the Special Issue Published in Religions 


\section{Religion, Power, and Resistance}





\section{Religion, Power, and Resistance}

New Ideas for a Divided World

Editors

Anna Halafoff

Caroline Starkey

Sam Han

James Spickard 
Editors

Anna Halafoff

Deakin University

Australia

James Spickard

University of Redlands

USA
Caroline Starkey

University of Leeds

UK

\section{Sam Han}

The University of Western Australia

Australia

\section{Editorial Office}

MDPI

St. Alban-Anlage 66

4052 Basel, Switzerland

This is a reprint of articles from the Special Issue published online in the open access journal Religions (ISSN 2077-1444) (available at: https://www.mdpi.com/journal/religions/special_issues/ dividedworld).

For citation purposes, cite each article independently as indicated on the article page online and as indicated below:

LastName, A.A.; LastName, B.B.; LastName, C.C. Article Title. Journal Name Year, Article Number, Page Range.

\section{ISBN 978-3-03936-864-8 (Hbk)}

ISBN 978-3-03936-865-5 (PDF)

Cover image courtesy of James Spickard: Church Candles.

(C) 2020 by the authors. Articles in this book are Open Access and distributed under the Creative Commons Attribution (CC BY) license, which allows users to download, copy and build upon published articles, as long as the author and publisher are properly credited, which ensures maximum dissemination and a wider impact of our publications.

The book as a whole is distributed by MDPI under the terms and conditions of the Creative Commons license CC BY-NC-ND. 


\section{Contents}

About the Editors $\ldots \ldots \ldots \ldots \ldots \ldots \ldots \ldots \ldots \ldots \ldots \ldots \ldots$

Anna Halafoff, Sam Han, Caroline Starkey and James V. Spickard

Introduction to the Special Issue: Religion, Power, and Resistance: New Ideas for a Divided

World

Reprinted from: Religions 2020, 11, 306, doi:10.3390/rel11060306 . . . . . . . . . . . . . 1

James V. Spickard

The Sociology of Religion in a Post-Colonial Era: Towards Theoretical Reflexivity

Reprinted from: Religions 2019, 10, 18, doi:10.3390/rel10010018 . . . . . . . . . . . . . . 5

Federico Settler

Curating Violence: Reflecting on Race and Religion in Campaigns for Decolonizing the University in South Africa

Reprinted from: Religions 2019, 10, 310, doi:10.3390/rel10050310 . . . . . . . . . . . . . . 19

Tak-ling Terry Woo

A Flexible Indeterminate Theory of Religion: Thinking through Chinese Religious Phenomena

Reprinted from: Religions 2019, 10, 428, doi:10.3390/rel10070428 . . . . . . . . . . . . . 33

\section{Cristián Parker}

Popular Religions and Multiple Modernities: A Framework for Understanding Current Religious Transformations

Reprinted from: Religions $2019,10,565$, doi:10.3390/rel10100565 . . . . . . . . . . . . . 53

Michael Perry Kweku Okyerefo

Scrambling for the Centre: Ghana's New Churches as an Alternative Ideology and Power

Reprinted from: Religions 2019, 10, 668, doi:10.3390/rel10120668 . . . . . . . . . . . . . . 69

\section{Rafael Cazarin}

The Social Architecture of Belonging in the African Pentecostal Diaspora

Reprinted from: Religions 2019, 10, 440, doi:10.3390/rel10070440 . . . . . . . . . . . . . . 83

Hossein Godazgar

From 'Islamism' to 'Spiritualism'? The Individualization of 'Religion' in Contemporary Iran

Reprinted from: Religions 2020, 11, 32, doi:10.3390/rel11010032 . . . . . . . . . . . . . . . 99

\section{Anna Clot-Garrell and Mar Griera}

Beyond Narcissism: Towards an Analysis of the Public, Political and Collective Forms of Contemporary Spirituality

Reprinted from: Religions 2019, 10, 579, doi:10.3390/rel10100579 . . . . . . . . . . . . . 125

Peter Beyer and Lori G. Beaman

Dimensions of Diversity: Toward a More Complex Conceptualization

Reprinted from: Religions 2019, 10, 559, doi:10.3390/rel10100559 . . . . . . . . . . . . . 141

\section{Alan G. Nixon}

'Non-Religion' as Part of the 'Religion' Category in International Human Rights

Reprinted from: Religions 2020, 11, 79, doi:10.3390/rel11020079 . . . . . . . . . . . . . 157 
Anna Halafoff, Heather Shipley, Pamela D. Young, Andrew Singleton, Mary Lou Rasmussen and Gary Bouma

Complex, Critical and Caring: Young People's Diverse Religious, Spiritual and Non-Religious Worldviews in Australia and Canada

Reprinted from: Religions 2020, 11, 166, doi:10.3390/rel11040166 . . . . . . . . . . . . . . . . 175 


\section{About the Editors}

Anna Halafoff, Dr., is an Associate Professor in Sociology and a member of the Alfred Deakin Institute at Deakin University in Australia. She is also a Research Associate of the UNESCO Chair in Interreligious and Intercultural Relations-Asia Pacific, at Monash University. Her current research interests include religious diversity, preventing violent extremism, religion and young people, worldviews education, and Buddhism in Australia. Her recent books include The Multifaith Movement: Global Risks and Cosmopolitan Solutions (Springer 2013), Education about Religions and Worldviews: Promoting Intercultural and Interreligious Understanding in Secular Societies (Routledge, 2016 edited with Elisabeth Arweck and Daniel Boisvert), and Re-Enchanting Education and Spiritual Wellbeing: Fostering Belonging and Meaning-making for Global Citizens (Routledge, 2017 edited with Marian DeSouza).

Sam Han, Dr., is an interdisciplinary social scientist, working primarily in the areas of social/cultural/critical theory, new media studies, and religion, as well as their various overlaps and nodal points. He is a Senior Lecturer of Anthropology and Sociology in the School of Social Sciences at the University of Western Australia. He is the author of many books, and recent titles include (Inter)Facing Death: Life in Global Uncertainty (Routledge, 2020), Technologies of Religion: Spheres of the Sacred in a Post-Secular Modernity (Routledge, 2016), and Digital Culture and Religion in Asia (Routledge, 2015) (with Kamaludeen Mohamed Nasir).

Caroline Starkey, Dr., is an Associate Professor of Religion and Society at the University of Leeds. Her research focuses on religion in contemporary Britain, particularly in relation to minority religions and gender. Her monograph, Women in British Buddhism: Connection, Commitment, Community, was published by Routledge in 2020 .

James Spickard (Emeritus Professor of Sociology and Anthropology) recently retired from the University of Redlands, where he taught courses on social theory, research design, the sociology of religion, social inequality, and homelessness, among other topics. He has published six books and over 75 journal articles and book chapters on religion in contemporary society, human rights, social research, non-Western social theory, and the social foundations of ethics. He is President-Elect of the Association for the Sociology of Religion and Past-President of the International Sociological Association's Research Committee on the Sociology of Religion. He is working on a book on religion's future in the contemporary world. 

Editorial

\title{
Introduction to the Special Issue: Religion, Power, and Resistance: New Ideas for a Divided World
}

\author{
Anna Halafoff ${ }^{1, *(1)}$, Sam Han ${ }^{2}\left(\mathcal{D}\right.$, Caroline Starkey $^{3}$ and James V. Spickard ${ }^{4}(\mathbb{C}$ \\ 1 Faculty of Arts and Education, Deakin University, 221 Burwood Highway, Melbourne, VIC 3125, Australia \\ 2 School of the Social Sciences/Anthropology \& Sociology, The University of Western Australia, M257, \\ Perth 6009, Australia; sam.han@uwa.edu.au \\ 3 School of Philosophy, Religion and History of Science, University of Leeds, Leeds LS2 9JT, UK; \\ C.Starkey@leeds.ac.uk \\ 4 Sociology \& Anthropology, University of Redlands, 1200 East Colton Ave P.O. Box 3080, \\ Redlands, CA 92373, USA; jim_Spickard@redlands.edu \\ * Correspondence: anna.halafoff@deakin.edu.au
}

Received: 2 June 2020; Accepted: 18 June 2020; Published: 23 June 2020

The world is currently gripped by pressing environmental, social, and economic challenges. Many people have lost faith that existing power structures can handle them, but they have come to no consensus on solutions. We thus find ourselves in increasingly divided societies, riven by ideological battles for the future of the human and the more-than-human world. In its myriad forms, religion plays many roles in this picture. It can be an underlying source of divisions as well as a powerful means of addressing them.

The sociology of religion is also changing. Scholars no longer see religion as centred only on churches, mosques, synagogues, temples, and so on, nor do they see it as simply focused on supernatural beliefs. Therefore, they now investigate folk religions, indigenous knowledge systems, contemporary spiritualities, and non-religious worldviews as well as formal religious life, and they look for new concepts to help them grasp this religious diversity. They discover that the old binary frameworks of 'private' vs. 'public' religion and 'religious' vs. 'secular' no longer so easily apply. Theoretical frameworks derived from one context cannot so simply be transposed to another. Lived experiences of diverse religious forms do not always match up with ideological or theological underpinnings. In short, we are living in a time of religious complexity, where religion plays a role in both creating and ameliorating conflict and division.

The articles in this Special Issue were drawn from the July 2018 World Congress of Sociology-the International Sociological Association (ISA)'s 19th quadrennial meeting. They come from sessions organised by the ISA's Research Committee on the Sociology of Religion (RC22). The RC22's theme was 'Religion, Power, and Resistance: New Ideas for a Divided World' and it explored the following questions: What is religion's role in this situation: as a creator of divisions, as a locus of power, and as a ground of resistance? How does religion influence our divided societies? How is religion influenced in turn?

The RC22 papers focused on religion and power, intersectional violence, social divisions, and also resistance to power, violence, and division. They included the following themes: religion and nationalism; religion and social theory; religion and diversity; religion and violent extremism; religion and gender inequality; religion and sexuality inequality; religion and environmental crises; and religion and violent and nonviolent social movements.

The editors invited a selection of RC22 World Congress participants to contribute to this Special Issue, as a way to share their ground-breaking, recent research on religion. We chose both established and emerging international scholars, in order to make the best use of the high-quality, open-access platform that the journal Religions provides. As a part of the RC22's commitment to decentering the 
sociology of religion from the Global North and West, we selected participants from a wide range of regions. We thus included case studies and/or scholars from Africa, Asia, Australia, Europe, the Middle East, and North and South America.

James V. Spickard's 2018 RC22 Presidential Address, on 'The Sociology of Religion in a Post-Colonial Era: Towards Theoretical Reflexivity' argues that the discipline of sociology remains shaped by its 19th century European historical-cultural origins. He calls for sociologists to interrogate these inherited concepts, uncover their limitations, and understand how the current social, political, and economic situation continues to shape contemporary sociology. He also contends that a post-colonial sociology needs to expand its theoretical canon to include scholarship from non-Western locations, for epistemological as well as for ethical reasons.

Federico Settler's article focuses on how university staff and students in South Africa's campaigns to decolonise higher education were met with violent repression, yet how they used that conflict as an opportunity for critical reflection on resistance and religion. He examines three 'curatorial moments' created by himself and his colleagues: a Prisoners' Memorial, the Poetics of Protest event, and Public Sculpture. These events enabled students and staff to reflect deeply on their own experiences of violence, power relations, and decolonial pedagogy.

Terry Tak-ling Woo's contribution explores how to use Chinese religious phenomena to expose the inadequacy of applying Western theories, such as secularisation, to Chinese experiences. Woo stresses the diversity of religious thought in China, spanning Confucianism, Daoism, and Buddhism, newer religious movements, and pan-Chinese quasi-religious practices. She contends that this variety of religions and attitudes towards religion lends itself to a more flexible and indeterminate theoretical approach rather than seeking one overarching theory.

Cristián Parker's article, which focuses on Latin America, Africa, Asia, and the Middle East, argues that theoretical approaches that focus on lived religion and symbolic action offer a better framework for understanding popular, ethnic, and folk religions in the Global South than do approaches based on multiple modernities. He thus challenges the notion that Western theories are universal theories and evokes a new sociology of religion informed by an emerging post-rationalist paradigm.

Michael Perry Kweku Okyerefo's contribution examines the ideologies and power dynamics of Ghana's New Churches. Drawing on media analysis and interviews, he presents case studies of strategies that two Pentecostal-charismatic organisations used to gain political access and influence in Ghana's increasingly socio-culturally diverse society.

Rafael Cazarin's article examines how Pentecostal churches in South Africa and Spain create a social architecture of belonging for members of the African diaspora in these societies and globally. Cazarin argues that they do so by providing a religious narrative that transforms them from a marginalised minority to a more powerful group that occupies a higher moral ground.

Hossein Godazgar's contribution examines a movement from 'Islamism' to 'Spiritualism' in contemporary Iran. Through the analysis of media and interview data, he argues that while the influence of mosques is waning, there has been a rise of interest in less institutionalised and politicised spaces of shrines and places of pilgrimage over recent years. This shift is evidence for the growth of a more individualistic spirituality.

Anna Clot-Garrell and Mar Griera's article analyses public, political, and collective forms of contemporary spirituality in Catalonia. It questions the dominant view that spirituality takes place in the private sphere and is linked to consumerism and narcissistic individualism. Instead, the authors discover that it is far more public and is socially and politically engaged, demonstrating an ethics of responsibility.

Peter Beyer and Lori Beaman's contribution presents the findings of the Religion and Diversity Project, which was centred on Canada and included evidence from the United Kingdom, the United States of America, Australia and France. It argues that religious diversity is becoming both more complex and more intersectional, particularly regarding sex and gender diversities. They also conclude that the category of non-religion requires further investigation in contemporary societies. 
Alan G. Nixon's article examines the rising persecution of the 'non-religious' in the context of how 'non-religion' is treated as part of the category 'religion' in International Human Rights instruments and laws. He argues for the need to examine and challenge the privileging of religion, to counter discrimination and persecution of the non-religious and to advance their rights globally.

Anna Halafoff, Heather Shipley, Pamela D. Young, Andrew Singleton, Mary Lou Rasmussen, and Gary Bouma's contribution problematises the claim that young people are apathetic towards religion. The authors present their research findings on young people's diverse religious, spiritual, and non-religious worldviews in Australia and Canada. They argue that these young people negotiate their worldview identities —including religious and sexuality identities—in complex, critical, and caring ways, which are often characterised by hybridity and questioning.

These articles focus on religion, power and resistance in multiple ways and contexts. A prevalent theme among them is the decolonising and decentering of sociology written from Northern and Western perspectives, as discussed in Spickard's, Woo's and Parker's theoretical articles and Settler's contribution focussed on pedagogy. Another theme is disrupting our discipline's dominant emphases on the study of conventional religions, by focusing on the spiritual and non-religious, as is evident in Godazgar's examination of 'Spiritualism' in Iran, Clot-Garrell and Griera's work on contemporary spirituality in Catalonia, and Nixon's article on the non-religious and human rights law. A further theme is the strategies used by newer and popular forms of religion to challenge existing power structures, such as Okyerefo's case study of Ghana's New Churches and Cazarin's examples of Pentecostal churches in South Africa and Spain. Finally, themes of complexity, intersectionality, and inclusion emerge in the articles by Beyer and Beaman, and Halafoff et al., who argue that to gain deep insights into a situation, research must engage with diverse participants' views and experiences in ways that both centre them and accurately reflect their complex and lived realities.

As this Special Issue's editors, we hope that these articles generate robust discussion and critical reflection on the nexus of religion, spirituality, and non-religion with power, violence, and justice, resistance and responsibility. We hope that these contributions from diverse settings can disrupt dominant paradigms and contribute to the creation of new ideas that advance the discipline of the sociology of religion.

Funding: This research received no external funding.

Conflicts of Interest: The authors declare no conflict of interest.

(C) 2020 by the authors. Licensee MDPI, Basel, Switzerland. This article is an open access article distributed under the terms and conditions of the Creative Commons Attribution (CC BY) license (http://creativecommons.org/licenses/by/4.0/). 



\title{
Article \\ The Sociology of Religion in a Post-Colonial Era: Towards Theoretical Reflexivity
}

\author{
James V. Spickard 1 \\ Department of Sociology \& Anthropology, University of Redlands, 1200 Colton Avenue, Redlands, CA 92373, \\ USA; Jim_spickard@redlands.edu
}

Received: 10 October 2018; Accepted: 3 November 2018; Published: 28 December 2018

\begin{abstract}
This article makes two points. First, it argues that sociology, like all knowledge, is shaped, though not determined, by its historical-cultural origins. Early sociology arose in 19th-century Europe and its core concepts were shaped by that era-both in what they reveal about society and what they hide. We now realize this, so we sociologists of religion need to examine our inherited concepts to understand those concepts' limitations. We also need to include an analysis of the way the current historical-cultural situation shapes sociology today. This is the theoretical reflexivity called for in the title. Second, the article argues that expanding sociology's conceptual canon to include insights from other historical-cultural locations is more than just an ethical matter. It is also epistemological. Sociology does not make progress unless it includes insights from as many standpoints as possible. This does not mean that all insights are equal. It does mean that all have the potential to improve sociological understanding. Whether or not they actually do so is a matter for the scientific process to decide.
\end{abstract}

Keywords: sociology of religion; post-colonial; reflexivity; epistemology

\section{Introduction}

Let me explain my title. Sociology as an intellectual discipline was born in late 19th and early 20th century Europe as an attempt to explain the rapid social changes of that era (Giddens 1976; Al-Hardan 2018). Comte, Marx, Spencer, Tönnies, Durkheim, Weber, and the rest had different theories about why and how that change was occurring, but they all thought that something new was afoot in the world. Europe was for them the leading edge of this process. They saw science in general and social science in particular as ways of understanding this new world and of bringing it more fully under human control. They sought to understand the ways that societies shape people: their lives, their actions, and their ideas. Theirs was an Enlightenment project: they believed that scientific knowledge would improve human lives. Weber, more than others, had doubts about this outcome, but all of them thought that the effort was worthwhile.

There was one epistemological problem. Excepting Marx, these early sociologists forgot to locate themselves in the landscape they were describing, and even Marx did not do so consistently. They forgot that they, too, were historical beings, whose social surroundings shape their thinking. Douglas (1975, p. xii) comment that, for Durkheim, the social shaping of knowledge "applied fully to them, the primitives, and only partially to us" was true for all of sociology's founders. Theirs was a colonial world and they stood on top of it, imagining that their superior perspective gave them special responsibility for the well-being of the people they were studying. Their concepts and theories were shaped by their colonial situation. They ignored earlier sociologies, such as that of the great Arab scholar Ibn Khaldūn, because they mistakenly thought that he did not speak to the world's current condition (Spickard 2017a, pp. 135-79). And they suppressed the work of non-White sociologists, such as W. E. B. Du Bois, because that work threatened White Euro-American intellectual hegemony (Morris 2017). 
We no longer tolerate living in that world. Colonialism is dead (though its aftereffects live on), neither Europe nor America is the sole source of intellectual vision, and the Enlightenment project is in tatters. Sociologists who were raised in my White, male, Euro-American, post-Christian, professional-class intellectual milieu have no special insights just because we have mastered sociology's inherited intellectual discourse. We do have insights, but we cannot assume that they are better or more useful than the insights gained from people shaped by other social locations: countries, races, ethnicities, classes, genders, sexualities, religions, and so on. Sociologists raised in these other locales can often see things that people raised like me cannot. Their ideas, however, have also been shaped by their social settings. Some of their concepts and theories, though not all, will improve sociology's ability to understand the complex social world in which we now live. So, I hope, will some of mine.

That is the first point of this article: all knowledge-including sociology—is shaped, though not determined, by the history and culture within which it arose. I explore the consequences of this for the sociology of religion, drawing a parallel with the revolution that has reshaped anthropological ethnography over the last three decades. Ethnographers have learned that they need to include themselves in the social landscape, if they are to represent it accurately. I argue that such descriptive reflexivity needs to be supplemented by a theoretical reflexivity. Sociologists must acknowledge that our standard concepts and theories were produced in a particular historical-cultural milieu. Only by understanding the limitations that the milieu built into those concepts can we improve them and make social-scientific progress.

The second point is related to this, but on an epistemological level. There is a good deal of effort among sociologists to expand the sociological canon on ethical grounds (Al-Hardan 2018). International Sociological Association President Margaret Abraham (2018) address at the latest World Congress of Sociology is a fine example of this, as were many other speeches and commentaries at the event. I shall make a different argument: that the demand for expansion is epistemological just as much as it is ethical. Sociology needs to include diverse voices in order create better knowledge. To remain scientific, we sociologists must transcend our discipline's Euro-American origins. We must embrace theoretical resources from many other standpoints, if we are to improve our understanding of our now-shared world.

\section{Religion and Sociology's Origins}

Let us start with the situation in which the early sociologists created our discipline. They were trying to explain processes that centered on their own societies and they were trying to establish a discipline that saw the world in a new, scientific way. Like all intellectual revolutionaries, they had to distinguish their explanations from competing ideas. Especially in 19th-century France, but also elsewhere, this meant opposing religious understandings of the situation with sociological ones. This involved more than just Comte (1853) postulated progression from theology to metaphysics to science. Reactionary Catholicism worked hard to undermine the French secular state and especially the Third Republic. In response, progressive sociologists treated religion as sociology's conceptual 'Other' (Vásquez 2013). Sociology saw itself as the voice of the future: clear, rational, enlightened, and scientific. This cast religion as a holdover from the past. In the founder's minds, science would ascend while irrational, authoritarian, credulous religion would fade away. The result, Vásquez argued—as did Martin (2005, p. 17) before him-was that secularization theory was built into sociology from the very beginning. The notion that religion is vanishing is a myth, but a powerful one, even now.

I have elsewhere described this myth as part of sociology's "default view" (Spickard 2017a, pp. 21-34). This is a set of taken-for-granted presumptions about religion that shape our scholarship without fully entering our awareness. It includes such notions as religions being primarily matters of belief, embodied in formal organizations, headed by people analogous to clergy, having sacred texts, and so on (Beyer 2006). Sociologists of religion no longer adhere to this as strictly as they did even ten years ago, though the view remains strong, particularly (but not exclusively) in the United States and among quantitative researchers (Smilde and May 2010). Textbooks still uphold the default 
view (Spickard 1994; 2017a, pp. 22-25). Mainstream theory has not significantly departed from the old pattern (Bender et al. 2013), though it is being chewed around the edges by feminists (Neitz 2000; Goldman 2012), scholars of "lived religion" (Hall 1997; Ammerman 2007; McGuire 2008), those investigating religion in 'non-religious' places (Bender 2003; Cadge 2013; Gauthier 2013), and Latin American advocates of "popular religion" as the road to understanding religion's future (Parker 1996, 2018; de la Torre and Martín 2016).

That is why I wrote Alternative Sociologies of Religion (2017a). In it, I discussed the limitations of this default view, but I also presented three non-Western alternatives. If sociology had started in Confucian China, for example, it would have seen the sacred as a relational rather than as an organizational matter. Confucian sociologists of religion would ask a question seldom previously considered in the subdiscipline: Who maintains the sacred relationships in a given instance of religious life? In my book, I show that, for American religious congregations, this is done by the women cooking the church suppers and tending to members' needs (Spickard 2017a, pp. 111-34). This realization puts women at the center of congregational life and men on the periphery-a conclusion that empirical evidence supports as well (Marler 2008; O'Brien 2012; Day 2017). This is the reverse of the Euro-American default view.

I did something similar for sociologies built on the work of Ibn Khaldūn and on insights drawn from Navajo ceremonialism. Ibn Khaldūn explored the ways in which religion and ethnicity both generate "group-feeling", while traditional Navajo religion emphasizes the importance of ritual experiences unfolding in time. These approaches are not special; they just happened to be the ones that I know something about. But the point is special: other historical-cultural situations generate other default views of religion. Each of these default views highlights something different about our subject matter. We learn something important by learning to see religion from other historical-cultural vantage points. It is only by recognizing the limitations of the standard way of thinking and learning to see from other standpoints that we make scientific progress.

The point, again, is that all knowledge, including ours, is shaped by its historical-cultural location. As theorists, we need to become aware of this, to avoid the errors of the past. I spent some time in the book showing how sociology's 19th-century origins primed it to embrace secularization theory. I also showed a connection between market-oriented rational choice theory and the 1980s and 1990s intellectual zeitgeist that saw markets as good explanations for almost everything and saw individual choice as constituent of all aspects of life. I won't go into these here.

Instead, I want to explore a deeper issue. I want to explore the necessity of and the implications of sociologists of religion taking our own historical-cultural locations into account in our theorizing-from non-dominant locations as much as from dominant ones. Why do we need to remember where we stand when we survey the social world? Why should we focus on how that standpoint shapes our thinking? What can we gain from building that realization into our theories?

I am speaking, here, of a theoretical parallel to the revolution that has reshaped anthropological ethnography over the last three decades (Clifford and Marcus 1986; Behar and Gordon 1995; Dawson et al. 1997; Spickard et al. 2002). Ethnographers used to present themselves as having a God's-eye view of the social scenes they were describing, but they no longer do so. They have long acknowledged that their data come from their ability to embed themselves in scenes that are not their own, but they now acknowledge the need to make explicit what their own backgrounds prevent them from seeing. They need to show their readers how the ideas they bring with them into the field often prevent them from understanding aspects of the scenes they are trying to portray.

The young Isaac Newton wrote in his notebooks about sticking a large needle in his eye, to learn how that eye systematically distorted his vision (Breen 2014). I am not asking us to do anything so painful. Yet learning to see the limits of our own seeing is crucial for making progress as a field. 


\section{The Ethnographic Revolution}

What was this ethnographic revolution? How is what anthropological ethnographers do today different from what they did when I was trained a couple of generations ago?

My teachers and my teachers' teachers were trained to visit far-away peoples, learn their languages, find out how they saw the world, how they acted in it, and how they maintained a sense of meaning. Then they were supposed to report back to their readers or superiors about what they learned. The results are fascinating. Books like Argonauts of the Western Pacific (Malinowski 1922), We, the Tikopia (Firth 1936), Nuer Religion (Evans-Pritchard 1956), Divinity and Experience (Lienhardt 1961), Navaho Witchcraft (Kluckholn 1944) and others carry us to unaccustomed worlds. These were good books, but they were embedded in a colonial power structure that remained hidden from their readers' view (Wolf 1982). Evans-Pritchard, for example, was sent to the Sudan by the British Colonial Office to find out about Nuer politics. He so mastered their segmentary political system that he organized Nuer raids against Italians troops in neighboring Ethiopia in early World War II (Geertz 1988). Yet he did not write about that success. Instead, he wrote about the Nuer as if he were invisible, a fly on the wall, not really there.

A few decades prior, the American ethnographer Frank Cushing installed himself without permission in the Governor's living-room at Zuni Pueblo and wandered into secret ceremonies uninvited (McFeely 2001). The Zuni did not want to risk annoying his employers at the Bureau of Indian Affairs, so they did not throw him out. They turned the tables, however, by sending their own ethnographer to Washington DC to figure out how to keep the Americans at bay. We'wha, a cross-dressing berdache, was fêted for a year as a "Zuni princess". We don't know what secrets she took back to New Mexico with her, but they surely helped the Zuni maintain some independence.

Most, though not all, of these early ethnographers retained a colonial outlook on the people they were observing. They thought that "We", the advanced people, study "Them", the backward people, either to control them or to save their knowledge for posterity as their cultures fade away. Sociological ethnography began slightly differently. In the U.S., the Chicago School and the Settlement House movement were projects of an educated elite who used ethnography to study immigrants and lower class people whom the elite wanted to teach middle-class American behavior (Thomas and Znaniecki 1996; Whyte 1943).

Contemporary sociology of religion has inherited this approach. Our typical ethnographies try to show what role religion plays in lower-status people's lives. Think about the way that our discipline frames theories: if the tables were turned, would we be claiming that the elite's religions are mere "compensators" for the things they can't have in life (Stark and Bainbridge 1980)? Yet we entertain this about poor and working-class people's religions, and ethnic minorities', too. Too many of our studies still explain such religion as "the sigh of the oppressed creature" (Marx 1844). Few of us would accept this conclusion, were lower-status people to investigate us.

Such dynamics operate across all the lines dividing our increasingly globalized society: class, race, ethnicity, gender, sexuality, level of development, education, place in the world colonial and neo-colonial system, and so on. Scholars of all stripes need to understand our own position in these systems at least as much as Newton had to understand how his eye bent light. If we don't know the distortions, we cannot correct for them. We cannot really see the world we are investigating.

Such thinking brought forth "the reflexive turn" in contemporary ethnography. A host of new ethnographers wrote themselves into their stories, so we could better understand their fieldwork and grasp the dynamics of the social scenes they were recording (Hamabata 1990; Behar 1996). Brown (1991, 2002), for example, wrote herself into her ethnographic biography of Alourdes, a Vodou priestess living in Brooklyn, New York. Brown used her presence to highlight her own cultural missteps and to remind readers that Alourdes was the expert on Vodou, not she. Tweed $(1997,2002)$ wrote of his ambivalent experiences investigating a Cuban-American Marian shrine in Miami. His natal (but abandoned) Catholicism gave him access to the shrine keepers, but it also led them to try to reconvert him. This 
challenged him as a scholar. It made him realize that the people we study have agendas, too. He told us about this, so we, his readers, would know the limits of his seeing.

We need to know such things, and not just because they remind us that ethnography is a very personal data-gathering method. They also remind us that we, as readers, bring our historical-cultural prejudices to the texts. We can misread those texts, destructively. Heelas and Woodhead (2005) and Albrow (1997) have each written about American culture's fascination with Pentecostal snake-handling, which many observers see as dark, mysterious, benighted, and cruel. Both these scholars show how this image of Pentecostal mountain people says more about educated people's voyeuristic fantasies than it does about the 'snake-handlers' themselves.

That's the point. Each of us brings our own historical and cultural assumptions to our investigations. If we are unaware of them, they will color our findings. We will, as do so many sociologists of religion, look for religion in churches, synagogues, mosques, temples, gurdwaras, and other formal places and ignore it everywhere else. We will ask people about their religious beliefs but not about their relationships. We will ask them how religions shape their moral lives. These are all good questions, but they retain a partial vision of religious life.

We can no longer treat Euro-American Christianity as the model by which we understand all religions. We live in a different world than did our sociological forebears. We need to explore it-and theorize about it-differently than we have before.

\section{Our Present Situation}

What is our historical-cultural situation? It is not that of late 19th-century France, nor that of mid-20th-century America, though both still heavily influence our thinking. What does our contemporary situation prime us to see about religion that we might not have seen before? Three factors stand out to me, though there may well be others.

The first of these is globalization. Where once our lives revolved around our local communities and most of us produced goods and services for the local market, now we have ties to people around the world. These ties involve much more than the ubiquity of telephones and of the Internet. They involve more than the complex network of trade relations that bring bananas, coffee, and tea to our breakfast tables. They even involve more than the interconnected financial markets that, on the one hand, let us use our credit cards in Timbuktu but, on the other hand, produce worldwide financial panics that threaten to bring whole economies to their knees. ${ }^{1}$ All these are important, but they do not exhaust the connections we now have with one another.

The fact is, our current global system is shaped by great inequality, specifically by the aftermath of centuries of Euro-American colonialism. Europe and North America, plus Japan, China, Australia, and a few others, have much more influence than do most places. This makes every intellectual act different than would be the case if these power relations did not exist. Those of us who live in the metropole can theorize as if the world were "flat", to use Friedman (2006) rather ideological metaphor. Those theorizing from other places cannot ignore the metaphoric hills and mountains that perpetuate social inequality (de Blij 2009). Opportunity is decidedly not available to everyone. Power divides us wherever we turn.

For scholars, some of those hills and mountains come from differential access to research funding. May and Smilde (2018) recently sampled forty years of articles on religion in top U.S. sociology journals and found that an increasing percentage depended on funding, especially from non-public sources. This makes it difficult for scholars from outside the metropole to publish in such journals, as they lack the right financial connections. As a result, scholars from the Global North dominate sociological research and those from the Global South are ignored. To take one small example, sociologists around

1 Think of the worldwide market-quakes radiating from Mexico (1994), East Asia (1997), Russia (1998), the U.S. (tech stocks in 2001; hedge funds in 2005; sub-prime mortgages in 2007-2008), and Europe (PIIGS debt crisis 2009-2013). 
the world are familiar with North American scholars who have written on Latin American popular religion, such as Smith (1996) and Ammerman (2007), but are far less familiar with the many Latin American scholars who have done so too (Antoniazzi et al. 1994; Mariz and das Dores Campos Machado 1998; López 2000; de Carlos 2004; Orellana 2008; Mansilla 2009).

People today are thus both linked and divided. Our different historical-cultural locations make us see these links and divisions differently. We cannot understand religion's place in the world without reaching beyond our own standpoints.

A second crucial factor is identity. Identities come in different varieties than they used to. I wrote in my book that

Only men have the privilege of imagining that they lack gender. Only Whites have the privilege of imagining that they lack race. [And] only heterosexuals have the privilege of ignoring peoples' varied and complex sexualities. (Spickard 2017a, p. 247)

Let me add that only people who live in relative wealth can imagine that poverty does not matter. Only people who live in stable nations can imagine that there are still fixed and safe nationalities. Only people who have the freedom to choose their religions can imagine that religion is a matter of private choice.

These identities are not mutually exclusive. The term 'intersectionality' underlines the fact that the various forms of social stratification I have just listed do not exist separately from each other but are interwoven in real people's lives (McCall 2005). This makes the investigation of conceptual blinders an empirical matter. For example, I have a colleague who looks a lot like me, but you cannot understand the way he thinks unless you know that he went to school in an African American neighborhood and attended an Asian evangelical church for over 30 years. His historical-cultural background is different than his attributed identity would seem.

Today, however, any of these attributed identities can become a master identity, even against a person's will. The Croatian writer Drakulić (1993) described how she had always defined herself by her education, profession, gender, and personality - until the Croatian-Serbian war stripped her of everything but being a Croat. Religion can do the same thing; think of the 1975-1990 civil war in Lebanon, the recent rise of ISIS in the Middle East, and anti-Muslim violence in Myanmar and Germany today. Identity is a key factor in our current world, but it is imposed as often as it is freely chosen.

If our theories cannot see this, then we are standing in the wrong place.

If our theories forget to think about the complexities of genders, races, sexualities, class standings, nationalisms, and different peoples' abilities to choose-along with their intersections-then we are forgetting the real world that we live in. Theories about a fanciful world are just that: fantasies. This is not good enough.

Yet there is a third factor, as well. I had originally subtitled my book "Towards a World-Conscious Sociology of Religion" because I think we are on the cusp of an era in which consciousness of the world as a single place is possible. This is not some Pollyannaish moment, filled with sparkly My Little Ponies and everyone singing Kumbaya. (I apologize for the Americanisms, but they express this very well). Nor is it because we have that famous picture of a blue planet hanging in the starry firmament (Apollo 1968) and French President Macron reminding the U.S. Congress that "We have no Planet B" (CNN 2018).

Globalization is not just a matter of material connections; it is also a matter of consciousness (Albrow 1997). Once we understand that (for example) the American and European appetite for palm oil leads to clear-cutting rainforests in Borneo, which in turn increases the carbon load on the atmosphere (Rosenthal 2007), we think differently than we did before. The same happens when we learn that donating used clothing to charities in the U.K. harms the local textile industry in Kenya, where $75 \%$ of such donations end up (Kubania 2015). In such instances, we see that our local standpoint misleads us. We learn that we need to see from other standpoints, if we want to see how our global system works. 
This brings us back to the sociology of religion. Our discipline's currently dominant theories were created in Europe and America to understand developments in Euro-American religion. We need to recognize their standpoint-based partiality. In our interconnected world, it seems quaint to think that life will improve as 'bad old authoritarian religion' fades away or at least retreats to the private sphere (Vásquez 2013). Equally quaint is the notion that progress comes when we free up religious markets, as the rational-choice theorists wanted us to believe (Stark and Finke 2000). Nor is the promise of increased religious individualism (Heelas and Woodhead 2005) a panacea, at least because such religion erases the possibility of social critique (Spickard 2017b)—something that an interconnected, risk-filled world sorely needs.

Each of these theories was plausible when the world was less connected and those of us living in the Global North could imagine that others' experiences of the world were much like our own. That is no longer the case. Others' experiences are not just like our own, and people in other social locations see things that we cannot. Yet we all share the same complex world. If we are to understand that world - the point of our science-all of us need to recognize that our visions are partial. No matter where we stand, we are confronted with the conceptual limitations that our own social locations create for us. Transcending those limitations is the intellectual task of our time.

Reflexive theorizing calls for us to grip this tightly. It asks us to remember our own location when we theorize. It asks us to recognize the limits of our own vision. It asks us to remember that different people have different amounts of power, including the financial power noted above. Yet it requires us to reach across our divisions, so that we can learn what people with different powers, with other identities, and from other historical-cultural locations see about our common world.

This could not have happened in a fully colonial era. Said (1978), Fanon (1963), Memmi (1967), Geertz (1988), Trinh (1989), and others have ably shown us how colonialism made social-scientific knowledge a tool of empire. Their post-colonial theorizing was a slap against that empire and the social scientists whose work supported it. In effect, they said it was time for Western intellectuals to obey the title of American Indian activist Deloria (1970) book: We Talk, You Listen. Euro-American intellectuals have a lot of listening to do, before we understand what the world looks like from other historical-cultural locations than our own.

Listening, however, is not the end of the road. Every location has its blind spots-including the post-colonialists' (Spickard 2017a, pp. 225-41). Every location lets us see some things but hides others. There is no God's eye view of the global world that we share. If we want to understand that world, then we have to lean across our differences and share our insights. Sprague (2005), who understands social-scientific epistemology as well as anyone I have encountered, writes about the strength of standpoint theories. She tells us that all humans have standpoints, but we also have the ability to imagine the world from other people's standpoints. We can use these to correct our own.

\section{The Ethics and Epistemologies of Reflexive Theorizing}

At this point, a perfectly wise sociologist of religion would describe for you a perfectly reflexive theory about religion's place in the contemporary world. She would tell you what is happening to religion and why that happening looks different, depending on where we stand.

For example: where a statistical sociologist might tie membership declines in American and European churches to a loss of religious belief (Bruce 2002), a feminist sociologist might trace this to changing women's roles: increased women's employment lowers how much they can volunteer to sustain local congregations (Marler 2008; Day 2017), leading those congregations to decline. A Confucian sociologist might elaborate this, noting that women's socially assigned role in maintaining interpersonal relationships is central to American and British religious life. Their action is the $l i$ that generates the de that makes congregations possible (Spickard 2017a, pp. 111-34) A Khaldūnian sociologist might take a different tack by asking where and when religion becomes a locus of group identity, as opposed to ethnicity, class, nation, or other markers (Spickard 2017a, pp. 159-80). A sociologist sensitive to poor people might trace the ways that their religious engagements helps 
them cope with life in a world stacked against them (Smilde 2007). Each of these would illuminate part of the picture. Other standpoints would make other contributions.

The problem is, I am not a perfectly wise sociologist of religion. I cannot give you such a sum-it-up picture of religion in the contemporary world.

I can, however, make some comments on the epistemological and ethical implication of the picture I have been painting. To remind you: that picture contains three elements.

- First, we all see the world through lenses shaped by our historical-cultural situations.

- Second, each of those lenses has a partial but perspectivally accurate view.

- Third, we live in a hilly, unequal, but globalizing world, where we can, if we will, communicate across our partial viewpoints and see our own partiality.

There are a lot of barriers to that communication, but it is at least possible. The question is, how can we encourage that communication to improve our discipline's understanding of the world we share?

I need to introduce a concept here, one well-known in Kantian metaphysics and in certain varieties of the philosophy of science. This is the notion of a "regulative ideal". Put simply, a regulative ideal is an abstract idea that makes practical activity possible. It does not, itself, constitute knowledge, but it regulates thought so that a particular action ensues (Kant 1965, A180/B222)

Let's imagine a social scientist who studies religions. Social scientists share an ideal that regulates all their scientific activity: it is the ideal that a scientist is supposed to get things right. As scientists, we come up with hypotheses, then we find data to test them. What are we supposed to do if the data tell us that our hypothesis is wrong? We throw away the hypothesis and seek a better one. This is so simple that it is in our beginning textbooks. Yet it puts us in rather deep epistemological waters.

The problem is, what count as data and proof shift from time to time and place to place, depending on what our scientific community will accept. When I entered this profession, most sociologists of religion would only accept numbers as data: demographics, survey research, and so on. I was told in no uncertain terms that my ethnographic work was not sociology, no matter how rigorous my fieldwork had been. That has changed. Sociologists of religion now see the worth of qualitative data because it, together with numeric data, gives us a 'better' picture of religion than numeric data alone. This is progress.

Yet notice the intellectual structure of this statement. 'Progress' means that we have absorbed another way of seeing the world because we now agree that it produces a picture that is 'more right' than the picture we held before. If we did not have that ideal of 'getting things right', we would not be able to speak of progress at all. Scientific progress depends on the abstract notion that we can improve our understanding. This regulative ideal lets us improve our accounts of the world—not just individually, but as a scientific community.

Charles Sanders Peirce put this abstractly, using the term 'truth' in place of the term I have used here: 'getting things right'. He pointed out that 'scientific truth' is the result of an eschatological process. He wrote that: "Truth is that concordance of abstract statement with the ideal limit toward which endless investigation would tend to bring scientific belief." ${ }^{2}$ He saw the scientific enterprise as a communal activity, in which scientists read and critiqued each other's work, repeat each other's experiments, and gradually—collectively—come to understand the world better than they had before. Self-critical striving for an ever-better picture of the world lets scientists say with certainty that current views improve on the past. They can be just as certain, however, that their continued effort to get things right will overthrow current understandings.

As sociologists, we are engaged in the same endeavor. What is required of us, if we are to improve our understanding of religion in the contemporary world?

2 Quoted by Feibelman (1969, p. 212). 


\section{What Is to Be Done?}

There are, I think, three things that we must do. These are not moral judgments, or at least not only moral judgments; they are also scientific and epistemological ones. We must do these things or else we will be unable to improve sociology's knowledge of our subject matter.

My first proposition is that people who are privileged must listen to the insights of those who are not.

We are long past the day when we could listen only to White, male, Euro-American, professional class voices to tell us what is happening to religion. These voices have insights, but they do not see the whole picture. They-and I include myself-are privileged enough to be able to forget that their vision is partial. In our present, hilly, unequal world, they are, relatively speaking, at the center. If we want our discipline to progress, sociologists must listen to the voices from the margins, so as to correct our current misunderstandings. Our discipline will not make theoretical progress unless we all communicate and combine our respective insights. Those at the center already dominate our discipline's communications; they do not need to work to make their voices heard. Thus, they need to make explicit room for marginal voices. Those voices have something to contribute as well.

My second proposition is that we must analyze the socio-political situation in which both marginal voices and central voices live.

Intellectual life does not exist in a vacuum; it is shaped by larger world events. Secularization theory absorbed the prejudices of its day, just as rational-choice theory absorbed the politics of neoliberalism. The same could easily happen today. Keeping a weather-eye on the dynamics of our own era is the only way that we can track the forces shaping us. Again, this is a scientific/epistemological issue rather than just a moral one. Ignoring such factors practically guarantees that we will get the picture wrong.

The third proposition is a bit different. If what I have been arguing is correct, our effort to create a scientific sociology of religion depends on free communication between people across cultural, national, racial, ethnic, class, gender, and other divides. We need everyone's insights if we to progress. That requires us to defend each other's participation in the world conversation.

My third proposition flows from this: We must protect each other's independent intellectual inquiry.

We must do so, not just in the name of humanity, though that ought to be enough; we must do it in the name of science. If we do not, if oppression, violence, denial of resources, or silencing makes us lose our colleagues' contributions, then our science suffers. Protecting free intellectual inquiry is an epistemological matter, not just an ethical one; without it, scientific progress is impossible. This point is at the heart of my contribution today.

Our globalized world ties us together in webs of social and economic interdependence. Our work as scientists does so intellectually as well. World inequities threaten our conversation partnerspolitically, economically, socially, and militarily. People without power are, as our late colleague Maduro (2004, p. 232) reminded us, "consistently threatened, busted, bombed, or trampled by the this-worldly powers and principalities".

Maduro (2014, p. 45) also reminded us that "As intellectuals, we brandish a special kind of power." It matters how we use that power: "with whom, for whom, for what?" He saw this primarily as an ethical issue, but I submit it is also a scientific and epistemological one. Only the privileged can ignore the inequality and violence in our world. Ignoring inequality, violence, and the world's other ills means that we fail to see religion (and everything else) clearly from standpoints other than our own. It makes us forget that our own views are partial ones, and we mistake the part for the whole. We then do bad science.

Reflexive theorizing in the sociology of religion requires us to see the world as it is, and to seek the insights of those who encounter the world through multiple historical-cultural lenses. It calls us to be one world community.

Fortunately, there are now international scholarly organizations-the International Sociological Association among them-dedicated to all three of these tasks. Our Research Committee for the Sociology of Religion has fostered and will continue to foster the voices from the margins from which 
we have so much to learn. It has analyzed and will continue to analyze the socio-political situation in which we all live. And it has defended and will continue to defend the right of sociologists everywhere to describe our world, free from suppression, violence, and fear.

We have not done enough. There is more to do, but at least we are walking the right road. Our science depends on our continuing to do so.

Funding: This research received no external funding.

Acknowledgments: This article originated as the Presidential Address to the International Sociological Association's Research Committee on the Sociology of Religion at the XIX ${ }^{\text {th }}$ World Congress of Sociology, July 2018, Toronto, Canada. The author thanks Anna Halafoff, Eloísa Martín, Edward Tiryakian, Roberto Blancarte, Julia Martinez-Ariño, and this journal's anonymous reviewers for critical comments that strengthened this paper.

Conflicts of Interest: The author declares no conflict of interest.

\section{References}

Abraham, Margaret. 2018. Presidential Address. Power, Violence and Justice: Reflections, Responses and Responsibilities. Speech. Paper presented at the World Congress of Sociology, Toronto, ON, Canada, July 15. Al-Hardan, Anaheed. 2018. The Sociological Canon Reconfigured: Empire, Colonial Critique, and Contemporary Sociology. International Sociology 33: 545-57. [CrossRef]

Albrow, Martin. 1997. The Global Age: State and Society beyond Modernity. Stanford: Stanford University Press.

Ammerman, Nancy T., ed. 2007. Everyday Religion: Observing Modern Religious Lives. New York: Oxford University Press.

Antoniazzi, Alberto, Avelino Grassi, Cecilia Loreto Mariz, and Ingrid Sarti, eds. 1994. Nem Anjos Nem Demônios: Interpretações Sociológicas Do Pentecostalismo. Petrópolis: Ed. Vozes.

Apollo, Astronauts. 1968. The Blue Marble. NASA Image and Video Library. Available online: https://go.nasa. gov/2NI3G77 (accessed on 3 September 2018).

Behar, Ruth. 1996. The Vulnerable Observer: Anthropology That Breaks Your Heart. Boston: Beacon Press.

Behar, Ruth, and Deborah Gordon, eds. 1995. Women Writing Culture. Berkeley: University of California Press.

Bender, Courtney. 2003. Heaven's Kitchen: Living Religion at God's Love We Deliver. Chicago: University of Chicago Press.

Bender, Courtney, Wendy Cadge, Peggy Levitt, and David Smilde. 2013. Religion on the Edge: De-Centering and Re-Centering the Sociology of Religion. New York: Oxford University Press.

Beyer, Peter F. 2006. Religions in Global Society. New York: Routledge.

Birckhead, Jim. 1997. Reading "Snake Handling": Critical Reflections. In Anthropology of Religion: A Handbook. Edited by Stephen D. Glazier. Westport: Greenwood Press, pp. 19-84.

Breen, Benjamin. 2014. Newton's Needle: On Scientific Self-Experimentation. Pacific Standard. Available online: https:/ / goo.gl/yWC2nz (accessed on 9 May 2018).

Brown, Karen McCarthy. 1991. Mama Lola: A Vodou Priestess in Brooklyn. Berkeley: University of California Press.

Brown, Karen McCarthy. 2002. Writing About 'the Other', Revisited. In Personal Knowledge and Beyond: Reshaping the Ethnography of Religion. New York: New York University Press, pp. 127-33.

Bruce, Steve. 2002. God Is Dead: Secularization in the West. Oxford: Blackwell.

Cadge, Wendy. 2013. Paging God: Religion in the Halls of Medicine. Chicago: University of Chicago Press.

Clifford, James, and George E. Marcus, eds. 1986. Writing Culture: The Poetics and Politics of Ethnography. Berkeley: University of California Press.

CNN. 2018. Macron Warns Us Congress: There's No Planet B. CNN, April 25. Available online: https://cnn.it/ 2PMmdQj (accessed on 18 September 2018).

Comte, Auigust. 1853. The Positive Philosophy of Auguste Comte. Translated by Harriet Martineau. London: Chapman.

Dawson, Andrew, Allison James, and Jenny Hockey, eds. 1997. After Writing Culture: Epistemology and Praxis in Contemporary Anthropology. New York: Routledge.

Day, Abby. 2017. The Religious Lives of Older Laywomen: The Final Active Anglican Generation. Oxford: Oxford University Press. 
de Blij, Harm. 2009. The Power of Place: Geography, Destiny, and Globalization's Rough Landscape. New York: Oxford University Press.

de Carlos, Garma Navarro. 2004. Buscando El Espíritu: Pentecostalismo En Iztapalapa Y La Ciudad De Mexico. México City: Universidad Autónoma Metropolitana, Iztapalapa.

de la Torre, Renée, and Eloísa Martín. 2016. Religious Studies in Latin America. Annual Review of Sociology 42: 473-92. [CrossRef]

Deloria, Vine, Jr. 1970. We Talk, You Listen: New Tribes, New Turf. Lincoln: Unversity of Nebraska Press.

Douglas, Mary. 1975. Implicit Meanings: Essays in Anthropology. London: Routledge \& Kegan Paul.

Drakulić, Slavenka. 1993. Overcome by Nationhood. In The Balkan Express: Fragments from the Other Side of War. New York: W. W. Norton, pp. 43-52.

Evans-Pritchard, Edward E. 1956. Nuer Religion. New York: Oxford University Press.

Fanon, Frantz. 1963. The Wretched of the Earth. Translated by Constance Farrington. New York: Ballentine Books.

Feibelman, James K. 1969. An Introduction to the Philosophy of Charles S. Peirce. Cambridge: MIT Press.

Firth, Raymond W. 1936. We, the Tikopia; a Sociological Study of Kinship in Primitive Polynesia. London: G. Allen \& Unwin.

Friedman, Thomas L. 2006. The World Is Flat: A Brief History of the Twenty-First Century. New York: Farrar, Strauss, and Giroux.

Gauthier, François. 2013. The Enchantments of Consumer Capitalism: Beyond Belief at the Burning Man Festival. In Religion in Consumer Society: Brands, Consumers, and Markets. Edited by François Gauthier and Tuomas Martikainen. Farnham: Ashgate Publishers, pp. 143-59.

Geertz, Clifford. 1988. Works and Lives: The Anthropologist as Author. Stanford: Stanford University Press.

Giddens, Anthony. 1976. Classical Social Theory and the Origins of Modern Sociology. American Journal of Sociology 81: 703-29. [CrossRef]

Goldman, Marion S. 2012. The American Soul Rush: Esalen and the Rise of Spiritual Privilege. New York: NYU Press.

Hall, David D., ed. 1997. Lived Religion: Toward a History of Practice. Princeton: Princeton University Press.

Hamabata, Mathews Masayuku. 1990. Crested Kimono: Power and Love in the Japanese Business Family. Ithaca: Cornell University Press.

Heelas, Paul, and Linda Woodhead. 2005. The Spiritual Revolution: Why Religion Is Giving Way to Spirituality. Oxford: Basil Blackwell.

Kant, Immanuel. 1965. Critique of Pure Reason. Translated by Norman Kemp Smith. New York: St. Martin's Press. First published 1781.

Kluckholn, Clyde. 1944. Navaho Witchcraft. Cambridge: Peabody Museum.

Kubania, Jacqueline. 2015. How Second-Hand Clothing Donations Are Creating a Dilemma for Kenya. The Guardian, July 6. Available online: http:/ / bit.ly/2xvHG8Q (accessed on 18 September 2018).

Lienhardt, Godfrey. 1961. Divinity and Experience: The Religion of the Dinka. Oxford: Clarendon Press.

López, Darío. 2000. Pentecostalismo Y Transformación Social. Buenos Aires: Kairos.

Maduro, Otto. 2004. 'Religion' under Imperial Duress? Post-Colonial Reflections and Proposals. Review of Religious Research 45: 221-34. [CrossRef]

Maduro, Otto. 2014. American Academy of Religion 2012 Presidential Address: Migrants' Religions under Imperial Duress: Reflections on Epistemology, Ethics and Politics in the Study of the Religious 'Stranger'. Journal of the American Academy of Religion 82: 35-46. [CrossRef]

Malinowski, Bronislaw. 1922. Argonauts of the Western Pacific. New York: E.P. Dutton.

Mansilla, Miguel Ángel. 2009. La Cruz Y La Esperanza: La Cultura Del Pentecostalismo Chileno En La Primera Mitad Del Siglo XX. Santiago: Editorial Universidad Bolivariana.

Mariz, Cecília Loreto, and Maria das Dores Campos Machado. 1998. Changements Récents Dans Le Champ Religieux Brésilien. Social Compass 45: 359-78. [CrossRef]

Marler, Penny Long. 2008. Religious Change in the West: Watch the Women. In Women and Religion in the West: Challenging Secularization. Aldershot: Ashgate, pp. 23-56.

Martin, David A. 2005. On Secularization: Towards a Revised General Theory. London: Ashgate.

Marx, Karl. 1844. A Contribution to the Critique of Hegel's Philosophy of Right: Introduction. Deutsch-Französische Jahrbücher. Available online: https://goo.gl/8HnKT3 (accessed on 18 September 2017). 
May, Matthew, and David Smilde. 2018. Does Funding Impact Our Research? Causality, Normativity, and Diversity in 40 Years of U.S. Sociology of Religion. Journal for the Scientific Study of Religion 57: 432-49. [CrossRef]

McCall, Leslie. 2005. The Complexity of Intersectionality. Signs: Journal of Women in Culture and Society 30: 1771-800. [CrossRef]

McFeely, Eliza. 2001. Zuni and the American Imagination. New York: Hill and Wang.

McGuire, Meredith B. 2008. Lived Religion: Faith and Practice in Everyday Life. New York: Oxford University Press. Memmi, Albert. 1967. The Colonizer and the Colonized. Translated by Howard Greenfield. Boston: Beacon Press.

Morris, Aldon D. 2017. The Scholar Denied: W. E. B. Du Bois and the Birth of Modern Sociology. Berkeley: University of California Press.

Neitz, Mary Jo. 2000. Queering the Dragonfest: Changing Sexualities in a Post-Patriarchal Religion. Sociology of Religion 61: 369-91. [CrossRef]

O’Brien, Nancy Frazier. 2012. Researcher's Advice to Pastors: Spend More Time on Church Suppers. Available online: http:/ / bit.ly/2LB1f6d (accessed on 25 September 2018).

Orellana, Luis. 2008. El Fuego Y La Nieve: Historia Del Movimiento Pentecostal En Chile 1909-1932. Concepción: Centro Evangélico de Estudios Pentecostales.

Orsi, Robert A. 2005. Snakes Alive: Religious Studies between Heaven and Earth. In Between Heaven and Earth: The Religious Worlds People Make and the Scholars Who Study Them. Edited by Robert A. Orsi. Princeton: Princeton University Press, pp. 177-204.

Parker, Cristián G. 1996. Popular Religion and Modernization in Latin America: A Different Logic. Maryknoll: Orbis Books.

Parker, Cristián G. 2018. Popular Religions and Multiple Modernities: A Non-Western Perspective. In Culture and Identity. Edited by Wilfred April. London: IntechOpen, pp. 91-112.

Rosenthal, Elisabeth. 2007. Once a Dream Fuel, Palm Oil May Be an Eco-Nightmare. New York Times, January 31. Available online: https:/ /nyti.ms / 2xvB4Y4 (accessed on 18 September 2018).

Said, Edward W. 1978. Orientalism. New York: Pantheon.

Smilde, David. 2007. Reason to Believe: Cultural Agency in Latin American Evangelicalism. Berkeley: University of California Press.

Smilde, David A., and Matthew May. 2010. The Emerging Strong Program in the Sociology of Religion: A Critical Engagement. Brooklyn: Social Science Research Council.

Smith, Christian S. 1996. Disruptive Religion: The Force of Faith in Social-Movement Activism. New York: Routledge. Spickard, James V. 1994. Texts and Contexts: Recent Trends in the Sociology of Religion as Reflected in American Textbooks. Social Compass 41: 313-328.

Spickard, James V. 2017a. Alternative Sociologies of Religion: Through Non-Western Eyes. New York: NYU Press.

Spickard, James V. 2017b. Où est passé la «voix morale» de la religion? La troisième vague du marché et; a Montée de; 'ideology néoliberale. Translated by François Gauthier. Revue du MAUSS 49: 148-66.

Spickard, James V., J. Shawn Landres, and Meredith B. McGuire, eds. 2002. Personal Knowledge and Beyond: Reshaping the Ethnography of Religion. New York: NYU Press.

Spivak, Gayatri Chakravorty. 1988. Can the Subaltern Speak? In Marxism and the Interpretation of Culture. Edited by Cary Nelson and Lawrence Grossberg. Champaign: University of Illinois Press, pp. 271-316.

Sprague, Joey. 2005. Feminist Methodologies for Critical Researchers: Bridging Differences. Walnut Creek: Altamira.

Stark, Rodney, and William Sims Bainbridge. 1980. Towards a Theory of Religion. Journal for the Scientific Study of Religion 19: 114-28. [CrossRef]

Stark, Rodney, and Roger Finke. 2000. Acts of Faith: Explaining the Human Side of Religion. Berkeley: University of California Press.

Thomas, William Isaac, and Florian Znaniecki. 1996. The Polish Peasant in Europe and America: A Classic Work in Immigration History. Edited by Eli Zaretsky. Urbana: University of Illinois Press.

Trinh, T. Minh-ha. 1989. Woman, Native, Other: Writing Poscoloniality and Feminism. Bloomington: Indiana University Press.

Tweed, Thomas A. 1997. Our Lady of the Exile: Diasporic Religion at a Cuban Catholic Shrine in Miami. Oxford: Oxford University Press.

Tweed, Thomas A. 2002. Between the Living and the Dead: Fieldwork, History, and the Interpreter's Position. In Personal Knowledge and Beyond: Reshaping the Ethnography of Religion. New York: NYU Press, pp. 63-74. 
Vásquez, Manuel A. 2013. Grappling with the Legacy of Modernity: Implications for the Sociology of Religion. In Religion on the Edge: De-Centering and Re-Centering the Sociology of Religion. New York: Oxford Univ Press, pp. 23-42.

Whyte, William Foote. 1943. Street Corner Society: The Social Structure of an Italian Slum. Chicago: University of Chicago Press.

Wolf, Eric R. 1982. Europe and the People without History. Berkeley: University of California Press.

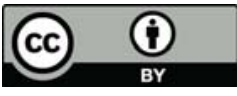

(C) 2018 by the author. Licensee MDPI, Basel, Switzerland. This article is an open access article distributed under the terms and conditions of the Creative Commons Attribution (CC BY) license (http:/ / creativecommons.org/licenses/by/4.0/). 

Article

\title{
Curating Violence: Reflecting on Race and Religion in Campaigns for Decolonizing the University in South Africa
}

\author{
Federico Settler \\ School of Religion, Philosophy and Classics, University of KwaZulu-Natal, Pietermaritzburg 3201, South Africa; \\ settler@ukzn.ac.za
}

Received: 31 March 2019; Accepted: 1 May 2019; Published: 8 May 2019

\begin{abstract}
During 2015 and 2016, staff and students at university campuses across South Africa embarked on two campaigns for decolonizing higher education, but the efforts were met with various forms of violent repression and rationalization of violence by state and private security services. In the face of the securatization of university campuses countrywide, ordinary mediums of teaching and learning proved inadequate for helping students reflect on their social reality, and similarly, public gatherings for socio-political deliberation and commentary became irregular because of the policing and surveillance of student protest action. By reflecting on the curation of three memorials and performances about seemingly racialized violence in this context, this article interrogates the meaning and the relation to the aesthetic, as well as the commentary on the context within which it is produced. Drawing on the work of Mbembe, Fanon, and Spivak as theoretical interlocutors with respect to how I understand violence, this article reflects on how three interdisciplinary curatorial events raise pedagogical challenges and opportunities for critical reflection in a context of repression. It was precisely through this interdisciplinary effort that the black body, violence, and context aligned to produce a public pedagogy on physical and representational violence. The three curatorial moments allowed for meaningful reflection on violence, resistance, religion, and the racialized self that not only drew attention to the artifacts and the performances but deliberately opened possibilities for a kind of public classroom where the discussion, articulation, and critique of violence is possible and productive.
\end{abstract}

Keywords: race; religion; violence; South Africa; decoloniality

\section{Introduction}

On 9 April 2015, the statue of Cecil John Rhodes was removed from the public area where it stood in the grounds of the University of Cape Town. This material and symbolic act was the culmination of a period of public deliberation and protest action by students on the campus. This moment also marked the beginning of a wider campaign of deliberation about the role of the public university in the postcolony and, in particular, the ways that black students and faculty find these institutions alienating. In fact, that language used by a student leader, Chumani Maxwele-who in an act of public protest threw a bucket of human faeces over the figure of Cecil John Rhodes a month previously-spoke to violence directed towards black students as they sought to make the university their home. Maxwele stated that "... there is a certain kind of violence that is done to a black person when everything around you reinforces the idea that this is not your world, and you are not welcome." This kind of symbolic violence (Bourdieu [1980] 1990, 2001; Fanon 1967), produced a discontent among South African students from university campuses across the country and gave birth to the largest public interest campaign in the country's democratic era. While students at other campuses had engaged in similar regional protests for several years already, the student campaign known as \#Rhodesmustfall 
and \#Feesmustfall, were, respectively, oriented to address the transformation of the institutional cultures of universities perceived to be white-normative and to facilitate access to higher education for black students.

The protest actions from students assumed various forms during the two periods of academic disruptions that took place between early 2015 and the end of 2016 and drew a wide range of responses from supporters and critics (Ndelu et al. 2017). This period was also marked by the unexpected mass mobilization by activists through the use of social media, as well as transnational solidarity action reminiscent of the occupy movement, with explicit links to \#blacklivesmatter across the Atlantic. This campaign was overt about its privileging of issues related to the alienation of people of colour in higher education or their sense of alienation in these institutional contexts. These recent campaigns are best understood as contemporary articulations of a longer history of protest against black people's exclusion from higher education in South Africa (Higham 2012), and growing feelings of discontent among black students and academics that, despite overcoming apartheid university curricula and institutional cultures, remain largely colonial and white-normative (Badat 2010). Thus, these campaigns produced several other innovative student actions in addition to the regular politics of spectacle (Habib 2016) that, among other things, took the form of confrontations between armed police and chanting students. At the bigger metropolitan city universities of Cape Town and Witwatersrand in Johannesburg, students occupied administrative buildings through sit-ins and occupation. At the University of Cape Town, the vice-chancellor's office building was renamed Azania House, and, at the University of Witwatersrand, the occupied building was named after anti-apartheid martyr Solomon Mahlangu. These occupations lasted for months at a time and saw students use them as their campus campaign centres, where they would invite regular speakers, hold workshops, and use them as a space into which to invite the university administration for meetings. At the University of Stellenbosch, students in the theology faculty took portraits of colonial and apartheid-era deans and turned them upside down or facing the wall in acts of defiance. Elsewhere, colonial and apartheid-era art and portraits were removed, damaged, and/or burned. At several campuses, students erected makeshift shanty homes to symbolically highlight the socio-economic realities of many students (Evans 2016), while, elsewhere, women students staged nude protests against police brutality. In her account of violence in the student campaign, Hlengiwe Ndlovu (2017) explained that " ... the moment that we stepped into the protest, because as much we were displaying the intolerance of violence, at the same time, it was a form of resistance to say the very same woman's body is capable of ceasing fire and no one from national or local government could stop it." The women achieved their objective for the intervention; police officers withdrew and ceased fire against the shield of naked black bodies.

On provincial university campuses, students incorporated indigenous religious rituals into their protest action through the burning of mphepho (an indigenous herb burnt as incense) as a protective measure against police violence and the incorporating of their ancestors into their campaigns for decolonizing the university. In this context, religion offered an accessible and tangible register for marking out the sacred, legitimating the student protest action and linking the current struggle to a primordial ancestral struggle for recognition. The invocation of the ancestor through the burning of mphehpo as an indigenous ritual not only centred and incorporated the ancestral into the student campaigns, it also produced local articulations of what constitutes decolonial protest action. What I mean by this is that while occupations, sit-ins, and protest marches echo transnational civil society practices, the invocation of the ancestral disrupts regular ideas about resistance. The incorporation of the ancestral is more than merely instrumental and symbolic, and, through linking their current student campaign to a longer sacred struggle for recognition, these students activate the primordial as a register for legitimacy and action. In doing this, students used religious ritual as a mechanism to mediate and introduce new, indigenous, and decolonial registers through which they could produce protest action.

These efforts to incorporate the indigenous or to more meaningfully reflect on the lived reality of the African students that attend university must be viewed in relation to projects concerned with 
decolonizing the university. The decolonial project cannot be simply about changing the curriculum; it must also be about changing the institutional and social cultures of universities. Black students and scholars, as well as women and indigenous persons, have often felt out of place in these institutional contexts and have embodied experiences of being treated as space-invaders or intruders (Ahmed 2012; Mirza 2015), which, in turn, produce various kinds of imposter syndrome. The push-back against this long history of exclusion has taken various forms of campaigning for black academic associations, scholarship schemes for black students to enter postgraduate research, and so forth. While there has been formidable scholarship in the field of decoloniality, exemplified by the work of Nelson Maldonado-Torres, Ramon Grosfuguel, Linda Tuhiwai-Smith, Sabelo Ndlovu-Gatsheni, and Maria Lugones, it is only in recent years that students and faculty in South Africa had begun to grapple with the implications of decoloniality in campaigns such as \#Rhodesmustfall and \#Feesmustfall. In a presentation titled "Decolonising knowledge and the Question of the Archive," Achille Mbembe (2015, p. 6) notes that "when we say access, we are also talking about the creation of those conditions that will allow the black staff and student to say [about] the university: This is my home. I am not an outsider here. I do not have to beg or to apologize to be here. I belong here."

In the South African student campaigns of 2015 and 2016, one of the most contested issues was that of violence-violence by security personnel and public order police in their efforts to contain student action, as well as violent acts by students as they reportedly damaged university property. In many places, public campaigns have been met with violence, and it has become a taken-for-granted aspect of public protest culture (Duncan 2016). In South Africa, where at least 30 service-delivery protests occur daily, the violence that accompanies such protests has become such an everyday occurrence that the media barely reports on it any longer. Thus, as students on university campuses outside the metropolitan areas produced local chapters of the \#Rhodesmustfall and \#Feesmustfall campaign, we noticed that it was evident that a different kind of violence was reserved for students on largely black university campuses (Engh and Settler 2016). As a university lecturer of religion and race, I, together with colleagues from various disciplines, was outraged at the violence directed at our students; we, like our peers on other campuses, chose to support our students' rights to plan, structure, and state their protests. Our efforts to support the students on our campus resulted in a newspaper article in a national paper in late September 2016 with the title "Profs of protest: University staff accused of 'fuelling' plans to destabilise campuses." Despite this and other criticisms of us as academics, we defended our support of the students and, in an open letter published in October 2016, stated that:

"Although we find the article untrue and full of spurious claims, we embrace the designation 'Professors of Protest,' despite the slanderous intent. If it means that we offer a space for free and critical dialogue about academic and financial exclusion; if it means decolonising the curriculum; if it means fighting, teaching and writing for social justice; if it means we put our bodies between students and security services to defend the right of our students to register their dissatisfaction, alienation and marginalisation; and, finally, if it means we defend the public university as a space for critical dialogue and exchange, then we are, proudly, Professors of Protest." (Settler et al. 2016)

As researchers and lecturers, we saw our role as defending the university as a space for critical dialogue and providing spaces for students to explore and examine their lived reality. As the repression of dissent persisted, and almost all avenues for deliberation among students had been 'banned' from campus, myself, together with three colleagues from visual art, drama, and anthropology, decided to offer a form of public pedagogy through art. It emerged as an organic effort to help students reflect on their reality, and so we began a process of reflection teaching, learning, speaking, and curating violence during the 2016 \#FMF campaign at UKZN's Pietermaritzburg campus. Through this collaboration, we curated three public art events that not only addressed issues of violence on campus but also invited critical reflection and deliberation among students. Since these installations and performances did not register as protest action with security services, they provided a safe space for students to meet, reflect, and exchange ideas. 


\section{Race and Violence in South African Student Politics}

It goes without saying that reflections on, theories about, and discourses on violence emerge most pertinently in contexts of discontent, struggle, and repression. The encounters with violence have shaped much of the \#FMF students' struggle-which has been variously defined as violence of exclusion and violence of dismissal enacted on black African persons.

As students, activists, and academics have sought to articulate the moral, ideological, and theoretical foundations of this student campaign, they have invoked the writing of theorists such as Frantz Fanon and Steve Biko because they believed these writings best speak to their lived condition. This history of entanglements of Fanon and Biko in the South African struggle is best captured in Nigel Gibson's Fanon Practices in South Africa, in which he maps the various ways in which Fanon has been incorporated and animated in various South African struggles after apartheid. Gibson's attempt to engage "Fanon's untidy dialectic with new realities" (Gibson 2011, p. xvii) leads him to survey Fanon's influence over struggles for recognition from Steve Biko's black consciousness in 1970's South Africa to the struggle for basic service by shack-dwellers associations in post-apartheid South Africa. This survey includes Biko's 1970 essay Black Souls in White Skins, echoing Fanon's Black Skin, White Masks, culminates with an examination of the contemporary shack-dwellers association, Abahlali baseMjondolo, as an embodiment of Fanon's pitfalls of national culture in its siding with the poor and distancing itself from the postcolonial state (Gibson 2011). Reflecting on the same social movements, Kerry Chance (2018) eloquently argues in her Living politics in South Africa's Urban Shacklands that fire, water, land, and pollution frames the material realities of the urban poor in South Africa, and that fire has been deployed by the poor as a weapon of resistance against government practices. In their various protest actions against the lack of basic services, these movements appeared to rely on a Fanonian register of violence to legitimise their particular forms of protest action, including road blockages, performative demonstrations with traditional weapons, and arson. In translating the Fanonian practices of the urban poor to the university context, students sought to read Fanon's views of violence; on three occasions in 2016, I was invited to facilitate seminars on Fanon, Race, and Violence. In these contexts, students cited Fanon's assertion that:

[d]ecolonization is the meeting of two forces, opposed to each other by their very nature ... [t]heir first encounter was marked by violence and their existence together (Fanon 1968, p. 36)

Wretched of the Earth is run through with references to violence enacted on the bodies and communities of colonised people, with Fanon asserting that while violence in this context is the product of colonialism, and a collective catharsis is necessary for the colonised subject to violently rid themselves of colonial rule (Fanon 1968, p. 42). While many student activists found resonance in Fanon's notion that "violence ... frees the native from his inferiority complex and from his despair and inaction; it makes him fearless and restores his self-respect" (Fanon 1968, p. 94), many were keen to draw attention to effects of sustained police and social violence on their sense of confidence and feeling part of the university community. During these periods, students often articulated their campaigns as struggle and combat. For example, at one university, a student reported: "You know the police, they simply come and start firing rubber bullets, teargases, and water cannons to disperse students. This is what makes things worse" (Protest student 15, Tswane University, November 2016); 12 months previously, the Student Council, frustrated by failed talks with the university administration in a letter to the executive of the same university, wrote "We are ready to die for a black child to be granted his or her right to education" (Vilakazi 2017, p. 54).

These sentiments of combat and the courting of violence were shared by those involved in the student campaigns across the country. Students sought to access various ideological and theoretical registers for explaining and analysing their experiences of violence. This included the inconsistent and ambivalent courting of theories such as Mbembe's necropolitics because it points to the suggestion that "technologies of destruction have become more tactile, more anatomical and sensorial, in a context 
in which the choice is between life and death" (Mbembe 2003, p. 34), as well as Spivak's epistemic violence, insofar as it drew attention to institutional practices and structures of knowledge that silences the experiences of the (formerly) colonised. While most students in these campaigns had little working knowledge of Spivak or Bourdieu's symbolic violence, they believed that institutions of higher learning and accompanying knowledge regimes were produced to control and exclude the Other. They further believed that destabilizing or confronting such endemic violence was only possible through riots and mutinies (Spivak 1999). The recent student campaigns in South Africa such as \#RhodesMustFall and \#FMF represent such moments of contestation, critique, and theorizing about violence-partly because they are also a convergence of material violence, state violence, systemic violence, institutional violence, and epistemic violence.

In the aftermath, a range of texts have been produced on the social, political, and economic impact of the \#Rhodesmustfall and \#Feesmustfall campaigns. This growing field of inquiry proliferated across southern Africa, producing texts such as Fees Must Fall: Student Revolt, Decolonisation and Governance in South Africa edited by Susan Booysen (2016), Rebels and Rage by Adam Habib (2019), As by Fire: The End of the South African University by Jonathan Jansen (2017), and \#FeesMustFall and Youth Mobilisation in South Africa: Reform or Revolution? by Musawenkosi W Ndlovu (2017). Overall, these texts are the result of work by political scientists and educationists who variously try to account for either the forces that resulted in these campaigns or to frame and propose possible futures for the African University. One volume that resonates with our curatorial efforts is the student publication Rioting $\mathcal{E}$ Writing: Diaries of the Wits Fallists (2017), wherein students who were active in the movement produced personal narratives incorporating body, gender, protest tactics and solidarity with groups beyond the university. This latter volume attempts to both give an account from the perspective of the students as well as serve as a popular pedagogical effort whereby students were afforded the chance to think through the issues they wanted to write about and publish, as well as the broader purpose(s) of discussing and disseminating their ideas. On our campus, we constructed three curatorial moments to similarly help students and staff think through the meaning of violence in the context of the university.

Framing these student campaigns as violent, seditious, and disruptive was not simply a product of media imaginaries, although it played its part. What is beyond question is the fact that violence happened. It was enacted upon our students. Students committed arson through the burning buildings, books, and cars. Students were arrested, shot, and brutalized, and staff was threatened. While much of these acts of violence, arson, and vandalism are contested, that it happened is not disputed (Grassow and Le Bruyns 2017). Until late 2016, many South African university campuses remained occupied by police and security services, with many universities having established a police command centre on campus, supported by a court interdict. As we witnessed a change of rhetoric from speaking of students as clients to speaking of students as criminals, I wrote a piece with a colleague commenting on the violence perpetrated on predominantly black university campuses. We concluded that:

"Witnessing the enthusiasm and "glee" with which police and security staff enforce the interdict, it is hard not to agree with students' assertions that this is a level of intimidation and brutality by police and dismissal by university management is reserved for black students at provincial campuses."

The escalation of violent repression by the state, university managers, and security services was met, nationally, with an escalation of resistance (Booysen 2016). As students' arrests increased and raids on student residences became commonplace, many sought refuge in local churches and in other places, religious leaders and staff presented themselves as protective shields as they placed their bodies between protesting students and police (Munusamy 2016). For much of the period of the campaign, especially during late 2015 and early 2016, our social media was saturated with images of violence as we adjusted to increased securitization or militarization of campuses. Students, staff, and the general public were glued to their smartphones and laptops, producing, reporting and consuming "protest porn." 
A widely debated aspect of violence in the student campaigns was the issue of arson, with most newspapers reporting largely on what students burnt and very little about police brutality. Kerry Chance, in her book, Living Politics in South Africa's Urban Shacklands, reminds us that arson has been commonplace in South Africa struggle for resistance and social self-determination. This opens the possibility of imagining violence or arson in protest cultures as more than just deviant or undesirable. Chance (2018) argues that in the face of armed authority, fire is an accessible form of resistance-it is ignition in the hands of the poor, where "between life and death, fire draws its ultimate line of difference."

Attempts by students and staff to speak and think through the violence, arson, and intimidation were largely met with silence, anxiety, and a reluctance to speak publicly, and there appeared to be a lack of a suitable language to articulate the complex engagements with violence that we as a community—staff and students-experienced. On most campuses, the various court-mandated interdicts prevented students from gathering in public spaces across the campuses in groups of more than five. Students were prevented by management from meeting and speaking about what was happening. Moreover, we/they also lacked the language to speak or make manifest our collective/individual trauma-whether in a desire to speak to Mbembe's notion of the necropolitical threats to life or to Spivak's notion of epistemological violence of exclusion and representations of students as criminal. We were numbed and muted. We could not feel, and we could not speak.

\subsection{Three Curatorial Moments}

During late 2016, at the height of the repression by the state, courts, and university administrators, conditions on my local university campus, as was true also for most university campuses across the country, meant that university programmes continued under highly securitised conditions. Students were barred from meeting in groups outside lecture and seminar venues, and all main teaching venues were guarded by security staff who controlled access. Those who contravened these conditions and engaged in group protests, occupations, or sit-ins were arrested and imprisoned. For two weeks during the third academic term of 2016, a group of concerned faculty invited students—any students-to attend seminars that we convened at a large teaching theatre. We used these seminars as opportunities for students to meet and talk about their concerns in a safe space. These learning events included poster design and printing, writing blog posts, contextual bible studies, and site-specific theatre performances. Soon our pedagogical efforts were curtailed, and concerned staff were denied the use of this teaching theatre, thus leaving no space for students to meet or discuss their needs, concerns, or collective strategies related to the two national student campaigns.

At our campus, the academic programme was either suspended as a strategic effort to quell disruptive protests (Grassow and Le Bruyns 2017), or the academic programme we claimed to continue as normal, with extensive surveillance by police and security staff controlling access to campus and key buildings. In the face of this severe repression, students moved about the university anxious, angry and traumatised. In an effort to craft as collaboration, myself and three colleagues from visual art, drama, and anthropology, as well as some student leaders, began a process that saw us curating three events that gave critical accounts of the violence that the students experienced, provided commentary on the adverse impact of the violence on the university community, and provided a space for engagement and deliberation in the midst of a violently repressive context. The decisions related to the type of curated events was the result of organic but careful planning, insofar as the three events were not planned together but emerged in relation to each other. As academic staff, our first effort was to create a space for public reflection about the 'new normal,' and while the subsequent performance and installation were intended as a critical commentary, they also served as spaces for student to voluntarily participate in the curated event through registering their experiences or thoughts on the violence that characterized the student campaigns. While we enjoyed a shared idea of curating a selecting, organizing, and representing ideas, images, and events, in this context we approached curating as a contextual practice concerned with framing the political economy of art (Greenberg et al. 1996, 2ff; 
Lacy 1995) or what Chantal Mouffe (2013) regards as the radical potential of the artistic for shaping hegemonic struggles for public space. In this regard these curatorial events had the dual functions of being a commentary and critique on the violence inflicted on students, as well as a catalyst for a decolonial public pedagogy or border pedagogy. They contributed to the ongoing deliberation about the role and significance violence in the student campaigns.

\subsection{Prisoners' Memorial}

Between 22 September and 10 October 2016, 21 students from the Pietermaritzburg campus of UKZN were arrested and imprisoned, charged with public disorder and contravening the university's interdicted against meeting in group in public. The university announced that the trouble-makers had been removed and that the academic programme would return to or continue as normal (Grassow and Le Bruyns 2017). Nothing about the state of security and imprisonment of those students was normal. Despite the fact that staff and students had been prevented from meeting and speaking the arrests as a community, I wanted to make visible the trauma and absence of students in prison. With colleagues, I built a memorial—it was constructed at home and installed on the main campus, the site of the then-banned meetings, exclusions, and arrests (Figure 1). The memorial mimicked a cemetery and took the form of 21 flattened black refuse bags secured to the ground in neat rows on the grass lawn in front of the main campus library. On each flattened plastic bag, there was a sheet of paper detailing the name of an arrested student, where they were imprisoned, and the number of days they had been incarcerated.
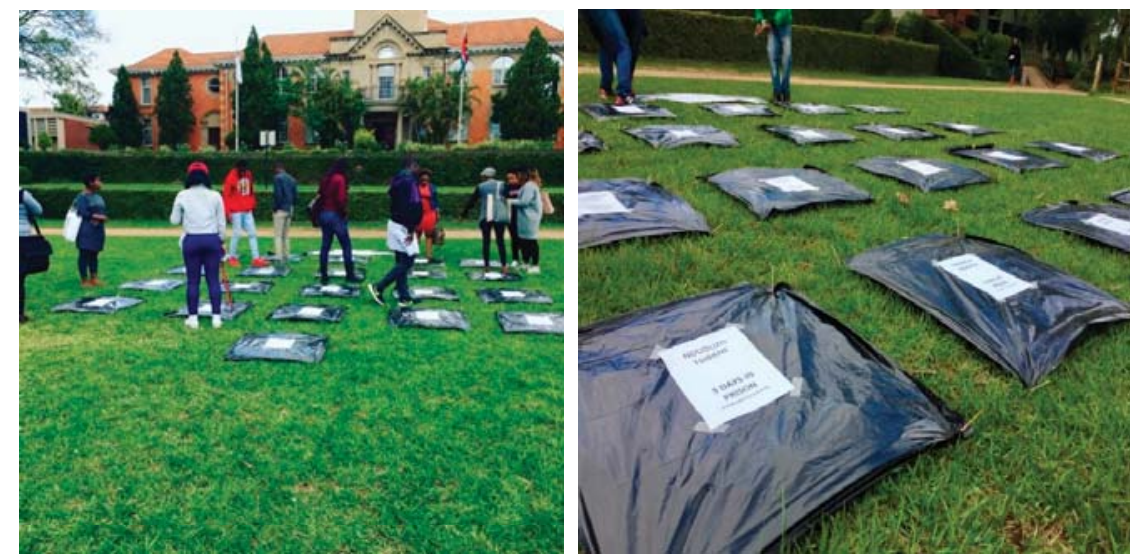

Figure 1. Prisoners' Memorial.

This memorial had an immediate impact, and it drew students' curiosity. As an artistic installation, it was not regulated under the court interdict. Students from across the campus came and read or stood in silence to remember their colleagues. Several students sat down and cried, while others expressed shock that fellow students had then been imprisoned for more than 10 days at a regional high-security prison. As faculty, we did not intervene nor seek to direct student reflections or comments. Students lingered, occupied the space, and left; others would return with friends. The popular sacrality of the memorial space kept security staff at a distance. Though it was a sombre space, detailing student biographies and number of days incarcerated, it was also a space for critical reflection and deliberation between students and faculty invested in the outcome of the campaign. For those students who viewed the \#FMF campaign from a careful distance, worried about the violence of the police and alienated by the violence of some students, this memorial brought into focus political and material dimension of student's imprisonment and the institutionalised violence. We observed students and faculty register outrage at the fact that their peers were arrested and imprisoned for speaking up about the conditions 
of higher education. A few noted that the memorial itself was subversive insofar as it provided a space for students to gather and reflect on issues of exclusion and alienation in higher education.

Curating this memorial was a deliberate effort to speak to the social death that comes from the imprisonment of dissidents and protestors. Where ordinarily war or conflict sites and monuments memorialise entanglements with violence through producing public sites as "vehicles of memory," which tend to create martyrs and victims (Jelin 2007; Duncan 2009), this curatorial effort drew attention to the threat of death. Further, it not simply memorialised the absent but also humanised those imprisoned, creating lines of affinity and affect between those absent and those standing in the prisoners' memorial. Through creating a bounded space, with imagined sacrality, we facilitated a space for learning and reflection where students brought their respective experiences of violence on campus into conversation with the real and lived realities of both the prisoners, as well as other students amidst the memorial—thus creating a participatory learning space.

\subsection{Poetics of Protest}

Several weeks after curating the prisoner's memorial, we hosted Koleka Putuma, a nationally renowned poet. Together with a group of student leaders, we agreed to use one of our regular monthly mentoring meetings for black staff, students, artists, and activists as a space for students to meet. We conjured up Poetics of Protest - an event where Koleka Putuma performed her poetry and invited students to read their own writing about the conditions on campus during the preceding months. The event (Figure 2) ended with her doing a final series of poems and group exercise on black worlds and interiors. This was conceived as a space for students to speak, and attempt to find words and to be offered space to speak into. The event incorporated poets and students from across the campus and a local Zulu (vernacular) poetry collective.
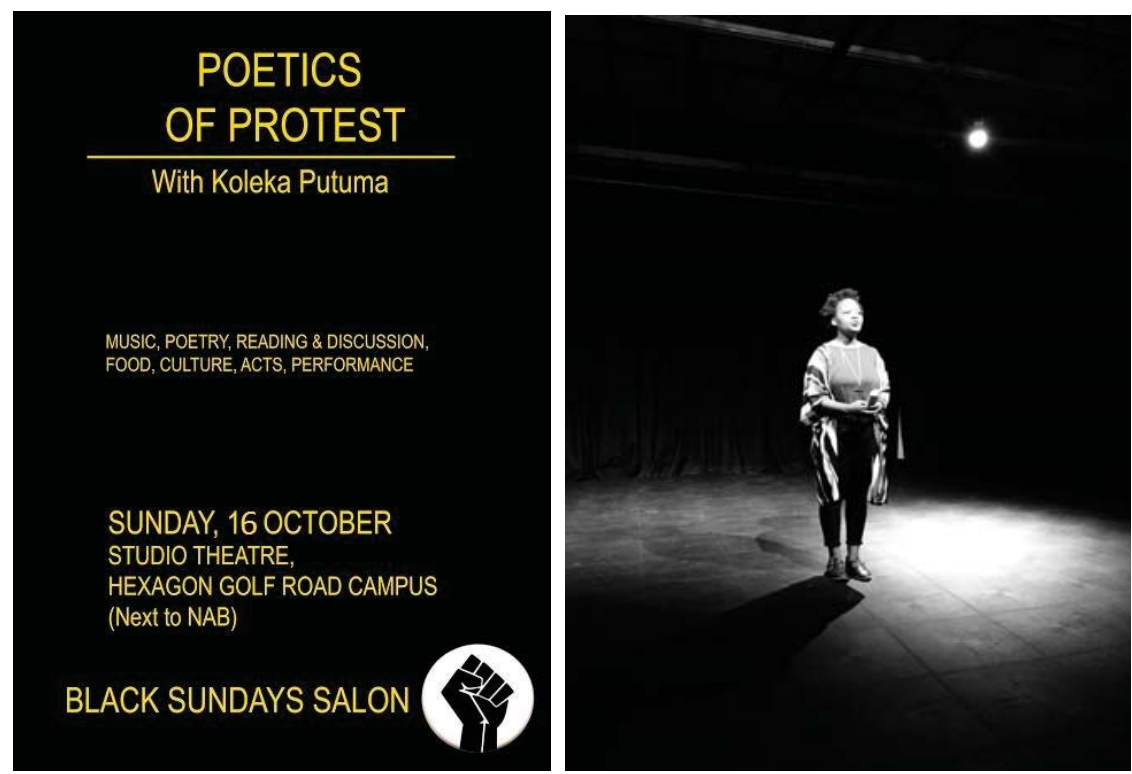

Figure 2. Poetics of Protest.

In a context where the politics of spectacle and performance had currency (Habib 2016), the invitation to participate in a poetry session was met with skepticism among most students. Nevertheless, Poetics of Protest gained momentum as we sought to facilitate alternative modes of protest, speaking, and thinking-and it was well attended because it provided a space for students to meet in large 
numbers and speak publicly about decolonising the university and the repressive measure of the state and university leadership. It forced academic staff and students to engage in forms of resistance and subversion that did not involve, nor bait, direct violence from the police and security services. Putuma's poetry, now published in the volume Collective Amnesia, resonated with students' social reality drawing strong linkages between the symbolic and epistemic violence of being black on South African university campus in 2015 and the generally dismal condition of black people's lives 25 years after the advent of democracy. Putuma's poem "Water" resonated with many:

- Yet every time our skin goes under,

- it's as if the reeds remember that they were once chains,

- $\quad$ and the water, restless, wishes it could spew all the slaves and ships onto shore,

- whole as they boarded, sailed and sunk.

- Their tears are what have turned the ocean salty,

- $\quad$ this is why our irises burn every time we go under. (Putuma 2017, pp. 96-100)

This, an excerpt, from the poem, was greeted with raucous support and laughter captured the mood of alienation and frustration among the students, and when another of Putuma's poems offered a critique of the violence against women in the \#Feesmustfall and \#rhodesmustfall movements with her poem "On Black Solidarity," it was greeted with a sombre discomfort. The poem opens as follows:

- $\quad$ Black solidarity does not include making my spine a doormat

- so that you can stand or have a backbone

- Black solidarity as the expense of a black womxn's anything, is a farce, a rip-off.

- The kind of violence they shred into laughter at the police station

- $\quad$ And replay in front of you just to make sure you got the joke (Putuma 2017, pp. 80-82)

After what seemed like weeks of running battles, police raids, and prison visits, students were battle-fatigued, and this poetry session afforded students a sanctuary from violence and surveillance, as well as a space for reflection. While, on the one hand, the poetry session allowed space for recognition that opened-up some wounds of pain and anger, the cathartic poetics of protest opened another avenue for deliberation about the meaning and experiences of violence. Where the Poetics of Protest was a departure from the Prisoner's Memorial was in the fact that it not only drew attention to violence enacted on black students by the police and security service but also to the various ways that through design and execution of struggle, the student movement at times mimicked the forms of violence that they sought to condemn (Booysen 2016). We would later learn that following the event, students gathered in smaller groups in the residences and homes to continue the discussion about the relationship between decolonizing higher education and the struggle with the broader social struggle for human dignity in the communities they come from. "On Black Solidarity" opened up the possibility of a critique related to violence enacted by activists, and this became evident from the efforts by queer and gender activists not just critiquing institutional patriarchy but also patriarchal forms of struggle, and its entanglement with particular forms of violence (Ndlovu 2017).

\subsection{Public Sculpture}

The third curatorial moment, a public sculpture, forced us to think more deeply about the pedagogic intent of our efforts as resistance art, insofar as we hoped that it would present a response to the conditions of violence, a piece that would provoke students to reflect on and speak about the violence. We produced a public sculpture that was a commentary on the collective experience of violence and arson, to mourn losses - of innocence and things, to remember trauma, fire, and fear-and the abnormality of our existence made 'legal' by the interdict. Four staff members developed the sculpture (Figure 3), which was made up of steel-frames of desks, barbed wire, with slogan printed t-shirts, a mirror, and burned textbooks on a bed of salt. The sculpture of charred texted books, clothes and twisted metal was meant to capture the twisted and entangled relationship of students to 
the university, and that it was covered in barbed-wire represented the restriction and repression of student protests. In a highly symbolic move, we placed a mirror in the centre of the piece as a way to incorporate the student-viewers into the sculpture. It provided a space of recognition, exchange, and reflection. No commentary accompanied the sculpture and we left it up to each student to leave their mark in the salt, or on the chalkboard. Many sat and discussed the meaning of the sculpture with their friends. The paradox of this curating of violence and fire, on a campus under repression was not lost on the students. Many of them were anxious that we or they would get into trouble, but we explained that we simply presented a commentary on what we observed about social and institutional relations on campuses across the country.
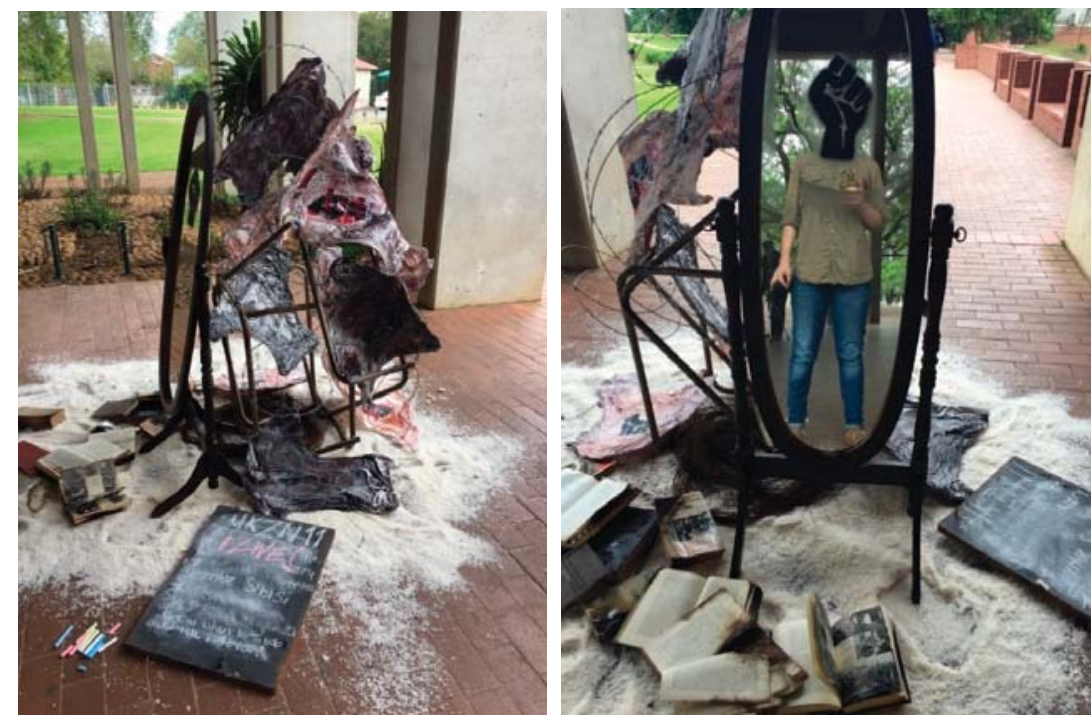

Figure 3. Public Sculpture.

Originally, we intended to burn the sculpture as a final act, but this was not permitted by the administration. As a commentary on violence and arson, it was firstly intended to disrupt ideas about where learning might take place through erecting the sculpture as a public classroom. Secondly, it sought to incorporate the context and students' experiences of violence into the learning space. At an epistemological level, it was meant to raise questions about what knowledge is valued and what life discourses are centred in the exchange between lecturers and students. The sculpture served simultaneously as a commentary on violence and a critique of violence, thus making possible nuanced and inclusive deliberation about violence that does not simply rely on binary articulation violence as diminishing (Arendt 1969) or liberative (Fanon 1968). It is my view that the public erection of the sculpture created sentiments of sacrality through placing students lived experience at the centre of a public pedagogical act that allowed learning to be continuous beyond what we as creators imagined.

\subsection{Border Pedagogy as Public Pedagogy}

In their examination of how to cultivate Walter Mignolo's border thinking among Mexican students, Cervantes-Soon and Carrillo (2016) argue that border pedagogy privileges the epistemologies and ways of being in the world of those who find themselves in colonial, social, and institutional borderlands. As they explore their students sense of alienation by and within mainstream educational institutions, Cervantes-Soon and Carrillo argue that border thinking "instead constitutes a potentially radical way of re-imagining knowledge and educational practices for oppositional social transformation" 
(Cervantes-Soon and Carrillo 2016, p. 282). It is premised on the idea that students are possessors of knowledge, and that pedagogy's aim is to help student locate themselves within their own social context, with the view to activate new knowledge registers born from their lived experiences. In the context of the South African student campaigns of 2015 and 2016, I am not claiming that we decolonized the curriculum, but, in the context of violence and repression, we were by necessity required to work with an anti-imperialist model of teaching and learning. As such, these three curatorial moments not only disrupted the relationship between academic facilitator and students but opened new registers for thinking, and speaking about violence in the context of the university.

With regard to the experiences of fire, arson, and violence, black students have deep and intimate archives of knowledge that predate their coming to university. We learned that students possessed reservoirs of knowledge with respect to the power of fire and violence as a way to draw a line in the sand. For some, burning barricades in the street was a scream against poverty and alienation, while, for others, direct conflict was a mere extension of a longer history of intimate and institutional violence. Further, the manner in which many young black men and women move in social space betrays their acute awareness of being subject to particular regimes of surveillance-reinforcing their sense of alienation, of being out of place.

This reality resonates with Cervantes-Soon and Carrillo's argument that "By recognising these subaltern knowledges of border thinking, border pedagogy repositions people on the margins as creators, thinkers, and knowers. This constitutes the very condition of possibility as youth are given the opportunity to reclaim their agency and challenge dominant and Eurocentric intellectual thought in creative ways" (Cervantes-Soon and Carrillo 2016, p. 286). Similarly, Geoffrey Harpham, in his (Harpham 2005) New Literary History, reminds us that no subject in the humanities can satisfactorily address a social phenomenon, such as violence, as they are all concerned concern fundamental issues relating to humanity; we, in the humanities, must see as the natural sponsor of the debates and controversies that frame such issues. Together with my colleagues, I found that it was precisely through drawing on different disciplinary traditions that we were able to produce a range of publicly curated events that made possible varied ways of representing violence and enabled us to facilitate critical, gendered, and indigenous deliberations about violence.

As we attempted to nurture students subaltern knowledges, we drew on registers in art, drama, religion, politics, and education to facilitate the three curatorial moments also as a way to explore the relationship between knowledge and power in the context of violence against black students. Lucy Lippard (1997) suggests that the landscape and vernacular of the art object are best understood in terms of the space, or context within which we live. Walter Benjamin (2005), on the other hand, suggests that art renders accessible what was previously distant or unreachable. Like art, religion emerged as a resource in sanctioning the student's campaigns and legitimating violence, not an uncommon practice in South Africa (Chidester 1992). In particular, the sentiments of the ancestral invoked through the prisoner's memorial and the poetics of praise singing (imbongi) located the ancestral and the religious at the heart of the curatorial and pedagogic effort. Thus, religion emerged as not just legitimating violence but also as a register through which to understand, interpret, and make sense of violence in the context of the student campaigns for decolonizing South African universities. As such, the university became a landscape wherein which black students' told their stories of struggle and biographies as space invaders. What these curatorial efforts made possible were reflections on violence as ways to mediate subjectivities, to regulate access, and to register protest.

However, while these experiences of racialized violence as archives of knowledge are excluded from the regular knowledge economy of the university, the violence of protests and the desire to obliterate through fire must be examined as a way to reflect on what it represents. To dismiss violence and arson by students or protestors as socially deviant and undesirable closes the possibility to speak, teach, and theorise about important aspects of black students' experiences in ways that take it as serious and valued. This foreclosure itself is a is a kind of epistemic violence itself. The decolonization of higher education requires that we centre those black experiences and experiences of women that 
move beyond the victim-villain trope-those experiences and knowledge registers that disrupt our comfort. Through curating violence, we hoped to place other ways of knowing, knowledge registers pertaining to violence at the centre of our pedagogical deliberations, as a way to privilege our students' experiences of violence, racism, and the ancestral over the supposedly universal white western ways of knowing and being, to produce a border pedagogy.

\section{Conclusions: Curating Violence}

The particular pedagogy pursued in the development of the three curatorial moments elaborated above was made possible by converging registers of meaning-making from religion, social science, and the arts. In an effort to help students reflect on their experience of violence and their efforts to decolonise the university-through deracializing and queering the curricula and making a democratic classroom-these curatorial moments were facilitated to interrogate the relations between power, dominance, and knowledge. Especially in a context where students were denied opportunities for meeting in large groups to reflect on and deliberate around their experiences of violent repression, these curatorial moments provided not just a space for meeting but also sought to help student think through their experience of violence, to reflect on the impact of violence, and to honestly discuss their ambitions with respect to deploying violence as an anti-colonial measure.

As academics and students, we were conscious that dealing with the topic of violence and arson on our campuses had become an unspeakably hot topic, so to speak, because it had emerged as a container for a wide range of anxieties, anger, and ambitions. On the one hand, it represented the animation of shackland protest strategies such as burning barricades on university campuses where it was alien, and, on the other hand, it scripted new discourses of protest cultures while closing down broad-based discussion of the meaning of violence. Through offering three differently curated events related to the issue of violence, the hope was to facilitate a public border pedagogy that would allow students to reflect on their experience and practices with the view to socially transform the university. This was made possible particularly because, on the one hand, art as social commentary and representation emerged as an acceptable medium through which to critique the repressive conditions, while religion, on the other hand, provided an accessible and indigenous register for making meaning. In the South African context, the invocation of the ancestral through the burning of incense or through funerary rites or depictions such as the prisoner's memorial entices popular piety. While the memorial invokes the necropolitical threat of death, it also humanised the absent and imprisoned students. In this sense, it was more than a memorial. Likewise, the praise-singing of fallen heroes and long lost slave ancestors echoed in the Poetics of Protest connected the contemporary student struggle within a longer primordial struggle for recognition. The recognition of these accessible, local religious rituals provided students with a register within which to make sense of an articulate their understanding of violence and about the transgressive and productive power of fire.

Further, I would argue that the public border pedagogy was made possible through the process of curating as a continuous deliberating process. Unlike the memorialisation of violence and its making of martyrs, curating violence emerged as an ongoing participatory pedagogical process that allowed staff and students to think through the intersection of knowledge and power with violence and resistance. The curated events invited more than just a gaze, insofar as all three events invited participation or presence. In order to read the prisoner biographies on the prisoner's memorial, student had to enter a seemingly funerary space, erected on the site of student clashes with police. Similarly, the Poetics of Protest and the Public Sculpture disrupted the seemingly normal order of campus through inviting students to enter into proximity with a curatorial event that overtly referenced violence against students.

Finally, all three curatorial moments engaged registers of the sacred and the artistic to make possible deliberations about violence otherwise not possible. This allowed students to reflect on and speak about violence and to develop language, theories, and competencies related to their experience of violence that does not only rely on the thoughts and words of Fanon, Bourdieu, Spivak, or Mbembe 
but one that also draws on indigenous registers of sacrality. In this regard, the three curated events opened border pedagogical discourses about violence as not just material or instrumental but also about violence as sacred and as mediation over who and how to frame the decolonial project.

Funding: This research received no external funding.

Acknowledgments: The author extends recognition and appreciation to colleagues from University of KwaZulu-Natal for their collaboration in developing the final art installation in this series of three curatorial events. They are Tamantha Hammerschlag (Drama), Wayne Reddiar (Visual Art) and Mari Haugaa Engh (Anthropology).

Conflicts of Interest: This research received no external funding.

\section{References}

Ahmed, Sara. 2012. On Being Included: Racism and Diversity in Institutional Life. Durham: Duke University Press. Arendt, Hannah. 1969. Reflections of Violence. Journal of International Affairs 23: 1-35.

Badat, Saleem. 2010. The Challenges of Transformation in the Higher Education and Training Institutions in South Africa. Johannesburg: Development Bank of South Africa.

Booysen, Susan, ed. 2016. Fees Must Fall: Student Revolt, Decolonisation and Governance in South Africa. Johannesburg: Wits University Press.

Benjamin, Andrew. 2005. Walter Benjamin and Art. London: Continuum.

Bourdieu, Pierre. 1990. The Logic of Practice. Translated by Richard Nice. Stanford: Stanford University Press. First published 1980.

Bourdieu, Pierre. 2001. Masculine Domination. Cambridge: Polity Press.

Chance, Kerry. 2018. Living Politics in South Africa's Urban Shacklands. Chicago: Chicago University Press.

Cervantes-Soon, Claudia, and Juan. F. Carrillo. 2016. Toward a Pedagogy of Border Thinking: Building on Latin@ Students' Subaltern Knowledge. The High School Journal 99: 282-301. [CrossRef]

Chidester, David. 1992. Religions of South Africa. London: Routledge.

Duncan, Christopher. 2009. Monuments and martyrdom Memorializing the dead in post-conflict North Maluku. Bijdragen tot de Taal-, Land-en Volkenkunde 165: 429-58. [CrossRef]

Duncan, Jane. 2016. Protest Nation: The Right to Protest in South Africa. Pietermaritzburg: University of KwaZulu-Natal Press.

Engh, Mari, and Federico Settler. 2016. At campuses like UKZN PMB, violence is used to force students into submission. The Daily Vox, September 6. Available online: http://www.thedailyvox.co.za/mari-engh-federicosettler-ukzn-pmb/ (accessed on 3 February 2017).

Evans, Jenni. 2016. \#Shacksville: UCT Protesters Braai on Jammie Steps (15 February 2016). Available online: https://www.news24.com/SouthAfrica/News/uct-protesters-set-up-shack-on-varsity-steps-0160215 (accessed on 6 March 2019).

Fanon, Frantz. 1967. Black Skin White Masks. Translated by Charles Lam Markmann. New York: Grove Press.

Fanon, Frantz. 1968. Wretched of the Earth. Translated by Constance Farrington. New York: Grove Press.

Gibson, Nigel. 2011. Fanon Practices in South Africa. Scottsville: UKZN Press.

Grassow, Lisa, and Clint Le Bruyns. 2017. Embodying human rights in \#FeesMustFall? Contributions from an indecent theology. HTS Teologiese Studies/Theological Studies 73: a4799. [CrossRef]

Greenberg, Reesa, Bruce Ferguson, and Sandy Nairne, eds. 1996. Thinking about Exhibitions. London and New York: Routledge.

Habib, Adam. 2019. Rebels and Rage: Reflecting on \#FeesMustFall. Johannesburg: JonathanBall Publishers.

Habib, Adam. 2016. Op-Ed: The Politics of Spectacle-Reflections on the 2016 student protests. Daily Maverick, December 5. Available online: https://www.dailymaverick.co.za/article/2016-12-05-op-ed-the-politics-ofspectacle-reflections-on-the-2016-student-protests/ (accessed on 6 March 2019).

Harpham, Geoffrey. 2005. Beneath and Beyond the 'Crisis in Humanities'. New Literary History 36: 21-36. [CrossRef]

Higham, Rob. 2012. Place, race and exclusion: University student voices in post-apartheid South Africa. International Journal of Inclusive Education 16: 485-501. [CrossRef]

Jansen, Jonathan. 2017. As by Fire: The End of the South African University. Cape Town: Tafelberg. 
Jelin, Elizabeth. 2007. Public memorialization in perspective; Truth, justice and memory of past repression in the southern cone of South America. The International Journal of Transitional Justice 1: 138-56. [CrossRef]

Lacy, Suzanne, ed. 1995. Mapping the Terrain: New Genre Public Art. Seattle: Bay Press.

Lippard, Lucy. 1997. The Lure of the Local: Senses of Place in a Multicentered Society. New York: New Press.

Mbembe, Achille. 2015. Decolonising Knowledge and the Question of the Archive. Available online: http://wiser.wits.ac.za/system/files/Achille\%20Mbembe\%20-\%20Decolonizing\%20Knowledge\% 20and\%20the\%20Question\%20of\%20the\%20Archive.pdf (accessed on 16 March 2019).

Mbembe, Achille. 2003. Necropolitics. Public Culture 15: 11-40. [CrossRef]

Mirza, Heidi Safia. 2015. Decolonizing Higher Education: Black Feminism and the Intersectionality of Race and Gender. Journal of Feminist Scholarship 7-8: 1-12.

Mouffe, Chantal. 2013. Agonistics: Thinking the World Politically. London: Verso Books.

Munusamy, Ranjeni. 2016. Holy Shield: \#FeesMustFall priest tells of his day of terror. Daily Maverick, October 11. Available online: https:/www.dailymaverick.co.za/article/2016-10-11-holy-shield-feesmustfall-priest-tellsof-his-day-of-terror/ (accessed on 6 March 2019).

Ndlovu, Hlengiwe. 2017. Womxn's bodies reclaiming the picket line: The 'nude' protest during \#FeesMustFall. Agenda 31: 68-77. [CrossRef]

Ndelu, Sandy, Simamkele Dlakavu, and Barbara Boswell. 2017. Womxn's and nonbinary activists' contribution to the RhodesMustFall and FeesMustFall student movements: 2015 and 2016. Agenda 31: 1-4. [CrossRef]

Putuma, Koleka. 2017. Collective Amnesia. Cape Town: uHlanga.

Settler, Federico, Pumelela Nqelenga, Clint Le Bruyns, Mari Haugaa Engh, Jane Quinn, Anne Harley, Ntokozo Madlala, Wilhelm Meyer, Fiona Jackson, Tamantha Hammerschlag, and et al. 2016. Letter: The 'Professors of Protest' at UKZN Respond to the M\&G's Story. October 7. Available online: https://mg.co.za/article/2016-10-07-00-letters-to-the-editor-october-7-to-13-2016 (accessed on 6 March 2019).

Spivak, Gayatri. 1999. A Critique of Postcolonial Reason: Toward a History of the Vanishing Present. Cambridge: Harvard University Press.

Vilakazi, Marcia. 2017. Tshwane University of Technology: Soshanguve Campus Protests Cannot Be Reduced to \#FeesMustFall. In \#Hashtag: An Analysis of the \#FeesMustFall Movement at South Africa. Edited by Malose Langa. Johannesburg: CSVR.

(C) 2019 by the author. Licensee MDPI, Basel, Switzerland. This article is an open access article distributed under the terms and conditions of the Creative Commons Attribution (CC BY) license (http://creativecommons.org/licenses/by/4.0/). 


\title{
Article \\ A Flexible Indeterminate Theory of Religion: Thinking through Chinese Religious Phenomena
}

\author{
Tak-ling Terry Woo이 \\ Department of Humanities, Faculty of Liberal Arts and Professional Studies, York University, Toronto, \\ ON M3J 1P3, Canada; twoo@yorku.ca
}

Received: 3 April 2019; Accepted: 1 July 2019; Published: 13 July 2019

\begin{abstract}
This essay explores a few of the reasons for the failure of Western theories to capture Chinese religious experiences. It will include Durkheim's insight that "The sacred ... is society in disguised form" and variants of secularization theories in contrast to Confucian ones, especially Xunzi's theory about ritual, read as representative of religion. This article will examine the impossibility of asserting a straightforward claim, without exception, that could capture the three thousand years of historical and contemporary diversity manifested by the three institutional religions (Confucianism, Daoism, and Buddhism), the continuous formation of popular religious movements, ever developing sectarian groups, and pan-Chinese quasi-religious practices like ancestor veneration, divination, healing practices and the like. The study will start by looking at variable categories used in the study of different religions, the similarities in assumptions among the three institutional religions such as the "good" and self-cultivation, and the central place of secularization theory in the contemporary study of Chinese religions. A theoretical orientation of both flexibility and indeterminacy is suggested based on indigenous ideas.
\end{abstract}

Keywords: Chinese religion; secularization; Xunzi; Durkheim; sociology of religion

\section{Introduction}

What is "Religion" and how is it situated in society? Is it the projection of a community as the sacred? ${ }^{1}$ Is it "false consciousness" — the "sigh of the oppressed, the heart of a heartless world" and "the opiate of the masses" $?^{2}$ Is it one crucial factor in shaping human character and endeavors? ${ }^{3}$ Is it superstition and destined for the dustbin of history? ${ }^{4}$ Is it a product like any other to be marketed and consumed? ${ }^{5}$ Does the "secular" state itself represent a religious community? ${ }^{6}$ Is religion a political

1 The emperor during historical dynasties was construed as the Son of Heaven and even the modern state itself, Liang Yongjia argues, "assumes a religious aura."

2 The upheaval during the 19th and early 20th centuries witnessed numerous examples of "false consciousness". Two examples with a twist away from reward in the next world toward active resistance using magic in this world will serve as illustrations here. The Taiping Rebellion (1850-1864), led by Hong Xiuquan who believed himself to be the younger brother of Jesus, claimed an estimated 20 million lives. And the Yihequan or the Righteous and Harmonious Fists, also known as the Boxer Rebellion in the West, was a peasant uprising that was encouraged by the empress dowager, Cixi, and supported by the Manchu government. The participants believed that their rituals made them impervious to bullets. They were slaughtered.

3 The voluminous literature on the effect of Confucian culture on the diligent and frugal individual and the subsequent successful development of East Asia is an example.

4 The New Culture Movement from the early 20th century is a clear example of this. It aimed to transform traditional Chinese culture by disassembling Confucianism, which was believed to perpetuate gender inequality, and Daoism and Buddhism, which were deemed superstitious and kept the populace mired in ignorance. Instead, the reformers introduced Western ideals of democracy and gender equality and encouraged scientific thinking.

5 All the Daoist and Buddhist paraphernalia including most visibly talismans and small shrines where various statues are placed; services like divination and installation of altars and shrines in stores to ward off unwelcomed supernatural forces are all examples of this.

6 Liang Yongjia argues that the Chinese state has never been secular. He writes that "For more than two millennia, the core ideological conviction shaping and buttressing imperial governance also direct correlatively the purpose and process to 
tool used by the state to manipulate a governed population? Or is it a tool for an oppressed population to foment a revolution? ${ }^{7}$ How do religions encounter each other? And, is religion an extrinsic way to enter a different culture through conversion and an expression and declaration of disaffection with the first? ${ }^{8}$ An investigation of the substance and function of religions in Chinese communities globally will result in affirmative answers to all these questions because they each apply to particular segments of the population. A universal theory about, or one that comfortably includes the substance and functions of religion in Chinese society, however, cannot at this point be determined.

That a universal sociology of religion cannot be determined is meant in two ways here: first, in the obvious sense that current Western theories fit badly to the Chinese case; and second, in the sense that a general theory of religion based on Chinese religious experiences must be able to account for other religions, be open to change as new ideas and practices develop, accommodate differences that arise from dissimilar historical conditions, be nimble enough to handle diverse native or "insider" perspectives, account for a continuum of preferences for homogeneity and diversity, and explain the privileging of uniformity by some and pluralism by others. Such a theory may well be impossible to formulate and may not even be desirable; but better information and sharper analysis for an aspect of human culture and society that has been and remains so central and influential are always beneficial and illuminating. As Western theories fail to account for the multivarious entirety of Chinese religious experiences, the incommensurability can effectively spur on scholars and researchers to investigate reasons for this. This essay is such an attempt. It explores a few of the reasons for the failure of Western theories to capture the Chinese case by examining the impossibility of asserting a straightforward claim, without exception, amid the historical and contemporary diversity of the three institutional religions (Confucianism, Daoism, and Buddhism), the continuous formation of popular religious movements, ever developing sectarian groups, and pan-Chinese quasi-religious practices like ancestor veneration, divination, healing practices and the like. It will also suggest a theoretical orientation of flexibility and indeterminacy based on indigenous ideas.

Why should this matter? Why should it be important still or is it already important to understand religion in its substance and functions in this nominally "secular", non-religious age? The reasons, it seems to me, are many. If we are to better serve peaceful ends, it is imperative that there is a firm understanding of religion in all its incarnations-for it continues to offer personal meaning and identity to some, define and motivate purposeful individual actions in others, and provides instrumental means for non-religious and even political ends for yet others. The process of how these private factors mesh with historical events and ideas help to shape our understanding of religion, and the varieties of this understanding have political impact. For the study of Chinese Religion(s), ${ }^{9}$ the challenge unexpectedly begins at variable categories found in Introduction to World Religions textbooks. Students of world religions often read about Judaism, Christianity, Islam, Hinduism, Sikhism, Buddhism but then encounter a different system of classification based on "nation" for East Asian Religions such as Chinese Religions, Japanese Religions, Korean and Vietnamese Religions. ${ }^{10}$ These disparate headings turn out

regulate, control, and exploit all rivalry (sic) religious traditions whenever it is deemed feasible and beneficial to the state." He argues that post-Mao "nationalism" becomes the transcendent. Citing Tim Oakes and Donald Sutton, he quotes from the introduction of their edited volume, Faith on Display: Religious Revival and Tourism in China: "The gods and churches are sponsored and in principle subsumed within the party-state-much as approved gods and religious institutions in imperial times were subsumed ideologically within the imperial metaphor and bureaucratically within the official system." (Liang 2014)

7 The agitation by and suppression of the Muslim Uyghurs and Buddhist Tibetans are illustrations of this.

8 The conversion to Christianity and the disavowal of traditional rites like funereal rituals by many Chinese is an example of this. I am not aware of any studies on the acceptance of coexisting Daoist and Buddhist funeral liturgies for Christian converts. Anecdotally, my experience within the Toronto Chinese-Canadian community is that while Daoist and Buddhist funeral practices are performed alongside each other, Christians often try to keep other family members from practicing them.

9 This is true also for other "ethnic" religions such as Japanese and Korean.

10 One wonders if one would speak about an English Religion, a Scottish Religion, a Welsh Religion, an Irish Religion, a British Religion, British Religions, or British Religious Traditions. And what might one include within them? Continuing as well as defunct pre-Christian contact Folk Religion and popular practices? Or Christianity only? 
to be unstable too, and just a few examples will suffice here. For example, Deborah Sommer uses Chinese Religion in the singular as the title of her book, following Arthur Freedman's position that there is one Chinese religion ${ }^{11}$, whereas Joseph Adler chooses "Religious Traditions" with the qualifier Chinese in the World Religions series edited by Ninian Smart, then uses Chinese Religion in the singular for Lindsay Jones (ed.), The Encyclopedia of Religion 2/e, and Chinese Religions in the plural once again in Jonathan Fenby (ed.) The Seventy Wonders of China; and finally, Daniel Overmyer applies the plural in Religions of China: The World as a Living System.

These first categorical and numerical "indeterminate" qualities depend, of course, on the tautological definition of religion and what institutions, ideas, and practices a theorist prioritizes. Scholars who focus on aspects of or specialize in the study of China are deployed here in an initial effort toward a theory of religion based on Chinese religious experiences. Sinologists like Robert Campany, Thierry Meynard, Michael Puett, Michael Szonyi, and Tan Soon Har have all noted that Chinese religious experiences fit badly into theories like secularization which have been drawn primarily from Protestant categories and experiences. Meynard reminds his readers that it was a rejection of their initial understanding of Confucianism as "natural religion," by their Dominican and Franciscan brethren, that led Jesuits to advance the idea of civil religion which eventually developed into notions of secularization. (2005) Szonyi extends the latter ill-fitting idea to include market and rational choice theories, writing that both can be found in pre-19th-century Chinese history and therefore are not a "modern" Western phenomenon. (2009) There is thus an odd twinning of the qualities of déjà vu and not-quite-right in the application of these ideas to the Chinese case. Further, Campany and Puett both note that early indigenous Chinese theories about ritual render Western sociological attempts-like Durkheim's to "unmask the true meaning of religion" as missing the point and oddly irrelevant. To better understand religious phenomenon, Puett argues for including early Chinese ritual theories to the reservoir of ones we already have. James Spickard, a sociologist of religion, goes further and asks proactively how a Chinese sociology of religion might expand current theoretical understanding by focusing on lay communities rather than formal organizations and individuals as current theories are wont to do (Spickard 2017).

Puett and Spickard's recommendations for the inclusion of indigenous theories are timely, for the current theoretical incompatibilities have notable consequences: they often mark Chinese Religion(s) as a theoretical outlier and may at times even contribute to misunderstanding about the state of religion in different Chinese communities, both native ancestral and diasporic. ${ }^{12}$ Elements that contribute to the anomalous case will be examined. First, there will be a brief outline of five pervasive informal Chinese ideas and attitudes that offer notable contrasts to the Judeo-Christian tradition; these are not representative of all Chinese religious experiences and they are chosen primarily for their contrastive quality. The focus on the popular will be followed by a discussion of classical Confucian theories about ritual through the works of Tan, Spickard, Campany, and Puett. The latter two scholars concentrate on Xunzi, with mentions of Confucius and Mencius, while Puett draws from the Liji (Book of Rites) too.

Second, there will be a very brief examination of how Daoist and Buddhist ideas generally reinforce Confucianism. Daoist ideas of complementarity and ineffability in the Daodejing and Zhuangzi will be the focus, along with Buddhist notions of emptiness and interpenetration, and the different qualities in the spiritual capacities of religious devotees. The latter will be read from Treatise of the Golden Lion, a work of the 7-8th-century monk, Fazang, and the very influential Mahayana Lotus Sutra

11 See (Freedman 1974). On the Sociological Study of Chinese Religion. In Ahern, Emily M., Arthur P. Wolf, \& Joint Committee on Contemporary China. Subcommittee on Research on Chinese Society. Religion and Ritual in Chinese Society. Stanford, California: Stanford University Press. Maurice Freedman was a well-respected 20th-century Sinologist and British anthropologist.

12 Szonyi writes that "it becomes evident that it is unproductive to discuss issues such as whether there is religious freedom in China without attending to the historical process through which the notion of religious freedom emerged there." (Szonyi 2009) See also Woo (2019), Religion and Politics in the People's Republic of China: An Appraisal of Continuing Mistrust and Misunderstanding. 
respectively. Together with Confucianism, they could form a basis for a theory of religion that is predicated on complementarity, change, and differences. Finally, there will be an analysis of Meynard's account of the early Christian misreading of Confucianism and how this confused idea is repackaged and imported back into China followed by Szonyi's discussion of the wholesale purchase of secularism as a part of modernization by the People's Republic of China (PRC). The latter's rhetorical question: "is it any wonder that religion has become a target of political intervention?" will in turn be contrasted to Liang Yongiia's contention that the Chinese state has never been secular and has always controlled other religions in a "hierarchical plurality". This ideological circle offers a tantalizing suggestion that "Western" secularization theory originates in part from the East, so that its adoption by the PRC is a peculiar sort of homecoming. Globalization would therefore appear to be more deeply embedded than suspected in both the East and West.

\section{Shared Ideals and Assumptions}

\subsection{Common Notions in Popular Religiosities}

Traditional Chinese "popular (non-)theology" or prevalent religious attitudes ${ }^{13}$ drawn from Daoism, Confucianism, and Buddhism often contrast with monotheistic ones. Five will be covered here. First, there is a popular Chinese idiom which claims that "All religions ${ }^{14}$ teach people to be good,"15 carrying with it an implicit sentiment that it really does not matter which religion is professed. This belief may come from the pan-religious ideal of goodness and compassion found in ren or humaneness/goodness/benevolence/compassion in Daoism and Confucianism, and cibei often straightforwardly translated as compassion in Buddhism. There is also a sense that this goodness is discovered by its lack: that is, people need to be taught how to be good because they tend not to be good when left on their own. It is, therefore, often assumed that it is through moral education that a person becomes a responsible human being. ${ }^{16}$ There is a second interpretation of "lack" in the sense that "To be able to recognize or to know goodness, a lack of it is necessary." That is, goodness can only be comprehended when wickedness is experienced. The absence of goodness, however, does not seem to have generated a robust discussion on theodicy and the focus remains squarely on "the good". 17

13 For this section, I draw from three decades of reading and asking questions of self-confessed Daoists, Buddhists, practitioners of folk religions, agnostics, and atheists. I have had casual conversations and or formal interviews at temples, shrines, community functions, various universities, gatherings with family and friends, and elsewhere. Although I have never met a self-identified Confucian, Confucian ideals are often found in the person's conversation, whatever their (non-)affiliation is. See Woo (2010), Chinese Popular Religion in Diaspora: A Case Study of Shrines in Toronto's Chinatowns; and Woo (2016), Distinctive Beliefs and Practices: Chinese Religiosities in Saskatoon.

14 Ritual is treated here as a broad equivalent to Religion and includes informal practices like bowing three times when offering incense at a temple or in front of an ancestral altar at home, chanting and meditating alone or with others, placing a shrine at the foot of a tree, and visiting the grave of a dead relative to pay respects. More formal rituals could include state rites to Heaven and Earth, or public rituals of exorcism and renewal.

15 I am never quite sure what to make of this. When I point out that religions can be very destructive, I am told that violence and terrorism are deviant; that all religions in their most essential teachings, teach people to be good. When I push further and suggest that not everyone's "good" is the same, the response is often the silver rule: "Do not do to others what you don't wish to be done to you."

16 This is not universal and there are philosophical differences. Mengzi and Wang Yangming are two Confucian thinkers who believe that people are innately good; Yangming was especially leery of classical book learning that Zhu Xi advocated-he was influenced by Buddhism. Many Mahayana Buddhists also believe that ubiquitous Buddha Nature can be discovered not by formal education alone, but by meditation.

17 Confucianism may have influenced this orientation. As noted later in the article, Tan Soon Har argues that "The authority that has primacy in Confucian life is ... neither political nor religious, but moral ... " She goes on to say that "Confucians would deny the autonomy of both the political and the religious" because they "have a more holistic outlook that keeps together the moral, the political, and the religious to yield what they consider a truly satisfying existence within the continuity of the personal, the familial-social, and the cosmic-infinite." 
Consequently, there is no apparent prevailing equivalent to the notion of sin and "evil" suggested in the Genesis Fall. ${ }^{18}$

This theological hazy ${ }^{19}$ one-sidedness might easily be applied to Confucianism but of course it fails to capture teachings in Daoism and Buddhism, which will be briefly discussed later. Nevertheless, it leads us into a second widespread notion, which carries us into a tendency best described as "straddling", illustrated well by a fundamental belief that the world is at once orderly and patterned, and chaotically dynamic. ${ }^{20}$ This inclusive metaphysical inexactness likely comes from a supposition of change: that is, the belief in the inevitable transformation that comes from the co-existence of alternating opposites, of the complementarity of knowable sameness and unfathomable difference. The inclusion of two opposing elements is perhaps best represented by the first two hexagrams in the Book of Changes: ${ }^{21}$ qian (the creative and a symbol for Heaven) and kun (the receptive and a symbol for Earth) and the first chapter of the Daoist Daodejing (also Lao Tzu: Tao Te Ching). The former two symbols are said to generate through interaction the other 62 hexagrams - that is, all things in the universe thereby marking a theory of impersonal non-anthropomorphic-divine creation; the latter includes examples that point to the relative and dependent nature of existence:

The difficult and the easy complement each other;

The long and the short off-set each other;

The high and the low incline towards each other;

Note and sound harmonize with each other;

Before and after follow each other. (Lau 1963)

(And we might add:

The good and the bad stand by each other.

The saintly and the evil lean in to each other.)

Alongside these abstract ideas are ubiquitous personal tutelary gods and goddesses, and they belong to and are a part of the complex complementary world; a creator god such as the one described in Genesis, like sin and evil, is not as common in the Chinese religious landscape. ${ }^{22}$ The focus on goodness $^{23}$ and the presumption of constant transformation and complementary opposites mark two components of Chinese religious thinking that contrast the centrality of the wickedness or sinfulness of human beings and the absolute unchanging oneness of God in the monotheistic traditions.

A third distinctive aspect is the attention paid to the natural differences of individuals' characters, mental and physical abilities, and the life conditions they find themselves in, resulting in different levels of understanding and the need for different teachings. The differences that are accepted in the Chinese religious tradition allow for an especially broad range of syncretic beliefs and practices and affect the (non-)development of boundaries for orthodoxy and heterodoxy especially vis à vis folk religiosities. The 4th-century B.C.E. Confucian philosopher Xunzi talks about the natural difference among a sage,

18 James Spickard cites a story from the 20th-century anthropologist C. K. Yang: “A Baptist missionary urged a Chinese college student to repent, to which the student answered: 'I come of reputable ancestry, I have a good conscience, and I have always been strict about my moral responsibilities and conduct. How is it that I am full of sin?'" (Spickard 2017), from Yang, C. K. 1968. "Introduction." Max Weber. The Religion of China: Confucianism and Taoism.) However, it is also true that the Daoist Yellow Turbans introduced the idea of sin that is inherited from ancestors and Buddhism brought with it elaborate ideas of depravity, sins, punishment and hells.

19 An interesting parallel, perhaps, is the description of the sage in the Daoist Daodejing. He is described as "unadorned", "drowsy", "muddled", and "foolish".

20 On trivial matters, this is expressed by the response of "It's simply like that." The same response is offered for events ranging from life passage events like marrying, becoming a parent, to ravages wrought by a typhoon or getting hit by a truck.

21 The Book of Changes is a text for divination. It has 64 hexagrams with commentaries, and functions as a guide through the inevitable changes and transformations in human life and the natural world.

22 There are stories about the goddess Nü Wa creating human beings and Pan Gu creating the world, but these are understood to be folk tales, as they lack the credibility and gravitas of the Genesis account.

23 See Analects 12.19: "In administering your government, what need is there for you to kill? Just desire the good yourself and the common people will be good." 
a junzi (one of noble character), an official, and an ordinary person in their mental-psychological capacities to understand the meaning of ritual, ${ }^{24}$ and in a similar way, the Lotus Sutra explains the existence of numerous teachings within the dharma as necessary and unavoidable because of differential spiritual capacities of the faithful. ${ }^{25}$ The acceptance of a broad range of interpretations and contradictory teachings offers a sharp contrast to the monotheistic foundation built on one God, and one essential set of revealed and or divinely-inspired scriptures. ${ }^{26}$

There is a fourth element that Jeung et al. (2015) determines as liyi-that is, propriety or good manners and right action in relationships. These two pervasive paradigmatic virtues when combined with the universal ren, echo some of the values embedded in the "habits of the heart" that Bellah posits as part of the basis for a civil religion. They were likely some of the ideals that persuaded Jesuits to read Confucianism as a Natural Religion too. But the focus on benevolence, propriety and right action are distinctly this-worldly and secular as they govern civility in public and reciprocity in personal relationships without specific reference to Heaven, the divine or sacred. Herein lies a sharp difference in reaction to what appears to be "secular" values: Robert Campany writes that "Durkheim is more sensitive than Xunzi ... to a problem inherent in this procedure (of unmasking the function of religion): once society and its attendant moral code are stripped of the authority formerly lent them by religious symbols, and reduced to their 'rational nakedness,' whence comes their authority?" (1992) But for the Chinese, apprehended through Xunzi and the Confucians, the absence of "religious symbols" and the divine does not pose a problem because the virtues are predicated on this-worldly benefits of social harmony, physical security, and economic-political stability, not the enticement of salvation in a future existence. Moreover, many Daoists and Buddhists would point to their teachings on karmic consequences, which operate "naturally" without the intervention of a deity. ${ }^{27}$ In this sense, the Chinese understanding of virtues is predicated primarily on earthly benefits and function without a religious authority like God, and is therefore different from Bellah's idea of a civil religion that sacralizes the state. ${ }^{28}$

The values that led to the Jesuit misreading of dynastic Confucian China and the eventual conceptualization of a post-Christian or post-Religion civil religion, have in the People's Republic of China (PRC) morphed into "core socialist principles" billeted everywhere in both English and Chinese: ${ }^{29}$ prosperity, democracy, civility, ${ }^{30}$ and harmony for the country; freedom, equality, justice, and rule of law for society; and patriotism, dedication, ${ }^{31}$ integrity, and friendliness for the individual. These core socialist principles bring us to the last and fifth element within Chinese religious experience: broad acceptance that politics drives religion. Religious ideas and practices have been malleable and shaped to serve political interests. For example, Shangdi or Lord on High, the ancestral deity of the

24 Although this appears similar to the four levels of interpretation in Jewish exegesis, Campany and Puett show that Xunzi encourages the Confucian literati to interpret the rituals not as "true" but as indirectly training emotions and attitudes.

25 The Essential Lotus says: "For numberless kalpas in the past/countless Buddhas who have now entered extinction,/a hundred, thousand, ten thousand, million types/in numbers incapable of calculation-/such World-Honored Ones,/using different types of causes, similes, and parables,/the power of countless expedient means,/have expounded the characteristics of teachings." (Watson 2002)

26 There are undeniably thousands of Protestant sects, but they all confess and profess to believe in Jesus and the creator God of Genesis.

27 This is of course not quite right. Buddhism, and Daoism imitating it, both have salvational figures such as Amitabha, the Buddha of the Pure Land in the West.

28 Meynard notes that the Jesuit idea of civil religion is different from Bellah's. The latter assumes an intended formal sacralization of the state.

29 In the Chinese cities of Guangzhou and Hangzhou, for example, posters can be seen on the street and in the subway, and the surrounding villages.

30 Wenming are the characters in Chinese. They can be translated as enlightened, cultured, and civilized indicating good manners and kind consideration.

31 Jingye are the Chinese characters. They can be translated as dedicated to study and work or respect for school and work. The second character ye has a sense of profession, occupation, business, and course of study. 
Shang dynasty ${ }^{32}$ and personal tribal god was banished over three thousand years ago and replaced by the extra-tribal, impersonal, abstract Heaven by the Zhou dynasty (c. 1046-256 B.C.E.). The use of Heaven allowed the Zhou to more easily assert that they were given the mandate to rule: that is, the Mandate of Heaven was bestowed on them because of the failings of the Shang rulers. By claiming that they were chosen for their virtue, the Zhou gained an aura of universality sanctioned by the divine, thereby undermining all bounded sectarian religions, which would by definition be limited and narrow in their perspectives. ${ }^{33}$ In contrast to this political Confucianism and as if to illustrate the reality of complementarity and theoretical flexibility and indeterminacy, Zhao Litao points to an example that offers the exact opposite. He writes that "The syncretic and non-political nature of traditional Chinese faiths is best demonstrated in local communal religions, which combine beliefs and practices from Confucianism, Daoism and Buddhism and take the form of ancestor and protective deity worships, geomancy, exorcism, and prognostications." (2010) Chinese Religion(s) is at once demonstrably political and non-political.

In place of a specific focus on salvation, truth, charity, institutional affiliation and attendance, community, and unity in a loving God, Chinese religiosities seem to assume sectarian variations ${ }^{34}$ and are premised more on "general" principles shared by the range of elite, popular and folk traditions: the privileging of benevolence, assumption of change and complementary opposites, attention to differences in individual capacities and capabilities, reliance on propriety and right action to establish a secure and stable humane society, and acceptance of sacralized political power for universal good over sectarian religion for the good of only some. Is it surprising that theories emerging out of Judeo-Christian traditions that are guided by dogma and ritual practices derived from revealed and divinely-inspired scriptures from one divine source, which privileges institutional belonging and community, would be ill-fitted to Chinese experiences that are relatively unsystematic?

\subsection{Classical Confucian Theories of Ritual: Religious and Secular as Complementary and Integral to Each Other}

\subsubsection{Theoretical Ancestors: Being Religious yet Keeping Away from Gods and Spirits}

The preference for generic virtues like benevolence, propriety, and right action that has encouraged a reading of non-religiosity rests on Confucian theoretical foundations. The early generalization from a specific supernatural deity to a natural one from Shangdi to Heaven, and the use of the Mandate of Heaven that sets a pattern for political supremacy and the sacralization of the state are two elements that give an aura of civil religious secularism - they are a part of the Confucian tradition too. In turn, these two shifts that promote an interpretation of secularism are reinforced by another factor: the acceptance of the inscrutability of what lies beyond the human realm. Confucius asserts in the Lunyu (Analects) that knowledge is "To know when you know something, and to know when you do not know something." (2.17) As Tan Sor Hoon aptly notes, as Confucius recommends that one should "keep one's distance from the gods and spirits while showing them reverence," (6.22) and one disciple observed that the Master "did not speak of ... prodigies, force, disorder and gods," (7.21) Jilu, another one of his students, asked "how the spirits of the dead and the gods should be served." And Confucius

32 Shangdi, the Lord on High, was the god of the imperial family of the Shang dynasty. The Zhou naturalized this lineage transcendent into impersonal Heaven. Shangdi was then picked up by the Christians as a translation for "God".

33 Liang Yongjia contends that the current relationship between the political establishment and religions in the PRC is not so different from that of dynastic China. He writes: "The gods and churches are sponsored and in principle subsumed within the party-state-much as approved gods and religious institutions in imperial times were subsumed ideologically within the imperial metaphor and bureaucratically within the official system." He describes this as "hierarchical plurality": "a state encompassing religion, and the accordance of legitimacy between state and religions, as well as among religions." Zhao Litao agrees with Liang and describes the traditional relationship between the state and religion as "soft secularism". He states that "By and large, religion has always been weak vis a vis the state." (Zhao 2010)

34 A major contradiction in religious goals, for example, is the Daoist pursuit of longevity and even physical immortality in some cases in contrast to the Buddhist striving towards enlightenment and leaving behind the dusty world of suffering. This description, of course, overstates the difference. The genius of the religious faithful is in syncretizing/synthesizing not only Daoism and Buddhism and Confucianism, but also Islam and Christianity. 
replied, "You are not able even to serve man. How can you serve the spirits?" When Jilu, undeterred, pressed on and asked, "May I ask about death?" The answer he received was "You do not understand even life. How can you understand death?" (11.12) (Tan 2010)

Confucius does not confess agnosticism or atheism; one intuits that he simply felt that he did not know enough to speak intelligently about, or to decide on the issue of spiritual orientation. The reasons for not discussing religious topics notwithstanding, the relative paucity of writings on such subject matters in the classical Confucian tradition often misleads students of religion to characterize Confucianism as secular.

\subsubsection{The Ultimate Goal: Peace through Self-Cultivation}

What the Confucians do talk about is government and the role of self-cultivation-that is, the place of "refining one's person" in political success. In the Daxue (The Great Learning), ${ }^{35}$ listed as chapter 42 in the Liji, is the following:

In ancient times, those who wished to make bright virtue brilliant in the world first ordered their states; those who wished to order their states first aligned their households; those who wished to align their households first refined their persons; those who wished to refine their persons first balanced their minds; those who wished to balance their minds first perfected the genuineness of their intentions; those who wished to perfect the genuineness of their intentions first extended their understanding; extending one's understanding lies in aligning affairs. ${ }^{36}$ (Then in reverse order, the author repeats the famous eight steps towards world peace.)

Only after affairs have been aligned may one's understanding be fully extended. Only after one's understanding is fully extended may one's intentions be perfectly genuine. Only after one's intentions are perfectly genuine may one's mind be balanced. Only after one's mind is balanced may one's person be refined. Only after one's person is refined may one's household be aligned. Only after one's household is aligned may one's state be ordered. Only after one's state is ordered may the world be set at peace.

From the Son of Heaven to the common person, for all alike, refining one's person is the root. That roots should be disordered yet branches ordered is not possible. That what should be thickened is thin yet what is thin becomes thick has never yet been so. This is the meaning of "knowing the root." This is the meaning of "the extension of understanding." 37

The ultimate goal for "the world (to) be set at peace" without any specific reference to the divine would likewise seem secular to monotheists. This process towards peace begins with the individual. All persons should "balance their minds", be genuine in their intentions, extend their understanding of the world, by categorizing and studying or investigating things. In having disciplined themselves, they can then go on to "align" their household and to bring "order" to their states. The emperor may be the divinely appointed Son of Heaven who is the impersonal transcendent sacred, but everyone including the "common person" should take "refining one's person" as the fundamental: "the root." In this way, each person is integrated into their family, community, and the sacralized state.

James Spickard reflects this when he writes that contrary to theories of secularization, "Confucian thought is ... neither secular nor religious, but denies the validity of these conceptual categories." $\mathrm{He}$ suggests, correctly I think, that "a sociology of religion primed to pay attention to $l i$ and $d e$ (that is, virtue, of which benevolence and right action are two) would see congregations as ritual communities

35 The Liji or Book of Rites is an edited volume that dates from the Warring States to the Han dynasty (c. 400 B.C.E. to 9 C.E.). The tradition understands Zeng Shen (505-436 B.C.E.) to be the author of the Great Learning. Western scholars believe that the authors are unknown.

36 "Aligning affairs" is often also translated as "investigation of things".

37 See Eno (2016). The Great Learning and The Doctrine of the Mean: An Online Teaching Translation. http://www.indiana. edu/ \{\}p374/Daxue-Zhongyong.pdf (accessed 28 March 2019). 
and put community-building at the heart of religious activity," and consider the "biological ties of the family" and society as sacred. Tan Soon Har goes so far as to argue that Confucians "have a more holistic outlook that keeps together the moral, the political and the religious" in contrast to Western secularist philosophies that try to separate religion from politics. A fulfilment of the Mandate of Heaven after all rests on discernible evidence: the existence of a safe, stable, and thriving empire or country. That is, the emperor and his ministers must rule well so that the country is peaceable, prosperous and secure, and the people happy and well-sustained.

The formal integration of religion and politics first happened over two millennia ago as Confucianism became the state religion during the Former Han dynasty in the 2nd century B.C.E., ${ }^{38}$ it not only formed an influential primary institutional reference, but it also represented a complementary and competing tradition for other religions. The ascendance of Confucianism above other religions happened toward the completion of the compilation of the Liji, almost half a century after Confucius (551-479 B.C.E.), Mencius (c. 372-289 B.C.E.), and Xunzi (c. 310-c. 238 B.C.E.) ruminated and wrote about the meaning and function of ritual.

\subsubsection{Confucius and Mencius: The Germ of Ritual Theory}

It would be impossible to trace or to measure the exact effect that Confucian ritual theories have had on the development of Chinese society and religion. It would not be unreasonable, however, to assume that the Confucian discussion about human provenance and patterning of rites helped to shape state policies towards religions and folk religiosities, which in turn affected the development of the religious landscape.

In the 6 th century B.C.E., Confucius took the ancient rites of the Zhou dynasty and recast them not as rituals to appease or to praise supernatural beings, nor as magical solutions to natural phenomena like drought and flooding but as Campany writes, he interpreted them instead as "a medium for the cultivation of one's inner dispositions and for the perfect expression of one's humanity." When asked about the Zhou ancestral Ti sacrifice, Confucius admitted that it was not something he understood; but a person who did know the meaning of the rite, he said, would be able to govern the empire effortlessly (see Campany and Tan). Mengzi, following the Master's humanistic orientation, taught that $l i$ starts in the natural attitude of respect and modesty, one of the four duan (beginnings) of human nature which he presumed to be innately good.

Xunzi, following Confucius' advice to "Sacrifice to the spirits as if the spirits were present" (3:12) arrived at a very different interpretation (see Campany and Puett). He came to believe that rituals were developed by sages: that is, persons who were capable of "governing the empire effortlessly" as Confucius had indicated. That rites are humanly created and do not have divine origins was thus established definitively. Following Confucius, Xunzi affirmed that they were created "to train human desires, to express human emotions, to give structure and coherence to human society, to provide a total cultural habitat in which virtue and wisdom can flourish (Campany 1992)." Given the focus on peace, self-cultivation, and the unfathomable meaning but the continued performance of at least some of the rites, Tan insists that

In Confucianism, the political is subordinated to the moral, and the religious is accessible only through a significant level of moral achievement. (Emphasis added.) Human beings must focus their attention and effort on the moral (self-cultivation), and the rest will fall in place. The authority that has primacy in Confucian life is therefore neither political nor religious, but moral.

As Tan interprets it then, it is not that Confucianism is not religious but that, "religious commitment is a continuation of moral commitment" at a higher level. The central task for a Confucian is not to

38 This was during Han Wudi's reign (r. 141-87 BCE). 
gain salvation for themselves in a dogmatic afterlife but to build a harmonious society for everyone through ethical engagement, before all else. A secular worldly goal this may seem, but it is predicated on the Mandate of Heaven.

\subsubsection{Xunzi and the Liji: The Development of Theory}

Tan's notion that "the religious is accessible only through a significant level of moral achievement" suggests that she understands "religious" differently from Xunzi. Whereas she believes that religion develops out of moral and implied spiritual cultivation, Xunzi believes that while the meaning of ritual $^{39}$ is unknowable, common people typically associate them with the supernatural. ${ }^{40}$ Nonetheless, he writes that rites should be maintained because they act as a kind of social adhesive, discouraging instability. Regardless of the apparent differences between Tan's 21st-century interpretation in contrast to Xunzi's 4th-century B.C.E. understanding, Confucianism is shown to be notably different from monotheistic traditions when the function of religion is considered alongside all the elements discussed in the previous sections. ${ }^{41}$ Moreover, there is in the Li Yun chapter of the Liji, ideas that further corroborate Spickard and Tan's understanding that Confucianism assumes both religious and secular qualities.

While the rules of ceremony have their origin in heaven, the movement of them reaches to earth. The distribution of them extends to all the business (of life). They change with the seasons; they agree in reference to the (variations of) lot and condition. In regard to man, they serve to nurture (his nature). They are practised by means of offerings, acts of strength, words and postures of courtesy, in eating and drinking, in the observances of capping, marriage, mourning, sacrificing, archery, chariot-driving, audiences, and friendly missions.

Thus propriety and righteousness (liyi as discussed by Jeung et al.) are the great elements for man's (character); it is by means of them that his speech is the expression of truth and his intercourse (with others) the promotion of harmony ... (Rites) constitute the great methods by which we nourish the living, bury the dead, and serve the spirits of the departed. They supply the channels by which we can apprehend the ways of Heaven and act as the feelings of men require. It was on this account that the sages knew that the rules of ceremony could not be dispensed with, while the ruin of states, the destruction of families, and the perishing of individuals are always preceded by their abandonment of the rules of propriety. (Legge 1885)

With the recognition that "the rules of ceremony have their origin in heaven," Confucianism is undeniably religious in spirit. Yet these rules also serve seemingly secular ends, as they help to nurture human nature to stave off disorder by encouraging honesty and harmony. And, in contrast to monotheism, rituals are important the Liji offers, because when rites are abandoned, it is the state that is imperiled not one's personal eternal life.

Robert Campany believes that theories about rites had started to bubble up beginning in the 6th century B.C.E. because ritual performances had become "peculiarly problematic or opaque" and needed "interpretation or explanation." Puett determines that for Xunzi and the early literati, "Rituals were attempts to domesticate humans and help them forge better relationships with each other." Xunzi and the Confucians were not unique in their interest in theory; other contemporary ritual theorists included Daoists, Legalists, Mohists and Logicians. Daoists understood ritual in terms of natural

39 Demonstrated here is the need to clarify which aspect of religion is considered. Tan seems to be thinking of what would likely fall under "theology", whereas Xunzi is clearly referring to naïve indigenous beliefs and practices.

40 An analogy might be made between that the sage who developed the rites in Xunzi and Tan's higher level of religion achieved through moral cultivation. Such a comparison is unfortunately beyond the scope of this article.

41 These include virtues, transformation, complex complementarities, varying spiritual and intellectual capacities, authority of impersonal Heaven as ultimate, limits to one's knowledge, importance of self-cultivation for every individual, and most importantly the absence of discussions about the divine and an afterlife. 
processes, Legalists in reward and punishment, Mohist in social utility, and Logicians in linguistic analysis. Perhaps not unlike Western theorists during the 19th and 20th centuries, these classical Chinese thinkers moved beyond the rituals themselves and assumed a "kind of cognitive distance" from them and so moved from theological to what Campany describes as "performative ground." While the widespread attention to the principles for ritual performance over two millennia ago presents intriguing opportunities for inter- and intra-cultural comparisons, we will focus on Confucianism here.

Like Puett, Campany argues that for Xunzi, from "the point of view of the human community, ritual functions to reinforce social hierarchy and maintain social order." In fact, Xunzi points out that "Sacrifice is a great benefaction. When superiors receive some benefit, they then bestow it on those below them. It is just that superiors receive the beneficence first and subordinates receive it later; it is not that superiors accumulate excess while subordinates suffer from cold and hunger." (Sommer 1995) From this vantage point, "superiors" and "subordinates" are understood primarily in social terms: a deeper equality and sharing of material wealth are assumed. Here, ritual appears to symbolize what we might understand to be something like income redistribution through fair and presumed "trickle-down" economics. That is, "sacrifice" represents an ideal of fair economic allocation of material assets.

In this way, Xunzi tells us that the "rules of ceremony are the embodied expression of what is right. If an observance stands the test of being judged by the standard of what is right, although it may not have been among the usages of the ancient kings, it may be adopted on the ground of its being right." But what is "right"? What is "right ... makes the distinction between things, and serves to regulate (the expression of) humanity (ren) ... Humanity is the root of right, and the embodying of deferential consideration." Distinction is, therefore, crucial. If it were absent, Xunzi believes, people will fight over goods that are scarce and go to war with each other.

The focus on "natural" social distinction is clearly different from the monotheistic notion that all are equal before God. The hierarchy of superior and subordinate are recognized in tandem with the understanding that the former is obligated to share resources with the latter. That is, "that superiors (are not to) accumulate excess while subordinates suffer from cold and hunger." If superiors should accumulate excess and let subordinates suffer, then some of the primary ritual functions-the fair distribution of goods, preservation of harmony, and prevention of strife and conflict-would be violated. But not everyone would understand this. In fact, Xunzi was convinced that

Only a sage can fully understand ritual. The sage has a clear understanding of it, the gentleman finds comfort in practicing it, the official takes it as something to be preserved, and the common people accept it as custom. To the gentleman it is the way of being human (ren dao); to the common people it is a matter of serving spirits (and ghosts). (Watson 1963)

The Chinese religious universe that is so jampacked with countless popular movements, sectarian groups, and folk beliefs and practices is likely a result of these assumptions: religious beliefs and practices, old and new alike, need not or perhaps even ought not be reined in because ordinary people cannot help themselves - they will always need or want to believe in the supernatural, as in "serving spirits." Since sages are understood to be the human originators of ritual that in turn have their "origins in heaven", it is not surprising that "early Chinese practices involve an explicit attempt to transform the divine into forms that resemble those found in society" in order that they could be more easily absorbed and properly performed (Puett 2013).

The various Confucian theories are thus, as Puett defines them, "explicitly humanistic, but not in a debunking sense." Rather, they have everything to do with the domestication of "both the human and divine realms" and they are seen as necessary for human society to flourish. As Puett so forcefully attests, "the divine order itself appears to be fully contingent (on a particular local community), and explicitly dependent on the social arrangements that are quite openly seen to be such, and the divine is explicitly seen as being defined by these contingent social relations." So, if we take Durkheim's radical insight that "The sacred ... is society in disguised form" and apply this to Xunzi and the 
Confucian tradition, Puett asks, "what are we to unmask, if the practices are already explicitly doing what we would want to unmask them doing?" That is, what is there to unmask when ancient theories tell readers openly that Confucian rituals are intended as indirect means to tame human beings by theory and design ${ }^{42}$

Even as Durkheim and Xunzi seem similar, there are important differences, as both Campany and Puett point out. Confucianism recognizes a given-ness (Heaven here for simplicity's sake) that is beyond human understanding and control. However, an admission and declaration of ignorance, and a willing acquiescence to the limits of our minds do not mean that the divine is abandoned, as both Spickard and Tan clearly demonstrate. For Confucians, therefore, the sacred that is perennially bound up with existential questions is always assumed, and the central challenge lies in finding the best way to live well by oneself and with others given the pattern of nature (Heaven and Earth). Or as Buddhism would have it: we are born, we become sick, we grow old, we suffer and then we die. The challenge of our lives is to understand the essential markers of no-self, impermanence, and unsatisfactoriness and discover ways to transcend the samsaric world. As different as this perspective is from the two indigenous Chinese traditions, it has served as complement to Confucianism both on the personal and communal-state levels, and inspiration and standard for Daoism.

\subsection{Potential Buddhist Contributions to Theory}

The struggle to understand and the effort to theorize about the meaning and function of ritual are absent from Buddhism. Buddhist philosophy, nevertheless, has much to contribute toward a theory of religion based on Chinese experiences. As different as Confucian and Buddhist teachings might be, two similarities stand out: self-cultivation and the aspiration to help others-in the "town marketplace" rather than in government, in Buddhism's case.

From the iconoclastic Meditation (Chan) School, there is the Ox-Herding story which helps to explain some core ideas in Buddhism. The narrative begins with a seeker, the oxherd, who believes that they (the self) and the ox (the "ultimate, undivided reality") ${ }^{43}$ are different and separate. They begin by searching for the ox, see its hoofprints, catch sight of the ox, struggle with it and catch it, tame it with whip and rope, get up onto the ox and head home, abandon whip and rope as rider and ox settle in at ease, then they realize the unity of all things including whip and rope, understand the nature of things as they are, and finally return to the "town marketplace" like an ordinary person but with the extraordinary and profound awareness of things-in-the-world-as-they-are (Koller n.d.).

Koller writes that the ox symbolizes the ultimate, undivided reality, Buddha-nature, which is the ground of all existence. The oxherd in turn symbolizes the self, who initially identifies with the individuated ego, separate from the ox, but who through discipline and with progressive enlightenment, comes to realize the fundamental identity with the ultimate reality which transcends all distinctions. When this happens, the oxherd realizes the ultimacy of all existence and that there is nothing that is not Buddha-nature. For our study here then, the sacred is not different from the mundane. The oxherd- that is, the seeker and religious faithful—now understands the preciousness and profundity of the most ordinary things of life, illuminating ordinary living with his enlightenment.

42 Drawing from a personal anecdote is the following story. In the 1950s, in a wealthy, well-educated, Nationalist Party sympathizing, Shanghainese Chinese family in diaspora in Melbourne, the teenaged third daughter asked her father why they should continue to practice ancestor "worship" when it is clearly superstitious and has no scientific basis. Her father replied that the better term to use is not worship but veneration, and that the spirits may not really exist but the ritual is performed out of respect and memory of where you come from.

43 The Ox-herding pictures are used as metaphor for teaching about the stages of spiritual training through meditation, a disciplining of the mind. This is one part of the traditional three trainings, which also include an adherence to clerical rules for monastics or precepts for laypeople, and the cultivation of insightful wisdom. 
In contrast, Fazang (643-712), the influential third patriarch of the Huayan school, approaches the core Sino-Mahayana concepts of emptiness ${ }^{44}$ and interpenetration ${ }^{45}$ philosophically. His Treatise on the Golden Lion illustrates well these Buddhist notions. Fazang teaches that a lion made of gold comes into being because a craftsperson creates it. The lion like the oxherd or seeker is the self, and the gold is Buddha Nature. Each part of the lion is distinct, yet each also establishes the presence of the rest. The gold could of course be melted down, then the form of the lion will no longer exist and only the gold or Buddha Nature will remain. The lion's existence is therefore contingent, but the gold is not. Fazang says that

The lion represents the character of wholeness, and the five organs, being various and different, represent diversity. The fact that they are all of one dependent-arising ${ }^{46}$ represents the character of universality. The eyes, ears, and so on remain in their own places and do not interfere with one another; this represents the character of particularity. The combination and convergence of the various organs makes up the lion; this represents the character of formation. The fact that each organ remains at its own position represents the character of disintegration. (Fazang n.d.)

The craftsperson's preconditioned conception of what a lion is, their skill, and the whole and the parts of the sculpture together form the eventual shape of the lion. Applied specifically, one might say that Chan Buddhism arises and takes the form it does because of the presence of Confucianism, Daoism, and other factors like the spiritual needs of human beings who suffer. Fazang continues to say that "when we look at the lion, we see at once that all conditioned things, without going through the process of disintegration, are from the beginning in a state of quiescent non-existence." That is, they do not exist until they come into existence through dependent arising. "By being free from both clinging and detachment, one can ... comprehend the fact that from the very no-beginning" the lion comes into being from the conditioned origins of many elements including the gold, the craftsperson, and the accepted norms of what a sculpted lion should look like. In this way, misconceptions, misapprehensions, and "all illusions are in reality non-existent." That is, they are all conditioned, subject to the influence of other elements around them. For Fazang and Buddhists, when the interrelated and conditioned nature of all things is realized, that is "Enlightenment."

In the context of a theory of religion, the ideas of emptiness and interpenetration would suggest that religion and secularism co-arise out of ignorance, an erroneous belief that phenomenal elements are separate and independent from each other. This understanding, not unlike Spickard and Tan's assessment of Confucianism's contrastive difference especially from many theories of "hard secularism", would probably lead many Buddhists to view religion and secularism as part of a particular ideological formation, related to and defined by each other. In that sense, both ideas are "empty": that is, lacking in stand-alone, independent meaning and are devoid of universal, definitive, unchanging characteristics. So, if according to Chan, everything is Buddha-nature, ${ }^{47}$ there is no need for orthodoxy or to grasp onto "right" belief and practice and hold exclusively to Buddhist teachings. For different reasons then, both Confucianism and Buddhism have accepted other teachings and their interpretations of "reality." They have in the main coexisted easily historically, accepting and contributing to each other's development and along with Daoism, generating many sectarian movements, creating a religious landscape that is markedly different from the monotheist West.

44 Emptiness refers to two core ideas in Mahayana Buddhism: that all things are composite-that is, made up of different elements; and that they are impermanent-that is, they change over time.

45 To explain the idea of interpenetration, Fazang is said to have put a statue of a golden lion at the centre of a room with mirrors on all the surfaces, thereby showing the infinite reflections of the form of the lion.

46 That is, simply put, the lion arises because there is an idea of a lion, the interest in seeing a lion, so when a form of the lion arises, the five organs (among other body parts) are generated as a part of it.

47 Theravadins do not believe this and not even all Mahayana Buddhists agree. The Faxiang (a branch of Yogacara) school believes that there are people, icchantikas, who are so completely devoid of any good roots that they are doomed to eternal samsaric existence. 


\subsection{Potential Daoist Contributions to Theory}

Like Buddhism, the struggle to understand and the effort to theorize about the meaning and function of ritual are absent from Daoism too. Like Buddhism, Daoism has much to contribute to potential theories about religion too. The first chapter from the Daodejing under the section on "Common Notions in Popular Religiosities" reveals an orientation towards complementarity. This second indigenous Chinese religion, ${ }^{48}$ like Confucianism and a sinicized Buddhism, includes an integral component for self-cultivation. But the spiritual adept is not a Confucian sage or junzi intent on bringing peace and harmony through government, nor are they a pusa or bodhisattva (an enlightened being who defers enlightenment to aid others) who ferries suffering beings to liberation; the Daoist Holy Man (and in the Zhuangzi, he is a man) is instead described as living far away from human society. His skin is "like ice and snow" and he is "gentle and shy like a young girl."

He doesn't eat the five grains, but sucks the wind, drinks the dew, climbs up on the clouds and mist, rides a flying dragon, and wanders beyond the four seas. By concentrating his spirit, he can protect creatures from sickness and plague and make the harvest plentiful. (Watson 1968)

There is a fantastic quality to this Holy Man. Zhuangzi mixes magic and mystery into philosophical ruminations and it is difficult to know when he is serious. But like the oxherd, the Daoist sage is careful not to make radical distinctions. In his famous passage on "this" and "that", Zhuangzi says this about the sage:

Everything has its "that", everything has its "this". From the point of view of "that" you cannot see it, but through understanding you can know it ... [The sage] illuminates all in the light of Heaven. He too recognizes a "this", but a "this" which is also "that", a "that" which is also "this". His "that" has both a right and a wrong in it; his "this" too has both a right and a wrong in it. (Watson 1968)

Resonating with Buddhist emptiness and Daoist complementarity, Thierry Meynard, a Jesuit Sinologist and scholar of philosophy writes that "We should recognize that the boundary between the religious and the secular is not as rigid and absolute as we have thought, but a changing reality in history." He refers to the Jesuit theologian, Henri Bouillard, who uses the term "holy" to bypass "the binary opposition between religion and secularity" and writes that "the holy is an element of the profane, where the religious human being recognizes the echo of the divine, and by which he expresses his personal relation, as well as the whole profane's relation to the divine." (Meynard 2005)

A theory that takes seriously Buddhist and Daoist ideas discussed above would easily support Meynard's insight that religion is dynamic and not lived through "a theoretical belief in dogmas but as a life experience in which the divine makes itself manifest." (Meynard 2005) And if we substitute religion and secularism for "this" and "that", we find again a natural reasoned preference, as in Confucianism and Buddhism, for understanding the two concepts as related and or embedded in each other. As for Confucianism, Zhuangzi criticizes its positive virtues as "false adornment". Yet, on one occasion, signaling agreement or perhaps cheeky fellowship, he puts the following words on meditation and self-cultivation into Confucius' mouth:

Make you will one! Don't listen with your ears, listen with your mind. No, don't listen with your mind, but listen with your spirit. Listening stops with the ears, the mind stops with recognition, but spirit is empty and waits on all things. The Way gathers in emptiness ${ }^{49}$ alone. Emptiness is the fasting of the mind. (Watson 1968)

48 For our purposes here, the focus will be exclusively on Lao-Zhuang or philosophical Daoism that forms one foundational stratum of a boundless complex of multitudinous variations within religious Daoism.

49 This Daoist emptiness refers to vacuity, like the hollow of a bowl, and is quite different from and not to be confused with the Buddhist emptiness which involves the concepts of no-self and impermanence. 
By the end of the fourth and the beginning of the fifth centuries, religious Daoist schools like Numinous Treasure adopted wholesale Buddhist teachings, institutions, and practices. Daoists took on swaths of "excellent" elements from Buddhism while retaining its prime foci on health and longevity, sharing with Confucianism the ethos proclaimed in the Liji, which declared that "what is right, (even though) it may not have been among the usages of the ancient kings ... may be adopted on the ground of its being right." In this way of thinking, if a new idea, method of cultivation, or institutional structure could bring succor and joy to people, accepting it is only sensible. If this seems unprincipled and inconsistent, the first two lines of the Daodejing offers some insight into the Daoist approach to inter-religious encounter: "The dao (way or path) that can be taken or spoken is not the constant Dao. The ming (name or title) that can be named is not the constant ming." In short, things change. Speaking and naming are human activities that are limited and limiting; even if there were Eternities, The Way or The Name (or Sign) could not be captured in the mortal realm.

\subsection{Shared Fundamental Pluralism: Assumptions of Difference and Diversity}

Like Daoism, Buddhism accepts the plethora of different teachings without resorting to parsing dogma for orthodoxy and heresy, but they explain the diversity of views more instrumentally. In the Lotus Sutra, the historical Buddha justifies his inconsistent teachings as "expedient means"; that is, he explains that he tailors them to the nature and capacities of his audiences. To his disciple, the elder Shariputra, he remarks: "Shariputra, you should understand this./The Law of the buddhas is like this./Employing ten thousand, a million expedient means,/they accord with what is appropriate in preaching the Law./Those who are not versed in the matter cannot fully comprehend this./But you and the others already know/how the buddhas, teachers of the world, accord with what is appropriate in employing expedient means (Watson 2002)."

Diversity and perhaps even a conscious pluralism in the historical and contemporary coexistence of institutional, popular sectarian, and folk religiosities ${ }^{50}$ are obvious characteristics of the Chinese religious landscapes: all three religions contribute to them albeit in different ways, as described above. All three religions also assume a pre-modern sense of the embeddedness of religion in all facets of life. Xunzi assumes the need for rituals because of wicked human nature and the need for domestication; Laozi's statement about ineffability assumes an ultimate Way and Zhuangzi's "this" and "that" assumes that the Way and its attendant Abiding Truth is never one-sided; Buddhism, on the other hand, assumes primordial ignorance and unsatisfactoriness to be so deeply rooted in human beings that it accommodates suffering beings with innumerable teachings. These insights notwithstanding, the disastrous and humiliating encounter with the West beginning from the mid-19th century resulted in wholesale attempts to disestablish religions in mainland China. There were two exceptionally devastating periods of destruction: the first happened during the New Culture Movement in the mid-1910s to 1920s amid the nascent Republican era, and the second during the Cultural Revolution amid the early Communist People's Republic era. The institutional religions and their syncretized popular and folk derivatives were put under extreme pressure.

\section{Secularism and Other Theories: Easternization and Westernization?}

Current Western theories fit badly and do not explain the Chinese case because of differing assumptions, histories, beliefs, and resulting practices. This mismatch is not in itself a problem: the tendency or ambition to build a determinable universal theory is. On this, Spickard quotes Bill Ashcroft, who states that "Universalism offers a hegemonic view of existence by which the experiences, values, and expectations of a dominant culture are held to be true for all humanity." Meynard rues the fact that people have, ironically, forgotten that "the process of universalization first happened

50 This pluralism is especially true of the islands of Taiwan, the Republic of China and Hong Kong. The political ecology makes the situation on the mainland People's Republic of China more complex. 
in the contingencies of an historical encounter between different cultures trying to overcome their differences." He traces the origins of secularization theory back to a Jesuit misreading of Confucianism and its place in Chinese government and opines that "without the Chinese concrete example of a society that was at once both a-religious and virtuous, the Enlightenment could have not imagined such a society ever being possible." 51 Like the French Sinologist, Joël Thoraval to whom he refers, Meynard argues that the secular culture of China made an "important contribution in shaping the modern concept of religion," for China offered to Enlightenment thinkers like Voltaire, an example of "a society without a revealed religion and without a church," and in so doing set Western cultures on a path toward secularism and theorizing about secularization. Since secularization theory in part emerged from a misunderstanding of a particular historical situation and was developed specifically in the West, it is unclear to me if its broad universal claims at this time, in its current iteration, can yield reliable data and prognosis.

But strategic scholarship can meet the challenges of incommensurate secularisms and deficient theories. Deeper cross-cultural and inter-cultural understandings of secularity and religiosity in contemporary cultural China should be possible. ${ }^{52}$ To this end, Szonyi recommends a theory of Chinese secularization that encourages "placing the history of Chinese religion in the global context of the reinterpretation of religion in response to the globalization of European ideals". He further suggests the analytical categories of "political" and or "civil" religion that emerge out of research by other sinologists ${ }^{53}$ who have picked out strands of "millenarianism and exorcism" from Maoism. ${ }^{54}$ Szonyi's choice of civil religion is especially interesting: for as with secularization, the idea brings our discussion full circle, back to the missionaries. For it was the Jesuits who created the concept of "civil religion" predicated on an empire or country ruled through non-religious principles and governance. The first generation of Jesuits had astutely observed and understood Chinese rituals to be "naturally religious," but the Dominicans and Franciscans had disagreed and insisted that the rituals were false because they were not Christian. So, to distinguish Chinese practices from the "real" religion of Christianity, the Jesuits compromised and introduced the category of civil religion.

The early Jesuit depiction of the Chinese "social and intellectual elites as secular rationalists" is called into question by Szonyi, who cites recent studies of "religious and ritual dimensions of Confucianism and the state cults and the engagement of the elite with other elements of the religious marketplace $" 55$ as evidence against the characterization of the traditional Chinese literati and other elite as rational. Whether the elite can properly be described as "secular rationalists", it seems to me, depends on how religion and secularism are defined, which elites were encountered and described, and what social or political occasions they performed in. As an alternative source to historical accounts, participant responses from contemporary interviews ${ }^{56}$ conducted with diaspora Chinese in Toronto and Saskatoon suggest that for non-Christians who have had some experience or acquaintance with traditional culture, religious and secular sensibilities are not independent and isolated from each

51 This is impossible to say. The Chinese society idealized by the Roman Catholic missionaries and Enlightenment thinkers was an imaginary one. The missionaries could very well have invented the idea from some other circumstance. The crucial point is that China was a factor in the conceptual development of secularism and the misunderstanding has relevance in understanding the current place of religion in the world.

52 "Cultural China" refers to the People's Republic of China, the Republic of China (Taiwan), and the multiple Global Chinese diasporas.

53 Szonyi includes the works of Geremie Barmé, Shades of Mao; Stephan Feuchtwang and Mingming Wang, Grassroots Charisma: Four Local Leaders in China; Barend Ter Haar, "China's Inner Demons: the Political Impact of the Demonological Paradigm" in China Information; and Zuo Jiping, "Political Religion: The Case of the Cultural Revolution in China" in Sociological Analysis.

54 There has been a long history of millenarianism in political movements encouraged by religious beliefs. Early examples include the Daoist-inspired Heavenly Masters and Yellow Turbans from the Han dynasty; and later examples include the White Lotus and the Taiping rebellions during the Qing. Exorcism is still current in folk practices.

55 I cannot speak specifically to this as I do not know which studies Szonyi refers to. I would say generally that there are different notions as to who the "elite" are. I believe that Xunzi is speaking about mental and psychological capacities and not what we would call categories of socio-economic class when he describes the four groups. In other words, a very poor scholar or carpenter might be construed as junzi, while an extremely wealthy "official" may in fact be a very ordinary person.

56 The choice of interviewees is the crucial factor here. I look forward to more scholarship on this in the future. 
other-they can very easily coexist. (Woo 2010, 2016) To reference Zhuangzi very loosely, "this" and "that" are not merely oppositional complements that only stand side by side, they live in each other.

As for the findings of millenarianism and exorcism in Maoism amid a "secular" Communism, Xunzi appears to have been correct in his assessment of ordinary people and their understanding of the world in terms of ghosts and spirits, and thereby offer a stronger prognosis than theories on secularism; natural, political, and or civil religion; and market and rational choice theories. Szonyi unsurprisingly finds also that core theoretical subjects like differentiation, political supremacy over religion, privatization, and freedom of choice that are postulated to indicate modernity in western theories all find precedence in Chinese history. Further, he finds evidence that contradicts the theory of incremental secularism in the "unexpected" popularity of spiritual practices for the Falungong in the PRC, 57 and the "deprivatization" of religion in Taiwan where religious groups have abandoned the "assigned place in the private sphere and (now enter) the undifferentiated public sphere of civil society" and in the process provides a means through which to criticize the government. Once again, Xunzi's theory on the function of religion variously interpreted, offers a plausible explanation to the different status and roles of religion for a variety of groups in contemporary Chinese societies.

Both Meynard and Szonyi speak to the profound effect that western concepts about religion, science, and democracy have had on China: one of the most extreme and detrimental case is, of course, the brutal suppression of religion during the Cultural Revolution. Meynard reminds his readers that though the concept of religion "indeed came from the West ... (it was) as a Western response to Chinese reality." The moral of the story here seems to be this: the misunderstanding of China-of its religion in this case, by the West and the Chinese themselves, happened from the very beginning four hundred year ago and has continued till the present. So, it is all the more important to remember Szonyi's insight that

Recognizing that secularization even in its more restrictive forms is a highly contingent process (that is "the very measures themselves turn out on closer analysis to be culturally specific rather than universal") will shape other debates as well. For example, it becomes evident that it is unproductive to discuss issues such as whether there is religious freedom in China without attending to the historical process through which the notion of religious freedom emerged there (2009).

He continues to say that the PRC's policy and treatment of religion are "inevitably" evaluated by western analysts through what would be considered the "legitimate exercise of power." But the mainland government's measure of legitimacy is not "respect for individual rights" alone, as the prominence of human rights in the West might suggest but includes "the pursuit of nationalism and modernization." That is, PRC national interests concentrate on freedom from foreign incursion and achievement of a prosperous and stable country. This sounds remarkably like the goals of governance stated by Xunzi. Could be that religion, as predominantly defined by Protestant theorists, is simply not important to the PRC government-just as it has not been central to dynastic China in the way that revealed teachings have been core to much of the experiences, politics and histories of the monotheistic West? If so, are the PRC's recent policies and actions encouraging religious charity work simply a pragmatic response to the reality of religious development in the country rather than a shift in theoretical perspective? And what does all this mean for a flexible, indeterminate theory of religion?

\section{Towards a Sociology of Religion Based on Chinese Experiences}

A sociology of religion based on Chinese religious experiences would start from assumptions that are different from monotheistic ones. Here are some. Religion may not always be easily identifiable or

57 One magical practice here is the calling on the master to heal one's illness while meditating on the revolving dharma wheel (falun) in one's abdomen. 
valued for its inherent worth even in a nominally religious society. It will not have one sole universal function and may provide calm and refuge for some, a means of comfort and escape for someone else, purpose to another, and instrumental means to yet others. It has been shaped by multiple perspectives, and mental and spiritual competencies, and can refer to a breadth of phenomena that ranges from formal institutions and dogma, to folk religiosities that for example attend only to life cycle rituals and lack permanent structure. It can be used politically within a secular environment or it can be the foundation for government. It can foment rebellions and revolutions against the state, or it can be used to establish a nation. It can be expansive and inclusive, or it can be restrictive and exclusive. It can offer common values and goals and help to foster a stronger community, or it can reinforce questionable and irrational ideas and practices and bring disintegration.

Approaches to understanding religion using Chinese experience would acknowledge important insights and contributions made by both indigenous and western, and classical and contemporary theorists. Like Chinese Religion(s) itself, such theories would likely seem unorganized and they would probably be syncretic. They would recognize differences in human nature, capacity, and capability which necessarily infer different interpretations, varying functions, divergent organizational structures, dynamic historical conditions, which must lead to diversity and pluralism, then reactive homogeneity, then back, and back again, yielding imperishability. One analysis using secularization theory, for example, might see the PRC as a hard-secular state to start, one that comes out of what Szonyi describes as, by referencing Partha Chatterjee, "an exemplar of ... the derivative discourse of anti-colonial nationalism." ${ }^{\prime 58}$ Its operative stance is derived from the western discourse on secularization which seeks to banish religion because its total absence would be construed as a mark of modernity and cultural superiority. Associated with this is a belief that Tan labels as "vituperative atheism", which would in part explain the horrendous brutality and violence that was unleashed during the Cultural Revolution. But the theorist might go on to say that because of the persistence in religion, the PRC is now transitioning into a soft(er) secularism that tolerates and even happily accepts charity-performing religious communities, ${ }^{59}$ particularly from the five officially recognized religions (Buddhism, Daoism, Roman Catholicism, Protestantism, and Islam). Nevertheless, the state will continue to prosecute and persecute separatist, terrorist, political Islam and try to "re-educate" benighted Muslims to the better, more rational core socialist principles.

Just as easily, another theorist could see the apparatchiks of the Communist Party of China (CPC) as priests, and the party itself as the church of a political or civil religion, with the core socialist principles as shared common "religious" values. Such an interpretation would see the five religions as coexistent but secondary to state institutions and values, as they remain potential competitors with divergent visions of what utopia might look like. This is not unlike the position that Buddhism and Daoism have occupied over much of history in relation to state Confucianism. Liang Yongiia argues that the Chinese state has never been secular" ${ }^{60}$ and that "For more than two millennia, the core ideological conviction shaping and buttressing imperial governance also direct correlatively the purpose and process to regulate, control, and exploit all rivalry (sic) religious traditions whenever it is deemed feasible and beneficial to the state." (Liang 2014). Both Cao Nanlai (Cao 2018) and Laliberté $(2012,2015)$ agree with Liang's assessment that the current PRC policies and actions follow the traditional "state lead/religion follow" model. It might be said that this supremacy of the Confucian state over other religions was likely the aspect that the Jesuits observed. Secularization theory and secularism appears, therefore, to have led us in a circle back to traditional conventions, reminding us

58 While this is true, the Chinese example is odd in that it is unlike the mainstream Hindu, Muslim, and Buddhist nationalisms as the Chinese mainland abandoned its own religious traditions and adopted instead Communism, a foreign ideology. However, one might argue, like Liang, Cai, and Laliberté, that the current policies and implementation mark a distinctive continuation of traditional norms and values.

59 See Laliberté (2015) on the Taiwanese Buddhist group, Cizi (Tzu Chi or Buddhist Compassion Relief).

60 We still encounter here the issue of definition. If we take seriously Xunzi's theory, then Confucianism, as Tan and Spickard insightfully identify, is neither simply religious nor secular-the categories are not theoretically helpful. 
of Meynard's remark that secularism originated from a Western attempt to understand China. Here, Xunzi's theory could easily be employed to explain or justify state supremacy and the use of a religious hierarchy and celebratory pageantry for the end of harmony. Most importantly, in such a system, the primary allegiance of citizens and religious groups must be to the state civil religion; and religious communities especially would be required to conform to the laws of the church of the CPC. When framed as such, the PRC could be understood as practicing Bellah's civil religion, wherein the state is sacralized though without sharing Bellah's values, and not in the way elucidated by Xunzi.

These are just two possible readings of the current PRC situation in which religion finds itself. In short, a general Chinese theory of religion would be a flexible one that embraces many specific sub-theories and anticipates transitions and transformations, without the expectation of one eternal unchanging universal theory that is ultimately indeterminate.

Funding: This research was funded by Indonesia Endowment Fund for Education (LPDP).

Conflicts of Interest: The author declares no conflict of interest.

\section{References}

Campany, Robert F. 1992. Xunzi and Durkheim as Theorists of Ritual Practice. In Discourse Theory and Practice. Edited by Frank Reynolds and David Tracy. Albany: SUNY Press, pp. 197-231.

Cao, Nanlai. 2018. Chinese Religions on the Edge: Shifting Religion-State Dynamics. China Review 18: 1-10. Available online: https://www.jstor.org/stable/10.2307/26535088 (accessed on 7 February 2019).

Eno, Robert. 2016. The Great Learning and The Doctrine of the Mean: An Online Teaching Translation. Available online: http://www.indiana.edu/ p374/Daxue-Zhongyong.pdf (accessed on 28 March 2019).

Fazang. n.d. Treatise on the Golden Lion. In The Zensite. Translated by C. C. Change. Available online: http://www.thezensite.com/ZenTeachings/Miscellaneous/Treatise_on_Golden_Lion.html (accessed on 22 March 2019).

Freedman, Maurice. 1974. On the Sociological Study of Chinese Religion. In Ahern, Emily M., Arthur P. Wolf, \& Joint Committee on Contemporary China. Subcommittee on Research on Chinese Society. Religion and Ritual in Chinese Society. Stanford: Stanford University Press.

Jeung, Russell, Brett Esaki, and Alice Liu. 2015. Redefining Religious Nones: Lessons from Chinese and Japanese American Young Adults. Religions 6: 891-911. [CrossRef]

Koller, John M. n.d. Ox-herding: Stages of Zen Practice. In ExEAS (Expanding East Asian Studies). New York: Columbia University.

Laliberté, André. 2012. Buddhist charities and china's social policy: An opportunity for alternate civility? Archives De Sciences Sociales Des Religions 57: 95-117. Available online: http://ezproxy.library.yorku.ca/login?url=https: //search-proquest-com.ezproxy.library.yorku.ca/docview/1283639690?accountid=15182 (accessed on 2 April 2019).

Laliberté, André. 2015. The politicization of religion by the CCP: A selective retrieval. Asiatische Studien-Études Asiatiques 69: 185-211. [CrossRef]

Lau, Din-cheuk, trans. 1963. Lao Tzu: Tao Te Ching. Middlesex and New York: Penguin.

Legge, James, trans. 1885. Li Yun (Ceremonial Usages; Their origin, development, and Intention). In Book of Rites. Available online: http://www.sacred-texts.com/cfu/liki/liki07.htm (accessed on 30 March 2019).

Liang, Yongjia. 2014. Hierarchical plurality: State, religion and pluralism in southwest China. In State and Secularism: Perspectives from Asia. Edited by Michael S. H. Heng and Ten Chin Liew. Hackensack: World Scientific, pp. 51-70.

Meynard, Thierry. 2005. Religion and Its Modern Fate: The Shaping of the Concept between the West and China. International Philosophical Quarterly 45: 483-97. [CrossRef]

Puett, Michael. 2013. Critical approaches to religion in China. Critical Research on Religion 1: 95-101. [CrossRef] Sommer, Deborah, ed. 1995. Chinese Religion: An Anthology of Sources. New York: Columbia University Press.

Spickard, James V. 2017. Alternative Sociologies of Religion: Through Non-Western Eyes. New York: New York University Press.

Szonyi, Michael. 2009. Secularization Theories and the Study of Chinese Religions. Social Compass 56: 312-27. [CrossRef] 
Tan, Sor Hoon. 2010. Secular Religiosity in Chinese Politics: A Confucian Perspective. In State and Secularism: Perspectives from Asia. Edited by Michael S. H. Heng and Ten Chin Liew. Hackensack: World Scientific, pp. 95-122.

Watson, Burton. 1963. Xunzi: Basic Writings. New York: Columbia University Press.

Watson, Burton. 1968. The Complete works of Chuang Tzu. New York: Columbia University Press.

Watson, Burton. 2002. The Essential Lotus. New York: Columbia University Press.

Woo, Terry Tak-ling. 2010. Chinese Popular Religion in Diaspora: A Case Study of Shrines in Toronto's Chinatowns. Studies in Religion/Sciences Religieuses 39: 151-77. [CrossRef]

Woo, Terry Tak-ling. 2016. Distinctive Beliefs and Practices: Chinese Religiosities in Saskatoon. Journal of Chinese Overseas 12: 251-84. [CrossRef]

Woo, Terry Tak-ling. 2019. Religion and Politics in the People's Republic of China: An Appraisal of Continuing Mistrust and Misunderstanding. Religions 10: 333. [CrossRef]

Zhao, Litao. 2010. Religious Revival and the Emerging Secularism in China. In State and Secularism: Perspectives from Asia. Edited by Michael S. H. Heng and Ten Chin Liew. Hackensack: World Scientific, pp. 301-17.

(C) 2019 by the author. Licensee MDPI, Basel, Switzerland. This article is an open access article distributed under the terms and conditions of the Creative Commons Attribution (CC BY) license (http://creativecommons.org/licenses/by/4.0/). 
Article

\title{
Popular Religions and Multiple Modernities: A Framework for Understanding Current Religious Transformations
}

\author{
Cristián Parker $\mathbb{D}$ \\ Institute for Advanced Studies, Universidad de Santiago de Chile, Santiago 7500618, Chile; \\ cristian.parker@usach.cl
}

Received: 1 August 2019; Accepted: 22 September 2019; Published: 1 October 2019

\begin{abstract}
Popular, ethnic, and folk religions endure in all regions of the planet, but specially in underdeveloped or developing non-Western countries. The main objective of this paper was to propose a framework for understanding this popular religious trend. Although religion in general has previously been linked to multiple modernities, the revitalization of popular religions has not. While Eisenstadt's original theory of multiple modernities has been criticized on several aspects, his interpretative approach is valid provided that the contradictory dynamics of modernizing processes are recognized. The epistemological shift suggested by this article involves recognizing the biases that Western sociology has brought to its analysis of religions. Once we treat modernities as multiple, the specificity of each modernity opens up the spectrum of religious alternatives that flourish in every geo-cultural area. The growing diversity of popular religious expressions in the Global South stems from the fact that they are supported by thousands of believers. Their lived religions spills beyond religious institutions. These popular religiosities are the main sources of religious diversities and religious resistance in the context of multiple modernities. Lived religion and symbolic action allow us a better understanding of the magical-religious expressions of peoples of the world.
\end{abstract}

Keywords: popular religions; multiple modernities; lived religion; religious diversity

\section{Introduction}

Popular, ethnic, and rural folk religions endure in all regions of the planet, but specially in underdeveloped or developing non-Western countries. In many places, they are vigorous; this is especially true of urban popular religions in areas undergoing rapid modernization.

Yet the relationship between popular religion and modernization is complex. The renaissances in the major religious traditions-Islam, Hinduism, Christianity, Buddhism, etc.-in various parts of the world have multiple connections to modernization (Hefner 1998; Offutt 2014). This calls for an explanation that goes beyond mere criticism of the classic theories of secularization (Casanova 2006).

In Christianity, we have the emergence and expansion of Pentecostalisms of various kinds (Vijgen and Haak 2018), including the vertiginous diffusion of Catholic Charismatics (Eckolt 2013). Many new Evangelical churches as well as independent cults have accentuated Christian religious diversity, especially in the Global South (Pew Research Center 2011).

African and ethnic religions are growing not only in their lands of origin; they are present now in transcultural contexts (Adogame and Spickard 2010). We observe an increasing number of popular expressions of the Asiatic great religions (Hinduism, Buddhism, Daoism, Shinto). Folk and traditional religions attract growing numbers, although, unlike other popular religions, they are declining slightly as a percentage of a growing population (Pew Research Center 2015a). Popular religious expressions are found in Islamic contexts: in North Africa, Sub-Saharan Africa, the Arab countries, and in Asiatic 
Islamic; each has singular characteristics. New transnational religious movements (Michel et al. 2017) and revitalized indigenous religions are emerging throughout the globalized world (Parker 2002).

Although they reflect only the surface of this phenomenon, the available statistical data demonstrate a decline in non-believers, and that in the near future, there will be more believers than today, in both raw numbers and proportional to the world population (Johnson and Zurlo 2015; Johnson and Grim 2018; Pew Research Center 2015c). In any case, popular religions and spiritualities are spreading in mass society through the new technologies of communication and information, and through migrations. They are bypassing the established churches and elitist forms of religions.

The main objective of this paper was to propose a new framework for understanding this popular religious trend in the context of multiple modernities. Although religion in general has previously been linked to multiple modernities (Beriain 2014; Hefner 1998; Michel et al. 2017; Offutt 2014; Smith and Vaidyanathan 2011), the revitalization of popular religions has not.

A revised theory of multiple modernities will allow us to comprehend how popular religions are being reinvigorated throughout the world, especially in peripheral modernities. In the first part of this paper, we briefly develop a conceptual and methodological approach. In the second part, we review the popular religions phenomenon in order to advance a critical analysis of the multiple modernities theory. In the light of these sections, we sketch a conceptual framework for a revised theory and draw some conclusions.

\section{Conceptual Scope and Methodology}

Our main interest is in the diverse popular religious expressions that can be found, in the most varied circumstances, in the Global South. This diversity is not a matter of the proliferation of churches, denominations, sects or movements, religious leaders, and/or new prophets. More important is the fact that these entities are supported by thousands of faithful, whose religiosity spills beyond such formal religious institutions. This popular religiosity is the main source of religious diversities in the context of current multiple modernities.

My approach adopts an unconventional perspective that outlines a non-western-centric approach to popular religions. For this reason, we must begin with some conceptual clarifications.

First, we are referring here to religious diversity and not to religious pluralism. Indeed, our focus is on the analysis of the real diversity of religious expressions and not merely on religions' institutional forms. Pluralism should not be confused with diversity, as Beckford and Richardson (2007) have stated. The normative, regulatory, and political perspective of pluralism is very different from the descriptive level of empirical and phenomenal diversity. The challenges of religious diversity in terms of pluralism in democratic construction are enormous (Levine 2009).

Second, we start from the fact that popular religions in the Global South are being reinvigorated and are not declining (Pew Research Center 2015a). Therefore, we leave aside the long-standing controversy about the theory of secularization (Bruce 2011; Casanova 2006; Martin 2005; Yamane 1997). My focus is centered in popular religions, the spiritual and religious expressions of the masses, the powerless, the simple people who in a thousand ways express their faith in superior or superhuman realities and who maintain a special bond with these realities that is reflected in their daily lives and in their local communities.

Let us remember that there are, from a theoretical point of view, basically two orientations for the understanding of popular religions. There is the neo-Durkheimian approach that analyzes popular religions' integrative role as a sacred canopy (Berger 1967) that guides, offers meaning, cohesion, and social integration. And there is the neo-Marxist approach (Maduro 1980) that analyzes religion as an ideological factor that contributes, within the framework of social conflicts, to hegemony or counterhegemony in society.

Given the religious dynamics in Latin America over the last forty years (Parker 1993, 2005, 2016), it is relevant to remember that Marx's old slogan about religion being the "opium of the people" (Löwy 2006) stands as a background to the sociological debate about popular religions. Such 
controversial affirmation contains a partial truth, not in the sense that the symbolic religious was illusory, but in the literal sense of the opium that is a relief for the suffering:

"Religious suffering is, at one and the same time, the expression of real suffering and a protest against real suffering. Religion is the sigh of the oppressed creature, the heart of a heartless world, and the soul of soulless conditions. It is the opium of the people" (Marx 1969, p. 304).

Therefore, with Gramsci (1954, 1972; Nesti 1975) we can affirm that in every expression of popular religion, there is a potential protest against oppression, a sort of a historical form of the "cry of the oppressed", a form of response to dominant society and culture.

In this respect, Byrd (2016) aesthetic-expressive component of religion is more pertinent to understanding popular religious expressions than are its cognitive-instrumental or moral-practical components. This aspect of religion articulates itself in rituals, icons, sacred music, architecture and fine art, as integrated within religious worldviews.

Finally, popular religions are a social product. They are socially constructed by people and communities. It is true that pain, suffering and anguish, love, and hope, have no geopolitical or geocultural boundaries. Yet, they have symbolic (and sometimes very real) borders because forms and semiological codes frame the answers with which cultures, religions, and spiritualities seek to channel those personal and collective feelings. Cultural and religious perceptions and mores are constantly being built into the geographic and geo-cultural landscape so that the landscape itself becomes a series of icons and mnemonics that signal religious identity and collective socio-religious meanings (Harvey 2014).

In this essay, we develop a framework to understand the role played by popular religions in the making and remaking of religions and spiritualities in the contemporary world. We say framework rather than theory because the phenomenon is complex and evolving. Our proposal is to give relevance to a bottom-up perspective: a view from the religious experience of the socially disadvantaged groups and classes and from peripheral regions and continents. This opens a different window than the one usual in the sociology of religion. It produces a set of propositions about contemporary religious evolution that should be considered hypothetical and that should be verified by in-depth examinations of popular religions in multiple sociocultural and historical circumstances.

\section{Popular Religions within Multiple Modernities}

The growing religious diversity and contemporary evolution of popular religions and spiritualities, mainly in Africa, Latin America, and Asia, reveals new cultural and religious patterns that can only be understood within the context of what has been called 'multiple modernities' (Eisenstadt 2000, 2003, 2013). However, the theory of multiple modernities has not considered popular religions nor have the abundant studies on popular religions around the world approached this phenomenon in comparative intercontinental and transnational systematic terms.

Religion is a distinctive cultural and institutional element of what Eisenstadt calls multiple modernities. But both Eisenstadt and Berger, in their analysis of religious pluralism in the framework of multiple modernities, do not address popular religions (Eisenstadt 2000, 2003; Berger 2014). These subjects of study are off their radar since their analysis focuses mostly on the social, cultural and mainstream religious phenomena, leaving aside the elite-popular dialectic, or the social classes divide, in such dynamics. Then, to understand our assessment and criticism of the concept of multiple modernities, it is necessary to take a brief comparative look at the phenomenon of worldwide popular religions to appreciate their common features and their differences precisely in the diverse contexts generated by multiple modernities.

Here are two examples of popular religion, taken from recent news. Although by no means exhaustive, they highlight the main issues raised by our subject.

On 8 December 2018, in Chile-a country where the Catholic Church is in a deep crisis of legitimacy because of pedophile clerics-more than one million faithful made a pilgrimage to the Virgin of Lo Vásquez on the route between the country's two megacities: Santiago and Valparaíso. Chile has 
only 18 million inhabitants. Many of the pilgrims were young people, replicating their grandparents' devotion to the Virgin Mary. They traveled by bicycles and not on foot, and they organized through the internet and social networks, not through churches. Their religious expression simultaneously demonstrated their religious and ecological commitment to the future.

A few weeks later, on a single day in India, an estimated 30 million Hindus attended the Kumbh Mela, a religious festival in Prayagraj, Uttar Pradesh, where the Ganges and the Yamuna rivers meet. This ritual has become the largest in the world, with as many as 120 million attending during the entire festival period (estimate for 2013). The Hindu tradition says that drops of the nectar of immortality fell into these sacred rivers from an urn, or kumbh, that was being fought over by the gods and demons. Now millions of pilgrims come every three years to pray that the holy waters will emancipate them from the cycle of rebirth (Safi 2019).

Despite the many competing definitions of the term popular religion (Long 2005), there is a common understanding that each world religion comes in both official and popular forms. These forms exist in a dialectical tension with each other, with the popular form sometimes submitting but also sometimes rejecting the official form's authority (Possamai 2015; Vrijhof and Vaardenburg 1979; Nickerson 2008). These forms are intertwined but asymmetric: official religion defines the 'correct' and orthodox way of believing and practicing and controls religious institutions, but popular religion appeals to people's actual religious needs.

Official religion cannot just abolish the popular form, because in doing so it threatens its ties to ordinary people: peasants, workers, urban dwellers, the poor, and the downtrodden. These are the underprivileged, powerless, and subaltern social classes common in all stratified societies, who build all aspects of their culture in tension with the dominant culture (Hall 1981). They do this for religion too. These ordinary people embrace religious expressions-rituals, cults, and beliefs-that express their search for a relationship with the extraordinary (the divine, the supernatural). These expressions may be individual or communitarian, and they typically seek a more direct, effective and affective way to reach the untouchable in their everyday lives. They often involve icons and the human body. They represent a less intellectual and dogmatic type of religiosity than official religion approves.

Beyond their diverse local traditions and their multi-coloured symbolisms, the popular and ethnic religions of Latin America, Africa, and Asia share some common features. These include such things as: an attachment to life, the relevance of health and healing, a perception of evil, ritualistic and semiological symbolisms, the presence of supernatural and extraordinary energies (e.g., miracles), and a more or less accentuated distance from Western thought and rationality. Most popular religions are syncretic forms of cultural and religious traditions that can be hardly recognized if we rest upon a culturally constructed Western category —'religion' — which may not be significant in other cultural and historical contexts (Parker 2010; Stewart and Shaw 1994).

In Latin America, the dominant examples are the various popular Catholicisms, which mingle Indigenous and Iberian Catholic traditions, supplemented by African influences in the Caribbean and Atlantic coasts (Bidegain and Soler 2010; Fitó 2009; Guanche 2008; San Pedro Nieto 2006). The violent or pacific encounter between counterreformation Catholicism, the multiple native religions, and the slave trade, produced various syncretic religions that combined elements of at least two and often three of these traditions (Parker 1993, 2005, 2016; Marzal 2013). The diversity of the "Latin modernity" (the Latin American way of being modern, which has its own logics) is built on this syncretic soil. We can see this in both Pentecostal preaching and in folk-religious ritualism. It is impossible to understand Latin American religiosity without understanding this colonial encounter.

On the other side of the planet, popular religions in Eastern Asia have gained growing attention from scholars in recent decades. At one end of the development spectrum, there is a revitalization of popular religions in modernizing China; on the other end, there is the patent persistence of Japanese popular religiosity despite Japan's high modernity. Though religious statistics emphasize the relative non-religiousness of that region (Pew Research Center 2015b), this view reflects the lack of official religious membership (Hackett et al. 2015). In addition, there are many traditional 
East Asian practices that present themselves as philosophies and not religions in the Western sense (Ma and Meng 2011; Yeung 2003; Parker 2018). Indeed, popular religion in China has often been studied under a Western-oriented optic, with magic having a predominant role (Weber 1951).

In modern China, the three teachings-Confucianism, Buddhism and Daoism-often interact with each other, so lived religion freely integrates them into many popular and syncretic rituals. These include devotion to the ancestors, pilgrimages, shrines, and shamans (Ma and Meng 2011; Clart 2012). Some scholars emphasize the elements of popular resistance present in such activities (Chau 2005), but that is only part of the picture, even recently. Traditional Japanese popular practices are more integrated into the experience of a great web of being, in which the land, the spirits, and human beings animated the world and the cosmos. It was not something to believe, it was just the way the cosmos was. This is why religious practices in Japan (especially Shinto) are historically not considered "religion" in the western sense (Kisala 2008). The vision of the planet as a living organism that to be cared for with affection and not exploited and plundered is close to the modern perspective on Gaia.

The Indian subcontinent's dedication to the old Dharmic wisdom that there are many paths to God (Chandrasekharendra 2008) matches its long history of religious syncretism and its tolerance for popular manifestations of religion as opposed to the imposition of an orthodoxy from above. Southeast Asia similarly demonstrates a similar openness in both the official religions-Buddhism (Theravada and Mahayana), Islam (Sunnism and Shiism), and Christianity (Protestantism and Catholicism)—and a multitude of 'local' or 'indigenous religions' and traditional belief systems (Sofjan 2016). In Buddhism, for example, this includes a wide range of popular rituals, including the veneration of the Buddha, of other buddhas, of bodhisattvas, and of saints. Popular pilgrimages increase Buddhism's ability to incorporate pre-existing local traditions (Khoon San 2002), as also true with New Year's and harvest festivals (Ghosh 2004).

African religious history is marked by colonialism, and the majority of Africans are now adherents of Christianity or Islam, religions imposed from another cultural context. African people often combine traditional practices with Abrahamic elements (Pew Research Center 2010; Quainoo 2003). African traditional religions are polytheistic and tolerant. They are generally oral rather than scriptural, include belief in a supreme creator, belief in spirits, veneration of the dead, and the use of magic and traditional medicine. Ancestors appear more important on a daily basis than the supreme deity. The role of humanity is generally seen as one of harmonising nature with the supernatural (Asante and Mazana 2009).

Large numbers of Africans actively participate in Christianity or Islam yet also believe in witchcraft, evil spirits, sacrifices to ancestors, traditional religious healers, reincarnation, and other elements of traditional African religions (Pew Research Center 2010). "The gulf that exists between the secular and the sacred in the West does not appear in traditional African religion" (Asante and Mazana 2009, p. xxvii).

The Islamic world is not limited to the Arab countries of North Africa and the Middle East, it includes relevant expressions in Asia and sub-Saharan Africa. Given that Islam is organized in a very different way from the Christian tradition; that its principles of submission to Allah applies to all dimensions of life; and that religion and politics are very intertwined (Naso 2018), it is difficult to characterize the popular Islamic religions as we do in the cases of Christianity or Buddhism. The importance of Qur'anic, Sunna, and Sharia prescriptions means that the Muslim grassroots do not have the same ritual autonomy as we find in other universal religions. On the other hand, the lack of a theological authority and an official priesthood, plus the ambiguities of the authority of the ulama (Zaman 2009), make schools, doctrines, orders, and movements within the Uma proliferate (Hassan 2007; Possamai 2009).

Popular Islam (or "folk Islam") is an umbrella term used to describe different forms of Islam that incorporate native folk beliefs and practices. Folk Islam has been described as the Islam of the urban poor, country people, and tribes, in contrast to orthodox or "High" Islam (Gellner 1992). Scholars agree that Sufism and Sufi concepts are often integrated into folk Islam. 
But Gellner's theses have been criticized, since there is no evidence of a direct oppositional association between the Sufi orders and the Enlightened Islamic reform elites (such as the Salafi) (van Bruinessen 2009). The mistake, in our opinion, depends on the point of view. Looking at the problem through the Popular religion/Official religion typology, we could say that the orders (Tariqa), sheiks and Sufi saints, and Salafist teachers and ideologues are part of an official religion; folk practices and Sufi mysticism are closer to popular sentiment. Usually these popular religious practices involve a degree of syncretism with local or non-Islamic traditions, which is why they are considered heretical by the religious agents who guard the orthodoxies of the Qur'an, the Sunna and the Hadith (Asante and Mazana 2009). The so-called "superstitions" and devotion to the saints are forbidden by official Islam (Muyahid 2012), yet they continue to be practiced.

Popular forms of Islam have contributed to the confrontation with the West. The Arab and Islamic countries perceive globalization as an attempt to implant Western dominance and as a threat to the preservation of their religious and cultural identity. Although there are different views of globalization and of modernization processes, a large percentage of Muslims see them as an imperialistic way of cultural invasion and an attempt to destroy their heritage and religion (Masud et al. 2009). Modernization of the state, the law and the economy are seen as a way to secularise the nation and thus as a way of betraying Islam. This idea nourishes the Salafi elites and the jihadist vanguards, but it must be noted that this idea is deeply rooted among simple believers (van Bruinessen 2009, p. 135).

In short, the popular religions landscape is complex. It varies from region to region, from nation to nation, from continent to continent. Some religious expressions are closer to traditional practices, others constitute highly modern and even post-modern religious styles. In Latin America, the classical folk religion (traditional, peasant, rural, illiterate, and pre-modern) is no longer predominant, although it can be found in many African and Asian countries. Yet it is indisputable that there are many vital popular religions in the heart of the megacity, in the urban core of multiple modernities (Parker 2018).

We have personally found similarities between the popular urban religious landscapes of various megacities: Beijing, Buenos Aires, Tokyo-Yokohama, Bangkok, Cairo, Lima, Sao Paulo, Rio de Janeiro (Barrera 2012), Mexico City (Suárez 2013), and Johannesburg (Wilhelm-Solomon et al. 2016). Van der Veer (2015) has assembled scholars' observations in various cities of Asia: Singapore, Mumbai, Karachi, Seoul, Hanoi, Beijing, Hong Kong, Shanghai, Jakarta, Bangkok, and Metro Manila. His conclusions are clear, although modernizing urban elites in these places are trying to promote secular nationalisms, the presence and revival "of some crucial aspects of religion keep its ultimate triumph at bay" (Van der Veer 2015, p. 14).

\section{Multiple Modernities and Its Contradictions}

Classical modernization theory argued that modernity resulted in the secularization of societies. The theory of multiple modernities allows us to criticize this theory's Eurocentric assumptions and to understand the sociohistorical, ideological and institutional contexts that have given rise to different forms of modernity in different parts of the world. These modernities have different interactions with religious systems and events, only some of which lead to religious decline. Instead, we should expect a diverse process of 'multiple secularizations' (Martin 2005; Smith and Vaidyanathan 2011). This approach argues that secularization must be understood as a complex process and not a lineal one. Globalization leaves footprints and affects its own religious evolution, so societies experiencing differing modernizing processes will have different religious paths (Oro and Steil 1997).

Therefore, secularization is better understood as a more or less radical and systemic transformation of the preceding religious field than as a gradual and inevitable decrease in the relevance and significance of the religious dimension in society. This transformation can lead, in a few cases, to an increase in non-belief or classical atheism. But on other occasions, especially in developing multiple modernities, it leads to the increase of alternative spiritualities not linked to instituted religions.

While Eisenstadt's original theory of multiple modernities has been criticized on several grounds, each of these argued for even more complexity, and thus a less uniform religious development. 
Schmidt (2006), for example, argued that Eisenstadt's original theory failed to pay sufficient attention to economics. Kamali (2012) argued that although Eisenstadt considers center-periphery dynamics, he does not delve into colonial and neocolonial conflicts. In addition, we should point out that Eisenstadt does not consider inequalities and negative global flows (Ritzer and Dean 2019), nor currently increasing social conflicts (Touraine 1995, 2006). Indeed, the uneven development of capitalism with its dialectics of north/south and center/periphery, together with the hegemonic globalization, raises the resistance of local or 'glocal' identities (Castells 1998, 2012). All these dynamics affect religious evolution and its expressions in different geo-cultural areas of the contemporary world.

Consequently, and as we look at the evidence provided by Norris and Inglehart $(2002,2011)$ about the global religious dynamics, including the global north and the global south, we can presume that each religious/civilizational area of the planet has its own specific cultural and religious dynamics.

These facts make us realize that in reality what happens is that the specific religious evolutions depend much on the regional (or continental) history, culture and religious dynamics. Depending on the type of analysis employed, one can identify at least nine great religious/civilizational or geo-cultural areas in the world today: Western Europe; Eurasia (Central Eastern-Europe and North-Center Asia); North America; Latin America and the Caribbean; Middle East-Arabia; Indo-Asia; South-East and East Asia; Sub-Saharan Africa; Oceania. The hypothesis that these geo-cultural-religious areas of the world correspond to different processes of modernizations can be sustained-mutatis mutandis-in historical, cultural and statistical terms. We can presume that in each religious/civilizatory area we will find specific religious field dynamics driven by the main world religious traditions historically spread through the region for centuries and the peculiar arrangements between religions and society in each case through the modernization processes from the eighteenth century onwards, including colonization and neo-colonization processes and the attempts toward decolonization in the nineteenth and twentieth century. (Parker 2016, p. 42)

Globalization has triggered many processes, including scientific-technological advances, revolutionized communications, and a new world geopolitics. New technologies of information and communication have in their turn shifted the way that people believe and express their faith. Some of these persons and groups wish to be religious outside the control of an organized religious institution. For them, the Internet has become the ideal medium for communicating religious beliefs and practices (Dawson and Cowan 2004; Possamai 2012). In this social context, syncretism, popular tradition, and religion à la carte are among the most common forms of religious participation.

The globalized economy produces socioeconomic inequalities (Piketty 2014) and new geopolitics. Violence remains in many peripherical societies and even in the emerging economies that have experienced rapid growth, such as Brazil, South Africa, India, China. There is also the post-Cold War multiplication of conflicts and local wars at the subnational or regional level in different parts of the world, especially in the Middle East and Africa, but also in Asia and Latin America (Cohen-Tanugi 2008). Increased waves of migrations, democratic instability, pollution, and climate change all affect the social and existential conditions of everyday life. These nurture new spiritual and faith searches. New social movements have gained the scene: feminist, sexual diversity, environmentalists, etc. Institutional crises in many churches—not just Roman Catholicism-also fuel religious change. New popular religious themes emerge: healing, gender, body and corporeality, subjectivation, materiality and spirituality, migrations, territoriality, deinstitutionalization, interculturality, cyberspace.

Berger (2014) was one of the most enthusiastic theorists in the effort to connect the revitalization of religion with multiple modernities. Reversing his previous theoretical framework (Berger 1967), which saw the 'sacred canopy' as a force for social integration and its decline as a source of secularization, Berger came to recognize the existence of multiple modernities and even of the difference between central and peripheral modernities. Yet faced with the alternatives of fundamentalism or relativism, he emphasized individual freedom in the choice of faith. This liberal approach exalted the 
religious pluralism of the US, which he regarded as more successful than other societies. In contrast, Spickard (2017a) has shown how the religious pluralism in the USA is problematic in the face of increasing economic inequality, a socioeconomic split between the elites and the population, and shifts in the nature of the religious field.

Still, Eisenstadt's and Berger's different approaches to multiple modernities and their consequences for religion open a fruitful path to interpret what happens with popular religions in today's world. If we add to this a greater appreciation of these modernities' structural contradictions than either author provides, we can understand even more deeply the relationship between societies and their religions. In many cases, for example, popular religions can be seen as a counterculture to the modernization processes, but at the same time as a dialectical product of them. In such cases, they are part of the specific transformations and contradictory modernizations taking place in society.

\section{Globalization Leaves Footprints and Affects Its Own Religious Evolution, so Societies Experiencing Differing Modernizing Processes Will Have Different Religious Paths}

The reflexive turn proposed here aims to counter-balance those classical sociological theory of religious phenomenon that lack a comprehensive perspective. This involves recognizing the biases that Western sociology has brought to its analysis of religions and correcting them by the addition of non-Western approaches. Several authors are already moving in this same direction (McGuire 2008; Possamai 2009; De la Torre 2013; Mallimaci 2017; Spickard 2017b).

Religious diversity is not recent; it has existed for thousands of years, but it has not always been visible. Globalization and the concept of multiple modernities make it possible to see old and new forms of diversity. Therefore, we are not just observing the growth of the empirical and historical diversification of religious alternatives. Instead, we are initiating a new social perception, an epistemological shift in what we understand by diversity and pluralism and their role in contemporary religious transformations.

Each civilization has its own history, which shapes its way of seeing. No single civilization can give us an adequate conceptual framework for understanding the diverse socio-historical-religious experiences of all others. The classic theory of secularization that arose in Europe is as exceptional as that continent's religious history and culture (Davie 2006). It cannot be simply applied to understand what happens in Latin America, Asia, the Middle East, Arab countries, Sub-Saharan Africa, or other regions.

From this point of view, even the diverse expressions of cults, beliefs, mysticisms and spiritualities within Christian backgrounds around the world cannot simply be reduced to manifestations of 'generic' Christianity-especially as seen from a Euro-Christian-centric epistemology or theology.

Once we treat modernities as multiple, the specificity of each modernity opens up the spectrum of religious alternatives that flourish in every geo-cultural area, including non-religious alternatives. This allows us to explain, for example, that European diversity historically includes, since the emergence of the Modern State, an important segment of non-practicing believers, non-believers, and atheists. This secularizing trend has been diverted in recent decades by the migratory flows that have affected the much greater presence of Muslim believers and to a lesser extent, Asians believers on the continent.

The diverse magico-religious expressions of peoples of the world are complex phenomenon and must not be reduced to secondary forms of religions. They are social constructions that are not built, centrally, on rationalized ways of living, as the case of institutionalized Western Christianity. The rationale of social action that supports popular rituals follows another logic (Parker 1996), different from the rationalistic dominant logic of the Western pattern of modernity. That popular logic is not pre-modern. It is able to interact with modernity and not reject it, though it can sometimes resist certain oppressive or destructive forces coming from outside.

The challenge for critical social theory is to develop a way of observing popular religions that does not simply treat them as deviant forms of European religious life. Such 'orientalism' - as Said (1978) brilliantly exposed-is a colonialist myth. It constitutes a disdainful attitude towards other cultures and generates misunderstanding. 
Developing a new comprehensive sociological approach means making a great epistemological effort to overcome the hegemony of an analytical focus that privileges Western-oriented rational action. Understanding religious and spiritual diversity in the context of multiple modernities challenges us to develop a post-rational sociology (Costa 2014). The conceptual procedure has to come from a methodology that highlights empathetic perception and understanding. Only then can we ensure that scholarly interpretations are meaningful for the informants and do not impose an external predefined model of religion upon them (Kapaló 2013).

I propose the relevance of two sociological conceptual tools that can be applied to popular religions in the Global South. For space reasons, I can only sketch this perspective here. These two key concepts are lived religion and symbolic action.

\section{(a) Lived religion and agency}

There are new forms of studying religious behavior that goes beyond the classical Western concepts associated with the word religion. An epistemological shift has been taking place since the beginning of this century. Many scholars have been focusing on actually lived religion and the religious experiences of people in their everyday lives (Ammerman 2016). Drawing on extensive, mostly qualitative fieldwork, this research has shown that the many ways in which people express themselves spiritually rarely fit neatly into the conceptual categories that have animated the classical sociological approaches to religion (McGuire 2008). Ammerman, McGuire, and others have argued that the classical concepts fail to see many parts of the religious landscape. If, instead, we look at the ways ordinary people produce and reproduce their symbolic world, we will observe that religion is in very good health-even in supposedly secular contexts.

Most of these scholarly interventions focus on the lived religions of the Global North. They thus focus on religious individualism - or at least on individual manifestations of religions that occur in local congregational contexts (Ammerman 2016). This is not the pattern that lived religion takes in Asia, Latin America and Africa. There, the religions that people produce in my own way or á la carte are generated by agents whose cultural and spiritual background is communitarian rather than individualistic. The family devotions, and even personal ones, of the Chinese people, Hindus, Africans, the Muslim people, or Latin American peoples, are generated by cultural patterns that emphasize parental and community relationships: ancestors, lineages, relatives, neighborhoods, and/local communities. These patterns are reproduced as new generations re-invent old traditions (Hobsbawm and Ranger 1983). These new generations often are already immersed in modern and mercantile economies, and their embedded utilitarian and instrumental logics. Yet these logics coexist with older symbolic logics that shape both people's meanings and their ability to cope with daily life and its constraints. Anguish and problems on the one hand, and claims of meaning and identity on the other, produce lives where mere instrumental reason no longer appear as effective.

\section{(b) Symbolic action and its rationality}

In his definition of religion as a cultural system, Clifford Geertz shows that the characteristic of religion and what makes it different from other spheres is not beliefs but religious action (Geertz 1973, p. 112). This action can be practical-it can have technical or political functions-but it can also be symbolic. The latter confers meaning, delivers identity, and stimulates our fabulative, magical, mystical, and contemplative imagination. Though every religious action has a technical or socio-political side, its symbolic side is free from such instrumentality: it simply makes sense. Under many religious expressions-mainly ethnic and/or popular - the symbolic is linked to energy and not to social or political power. Certainly, the symbolic side of religious action grants a cosmic and supernatural rather than a socio-political meaning.

Eurocentric sociology encounters a problem, here, in its distinction between "religion" and "magic". Too often, sociologists use this distinction to separate the symbolic from the practical, 
assigning the first to an elite intelligentsia and the second to the non-elite poor. The latter's religion is treated as being infused with superstitious or "magical" thinking. As Mauss (1985) recognizes, the term "magic" has the connotation of a second-order religious action, a deformed ritual action. On the contrary, all religious action has both elements. There is typically a continuum between the "magical" and the "religious dimensions". Weber (1971) himself made this clear in his study of the communal dimensions of religious phenomena: that even in the most official ritual actions of churches there are magical features.

The evolutionary distinctions between magic, religion, and science in Western thought is typical of elites in all ages, whether theologians, philosophers, or scientists. As Tambiah (1991) suggests, a reaction, as a popular counterculture to the Enlightenment, was precisely paganism and folk magic.

Therefore, we suggest moving away from a concept of magic that is loaded with Eurocentric connotations and that only conceives of what is rightly religious according to the rationalizing and intellectualist Judeo-Christianity tradition or its secularized offspring. On the contrary, we find a conception of the magic-religious rite-a continuum - to be more appropriate for understanding the varied expressions of popular religions in non-Western settings. These religions are not elite and do not necessarily favor a Western-style rationality.

\section{Popular Religions and Multiple Modernities: Prospects}

The religious diversity of Latin America, Asia, Africa, and the Middle East, is part of a process leading towards a specific type of modernity in each case. Each modernity establishes patterns that generate incentives for religious growth or impose limits on the foreseeable increase in religious alternatives. The theory of multiple modernities implies that the modernization processes is not a process of lineal evolution and that even secularization follows different paths. Vigorous popular religions in different parts of the world configure, alongside other factors, different modernizing paths.

In some places popular religion takes the form of the syncretic New Age practices that are more popular than traditional churches, even competing with the neo-Pentecostal and Evangelical options that elsewhere dominate the popular sphere (Possamai 2012). In other places, more traditional popular cults attract millions, especially within the emerging economies of most urban and modern Global South countries. The invigorating of the many and sundry popular expressions of different faiths are part of the multiple modernization processes and not exotic expressions of a backward religiosity.

According to available data (Johnson and Zurlo 2015), Christianity has expanded rapidly in sub-Saharan Africa, though its prospects are much less promising in the Sino-Japanese area. The Muslim dominance of the Middle East and of North of Africa leaves room for the multiplication of schools and traditions within the Umma, but not much space for Christian or Dharmic alternatives (Hinduism, Jainism, Sikhism, and Buddhism). On the Indian subcontinent, Dharmic religions endure, Islam is probably increasing, but Christian prospects are dim. In Latin America, most popular religions are Christian-based, while Islam, Judaism, and Hinduism are not likely to see growth in the next fifty years.

The popular reconstruction of religions, magic, and spirituality in current Latin American, Asian, African, and Middle East societies no longer necessarily passes through churches, ulemas, monks, priests, and official religious institutions, although it still needs them as positive or negative references. Notwithstanding, the old official religions seek to survive by reaffirming their communal and institutional projects, especially in the Christian and Islamic areas. Sometimes, they affirm their orthodoxies and become fundamentalists; other times, their missionary or reformist vocation is highlighted.

But certainly, lived religions (Ammerman 2016; McGuire 2008) and the multiple expressions of popular religions that we have analyzed, no longer need the irreplaceable mediation of those official institutions (ecclesiastical or not). Still, there are latent short circuits in the attraction/rejection dynamic between the official institutions and their faithful. 
In this context, tradition and change evolves in constant tension. The transformation of symbolic codes, in the midst of the accelerated flow of information (Ritzer and Dean 2019), which is powered by new information and communication technologies, generates spaces and forms of socialization never before known. It re-signifies the lives of subjects, but also adds uncertainty to their existence. Different forms of faith and spirituality are swirled into this dynamic milieu.

A new sociology of religion is emerging within the framework of a post-rationalist paradigm (Costa 2014). It seeks to better comprehend popular religions' symbolic and semiological codes rather than merely analyzing the cognitive and linguistic codes of popular religious expressions. Our insistence on advancing in a non-western-centric approach to popular religions worldwide has nothing to do with an anti-Western vision but with the need to contextualize our theoretical frameworks and overcome that false identification between Western theorization and universal theorization.

A more detailed and documented analysis that follows the directions outlined in this article could open unexpected new vistas towards understanding popular religious phenomena that demands much more research that they have received heretofore. We need these new approaches to comprehend the religious and cultural transformations that await us in this century.

Funding: This research received the support of the DICYT Grant N ${ }^{\circ}$ 031694PG_POSTDOC, from the University of Santiago, Chile.

Acknowledgments: I wish to thank Cristián Rozas for his technical support and Jim Spickard for his editorial assistance provided on this paper.

Conflicts of Interest: The author declares no conflict of interest

\section{References}

Adogame, Afe, and James Spickard, eds. 2010. Religion Crossing Boundaries: Transnational Religious and Social Dynamics in Africa and the New African Diaspora. Leiden: Brill.

Ammerman, Nancy T. 2016. Lived Religion as an Emerging Field: An Assessment of Its Contours and Frontiers. Nordic Journal of Religion and Society 1: 83-99. [CrossRef]

Asante, Molefi Kete, and Ama Mazana, eds. 2009. Encyclopedia of African Religion. London: SAGE.

Barrera, Paulo. 2012. Evangélicos e Periferia Urbana Em Sao Paulo e Rio de Janeiro: Estudos de Sociologia e Antropologias Urbana. Curitiba: CRV.

Beckford, James A., and James T. Richardson. 2007. Religion and Regulation. In The SAGE Handbook of the Sociology of Religion. London: SAGE. [CrossRef]

Berger, Peter L. 1967. The Sacred Canopy: Elements of Sociological Theory of Religion. Garden City: Doubleday.

Berger, Peter L. 2014. The Many Altars of Modernity. Boston and Berlin: De Gruyter.

Beriain, J. 2014. Imaginarios Postaxiales y Resacralizaciones Modernas. Revista Latina de Sociología RELASO 4: 39-60. [CrossRef]

Bidegain, Ana María, and Juan Sánchez Soler. 2010. Religion in Latin America. Hemisphere 19: 1-46.

Bruce, Steve. 2011. Secularization. In Defence of an Unfashionable Theory. Oxford: Oxford University Press.

Byrd, Dustin J. 2016. Islam in a Post-Secular Society Religion, Secularity and the Antagonism of Recalcitrant Faith. Boston: Brill.

Casanova, José. 2006. Rethinking Secularization. A Global Comparative Perspective. The Hedgehog Review 8: 7-22.

Castells, Manuel. 1998. La Era de La Información: Economía, Sociedad, Cultura. Vol. II: El Poder de La Identidad. México D.F.: Editorial Siglo XXI.

Castells, Manuel. 2012. Redes de Indignación y Esperanza. Los Movimientos Sociales En La Era de Internet. Madrid: Alianza Editorial, ISBN 978-84-206-0960-7.

Chandrasekharendra, Saraswati. 2008. Introduction to Hindu Dharma: Illustrated. Bloomington: World Wisdom Inc.

Chau, Adam Yuet. 2005. Miraculous Response: Doing Popular Religion in Contemporary China. Standford: Stanford University Press.

Clart, Philip. 2012. Chinese Popular Religion. In The Wiley-Blackwell Companion to Chinese Religions. Edited by Randall Nadeau. Oxford: Wiley-Blackwell, pp. 219-37. 
Cohen-Tanugi, Laurent. 2008. The Shape of the World to Come. Charting the Geopolitics of a New Century. New York: Columbia University Press.

Costa, Cecilia. 2014. Post-Rational Society, Roma. Rome: Armando Editore.

Davie, Grace. 2006. Is Europe an Exceptional Case? International Review of Mission 95: 247-58. [CrossRef]

Dawson, Lorne L., and Douglas E. Cowan. 2004. Religion Online: Finding Faith on the Internet. New York: Routledge.

De la Torre, Renee. 2013. La Religiosidad Popular. Encrucijada de las Nuevas Formas de la Religiosidad Contemporánea y la Tradición (el caso de México). Pontourbe 12. Available online: http://pontourbe.revues. org/581 (accessed on 28 July 2019). [CrossRef]

Eckolt, Margit. 2013. El Fenómeno de Los Nuevos Movimientos Religiosos: Una Lectura Desde Latinoamérica. Revista Medellín CELAM XXXIX: 195-214.

Eisenstadt, Shmuel N. 2000. Multiple Modernities. Daedalus 129: 1-29.

Eisenstadt, Shmuel N. 2003. Comparative Civilizations and Multiple Modernities. Leiden: Brill.

Eisenstadt, Shmuel N. 2013. Latin America and the Problem of Multiple Modernities. Revista Mexicana de Ciencias Políticas y Sociales, Nueva Época 58: 153-64. [CrossRef]

Fitó, Montserrat. 2009. Las Religiones y Culturas de Origen Africano (Brasil, Cuba, Venezuela) a Prueba de Políticas Turísticas y Rivalidades ¿Un Desarrollo Sostenible? Études Caribéennes 13-14: 1-27. [CrossRef]

Geertz, Clifford. 1973. The Interpretation of Cultures. Princeton: Basic Books.

Gellner, Ernest. 1992. Postmodernism, Reason and Religion. Londres: Routledge.

Ghosh, Sujata. 2004. Buddhism. In The Encyclopedia of Religious Rites, Rituals, and Festivals. Edited by Frank A. Salomone. New York: Routledge, pp. 61-65.

Gramsci, Antonio. 1954. Letteratura e Víta Nazionale. Einaudi: Turín.

Gramsci, Antonio. 1972. Introducción a La Filosofía de La Praxis. Barcelona: Editorial Península.

Guanche, Jesús. 2008. Las Religiones Afroamericanas En América Latina y El Caribe Ante Los Desafíos de Internet. In América Latina y El Caribe. Territorios Religiosos y Desafíos Para El Diálogo. Edited by Aurelio Alonso. Buenos Aires: CLACSO, pp. 277-92.

Hackett, Conrad, Marcin Stonawski, Michaela Potančoková, Brian J. Grim, and Vegard Skirbekk. 2015. The Future Size of Religiously Affiliated and Unaffiliated Populations. Demographic Research 32: 829-42. [CrossRef]

Hall, Stuart. 1981. Notes on Deconstructing "the Popular". In People's History and Socialist Theory. Edited by Raphael Samuel. London: Routledge \& Kegan Paul Ltd., pp. 227-41.

Harvey, David. 2014. Seventeen Contradictions and the End of Capitalism. Oxford: Oxford University Press.

Hassan, Riaz. 2007. On Being Religious: Patterns of Religious Commitment in Muslim Societies. The Muslim World 97: 437-78. [CrossRef]

Hefner, Robert W. 1998. Multiple Modernities: Christianity, Islam, and Hinduism in a Globalizing Age. Annual Review of Anthropology 27: 83-104. [CrossRef]

Hobsbawm, Eric, and Terence Ranger, eds. 1983. The Invention of Tradition. Cambridge: Cambridge University Press. Johnson, Todd M., and Brian J. Grim, eds. 2018. World Religion Database. Leiden and Boston: Brill.

Johnson, Todd M., and Gina A. Zurlo. 2015. Trends in International Religious Demography, Center for the Study of Global Christianity. Hamilton: Gordon-Conwell Theological Seminary.

Kamali, Masoud. 2012. Multiple Modernities and Mass Communications in Muslim Countries. Global Media and Communication 8: 243-68. [CrossRef]

Kapaló, James. 2013. Folk Religion in Discourse and Practice. Journal of Ethnology and Folkoristics 7: 3-18.

Khoon San, Chan. 2002. Buddhist Pilgrimage. Kuala Lumpur: Subang Jaya Buddhist Association.

Kisala, Roberto. 2008. Japanese Religions. In Nanzan Guide to Japanese Religions. Edited by Paul Loren Swanson and Clark Chilson. Honolulu: University of Hawai Press, pp. 3-13.

Levine, Daniel. 2009. Pluralism as Challenge and Opportunity. In Religious Pluralism, Democracy and the Catholic Church in Latin America. Edited by Frances Hagopian. Notre Dame: University of Notre Dame Press, pp. 405-28.

Long, Charles H. 2005. Popular Religion. In Encyclopedia of Religion, 2nd ed. Edited by Lindsay Jones. Farmington Hills: Macmillan, vol. 11, pp. 7324-33.

Löwy, Michael. 2006. Marxismo y Religión: ¿opio Del Pueblo? In La Teoría Marxista Hoy: Problemas y Perspectivas. Edited by Atilio A. Boron, Javier Amadeo and Sabrina González. Buenos Aires: CLACSO, pp. 281-96. 
Ma, Xisha, and Huiying Meng, eds. 2011. Popular Religion and Shamanism, Religious Studies in Contemporary China Collection. Leiden and Boston: Brill.

Maduro, Otto. 1980. Religión y Conflicto Social En América Latina. México D.F.: Centro de Estudos Ecuménicos.

Mallimaci, Fortunato. 2017. Modernidades Religiosas Latinoamericanas. Un Renovado Debate Epistemológico y Conceptual. Caravelle 108: 15-33. [CrossRef]

Martin, David. 2005. On Secularization: Towards a Revised General Theory. Aldershot: Ashgate.

Marx, Karl. 1969. Towards the Critique of Hegel's Philosophy of Right. In Marx and Engels: Basic Writings on Politics and Philosophy. Edited by Lewis S. Feuer. London: Fontana.

Marzal, Manuel. 2013. Sincretismos Religiosos Latinoamericanos. In Religión. Edited by José Gómez Caffarena. Madrid: Ed. Trotta, pp. 55-68.

Masud, Muhammad Khalid, Armando Salvatore, and Martin van Bruinessen, eds. 2009. Islam and Modernity, Key Issues and Debates. Edinburgh: Edinburgh University Press.

Mauss, Marcel. 1985. Sociologie et Anthropologie. Paris: Quadrige/PUF.

McGuire, Meredith. 2008. Lived Religion, Faith and Practice in Everyday Life. Oxford: Oxford University Press.

Michel, Patrick, Adam M. Possamai, and Bryan S. Turner. 2017. Religions, Nations, and Transnationalism in Multiple Modernities. New York: Palgrave Macmillan.

Muyahid, Abdul Malik, ed. 2012. 110 Hadices Qudsis, Español_Spanish-يإسبإTrad. M. Isa García. Riyadh: Islam House, Dar us Salam Publications.

Naso, Paolo. 2018. Imam d'Italia: Una Ricerca Sulle Guide Spirituali Musulmane, Conference, 21 December. In SAFSOR, Scuola Di Alta Formazione in Sociologia Della Religione. Rome: ICSOR.

Nesti, Arnaldo. 1975. Gramsci et La Religion Populaire. Social Compass 22: 343-54. [CrossRef]

Nickerson, Peter. 2008. Taoism and Popular Religion. In The Encyclopedia of Taoism. Edited by Fabrizio Pregadio. New York: Routledge, pp. 145-50.

Norris, Pippa, and Ronald Inglehart. 2002. Islam \& the West: Testing the Clash of Civilizations Thesis. SSRN Electronic Journal. Available online: https://ssrn.com/abstract=316506 or http://dx.doi.org/10.2139/ssrn.316506 (accessed on 23 September 2019). [CrossRef]

Norris, Pippa, and Ronald Inglehart. 2011. Sacred and Secular. Religion and Politics Worldwide, 2nd ed. New York: Cambridge University Press.

Offutt, Stephen. 2014. Multiple Modernities: The Role of World Religions in an Emerging Paradigm. Journal of Contemporary Religion 29: 393-409. [CrossRef]

Oro, Ari Pedro, and Carlos Alberto Steil, eds. 1997. Globalização e Religião. Petrópolis: Vozes.

Parker, Cristián. 1993. Otra Lógica En América Latina, Religión Popular y Modernización Capitalista. Santiago: Fondo de Cultura Económica.

Parker, Cristián. 1996. Popular Religion and Modernization in Latin America, A Different Logia. Maryknoll: Orbis Books.

Parker, Cristián. 2002. Religion and the Awakening of Indigenous People in Latin America. Social Compass 49: 67-81. [CrossRef]

Parker, Cristián. 2005. ¿América Latina Ya No Es Católica? Pluralismo Cultural y Religioso Creciente. América Latina Hoy 41: 35-56.

Parker, Cristián. 2010. Syncretism. In The Cambridge. Dictionary of Christianity. Edited by Daniel Patte. Cambridge: Cambridge University Press, pp. 1202-3.

Parker, Cristián. 2016. Religious Pluralism and New Political Identities in Latin America. Latin American Perspectives 43: 15-30. [CrossRef]

Parker, Cristián. 2018. Popular Religions and Multiple Modernities: A Non-Western Perspective. In Culture and Identity. Edited by Wilfred April. London: InTech, pp. 91-112. [CrossRef]

Pew Research Center. 2010. Pew Forum on Religion \& Public Life: Tolerance and Tension: Islam and Christianity in Sub-Saharan Africa. Washington, DC: Pew Research Center.

Pew Research Center. 2011. Global Christianity-A Report on the Size and Distribution of the World's Christian Population. Washington, DC: Pew Research Center. Available online: https:/www.pewforum.org/2011/12/19/ global-christianity-exec/ (accessed on 23 September 2019).

Pew Research Center. 2015a. Adherents of Folk Religions. Washington, DC: Pew Research Center. Available online: https://www.pewforum.org/2015/04/02/adherents-of-folk-religions/ (accessed on 2 April 2015). 
Pew Research Center. 2015b. Religiously Unaffiliated. The Future of World Religions: Population Growth Projections, 2010-2050. Available online: https://www.pewforum.org/2015/04/02/religiously-unaffiliated/ (accessed on 2 April 2015).

Pew Research Center. 2015c. The Future of World Religions: Population Growth Projections, 2010-2050; Washington, DC: Pew Research Center. Available online: https://www.pewforum.org/2015/04/02/religious-projections2010-2050/ (accessed on 2 May 2015).

Piketty, Thomas. 2014. Capital in the Twenty-First Century. Cambridge: The Belknap Press of Harvard University Press.

Possamai, Adam M. 2009. The Multiple Modernities of Islam? In Sociology of Religion for Generartions X and Y. Edited by Adam M. Possamai. Londres: Equinox, pp. 153-66.

Possamai, Adam M., ed. 2012. Handbook of Hyper-Real Religions. Leiden and Boston: Brill.

Possamai, Adam M. 2015. Popular and Lived Religions. Current Sociology 63: 781-99. [CrossRef]

Quainoo, Samuel Ebow. 2003. Transitions and Consolidation of Democracy in Africa. Binghamton: Global Academic Publishing.

Ritzer, George, and Paul Dean. 2019. Globalization: A Basic Text, 2nd ed. Oxford: John Wiley \& Sons Ltd.

Safi, Michael. 2019. Why Kumbh Mela in Prayagraj Is Festival to End All Festivals. The Guardian. January 15. Available online: https://www.theguardian.com/world/2019/jan/15/why-kumbh-mela-in-prayahraj-isfestival-to-end-all-festivals (accessed on 23 September 2019).

Said, Edward W. 1978. Orientalism. New York: Pantheon Books.

San Pedro Nieto, Francisco. 2006. Religiones Americanas y Afroamericanas. Veritas 1: 11-42.

Schmidt, Volker H. 2006. Multiple Modernities or Varieties of Modernity? Current Sociology 54: 77-97. [CrossRef]

Smith, Christian, and Brandon Vaidyanathan. 2011. Multiple Modernities and Religion. In The Oxford Handbook of Religious Diversity. Edited by Chad Meister. New York: Oxford University Press, pp. 250-65.

Sofjan, Dicky. 2016. Religious Diversity and Politico-Religious Intolerance in Indonesia and Malaysia. The Review of Faith E International Affairs 14: 53-64. [CrossRef]

Spickard, James. 2017a. Diversity vs. Pluralism: Reflections on the Current Situation in the United States. Religions 8: 169. [CrossRef]

Spickard, James. 2017b. Alternative Sociologies of Religion: Through Non-Western Eyes. New York: New York University Press.

Stewart, Charles, and Rosalind Shaw, eds. 1994. Syncretism/Anti-Syncretism. The Politics of Religious Synthesis. London: Routledge.

Suárez, Hugo José. 2013. Fe y Generación. Análisis de Una Encuesta Sobre Prácticas y Creencias Religiosas. Alteridades 23: 49-62.

Tambiah, Stanley J. 1991. Magic, Science, Religion, and the Scope of Rationality. Cambridge: Cambridge University Press.

Touraine, Alain. 1995. Producción de La Sociedad. México D.F.: UNAM-IFAL.

Touraine, Alain. 2006. Los Movimientos Sociales. Revista Colombiana de Sociología 27: 255-78. [CrossRef]

van Bruinessen, Martin. 2009. Sufism, 'Popular' Islam and the Encounter with Modernity. In Islam and Modernity, Key Issues and Debates. Edited by Muhammad Khalid Masud, Armando Salvatore and Martin van Bruinessen. Edinburgh: Edinburgh University Press, pp. 125-57.

Van der Veer, Peter, ed. 2015. Handbook of Religion and the Asian City. Oakland: University of California Press.

Vijgen, Richard, and Bregtje van der Haak. 2018. Atlas of Pentecostalism. Atlas of Pentecostalism. July 29. Available online: http://www.atlasofpentecostalism.net/book/ (accessed on 23 September 2019).

Vrijhof, Peter H., and Jean J. Vaardenburg. 1979. Official and Popular Religion: Analysis of a Theme for Religious Studies. La Haya: Mouton Publishers.

Weber, Max. 1951. The Religion of China, Confucianism and Taoism (Original 1915). Glencoe: The Free Press.

Weber, Max. 1971. Économie et Société. Paris: Plon.

Wilhelm-Solomon, Matthew, Lorena Núñez, Peter Kankonde Bukasa, and Bettina Malcomess, eds. 2016. Routes and Rites to the City Mobility, Diversity and Religious Space in Johannesburg. London: Palgrave, Macmillan.

Yamane, David. 1997. Secularization on Trial: In Defense of a Neosecularization Paradigm. Journal for the Scientific Study of Religion 36: 109-22. [CrossRef] 
Yeung, Hing Kau. 2003. Chinese Religions and Science. Encyclopedia of Science and Religion. Available online: www.encyclopedia.com/doc/1G2-3404200078.html (accessed on 23 September 2019).

Zaman, Muhammad Qasim. 2009. The Ulama and Contestations on Religious Authority. In Islam and Modernity, Key Issues and Debates. Edited by Muhammad Khalid Masud, Armando Salvatore and Martin van Bruinessen. Edinburgh: Edinburgh University Press, pp. 206-36.

(c) (i) BY

(C) 2019 by the author. Licensee MDPI, Basel, Switzerland. This article is an open access article distributed under the terms and conditions of the Creative Commons Attribution (CC BY) license (http://creativecommons.org/licenses/by/4.0/). 

Article

\title{
Scrambling for the Centre: Ghana's New Churches as an Alternative Ideology and Power
}

\author{
Michael Perry Kweku Okyerefo ${ }^{1,2}$ \\ 1 Department of Sociology, University of Ghana, Legon P. O. Box LG 65, Ghana; mokyerefo@ug.edu.gh \\ 2 Critical Studies in Higher Education Transformation (CriSHET), Nelson Mandela University, 14 Bird Street, \\ Port Elizabeth 6001, South Africa
}

Received: 30 September 2019; Accepted: 9 December 2019; Published: 12 December 2019

\begin{abstract}
The effort expended by religious groups in Ghana to access and influence political power is not a historic novelty. Most clearly manifested in organizational strategies and the pronouncements of religious leaders, sectional ambitions in respect of political access and influence have recently gained ascendancy in response to the relatively rapid and large-scale growth of religious diversity across the nation and within its growing conurbations. This scramble for access and influence has also been fueled by the overt participation of some political leaders in religious activities, which are perceived to grant certain groups an enviable presence in the public sphere and favoured access to the corridors of state power. Focusing on two of Ghana's New Churches, both Pentecostal-charismatic organizations, as case studies, this paper explores the strategies and motivations of religious groups striving to access and influence political society in an increasingly diverse socio-cultural context.
\end{abstract}

Keywords: Ghana's New Churches; ideology; dominant ideology; alternative ideology; political power

\section{Introduction}

In spite of notions of church-state separation, religion and politics have had and continue to have a perennial relationship globally. Examples of this include the Catholic Church, which has long had and still wields supranational political influence, and forms of political Islam that have been attracting followers globally. In the democratic United Kingdom, the Anglican Church still constitutes a national church with the monarch as Head, and other individuals such as the late Billy Graham and Oral Roberts have had considerable political influence in the United States. Dovlo (2005, p. 629) has pointed out that in Ghana, specifically, as in British West Africa in general, religious influence was not expunged from the traditional public sphere by British colonial rule, since the British principle of "indirect rule" involved traditional rulers in the colonial power structure. "Colonial rule established the modern state and with it a new relationship between the state and religion", such that although "Ghana was conceived as a secular state, Christianity was identified with colonial rule because it was the religion of the Colonizers". Consequently, "English common law, with its Judeo-Christian foundations, buttressed many new laws that guided the State during that period", just as "Islamic law also influenced the development of law, especially family law".

Consequently, the Ghana Catholic Bishops' Conference (GCBC), the Christian Council of Ghana (CCG), and the Ghana Pentecostal and Charismatic Council (GPCC) all exert enormous political and moral influence on the Ghanaian polity. More recently, some of the new Pentecostal-charismatic churches and their leaders in Ghana, notably Pastor Mensa Otabil of the International Central Gospel Church (ICGC) and Archbishop Duncan-Williams of the Christian Action Faith Ministries International (Action Chapel), have also been increasingly influential politically.

In addition, there is a long history in Africa regarding the link between the spiritual and the material (Hastings 1994, pp. 275-78), which shapes religious leaders' influence in the public sphere. 
The channels thorough which such influence has been exerted in Ghana include the social institutions that religious groups establish, such as schools and hospitals, as well as the pronouncements of religious leaders on national issues. In recent times, the state has involved religious leaders in the National Peace Council, for example, which is critical in fostering peace within a hotly contested political terrain, especially during democratic elections, while religious bodies have taken it upon themselves to observe elections, for instance, to ensure their credibility and foster peace in the country.

While both Muslim leaders and those of the historic mission churches have been at the vanguard of this development, the religious landscape is changing, featuring the newcomers- the Pentecostal-charismatic churches-prominently, obviously as a result of the sheer growth in their membership and institutionalization (Okyerefo 2011). Pentecostal-charismatic leaders, such as Archbishop Duncan-Williams and Pastor Mensa Otabil, have thus been emboldened and feel they have a responsibility and a mandate to contribute to shaping public discourse and the political and economic processes. Adding to their growth is their wealth and blatant opulence, as well as the increasing popularity of these churches, which count some prominent citizens, including politicians, among their membership. All these developments point to the relationship between religion and politics in Ghana at this momentous epoch, within which broad framework the activities of the Pentecostal-charismatic churches should be understood and within which both Pastor Mensa Otabil's and Archbishop Duncan-Williams' nibbling at the centre of power will be examined.

Archbishop Duncan-Williams founded Action Chapel in 1979, while Pastor Mensa Otabil founded the ICGC in 1984. They both constitute the oldest Pentecostal-charismatic churches in Ghana, each with a sizable following in Ghana and with branches elsewhere in Africa and overseas (Okyerefo 2008, 2011, 2014). Without conflating the Pentecostal and charismatic traditions, with the former placing emphasis on the Pentecost experience and the latter on individuals' possession of the gifts of the spirit (charismata), it is observable that the boundaries of such a strict delineation are blurred in many of Ghana's new churches, hence the description "Pentecostal-charismatic". Huaco (1971, p. 249) has observed that "Marx's analysis of religion as a pseudo-control of the environment is an account of ideology as a compensatory symbolic response to stress". Social class struggle is certainly stressful to many in Ghana, and the "compensatory ideology" (Huaco 1971, p. 249) provided by Pentecostalism has assisted Ghanaians as they seek ways to navigate it. Arguably, the status of these two pioneering Pentecostal-charismatic churches have enabled their members to traverse the social class configuration in Ghana, and this has also given them a powerful alternative voice; i.e., a voice other than that of the state apparatus in politics.

This paper interrogates the Ghanaian media's depictions of Pastor Mensa Otabil and Archbishop Duncan-Williams, and also how they are viewed by some members of their churches interviewed for this study. The paper is a descriptive narrative of the strategies and pronouncements of these religious leaders of the two pioneering Pentecostal-charismatic churches in Ghana to underscore their alternative ideology within a broader discussion of the separation of church and state in democratic Ghana (Dovlo 2005).

\section{Religion and Politics in Ghana}

Religion is visibly ubiquitous in the Ghanaian public sphere. This is perhaps not surprising, given the growth of religious groups in the country. In 2000, $68.8 \%$ of the 19 million population of Ghana were Christian, 15.9\% Muslim, 8.5\% Traditional Religious Adherents, and 6.1\% reported affiliation with no religion (Ghana Statistical Service 2002). Ten years on, the 2010 Population and Housing Census Report indicated that $71.2 \%$ of the 24.6 million Ghanaian population profess the Christian faith, $17.6 \%$ Islam, 5.2\% traditional religion, and 5.3\% were not affiliated to any religion (Ghana Statistical Service 2002, p. 6). The Pentecostal-charismatic churches form a salient part of this religious map, together making up $28.3 \%$ of the population (Ghana Statistical Service 2012, p. 40).

Apart from the increasing construction of church edifices and mosques throughout the country, megachurches in particular continue to dot the urban skyline. Interestingly, a good number of the 
said churches have taken over the premises of collapsed industries, making the churches a symbolic representation of their failure. For example, the premises of Domalong Steel Company and Paramount Distilleries have been taken over by Royalhouse Chapel, while those of the Meat Marketing Board and Willowbrook Ghana have been taken over by Perez Chapel. In the same vein, Action Chapel today occupies land that President Kwame Nkrumah zoned into a light industrial area south of the Accra-Tema motorway. Moreover, the visibility of religion in Ghana goes beyond architectural structures and the display of religious activity by worshipers to the rather open discussion of religion in the media amidst a growing presence of religious leaders who ostentatiously seek to influence political culture in the country. As observed earlier, this is not unique to Ghana and its Pentecostal-charismatic churches; however, being new players in the field compared to the historic mission churches, the success of these churches in the influence they exert on the Ghanaian public sphere is remarkable and worthy of sociological analysis.

The December 2012 elections in Ghana were perhaps the most contested in the nation's recent democratic dispensation. Apart from the main opposition National Patriotic Party (NPP) challenging the election results in court, the electioneering campaign prior to the elections was itself fraught with acrimony to the point where even an individual person, Pastor Otabil, felt he was under attack. In other words, even without professing to be a politician, Pastor Otabil felt undue advantage was taken of him by a cross-section of the political spectrum for political gain. On 12 November 2012, he called a press conference to address what he said were "media references that seek to place my sermons and me in a partisan political position". His objective, he said, was "to clarify some misrepresentations of my sermons and to hopefully stop the running harassment against my integrity" (Otabil 2012).

Before addressing the main issue, however, Pastor Otabil seized the opportunity to spell out what great service he and his church have rendered to Ghana by operating "one of the largest non-governmental educational scholarship schemes in the country", providing "several needy people and communities with help", such as "portable water to people living in Buruli-ulcer endemic area", and building "a fully furnished boys dormitory for the Osu Children's home". He said the ICGC was "probably the largest private donor to the Children's Cancer unit of the Korle-Bu Teaching Hospital", and his "church operates the largest private university in Ghana with almost 10,000 students". In his own words, this service to his country emanates from the "spirit of generosity that was shown" him and his siblings in their "days of despair" as orphans. He sees himself as "a bridge builder", his ministry consisting in encouraging all people, "Christians of all shades, Muslims and a large segment of people who belong to different belief systems" (See Okyerefo 2018, 2011; De Witte 2003 for examples of the many works of Otabil and his church's business).

Pastor Otabil was blatantly insistent: "I am a pastor. I am not a politician. I am not standing for any political office. I am not a member of any political party". His complaint was that his "voice and sermons have been sampled, spliced and manipulated to appear to take a political position on a very heated political issue". He further stated: "I have also been made to appear as taking a stand against one political group or the other". He decided not to keep silent as he claimed he would normally do because he realised he "was dealing with a marauding and bullying force that was bent on impugning' his 'name and integrity without shame". His pulpit, he said, is not for partisan politics. Rather, his "messages have consistently spoken to the larger issues of hope, righteousness and justice". To this end, he called the acts of misrepresenting his sermons "defamatory", "unethical", "criminal", "malicious", "Machiavellian", and "evil", "a violation of my person and my integrity", calling on "all men and women of conscience" to resent it, "all people of faith-Christians and Moslems, Pastors and Imams-to demand for righteousness, justice and fairness in our national discourse", and "the President of the Republic to rise up and speak on this issue" as "the perpetrators of these blatant acts of impunity are largely affiliates and surrogates of your party".

On the one hand, this incident concerns an individual citizen seeking to exercise his right of freedom of speech to address what he considers an unjust treatment of his person. On the other hand, pronouncements of pastors of the stature of Mensa Otabil, as the one reported above by the 
media, are not mere individual overtures. They are directed at the public sphere to a political effect as poignantly visible in the above discourse. Any individual can call a press conference in a democracy; the question is whether the press will show up, and they did in this case as he had been misquoted. The response of the press is indicative of the moral authority Pastor Otabil wields in the Ghanaian public sphere even to a political effect. To this end, this paper examines the strategies and motivations that Pentecostal-charismatic religious groups, such as his and Archbishop Duncan-Williams' group, employ to access and influence political society in an increasingly diverse socio-cultural context in Ghana. The study explores how such influence of religious groups is directly disbursed through their pastors' sway on political culture in the country. The media report how the pastors take advantage of the overt participation of some political leaders in religious activities, as well as how their involvement with educational and financial institutions appear to grant them and their groups an enviable presence in the public sphere and favoured access to the corridors of state power.

\section{Theoretical Background}

Ghana's new churches do not want to simply acquiesce to the position of preaching the word of God as quiet pious groups but rather seek to engage society as an overarching force that exerts influence on the establishment, thereby engaging in an alternative ideology. This means that the cultural messages emitting from these churches constitute an alternative ideology, which is to say they seek to "influence governance" (interview granted by Rev. Dr. Michael Perry N.O. Tettey, Deputy General Secretary, ICGC, 18 April 2018) rather than simply proclaim the gospel and its preferential option for the poor. This alternative propels the churches to the echelons of power vis-à-vis the state, as defined by the dominant ideology of state political culture.

Clifford Geertz is "a notable advocate and an influential definer" (LaCapra 1988, p. 377) of culture. In his "Ideology as Cultural System" Geertz "applied his general concept of culture to the particular problem of ideology", criticizing "the reductionism of both the Marxist notion of ideology in terms of interest and the functionalist notion in terms of tension-management (or the reduction of "strain" (LaCapra 1988, p. 377). Huaco (1971, p. 248) has, however, criticized this "two-factor conception of ideology (as falsity and as social role)", offering a third element of ideology, duplication or isomorphism, besides the "interest" theory and "strain" theory. Huaco argues that isomorphism is more than a mere duplication; "it also sets the limiting assumptions of a class or an epoch". The three-factor notion of ideology, thus, allows sociologists to refrain from "a restricted usage of ideology as falsity and role" since "the isomorphic factor in ideology suggests that in every society, the 'common-sense' view of the world is one structured in terms of ideological myths" (Huaco 1971, p. 254). Such a structure makes the notions of a dominant ideology and an alternative ideology in society comprehensible. This study dissects the strategies and motivations of Action Chapel and ICGC to underscore their efforts to access and influence political society as an alternative ideology to the state's dominant secular ideology.

Comaroff and Comarof (2001, p. 3) extend this ideological argument by situating it within the framework of public culture "to animate further debate on the enigmatic nature of millennial capitalism, and also on its implications for theorizing history and society at the start of the 21st century", wishing "to characterize our current moment—as an age of death (of ideology, politics, the subject) or rebirth (of the spirit of Marx, Weber, the two Adams, Ferguson and Smith)—ours are perplexing times". Thus, the death and rebirth of Marxist ideology, for example, continues to characterize public culture today, which inures to the benefit of the "millennial capitalism of the moment: a capitalism that presents itself as a gospel of salvation" (Comaroff and Comarof 2001, p. 2) upon which, after all, the prosperity gospel of Pentecostalism thrives. Prosperity gospel invites the believer to trust in the saving power of Jesus Christ, who suffered, died and was resurrected to save human beings. Hence, in prosperity gospel lies the assurance of one's spiritual and material victory. It follows that the spiritual power of this faith makes possible the conquering of the temporal order, which is why the church can influence social order, including the state. The wealth and power generated from this religious movement catapults it into the public sphere, having garnered renewed confidence to influence state ideology not only in 
Ghana but also in particularly similar societies in the global South which share larger structural and historical characteristics.

Marshall (2009) asserts that Pentecostalism acts to assure Nigerians of political and religious salvation, a reality which Obadare (2018) extends in showing how Pentecostalism is usurping state power in the same country, Africa's largest democracy, to the extent of demobilising civil society. His vivid description of the Nigerian case corroborates Acheampong (2018) argument that Pentecostals in Ghana ${ }^{1}$ have moved out of their previous "enclave community status" to a novel "sustained political engagement" status wrought in "prophetic politics", giving credence to my contention that Pastor Mensa Otabil and Archbishop Duncan-Williams see themselves as fulfilling that prophetic role in the alternative ideology they offer vis-à-vis that of the state. This action is constructed through their public discourse to assuage public opinion that constrains state dominant ideology, with the dominant and alternative ideologies hereby defined as systems of governance.

In Gifford (2004, p. 48) view, "Faith Gospel, the Gospel of Prosperity, or the Health-Wealth Gospel" emanates from Pentecostal Christianity, which implies success in almost every field of life, economic, political, social. As churches of the Pentecostal-charismatic tradition, Action Chapel and ICGC are steeped in prosperity gospel theology, meaning the gospel of health and wealth. This theology extends the "gospel" the churches preach into an alternative ideology that seeks to participate in, influence or even exact the power of the state's dominant ideology of secular governance. As seen earlier, Karl Marx's work helps us understand that status and compensatory ideology (Huaco 1971) help to make sense of Pentecostal churches traversing the social class configuration in Ghana, giving the new churches an alternative voice to influence dominant politics. Building an overarching force to wield influence on the centre of power, the churches emit cultural messages characteristic of an exerting force on the establishment while at the same time profiting from the prestige and privileges such power bestows. I will show in the paper how the leaders' actions and pronouncements in the Ghanaian public sphere exert such force on the establishment.

\section{Method}

Action Chapel and ICGC were selected purposively according to their age and influence in the Ghanaian public sphere. Purposive sampling was an effective means of identifying specific religious groups whose spokespersons were interviewed (Bryman 2008). The images of the churches depicted in the media provided a major means of knowing and understanding how the churches operate. The media have their limitations in presenting objectivity, which is why as many and varied reportages as possible, as well as sources, were employed to complement each other. Seven media sources with a large following in Ghana and outside Ghana were selected and their content analysed. These included Citi Business News, Ghana New Agency, Graphic Online, Myjoyonline.com, Peacefmonline.com (2014), Radioxyzonline.com and Daily Guide. To counterbalance these media sources, one prominent leader each and six members each of the churches themselves were interviewed in fieldwork for the study. The prominent leaders were the Deputy General Secretary of ICGC and a Bishop at the Headquarters of Action Chapel, who were both chosen in view of their being at the centre of authority of their religious groups (it was not possible to interview the founders), while the members were chosen randomly. Similar questions were addressed to them in in-depth interviews to ascertain their views on their church's influence on the public sphere and governance. The questions included the following: "What would you say is the role of your church in the Ghanaian society?", "In what way would you say that your church contributes to the country's socio-economic development?", "What is your view on church/state relations?" and "In what practical ways would you say your church and its leaders influence politics in Ghana?". The interviews were held in Accra with members and leaders of the

1 I am familiar with the scholarly works of major scholars in the field, such as Birgit Meyer, but have chosen to focus on more recent scholars whose works speak more closely to my topic. 
selected churches between April and May 2018. The study is thus a qualitative analysis of information gathered on these churches from both within and without in order to guarantee a balanced view.

The study draws on my ongoing research into Pentecostal-charismatic churches in Ghana and their transnational engagement since 2007 (Okyerefo 2008). Beginning from February 2007, I have conducted fieldwork in Accra, deploying interviews and participant observation in addition to a perusal of media reports and written documents using content analysis (Okyerefo 2011). I also follow the activities of these religious groups even outside the framework of formal fieldwork, with particular analysis on their media presence in the country, and also their transnational networks in the global North (Okyerefo 2008, 2014). Content analysis of media is necessary, in addition to interviews, as the church leaders and members themselves do not easily admit to yearning for political influence. While the study will draw on two main cases to illustrate the said political influence, Archbishop Duncan-Williams' "cedi prayer" and Pastor Otabil's "Capital Bank saga", in view of the huge public discontent they generated, other examples will be used to buttress the argument, pointing to a developing system of public culture akin to an ideology surrounding these religious groups' nibbling at the centre of power. The "cedi prayer" touched on the heart of the nation's economic woes while the "Capital Bank saga" hinged on state law and affected the very livelihoods of people.

I argue in the paper that, although the effort expended by religious groups in Ghana to access and influence political power is not a historical novelty, sectional ambitions in respect of political access and influence have nevertheless recently gained ascendancy. This development is in response to the relatively rapid and large-scale growth of religious diversity across the nation and within its growing conurbations as a result of the proliferation of Pentecostal-charismatic churches. The scramble of Pentecostal-charismatic churches for access and influence is most clearly manifest in organizational strategies and the pronouncements of their leaders through the medium of the media. To this end, I assess the strategies and motivations of Action Chapel and ICGC in striving to access and influence political society in Ghana. Thus, the words and actions of perhaps the most influential Pentecostal-charismatic pastors (Pastor Otabil and Archbishop Duncan-Williams) are mostly the focus of this work since they are well known and central to the subject of the study.

Archbishop Nicholas Duncan-Williams is certainly a pioneer founder of a Pentecostal-charismatic church that wields a good deal of influence in Ghana. His Action Chapel is a household name in Ghana. His flamboyant life style and comments on issues of a controversial nature keep him constantly in the media. His Dominion University also belongs to the growing number of private universities in Ghana seeking to make their mark in the sphere of education.

Pastor Mensa Otabil is one of the most influential Pentecostal-charismatic leaders in Ghana. Founder and General Overseer of ICGC, his list of credentials include the setting up of a private university in Ghana, Central University-one of the few such private institutions to obtain a charter from the state. Pastor Mensa Otabil cherishes a Pentecostal faith that speaks to Africa's social needs, believing that the greatest potential of Africans is yet to be realized. Consequently, he seeks to promote a rigorous intellectual debate and teaching on various subjects relevant to this development. To this end, his weekly Living Word broadcast programme is listened to by many Ghanaians.

\section{Political Access and Influence}

As seen earlier, "Ghana was conceived as a secular state". However, "Christianity became the primary religion during the era of colonial rule", underpinning "many new laws guiding the State ever since" (Dovlo 2005, p. 629). Consequently, colonialism bequeathed Ghana with the historic Christian churches (Anglican, Methodist, Presbyterian, Roman Catholic) that wielded considerable influence on the Ghanaian public sphere. This was achieved largely through the schools they established and the moral authority they exerted on the Ghanaian public, thereby gradually eroding Traditional African Religion. The influence of these historic churches is evidenced, for example, in their reaction to the Religious Bodies (Registration) Law of 1989 (PNDCL 221). The fact that the Christian Council of Ghana (CCG) and the Ghana Catholic Bishops' Conference (GCBC) could stand up to the military 
government and refuse to register (Dovlo 2005, pp. 642-43) indicates how powerful these religious groups were. The numerous communiqués or pastoral letters of the GCBC or CCG also further support the effect of their influence. Moreover, President Mills, former Presidents Kuffuor and Rawlings, and several ministers and parliamentarians all attended the Catholic Church's second plenary assembly of the Regional Episcopal Conferences of West Africa (RECOWA), held in Accra, Ghana, from 22 to 29 February 2016.

As mentioned above, new players have since entered the field, changing the religious scene and deploying new strategies to exert influence on the Ghanaian polity. Dovlo $(2005$, p. 644) asserts that many "new religious movements, especially 'charismatic' Churches", began to proliferate "in Ghana beginning in the late 1970s", drawing "their membership mainly from the older churches", thereby changing the religious scenario remarkably. The greatest change took place in the urban areas. The Greater Accra Region, the most densely populated region with approximately 1236 persons per square kilometre (Ghana Statistical Service 2012, p. 2), undoubtedly has a remarkable religious landscape. The growing presence of Pentecostal-charismatic Churches is posing a challenge to the historic Christian denominations, both numerically and in terms of their visible presence in the public sphere.

The 2010 Population and Housing Census Report shows that the Roman Catholic Church remains the single religious denomination with the largest following in Ghana, with 3,230,996 adherents, comprising $13.1 \%$ of the Ghanaian population. The Protestant denominations together have 4,534,178 adherents, comprising $18.4 \%$ of the population, while the Pentecostal-charismatic groups in total, with their $6,980,792$ adherents, form $28.3 \%$ of the Ghanaian population. The Pentecostal-charismatic Churches have 1,786,519 adherents in Greater Accra alone, while there are only 892,537 Protestants and 300,446 Catholics in the same region (Ghana Statistical Service 2012, p. 40). This reality also supports the argument that Pentecostalism is largely an urban phenomenon. At the same time, however, the trend shows its growing presence in the rural areas as well.

Undoubtedly, this growing numerical presence of Pentecostal-charismatic churches gives them the confidence to exert themselves in the public sphere. Their mega churches are visible, especially in the cities, while they have a growing media presence. To "found mega churches is to found powerful constituencies", while the "transnational character of these churches promotes foreign earnings that are ploughed into development projects such as schools and hospitals" (Okyerefo 2011, p. 285), even universities, in a true spirit of the historic churches. Bishop Dag Heward-Mills of the Lighthouse Chapel International contends that megachurches pose a challenge to governments that are constantly looking for votes. He says mega churches mean "more contacts and 'connections' as many people can find jobs through the church" (Heward-Mills 1999, pp. 16-17). Added to their physical presence is their media presence. Asamoah-Gyedu (2007) underscores the huge media presence of Pentecostalism, characterising this brand of Christianity as a constantly changing reality that seeks to take full advantage of new technology.

In the style of the mega church and executing their mission through the media, it can be argued that Pentecostal-charismatic churches are making their presence felt in Ghana by affirming themselves in the corridors of power. Furthermore, while Pentecostal pastors are increasingly taking centre stage in making their presence felt in Ghanaian society, politicians are seen more and more in their churches-maybe to catch voters, as Bishop Dag Heward-Mills observes above? Indeed, the courtship between Pentecostal leaders and politicians appears to be a symbiotic one, with leaders from both spheres seeking to operate in each other's field of influence-the one to court votes and the other to share in political sway. In the Daily Guide headline of 3 December 2013 (Daily Guide 2013) Archbishop Nicholas Duncan-Williams told President John Dramani Mahama "Free The Money", referring to the economic difficulties in the country. President Mahama was attending a church service at Action Chapel-where the politicians go, there follows the press. This does not only include Ghanaian politicians-some foreign envoys have also discovered this new "wave", so that even though the late president Mandela was Methodist by religious affiliation and had a Methodist minister celebrate his funeral in his ancestral home of Qunu in South Africa, the South African High Commissioner in Ghana 
organized a special memorial service for Mandela at Archbishop Duncan-Williams's Action Chapel and not in any Methodist Church parish in Accra. Again, the president of the republic, John Mahama, was in attendance, as well as a "high patronage from former President Jerry John Rawlings, politicians, members of the Diplomatic Corps and Christians from other churches who joined the congregation of the host church to celebrate the life of the late South African leader" (Graphic Online 2014b).

Ghanaian presidents' flirting with Pentecostal-charismatic pastors caused a tidal wave during the regime of the late President Professor John Evans Atta Mills, a Methodist by Christian affiliation, who became enamoured with Prophet Temitope Balogun Joshua of Nigeria, popularly called T.B. Joshua. The media in Ghana reels with anecdotes on President Atta Mills' relationship with T.B. Joshua, who is said to have been the personal pastor-physician of the president and had unrestrained access to the seat of government, Christianborg Castle, whenever he wished. President Atta Mills is claimed to have testified that T. B. Joshua prophesied his ascent to the presidency (The PM News, Nigeria 2009). The president is also said to have paid several visits to the prophet's church in Lagos, in search for a cure to his ailment. In short, his relationship with T.B. Joshua generated a lot of media discussion in the Ghanaian public sphere, meeting with consternation in large segments of Ghanaian society. His critics felt that the president should have concentrated on exhibiting strong leadership and fixing the problems of the nation rather than trotting to pastors. Despite Ghana's characteristically huge religious public, the ambivalence of President Atta Mills' public display of religiosity and acquiescing to pastors met with disquiet. Indeed, public reaction to such attitudes is becoming increasingly so, especially when pastors pontificate on aspects of life which experts question.

A typical case in point is what is now referred to as Duncan-Williams' "cedi prayer". On Sunday, 2 February 2014 (Graphic Online 2014a), Archbishop Nicholas Duncan-Williams prayed that God should avert the depreciation of the Ghanaian currency, the cedi, and the spiral downturn of the economy at large: "I hold up the cedi with prayer, and I command the cedi to recover and I declare the cedi will not fall; it will not fall any further. I command the cedi to climb. I command the resurrection of the cedi. I command and release a miracle for the economy" (Radioxyzonline.com 2014b). While this prayer and his subsequent response to his critics is a message that strikes a chord with what some politicians possibly wished to hear in the face of mounting criticism regarding the government's management of the economy, Nicholas Duncan-Williams was severely criticized by a section of the public, including a few politicians. When criticized that "religion or prayer had no place in economic management and that the Archbishop should leave the management of the economy to economists", Duncan-Williams responded that "while he had no grip on the management of the national economy, he was a spiritual man whose concern was for the growth and prosperity of the country" (Graphic Online 2014a). He stressed that nobody had asked him to pray. However, "as a spiritual man, and looking at what is going on in other countries and the suffering of people... I'm praying from my perspective because I am a leader and I deal with people and I see what the people are going through". He went on to list his accomplishments: "I have a drug rehabilitation centre, an orphanage, I'm building schools which were under trees and churches all over the country that I care about. I know that if the economy gets well, it is in the interest of all of us. So to pray for the economy to get well, praying for the well-being of the economy and the cedi is Biblical and a good thing. If anybody is not managing the economy or the currency well, that is not my problem. I leave that to those in authority and those who voted them into office to deal with it. But that should not deter me from praying"' (Graphic Online 2014a).

Bishop Samuel Awuku Opare-Lokko of Action Chapel, whom I interviewed on 17 April 2018, said Archbishop Duncan-Williams' other title is the "Apostle of Prayer". He engages in "strategic prayer" in response to any situation or human predicament, which he (the Archbishop) believes God is capable of handling. Another member of the church interviewed (wishes to be anonymous) on 29 May 2018 believes that Action Chapel "complements the state". She explained further:

I think Action Chapel has been instrumental in politics, especially during the recent election petition hearing, especially when we got to a brink of collapse because of who has won the 
election and who has not won. The Archbishop was so key. So, Action Chapel through the Archbishop was part of the eminent leaders who brought all sides together including the Electoral Commission to ensure that.

Her comment was in reference to the dispute which ensued between the NPP and the NDC after the 2012 elections when the NPP brought the case to court.

Archbishop Duncan-Williams himself argued that "church and the state were inextricably linked and that for the past one hundred years Ghana's churches have played key roles in the development of the country". For him, "God is the governor of nations", "Abraham Lincoln, one of the greatest American presidents, declared fasting and prayer on three different occasions—on the last Thursday of September 1861, 30 March 1863 and in August 1864 for issues including national peace, national repentance and for people who held positions of authority, respectively" (Graphic Online 2014a). The Archbishop must be right in expressing this view as the US constitution was inherently based on Christian precepts. To this end, his view smacks of a church-state symbiosis in which dominant and alternative ideologies could influence and profit from each other, including a share in the power of the state. This is not uncommon, however, as the case of countries such as Saudi Arabia shows.

Duncan-Williams' "cedi prayer" re-kindled a discussion on the Ghanaian economy, with the Graphic newspaper highlighting the fact that 2013 was one of the worst years in recent history regarding the performance of the currency-the year closing with a $17 \%$ slump of the cedi against the dollar. This would lead to the Bank of Ghana pumping $\$ 20$ million into critical areas of the economy as part of efforts to shore up the cedi. The paper also reminded readers that "the cedi's battle of survival against the major trading currencies- the dollar, euro and the pound sterling-is part of the global crisis that has seen countries including Argentina, Turkey, South Africa, Brazil, India, Ukraine, Venezuela and Mexico struggle to keep their currencies afloat" (Graphic Online 2014a).

The staunchest critic of Duncan-Williams' prayer was Dr. Tony Aidoo, Head of Policy Monitoring and Evaluation at the office of the president. Describing Duncan-Williams' action as "comic relief" (Myjoyonline.com 2014), he believed that "attitudinal change and a change in the structure of the economy are the requirements to stabilise the cedi and not prayers". However, others rose to the defence of the pastor or continued to prophesy regarding the currency. Rev. Titi Offei believed Tony Aidoo's comments were, at best, hypocritical. He could not reconcile Tony Aidoo's silence over the late President John Atta Mills' invitation to pastors to pray at the Castle- the seat of government-every morning, with his critique of Duncan-Williams. Rev. Titi Offei was also critical of Tony Aidoo for saying nothing about politicians running to churches and to pastors for prayers prior to elections only to turn away from the said pastors when they win power.

It is against this backdrop that the Bank of Ghana, as per its directive reference BG/GOV/SEC/2014/02 to all banks, revised its rules for operating foreign exchange accounts (FEA) and foreign currency accounts (FCA) with effect from 5 February 2014, as part of its measures to stabilise the performance of the cedi (Bank of Ghana 2014). While this directive may have nothing to do with the prayers and pronouncements of the Pentecostal pastors under discussion, it does point to the fact that these individuals make it a point to speak to issues affecting the nation. Duncan-Williams' immediate and public reaction to the directive points to his determination to continue to play a key role in the public sphere. On Sunday, 9 February 2014, his church (Radioxyzonline.com 2014b) ordered congregants "to stop issuing dollar cheques for offertories, tithes and other payments" and issue "only cedi cheques". Duncan-Williams publicly called on his church to adjust to the measures for practical reasons as it was unlikely the Bank of Ghana would honour foreign currency cheques. He would go on to be become a government appointee to serve on the Council of the University of Ghana, the nation's premier university, from 2 August 2016 to 7 January 2017 (Registry of the University of Ghana 2018) when the council was automatically dissolved with the assumption of power by the newly-elected NPP. It should be noted that he was appointed by the NDC government of President John Mahama. Archbishop Duncan-Williams, however, would seem to continue to enjoy the respect of some high-ranking officials of the new NPP government of President Nana Addo Dankwa Akufo 
Addo. Indeed, as I arrived at the premises of his cathedral, university and office complex for my research interviews on 17 April 2018, I was closely followed by the motorcade of the Inspector General of Police (IGP), David Asante-Apeatu, who went into a closed-door meeting with the Archbishop and was still there when I left after conducting a one-hour interview. When I made a friendly remark to my interviewee, Bishop Samuel Awuku Opare-Lokko, regarding what a "very important person" his Archbishop must be for the IGP to visit him, he responded with elation: "this answers what your research is seeking to know about Action Chapel's influence on political culture". Obviously, Bishop Samuel Awuku Opare-Lokko, as a leader in the church, must be conscious of his church's determination to be that alternative voice that should constantly nibble at the state's own.

In a similar vein, Pastor Mensa Otabil's nibbling with the power of government is exemplified in the Capital Bank saga. Pastor Otabil was Chairman of the Board of Capital Bank, which collapsed in 2017. The bank is purported to belong to a consortium including him and a number of his church members, some of whom were shareholders and board members at the same time. The published memo of the former CEO (Former Capital Bank CEO's 2014 memo) predicting the collapse of the bank reveals unorthodox operations of the bank that were obviously not addressed (Chief Executive Officer 2017), despite the CEO's stark warning. This evidence is a further reason that some Ghanaians would be surprised that, in spite of what verges on financial malfeasance, the Ghanaian public sphere is yet to learn of the truth in the Capital Bank Saga and whether any individuals found culpable would face disciplinary measures. Given the purported interest of the Bank of Ghana to issue a $\mathrm{GH} \pitchfork 2 \mathrm{bn}$ bond to clear Capital Bank and UT bank (CitiBusiness NEWS 2018), it is natural for the tax payer to be concerned. Members of the ICGC, however, believe their mission to be influencing society positively. One member interviewed on 23 May 2018 said that "ICGC in a way is trying to develop a mind-set in Africans that they are capable in doing things on their own. So that we don't become so much dependent on foreign government so that every time we want to sit down and be expecting the foreign government to come". This thinking should be credited to Pastor Otabil, an astute motivational speaker who is skilled at educating his church members and the public. His strategy has propelled ICGC's political engagement into an alternative ideology, which thrusts the church into the limelight. Indeed, he himself has become such an eminent Ghanaian, warranting his membership on the first Board of the National Peace Council of Ghana in 2011, a statutory board.

In Ghana, pastors simply dare to pontificate or make pronouncements on anything, from economic to security matters-areas one would think are the preserve of the secular state and its experts. The pastors make such pronouncements usually in their churches, during their sermons, and in the public sphere, where the media is present to carry them into the outside world. Indeed, the failure of the state in the provision of jobs and social services, as well as giving the citizenry a sense of purpose, for example, constitute some of the reasons why people look to churches for leadership. The examples in the paper corroborate how, in common parlance in the Ghanaian banking sector, some individuals are profiled as Politically Exposed Persons (PEP). The founding of churches constitutes an area of public life in which the state has failed to provide regulation, which is why any person, irrespective of qualification, can found a church. In other words, in Ghana, one does not need to have theological training to found a church. It solely devolves on any individual feeling of being "called" for the purpose or perhaps "hearing voices" of commission. Consequently, this is an aspect of the Ghanaian public sphere where individuals confer titles on themselves-titles that seem to be recognized by society. In no other area of public life is this possible, yet service is sought by members of the public in such religious institutions-a service which is rendered and at the same time opens up avenues for abuse.

When pastors make pronouncements in the interest of the government, their action is well received by politicians. President John Dramani Mahama is said to have proclaimed "Don't tag religious leaders as partisan" (Radioxyzonline.com 2014a). In fact, the President would go so far as to institute a "National Week of fasting, prayer and thanksgiving", beginning from 2014, to be "organised by the Christian community, in collaboration with the government. A meeting to discuss the maiden 
programme took place at the Banquet Hall of the Flagstaff House "when the President hosted the senior clergy to a breakfast meeting" (Graphic Online 2014c). By the same token, one of the major projects President Akufo-Addo sought to implement soon after taking office was that of constructing a National Interdenominational Cathedral-a project that has met with much controversy in the country in view of the principle of the church-state separation required in a modern democracy.

By their actions and pronouncements, pastors like Archbishop Duncan-Williams and Pastor Otabil are keenly aware that the ultimate power they wield results from setting themselves as an alternative ideology against the dominant ideology of state power if only to exact part of it. Thanks to the prosperity gospel—-the health-wealth theology they propound-their churches have become immensely wealthy, thereby enjoying prestige and influence, but also critique in Ghanaian society. The penultimate aspect consists of sharing in the state's power of governance or presenting themselves as an alternative to it. Thus, the churches, in part, assume the structures of the state. The main examples enumerated in this study — the "cedi prayer" and the "Capital Bank saga" — as well as their various corollaries are indicative of what Comaroff and Comarof (2001, p. 2) term the "millennial capitalism of the moment: a capitalism that presents itself as a gospel of salvation". The prosperity gospel of Pentecostalism is a brainchild of this development, whose fruits include wealth, power and prestige-cherished values which Pentecostal-charismatic churches in Ghana seek to project into the limelight. The desire to influence and set themselves against or act in tandem with the state apparatus, I argue, consists of an ideological system which presents an alternative to the dominant state ideological power.

It is not uncommon for founders of some Pentecostal-charismatic churches in Ghana to be referred to as "General Overseer", which is akin to the "Commander in Chief" of the state. Their lifestyles exemplify this status when they move about under the protection of their own security agents and their wives are referred to by church members as "First Lady" of the church, which suggests that the founder is "president". This verges on the tendency of Pentecostal-charismatic church leaders to operate as the president of an African nation-state. In my interaction with Action Chapel members, they referred to Archbishop Duncan-Williams informally as "papa", while some ICGC members call Pastor Otabil "the Founder", although they themselves said he dislikes titles, preferring simply the prefix "pastor". Consequently, it lies within the competence of the "founder", the "president" of the church, to call a press conference as Pastor Otabil did in 2012 or for the IGP to pay a courtesy call on Archbishop Duncan-Williams for a closed-door meeting on 17 April 2018. Again, being in the good books of a particular government could earn a pastor the position of member of a University Governing Council, specifically a government appointee on the Council. To what extent will clients of the collapsed Capital Bank receive justice from the dominant ideology? This question can only be answered at the end of due process.

\section{Conclusions}

The concrete strategies and motivations employed by the leaders of Action Chapel and ICGC are in consonance with prosperity gospel churches. Prosperity gospel essentially positions itself against the centrality of the cross in the path of salvation as espoused by most historic churches and is thus a significant factor in the undue political influence sought by leaders of Pentecostal-charismatic churches. State dominance is wrought through competing ideologies-the overriding one controls social actors at any point in time. However, the actions and strategies of Action Chapel and ICGC point to the fact that they can meet state ideology with an alternative ideology in the prosperity-driven capitalistic culture of the moment. Such thinking makes it possible for Archbishop Duncan-Williams to believe that praying for the cedi would make Ghana succeed where the state had failed to fix the economy, or at least that his action could complement the efforts of the state. Again, a similar conviction makes Pastor Otabil call a press conference to influence the supposed narrative of the state or people closely working for it. By the same token, by being close with state actors, Archbishop Duncan-Williams gets to serve on the University of Ghana Council as government appointee while Pastor Otabil appears to 
enjoy less state torment in the face of leading a financial institution to its collapse. The churches find in an alternative ideology a confidence to tread even beyond their competences or areas of expertise by trusting God, who can make everything possible through them (see Okyerefo 2006/2007, 2011).

An important discovery of the study is the fact that the state apparatus, with its dominant ideology, is difficult to match with an alternative. The context of Pentecostal-charismatic Christianity within the increasingly diverse socio-cultural context in Ghana is awash with prosperity gospel, which is characterised by the capitalistic culture of the moment. The implications of this research in understanding specifically Pentecostal-charismatic engagement thus point to a further blurring of church-state separation within the scramble for the centre. Any desire for power easily makes the church oscillate between pushing an alternative ideology and an association with the dominant ideology. The courtesy call paid by the IGP on Archbishop Duncan-Williams is an example of this power play between the dominant ideology and alternative ideology. Compared to those of other religious communities, a moral alternative demands courage and patience, which means that influencing state ideology will most likely be a long-term project, which would suggest itself to be the approach of the historic churches.

The strategies of Action Chapel and ICGC to sustain the said alternative ideology thus include the following: first, a strong media presence, typified in Pastor Otabil's press conference or his weekly teaching "the Living Word"; second, their discourses on economic, social and political issues as exemplified in Archbishop Duncan-Williams' "cedi prayer" or Pastor Otabil's involvement with Capital Bank, alongside the employment their universities or other institutions offer citizens; third is their direct personal engagement with government officials and the general invitation of government officials to their churches. The efforts Action Chapel and ICGC expend on all these actions send out a strong message that they are key actors that cannot be ignored by the state.

Funding: This research received no external funding.

Conflicts of Interest: The author declares no conflict of interest.

\section{References}

Acheampong, Fredrick. 2018. Pentecostals and Politics in Ghana's Fourth Republic: From Enclave to Engagement. Ph.D. Thesis, Victoria University of Wellington, Wellington, New Zealand.

Asamoah-Gyedu, Kwabena Johnson. 2007. "Get on the Internet!" Says the LORD: Religion, Cyberspace and Christianity in Contemporary Africa. Studies in World Christianity 13: 225-42.

Bank of Ghana. 2014. BOG Directive-Foreign Account Operations. Accra: BG/GOV/SEC/2014/02 to all Banks, 2.

Bryman, Alan. 2008. Social Research Methods. New York: Oxford University Press.

Chief Executive Officer. 2017. Urgent Action to Salvage the Reputation and Fortunes of First Capital Plus Bank: August 11, 2014 Board Memo to Chairman and Members, Board of Directors. August 16. Available online: http://citifmonline.com/2017/08/16/former-capital-bank-ceos-2014-memo-predicting-collapse/ (accessed on 27 May 2018).

CitiBusiness NEWS. 2018. BoG Justifies GHф 2bn Bond Issue to Clear UT. Accra: Capital Banks Liabilities.

Comaroff, Jean, and John L. Comarof. 2001. Millennial Capitalism: First Thoughts on a Second Coming. In Millennial Capitalism and the Culture of Neoliberalism. Edited by Comaroff Jean and John L. Comaroff. Durham and London: Duke University Press, pp. 1-56.

Daily Guide. 2013. Free the money-Duncan Williams tells Mahama. Daily Guide, December 3.

De Witte, Marleen. 2003. Altar Media's Living Word: Televised Charismatic Christianity in Ghana. Journal of Religion in Africa 33: 172-202. [CrossRef]

Dovlo, Elom. 2005. Religion in the public sphere: Challenges and opportunities in Ghanaian lawmaking, 1989-2004. BYU Law Review 3: 629-58.

Ghana Statistical Service. 2002. 2000 Population and Housing Census: Summary Report of Final Results; Accra: Sakoa Press Limited.

Ghana Statistical Service. 2012. 2010 Population and Housing Census Report; Accra: Sakoa Press Limited. 
Gifford, Paul. 2004. Ghana's New Christianity: Pentecostalism in a Globalizing African Economy. Bloomington: Indiana University Press.

Graphic Online. 2014a. Duncan-Williams Defends Cedi Prayer. Graphic Online, February 4.

Graphic Online. 2014b. Let's End Acrimony along Ethnic Lines-Mahama. Graphic Online, January 27.

Graphic Online. 2014c. Week of Fasting, Thanksgiving to be Instituted. Graphic Online, March 18.

Hastings, Adrian. 1994. The Church in Africa: 1450-1950. Oxford: Clarendon Press.

Heward-Mills, Dag. 1999. The Mega Church. Accra: Parchment House.

Huaco, George A. 1971. On Ideology. Acta Sociologica 14: 245-55. [CrossRef]

LaCapra, Dominick. 1988. Culture and Ideology: From Geertz to Marx. Poetics Today 9: 377-94. [CrossRef]

Marshall, Ruth. 2009. Political Spiritualties: The Pentecostal Revolution in Nigeria. Chicago: University of Chicago Press.

Myjoyonline.com. 2014. Make Duncan-Williams Next President to Solve all Our Problems_Pratt. Myjoyonline.com, February 4.

Obadare, Ebenezer. 2018. Pentecostal Republic: Religion and the Struggle for State Power in Nigeria. Chicago: University of Chicago Press.

Okyerefo, Michael Perry Kweku. 2006/2007. Trust God! Religious expression at the University of Ghana. Ghana Social Science Journal 3-4: 1-2, 18-32.

Okyerefo, Michael Perry Kweku. 2008. Ausländer! Pentecostalism as Social Capital Network for Ghanaians in Vienna. Ghana Studies 11: 77-103.

Okyerefo, Michael Perry Kweku. 2011. The Gospel of Public Image in Ghana. In Christianity and Public Culture in Africa. Edited by Harri Englund. Athens: Ohio University Press, pp. 204-16.

Okyerefo, Michael Perry Kweku. 2014. Transnational Dynamics in African Christianity: How Global is the Lighthouse Chapel International Missionary Mandate? Journal of Africana Religions 2: 95-110.

Okyerefo, Michael Perry Kweku. 2018. Philanthropy as Image Politics in Ghana's New Churches. Journal for the Study of the Religions of Africa and Its Diaspora 4: 99-112.

Otabil, Mensa. 2012. Press Statement. Adom News, November 12.

Peacefmonline.com. 2014. Rev Korankye Ankrah Warns of "Wicked People" Infiltrating Ghana. Peacefmonline.com, January 2.

Radioxyzonline.com. 2014a. Don't Tag Religious Leaders as Partisan-Mahama. Radioxyzonline.com, March 17.

Radioxyzonline.com. 2014b. Duncan-Williams Orders Congregants to Pay Offertory in Cedis. Radioxyzonline.com, February 9.

Registry of the University of Ghana. 2018. Archbishop Nicholas Duncan-Williams' Term on the Council of the University of Ghana. Personal communicatio, May.

The PM News, Nigeria. 2009. 'T.B. JOSHUA PREDICTED MY VICTORY - GHANA'S LEADER'. Available online: https://www.scoan.org/blog/2009/06/04/t-b-joshua-predicted-my-victory-ghanas-leader/ (accessed on 10 December 2019).

(C) 2019 by the author. Licensee MDPI, Basel, Switzerland. This article is an open access article distributed under the terms and conditions of the Creative Commons Attribution (CC BY) license (http://creativecommons.org/licenses/by/4.0/). 

Article

\title{
The Social Architecture of Belonging in the African Pentecostal Diaspora
}

\author{
Rafael Cazarin $(D$ \\ Department of Sociology, University of the Basque Country (UPV-EHU), 48940 Bilbao, Spain; \\ rafael.cazarin@ehu.eus
}

Received: 8 February 2019; Accepted: 16 July 2019; Published: 18 July 2019

\begin{abstract}
From megachurches in movie theatres to prayer groups held in living rooms, Pentecostals worldwide are constantly carrying out religious activities that ultimately aim to integrate diverse worshippers into the kingdom of God. Born-again Christians refashion their 'ways of being' by breaking down and re-establishing the interpersonal relationships shaped and changed by emerging diasporic modernities. I examined some of these changing ways of being by comparing the discursive practices of African Pentecostal pastors in Johannesburg (South Africa) and Bilbao (Spain). These case-studies demonstrate how these migrant-initiated churches create a 'social architecture', a platform on which African worshippers find social and spiritual integration in increasingly globalized contexts. I argue that the subdivision of large congregations into specialized fellowship groups provides African migrants with alternative strategies to achieve a sense of belonging in an expanding diasporic network. Their transformative mission of spiritual education, by spreading African(ized) and Pentecostal values according to age, gender, or social roles, helps to uplift them from being a marginalized minority to being a powerful group occupying a high moral ground.
\end{abstract}

Keywords: identity; African Pentecostalism; integration; transnationalism; diaspora

\section{Introduction}

When looking at a world map or listening to the daily news, we imagine that territory and culture are marked by apparently static geopolitical divisions. But such assumed isomorphism of territory and culture is problematic when looking at those who live across such borders (Gupta and Ferguson 1992), or along what Gloria Anzaldua (1987, p. 3) calls that 'narrow strip along steep edges'. It has long been the case that scholars of migration, diaspora, and transnationalism treat culture and territory as constructs that are neither static nor isomorphic. Rather, their studies show how rituals and social processes can 'fill up' spaces with complex meanings, practices, and experiences, subverting hermetic notions of the local, global, indigenous, foreign, traditional, and modern (Anderson 1991; Clifford 1997; Levitt and Schiller 2004).

In this vein, most religions are not limited by geopolitical borders, but seek to transcend these material boundaries by cultivating and disseminating a particular worldview and ethos. Although Christianity has its historical connections with specific nation states, the idea of the gospel is that it cannot be contained or bound by a single person or place. Rather, the gospel is understood by believers as a Christian message that must be revealed to the world in multiple places and varied forms see (Sanneh 1989). Pentecostalism, especially, has spread transnationally in our global era while maintaining considerable cross-national connections. It fits well with a new world order in which national affiliations do not fully explain how a person's identity is socially, symbolically, or materially constructed (Marshall 1998).

In the case of African Pentecostals, migrants do not cut off ties to their homelands, but instead establish trans-territorial networks in and beyond the African continent (Adogame 2004). The internationalization of 
commercial goods, activities, people, and ideas has inspired Pentecostal churches to produce modernized versions of transnational religious communities. These churches are neither limited by colonial powers and authorities, nor strictly characterized by specific ethnonational identities. Static notions of culture dissolve as transnational mobility creates new forms of cultural and religious belonging (Gerloff 1995; Hunt 2002; Levitt 2007).

The churches examined in this study are structured around a flexibility of religious meaning, discourse, and practice. Religious leaders help build communal and individual spaces within their churches by engaging with the tensions and challenges experienced by migrants in a diasporic context. These lived experiences shape how people attain a subjective sense of belonging to one or more communities. I argue that such the religio-cultural construction of belonging is parallel to the notion of 'social architecture': the conscious design of a space that forges particular human responses, feelings, emotions, memories, behaviours, and discourses ${ }^{1}$.

In this article, my arguments draw upon ethnographic fieldwork conducted in six migrant-initiated Pentecostal churches, three in Bilbao (Spain), and three in Johannesburg (South Africa). These churches were mostly, if not exclusively, attended by migrants coming from Central and West African countries. I examined biographical narratives from in-depth interviews conducted with ten pastors of the selected churches in both countries. In addition, I participated in these pastors' church services and observed their public narratives, which I compared with their private ones. As holders of an institutional position of power and as experienced migrants themselves, I see these church leaders as creating a shared social architecture for their religious communities.

Despite their differences (denominational, ethnic, national diversity, etc.), each of these congregations divided itself into smaller subgroups or specialized fellowships patterned by cohort variables such as gender, age, and the spiritual gifts of individuals. This reveals an African Pentecostal social architecture that forges spaces of belonging for worshippers in diasporic contexts. Three strategies guide this process: (1) the division of the larger church community into smaller fellowships aimed at providing socially transformative missions to worshippers and pastors; (2) the (re)configuration of migrants' African and Pentecostal values to bring about purposeful roles within the church community and wider society; (3) the creation of family-like bonds and morality-based relationships in the congregation, which reshape worshippers' ethnic diversity into an African and Pentecostal melting-pot, centred on the moral restoration of broken societies.

I argue this three-dimensional approach helps to integrate worshippers into an African Pentecostal frame of reference. That frame makes sense of group dissonances by challenging the wider society to conform to more spiritually driven and morally bounded relationships. This social architecture is thereby able to elevate a marginalized minority to a higher moral ground, given their transformational spiritual mission. In this way, no matter where they live, African Pentecostals see themselves belonging to a group that holds desirable features or the 'right' formulas for dealing with the distresses of the present world.

\section{Methodology}

Pentecostalism is known for its linguistic, racial, ethnic, national, and cultural diversity typified by the use of multiple languages in church services and the formation of independently initiated congregations. The size and infrastructure of Pentecostal churches ranges from small garages, office spaces, and industrial pavilions to new commercial buildings, old theatres, and cinemas. The latter venues are often used by religious institutions that have large organizational boards of leaders; the former set of venues tend to host smaller cohorts. But besides size and structure, what connects

1 This definition is a reinterpretation of the expression 'social architecture' defined by 'The Oxford Dictionary of Architecture' (Curl and Wilson 2015) as the 'architecture intended for use by the mass of people as social beings as a reaction against architecture concerned with form and style supposedly for the dominant members of society'. 
Pentecostalism on a worldwide basis? Do global, continental, or local traits connect or differentiate African, North American, or Latin American versions of Pentecostalism?

This research project was initially conceived to explore the phenomenon of migrant-initiated churches in an autonomous community of the Basque Country, in Northern Spain. I chose the largest city of this region, Bilbao, and its metropolitan area, to conduct my fieldwork. I selected three churches located in the districts of Ibaiondo and Errekalde - the areas with the highest percentages of foreign nationals within the municipality of Bilbao. ${ }^{2}$ The churches were geographically close to each other and mainly located in working-class regions.

The initial phase of the fieldwork concentrated on a Nigerian-led church, the Hand of God Ministries International; it was considered to be the largest African Pentecostal congregation in Bilbao. From 2011 to 2012, I regularly visited this community and attended weekly services and meetings of the smaller fellowship groups. I was introduced to Apostle David ${ }^{3}$, the church's founder and his wife and women's fellowship leader Pastor Irene. I also met Edward, a resident pastor and leader of the youth fellowship.

In an effort to extend my observations to different contexts, I also visited other churches with more or less analogous characteristics (i.e., number of pastors and attendants, industrial building, national background of interviewees). By 2012, I had selected and visited two more churches in Bilbao. One was led by a Pastor Kando, a Congolese migrant who founded the Misión Evangélica de la Reconciliación in 2009; the other was Christ the Rock Ministries, founded by Pastor Ehis, a Nigerian national, in 2010.

Over one year of observation, I repeatedly heard pastors speak of their participation in transnational religious networks, especially those connected to Africa. In order to enrich the transnational dimension of my study, I decided to undertake fieldwork in migrant-initiated churches located in the African continent. A 2013 six-month research stay in Johannesburg, South Africa, allowed me to select three more migrant-initiated churches for comparison with my Spanish cases.

Like Spain, South Africa is an important migratory hub, hosting one of the largest groups of Christian migrants on the African continent. ${ }^{4}$ The first of my three churches was the Bread of Life Foundation, led by Congolese Pastor Steven and his assistant Pastor Richard. It was located in the area of Honeydew. The second was Diplomat's Assembly, led by Nigerian Pastors Victor and Emmanuel; it was located in Strydompark. Finally, La Louange was a Congolese-led congregation located in the suburb of La Rochelle, where I met Pastor Esther and Pastor Alfred. The three suburbs are geographically distant but evoked a similar cityscape to their Spanish counterparts: all were semi-peripheral areas zoned for services with industrial warehouses, offices and garages.

In total, I collected twelve life course narratives from these pastors: five males and one female in each city. All were between the ages of 30 and 55 years. Outside the church, they were employed low-skilled temporary jobs or in informal businesses. This was despite most of them claiming to have attended university and in some cases to have finished degrees in such fields as economics, engineering, and teaching. I did not choose the pastors based on their nationality; instead, my sample's national diversity emerged from a mix of snow-ball sampling and my explorations of church services and interdenominational conferences that I found announced on local posters and flyers.

This diversity is nonetheless important. Claudia Währisch-Oblau (2009, p. 47) demonstrates how current understandings of the intersectionality of church members' nationality and denominational

2 Source: (Ayuntamiento de Bilbao 2017).

3 Oral consent was obtained and recorded at the beginning of all of the interviews in which respondents were provided with a summary of the research project. This procedure followed the ethical guidelines of the American Anthropological Association for Institutional Review Board in Ethnographic research (Section 6, 4th Paragraph) available at https://www. americananthro.org/ParticipateAndAdvocate/Content.aspx?ItemNumber=1652. All the interviewees mentioned in this article agreed in being quoted using their 'stage names'. The use of 'stage names' is justified by interviewees as part of the born-again process and/or when they assume a position of leadership. In this way, born-again Christians adopt names from Biblical characters they admire, as well as to inspire and show others their acquired spiritual gifts, charismatic skills and Christian path associated to such biblical names.

4 Source: (Pew Forum on Religion \& Public Life 2012). 
identity remain inadequately explored in academic literature. She states that, 'while some churches are clearly mono-cultural and mono-national, others are multicultural and multinational'. The importance of multinational identity among Pentecostal members in Spain and South Africa became apparent in my data, as my six congregations had members from a variety of cultures spread across many nation state borders.

The pastors I interviewed also embraced these members' different cultural backgrounds as part of the church's wider rich diversity. A Nigerian pastor in South Africa rejected the label of migrant church, mentioning that around sixty per cent of his congregation were South African nationals. Later on, the pastor offered an alternative understanding of migrants by suggesting that worshippers were diverse in the sense that they also come from various South African provinces and cultural traditions. It was then that I decided to focus my study on small, ethnically diverse African Pentecostal churches in Spain and South Africa. This sample of churches hold visible differences when comparing my interlocutors' trajectories, narrations, and practices. Yet, the fieldwork reveals that in both cases of Johannesburg and Bilbao, similarities are more important than divergences. Despite the ethnic, national and societal divisions involved in both contexts, the sharing of African and Pentecostal components among these populations established a social architecture, a common organizational strategy, which guides preaching narratives and the social division of the congregation and that encapsulates religious experience into (de)localised senses of community.

My approach to these multiple and diverse spaces echoes what Ghassan Hage described as a 'single geographically discontinuous site' (Hage 2005). He problematized the concept of multisitedness in ethnography when studying migrants who share a certain unifying culture across a number of global locations. I take Hage's perspective to frame the unique socio-religious landscape in which the case-study participants were immersed. The discontinuous site here is the pervasive social architecture of churches within a diasporic African Pentecostal network that makes it possible for worshippers to feel a sense of belonging in geographically distant localities. This can be a church service where an elder Congolese pastor coherently engages with a young Nigerian preacher and a female Spanish evangelist in Bilbao; this can be an interdenominational conference about female empowerment held in Johannesburg, where a South African female evangelist and a Congolese male pastor explain the 'spiritual wonders' of the female body. In other words, the familiarity with African(ized) and Pentecostal repertoires engenders the necessary fluidity pastors practice when developing their missions and visions on a worldwide scale and in local contexts.

\section{3. (De)localizing African Pentecostalism}

In previous decades, an extensive body of academic literature has discussed several approaches for 'achieving' and catalysing the integration of migrants to a determinate society (Hepburn and Zapata-Barrero 2014; Houle and Comunicació Presentada al II Seminari 2000; Koenig 2005). These strategic policies have turned 'integration' into a capacious concept vastly explored in social sciences with regards to public policies, social interventions, and international cooperation programmes in the global North. That said, migratory processes are not a phenomenon that is exclusively determined by nation state policies. While their impact is not limited to developed countries, human mobility remains largely significant in South-South dynamics, where complex rural-urban or intra-continental flows are observed throughout history (Skeldon 2014, p. 70).

The decreasing moral legitimacy of governmental structures and political institutions shows that it is precisely within the spatial interstices of urban areas that integration plays an essential role. Such spaces are often seen as failures of urban development in that they lack 'healthy public space', and can be understood as 'anti-public space' (Brighenti 2013, Introduction). From migrant neighbourhoods to ethnic businesses and informal markets, these interstices or social spaces of differentiation are sometimes known as marginalized, heterogeneous, mixed, familiar, and delocalized. They appear to be a communal alternative to the organization of a fragmented reality, where intersubjective experiences and cultural values are negotiated (Bhabha 1998). 
In particular, within the urban perimeters of either African or European major cities, Pentecostal Charismatic churches seem to forge rich spaces for worshippers to wrestle with the global and local tensions that arise in their migratory processes. In this regard, anthropologist Simon Coleman used the term 'part-cultures' to analyse the theological ambivalences of Pentecostal Charismatics. For the author, 'their self-consciously globalizing manifestations' present worldviews meant for export that are holistic in one sense but, as we have seen, also in tension with the values of any given host society' (Coleman 2000, p. 11).

These 'part-cultures' offer a way to form transnational belonging, a bridge between the 'here' and the 'there', as well as a connection between past and present, tradition and modernity. In some cases, this religious practice involves attending a specific congregation where the doctrine, leadership, and structure are clearly established. But in other cases, there is no sense of belonging to a particular congregation, nor of personal devotion to a particular doctrine or leadership; religious experience can be developed in any church nearby (Levitt 2007). These ready-to-hand churches become a space in which the transnational experiences of worshippers acquire meaning, a place where migratory processes become relatable through the sharing of gendered, classed, racialized, generational, or spiritual experiences in both 'origin' and 'destination'.

Pentecostals favour these two different approaches — the established and the ready-to-hand - precisely because Pentecostalism is not composed of a unified theology. Scholars have often remarked that this is the 'key' to coping with modernity and globalization in religion today. Pentecostalism's distinctive characteristic among major religious groups is that it embraces and accommodates global exchange and change. Different streams of theological interpretation or approaches within Pentecostalism resist the idea of a sole doctrinal system guided by a particular logic (Hollenweger 2004, p. 129; Pinnock 2000).

In the global amalgam of different ethnic, national, linguistic and racial groups, human bodily and emotional experiences are reworked as transcendent languages that facilitate the incorporation of the many voices of 'the local' (Wilkinson 2011, p. 42). Pentecostalism's theological diversity and its cultural mosaic find common ground in the experience of the supernatural, as the manifestations of the Holy Spirit are embedded within and emerge out of the body.

In this regard, Roswin Gerloff (1995) argues that the non-white Pentecostal Charismatic movement offers a series of responses to traditional Christianity in which experiential aspects of religion play a greater role than does dogma, rhetorical arguments, or rational treatises. Gerloff calls attention to the strong faith that emerges with a renewed sense of independence from hegemonic Westernized Christianity and that takes seriously structural marginalization, exploitation, and oppression.

Pentecostal movements in Africa long proclaimed a biased history that entrusted Western institutions, leaders, and experiences with the responsibility of defining what constitutes fact and consequences. This offered a misleading framework for understanding how African Pentecostals developed independently from Western missionaries (Gaiya 2002; Jesse 2014; Kalu 2008, 2009; Ndung'u 2009). Until the late 1990s, the majority of studies done on the history of Christianity in Africa focused exclusively on white Christian missionaries' role in evangelizing Africans, rather than looking at African evangelists themselves (Kalu 2009).

Though international media depictions of Pentecostals focus mostly on white North Americans Pentecostals, Pentecostalism in the non-white global South accounts for up to three quarters of born-again Christians worldwide (Pew Forum on Religion \& Public Life 2006). Instead of relying on the 'application of imageless ideas exported from the West', anthropologist James Fernandez (1978, p. 215) argued that scholars should be 'beginning with African images and, by careful methodology, learning what they imply-what is embedded in them'.

Pentecostal Charismatic movements in Africa are interactive and should be understood independently from Western historical accounts of Christian missionary work. Their social architecture of belonging and membership is a process of layered integration of migrants into church spaces. This describes a distinctive response by African Pentecostals to modernity and the complex migratory processes that take place on the African continent and in the African diaspora. With its historic 
background involving racial, social, political, and cultural dynamics, these Pentecostal congregations become what Emmanuel (Akyeampong 2000, p. 209) defined as 'important spaces for the establishment of kinship and family networks while extending the emotive religious experience initiated by Pentecostal churches in the homeland'.

In my study, I examine the ways these spaces are structured by religious leaders and how these leaders interpret migratory processes religiously, transforming them into meaningful church experiences for churchgoers. My data shows how pastors reorganize religious space to negotiate moral and cultural identities that either help foster integration of migrants into new social roles or duplicate the communal experiences of a constructed homeland while adapting these practices to new surrounding circumstances.

\section{A Social Architecture: Missions, Fellowships, and Roles}

Every Friday, the intercessors come together to intercede for the church. They intercede for our people, we intercede even for the Basque Country, and we intercede for Spain. So, we pray all around. We pray for the city, we pray for the state, we pray for the mission. We have another group here called the women's group. At the women's group, my wife is the one who is taking care of them. So, she pulls them together on how women need to behave in the church and in their homes and even in society. We also have men's groups and they also have responsibility for how to behave in the church and in their homes and in society. We have the youth, the singles who are not married, so they also have a meeting. In their meetings, one of these days, I saw the way they organize themselves on how to behave in society and behave in the church so there will be no violence. We also have a children's group. We teach them about Christianity and how to read what they learned in school, how to read the Bible and study the Bible. How to respect their father and their mother; because most of the children in the society today, especially the Spanish children, they don't know how to respect. We have to teach our children how to respect their parents.

Apostle David, Nigerian, in Bilbao, Spain, 2014

Apostle David, founder of the Hand of God Ministries International, preaches in Bilbao together with his wife, Pastor Irene, and Edward, an assistant or resident pastor, in a congregation mainly attended by Nigerians and other West African nationals. The three pastors have been living in Bilbao for over a decade and their long-term residence in the country has granted legal documentation to carry on their activities. Before residing in Spain, they lived in multiple countries either in Europe or Africa and had formal education ranging from technical courses to university degrees. Their "privileged" situation contrasts with most churchgoers who attend their congregation. As pastor Edward explained to me, their followers are often undocumented migrants with low levels of education. Located in a semi-peripheral neighbourhood ${ }^{5} 10$ blocks away from high-end shops, street cafes and tourist buildings, the church building is reminiscent of the industrial era that lifted the Spanish economy in the first half of the 20th century. The denomination has other branches in David's hometown of Benin City, Nigeria, as well as in the Spanish cities of Valencia and Pamplona. From 2006 to 2016, I witnessed the expansion of the church's headquarters in Bilbao in both space and the number of attendants, currently at around 150 .

The profile of churchgoers is mixed: children, young people and adults who seem to attend services with their nuclear families. The congregation has a variety of activities for members, ranging from weekend entertainment and spiritual guidance to weddings, baptisms, fellowships, prayer groups

5 Considering the dimensions of the municipality of Bilbao (350,000 inhabitants), its population density is one of the highest in Europe $\left(8300 / \mathrm{km}^{2}\right)$. The metropolitan area extends to around $15 \mathrm{~km}$, and along the margins of the River Nervión, there are churches located in a strategic area that is relatively close to the city centre ("Chart 158 ". Ine.es. Archived from the original on 3 April 2015. Retrieved on 26 June 2014.) 
and choirs. This diversity establishes subdivisions, commonly known as fellowships, which provide specialized devotional practices. This is a widespread strategy among Pentecostals. Such encounters help socialize each member to either a gendered or age-specific form of spiritual worship; they may also encourage the development of particular charismatic or musical skills. After a year of visiting Apostle David's church, I realized that the importance these religious activities hold goes beyond the weekly Sunday service. The many activities offered are a means for socialization worshippers into both the African Pentecostal tradition and into Spanish society. I observed this patter in other congregations as well.

Pentecostal church leaders understand these activities as forms of teaching or training for migrant churchgoers. Members are taught how to respond to the stresses of their host society and to their interactions with other migrants and locals. As David explained, these meetings address pressing social topics, experiences and circumstances, while detailing specific virtues for each group: they teach men responsibility, children respect for their parents, and young people about calmness and peacefulness (so as to avoid violence). Pastors and worshippers discuss reactions to xenophobic attacks, tackle unemployment by promoting informal jobs within the community, and address gender, conjugal, and peer conflicts.

I also visited Diplomat's Assembly, a Nigerian-led Pentecostal church in the semi-peripheral vicinities of the Randburg in greater Johannesburg. The building, which was typical of an industrial area, was an unsurprising location for a Pentecostal church as far as I observed in my fieldwork in Bilbao and Johannesburg. The congregation was founded by Pastor Emmanuel and assisted by Pastor Victor, whose activities include preaching in radio shows and online streaming videos. Three other branches of the church had developed activities under this particular denomination: two in Port Harcourt and Lagos, Nigeria, and one in Nairobi, Kenya. Pastor Victor articulated that the vision of the church is strongly marked by educating congregants not only in spiritual matters, but also in several aspects of social life ranging from affective relationships to finances.

With these brief accounts of Pastor Emmanuel's church in Johannesburg and Apostle David's church in Bilbao, I drew a preliminary picture of what I later observed in all six congregations selected for this fieldwork. As trained pastors, migrants themselves, and holders of charismatic skills, these church leaders design sections and subdivisions among worshippers that shape a hybrid African and Pentecostal culture. Their social architecture allows strategic spaces for the negotiation of cultural tensions and for the establishment of moral codes and modes of behaviour that configure African Pentecostal responses to modernity. In other words, while (re)producing this social architecture, pastors and worshippers are also creating (and belonging to) a borderless kingdom of God.

As I intend to show, the integration of worshippers into such social architecture is accomplished first by the breakdown of the church community into smaller assemblies. These smaller groups provide a specialized social capital for worshippers as they are taught the African Pentecostal values they need to navigate the vicissitudes of life in their host countries: Spain and South Africa. Second, each group engages members in a spiritual transformation process that prepares them to assume family roles as mothers, fathers, children, men, women, elders, religious roles as evangelists, missionaries, pastors, and professional positions as teachers, medical doctors, businessmen or women, etc. A third dimension of this process involves the ascription of meaning to interpersonal relationships among group members. This forging of family-like bonds and the creation of a moral community seems to bring together members of different ethnic groups and educational backgrounds through shared biographical experiences. As they reach across social boundaries, members exchange stories of everyday experiences and suggest to each other solutions to the problems that their lives as migrants raise. These mutually supportive relationships produce a shared sense of belonging to a simultaneously inclusive and exclusive religious community.

In sum, the following sections explore the ways through which such communities rework cultural elements from either South Africa or Spain into African and European traits within a Pentecostal framework. This approach offers a particular model for reality that conflates the various models of 
reality-local, global, conservative, progressive, Spaniard, South African-particularly evident in diasporic contexts (cf. Geertz 1966). It is one that helps them to repurpose their lives and make sense of relationships inside and outside the church community in Bilbao or Johannesburg; it also helps them make sense of their mission of spiritual transformation within the church.

\section{Forging Afro-Christianities}

In both Bilbao and Johannesburg, church fellowships were similarly organized by gender, age and individual spiritual gifts. Assistant or trainee pastors and other leading figures (i.e., fellowship leaders, prayer leaders, etc.) were often held responsible for organizing the activities where age and gender were identified by church leaders as the most important demographic features for spiritual and social growth. Some distinctive skills acquired or offered by worshippers indicate their integration into respective groups. Ushers, for example, organize services. Spiritual practices such as prayer and music become important services that members cultivate as they are socialized, integrated, and made to feel to belong to the group.

Pastor Ehis, a Nigerian church leader interviewed in Bilbao, runs the Christ the Rock Ministries, a Pentecostal church in the area of Errekalde. The congregation hosts around 120 people, mostly Nigerians and English speakers. He explained to me the purposes of gender- and age-related fellowships in his church:

The men's fellowship is for letting them know how to live as a married man. When you are married, there are principles you need to follow. The principles of Christ you need to follow. The organization of women is to teach them how to live as a married woman. What they need to do and the responsibility as a Christian married woman. The youth, you teach them what to do as a youth and the life they need to live, the kind of lifestyle you need to live as a Christian. That's why these groups are organized; for them to know their part to play as a Christian.

Pastor Ehis, Bilbao, Spain 2014

In addition to these fellowships, Pastor Ehis also underlined the importance of the elders' group, whose function are similar to the African cultural tradition of leaders who represent and discuss matters on behalf of the larger community. These elders are respected members of the African Pentecostal congregation and are not simply lay worshippers in the way an adult woman or young boy might be. They are defined as wise worshippers, and they often preach in specific services and church gatherings.

In this way, these subgroups not only uphold key Christian roles, but they also respect and uphold social values and moral codes rooted in what they understand and honour as part of African culture. Addressing how to carry out proper affective relationships, cope with family conflict, or build loyalty and honesty in friendships were among the most pressing concerns for church leaders and attendees. These topics were discussed regularly in the various fellowship groups, with constant references made to the Bible. These references help believers cultivate a shared understanding of personal conflicts that can be anticipated or even solved by spiritual means.

Moreover, belonging to a religious community requires compromise: not only in terms of worship practices, but in the formation of affinity groups. Such affinities have been previously defined by the organizational structure of the church (e.g., prayer warriors, choir members, fellowships, etc.) and are often recalled and deployed in collective gatherings of all sorts (e.g., intradenominational or interdenominational church services, festivals, conferences, etc.). These affinity groups can also refer to migratory categories. For instance, when located in Bilbao, values and morals are articulated under the auspices of stereotyped European and African ontologies. At times, pastors stressed what it means to be a 'real African man', or they address the community as 'we, Africans' as opposed to 'those Europeans'. In Johannesburg, the basis for comparison to an 'other' was linked to secularized 
South African society as opposed to its more traditional counterparts. Instead, the wider society ${ }^{6}$ was broadly framed as violent, xenophobic, inefficient, and materialistic, as opposed to more positive attributes that aspire toward cultivating a strong work ethic or the pursuit of promising educational and business opportunities.

The small-group structure increases the number of opportunities for migrants to develop a sense of belonging among those who share similar struggles and for whom experiences of migration resonate. This social architecture of belonging is shared not only within the community of reference, but also among those in other African congregations. It is not uncommon, for instance, to participate in conferences dedicated to fellowships within a particular church network or denomination. Likewise, a believer can participate in a fellowship that is not part of a specific congregation but constitutes an independent ministry.

For example, Pastor Emmanuel, now a media personality and senior pastor at the Diplomat's Assembly Church, told me that he was gradually introduced to the world of preaching when attending a university student fellowship in Nigeria, his home country. He said: 'we got into the fellowships and we got to know so many things that we didn't know had become exposed to Pentecostal preachers; and then, the more we knew, the more our mind opened up, and the more I've found myself preaching more, talking to more people.'

While the pastor complained that, back then, he did not feel socially integrated in the university environment, the fellowship opened a new way for him to socialize with other students in non-academic settings. Furthermore, Emmanuel's student fellowship at university was constantly visited by pastors from different congregations who were experienced in caring for student fellowships at other universities throughout Nigeria and abroad. The relationship Emmanuel established with this network of pastors helped him set up his own church in South Africa later on in his life.

These scenarios echo what Loren Landau (Landau 2009) has previously highlighted as the capacity of religion to bind communities in a 'stable way', offering channels of inclusion and mechanisms of exclusion. Moreover, when dealing with unbelievers or new believers, religion has the ability to enhance cohesion and resistance. Landau's work points out that religious organizations are capable of bonding host and migrant communities, as well as offer fertile ground on which to preserve 'a touch of the familiar amidst an identifiable other' (Landau 2009, p. 5).

The kinds of diversities observed in the churches of Bilbao and Johannesburg also parallel what Steven Vertevoc calls 'super-diversity' or 'the proliferation and mutually conditioning effects of additional variables' (Vertovec 2007, p. 2). He shows that diversity cannot be seen solely through ethnic or linguistic lenses. Additional variables were observed in this case by pastors who expressed their difficulty in dealing with the different levels of spirituality and faith among worshippers. According to them, such 'imbalances' are due to the cultural, social, educational, migratory, generational, and linguistic differences among congregants, which explains the strong agenda for Afro-Christian socialization. According to Kando, founding pastor of the Misión Evangélica de la Reconciliación, a diverse set of individual variables and personal traits need to be examined at a micro-level and spiritually managed by pastors in order for congregants to 'sing the same tune'. In spite of its unusual location-an underground storage facility of a derelict building in a migrant area of Ibaiondo in Bilbao-the church carries on a series of weekly activities. These activities give worshippers the chance to collectively develop their spiritual gifts such as singing in a choir, praying or studying the Bible.

Therefore, the process of the 'layered integration' of worshipers within the church community forges stable bonds among equals without stressing ethnicity or nationality. This spiritual integration within the fellowships helps congregants-whether immigrants or locals-socially define themselves.

6 I define 'wider society' as including the Basques, South Africans, non-congregants, or other migrant groups. However, it is acknowledged that a 'wider society' is not a unified construct by which social and cultural recognition among its members is monolithic. For our purposes, the notions of 'host' or 'wider' societies are discursive efforts to frame 'otherness' along the social construction of 'us'. 
The breakdown of the church into specialized fellowships also helps forge roles that seem consistent with African Christian values, regardless of where worshippers reside. Adscription to fellowships helps pastors manage the social and cultural diversity of their congregations, but that in itself is not enough. It also enables re-signification of kinship and social bonds among migrant worshippers.

\section{The Negotiation of Gender and Family Roles}

Understanding the forms of belonging among African Pentecostals depends on the pastors' approaches to managing a congregant's socialization and integration to the larger group, encouraging members to 'stick together' no matter where they reside. Moreover, the emotional attachments among congregants fostered by Pentecostal pastors in Bilbao and Johannesburg are evoked through co-dependent processes of individualization and communitarization of certain values, roles, and ideas. But how does this type of 'bridging' operate? Which aspects are recalled and deployed in such a process? How are African Pentecostal migrants' ideals of family and gender roles different from their European and non-Christian ideals and how do these church leaders and communities navigate these differences?

Participation in the weekly activities and everyday life of these churches' circles exposes migrants to a constant call for the resuscitation of 'lost' family values and for the maintenance of an ontological security found only in the kinship that characterizes the 'kingdom of God'. The relationships among worshippers under the aegis of a 'new family' are developed, where kinship and social bonds are rearranged by harmonious discourses of control and stability. This ideal family encapsulates biological nuclear notions while being extended to spiritual brothers, sisters, 'papas', and 'mammas', as they are affectionately called among African Pentecostal Christian communities.

On closer examination, it is clear that something akin to a renegotiation of gender roles takes place at the intersection of Christian and African(ized) kinship. Beyond their attained religious titles, church leaders are often referred to as the spiritual papa or mamma of the community, while worshippers refer to themselves as brothers and sisters in Christ. Age, marriage, maternity, and paternity are then reflected at the spiritual level in order to recall the pillars of a Christian congregation. Maturity is defined as a form of spiritual knowledge acquired as a consequence of one's marital status (e.g., single or married, a father or a wife). The reiterated stress upon marriage and parenthood indicates that the combination of spiritual knowledge and family-driven maturity is a prerequisite for leadership. In the words of Pastor Adam, resident pastor at the Hand of God Ministries International in Bilbao, one's marital status and attainments are the 'passport for righteousness'.

In my case-studies, the pastors' discourse views the surrounding dominant contemporary secular social realm as problematic. This stems both from the perceived lack of Christian beliefs and from the mistakes that emanate from modernity. Preachers in Johannesburg and Bilbao saw the maintenance of the patriarchal family as inherited behaviour; such filial values were characterized as being culturally African, varying a bit by specific countries of origin. Indeed, Nigeria and the Democratic Republic of Congo (DRC) were characterized as 'more Christian' compared to South African or Spanish society, but they were also 'more African', or 'more modern', depending on the issues being compared.

In Bilbao, pastors depicted Spaniards and Europeans as too modern and thereby as un-Christian or immoral. They also warned worshippers about African fellows who arrived in Europe and forgot God in their detrimental pursuit of materialism and individualism. In Johannesburg, pastors' critiques were twofold: on the one hand, they aimed at the un-Christian nature of South African traditions by relating them to witchcraft, sorcery, and magical beliefs. These were seen as 'old Africa', whereas African Pentecostals from Nigeria and DRC were championing the new Africa. On the other hand, they pointed to the richness of the South African economy as the 'evil' that had brought materialism and ungodly, un-African modern behaviours: drugs, divorce, violence, etc. From my perspective, these ambiguous responses display a tactical positionality regarding gender and family roles in which Pentecostals seem to always hold the 'right formula' for solving societal problems. 
On several occasions, migrant pastors referred to the challenges that families face when learning to conform to standards of Pentecostal worship in everyday life. While divorce and the 'modern' devotion to a single life were both considered negative among Pentecostal leaders within their respective societies, women were often portrayed as both the protagonists and the victims of such contexts. At a women's conference at the Bread of Life Foundation, in Johannesburg, male and female pastors presented a series of Biblical anecdotes as reasons why women need specific attention in prayers. Papa Shaun, an experienced pastor and founder of the church, used the acronym W.O.M.A.N. to describe the characteristics and roles women play spiritually: ' $\mathrm{W}$ ' is for wise, ' $\mathrm{O}$ ' is for organizer, ' $\mathrm{M}$ ' is for manager, ' $\mathrm{A}$ ' is for adviser and ' $\mathrm{N}$ ' is for nurse. Papa Shaun used various Biblical verses to support and scrutinize each of these word concepts and constructed a short theological narrative about women's societal duties in the family. He eulogized the 'natural' aspect of purity and 'cleanness' present in femininity. Some invited speakers from other churches also presented their insights on the subject.

One particular point was emphasized by a female pastor, who stated that 'women are the mystery of God'. She explained that women are mysterious by nature due to the prominent role played by emotions in the constitution of the feminine character. According to the pastor, this gendered characteristic contrasts with the male persona that is generally more rational. In this way, mystery and rationality were used as tools for enacting or mediating changes and awareness about what the female pastor considered as women's 'natural weakness': emotions. This idea was followed by the association of women with snakes, symbols of evil and temptation. The conference promised to empower women to fight against their weaknesses, which manifested themselves in such acts as defying male authority, materialism, divorce, abandoning children, or not getting married. This narrative caught my attention, as I had heard similar parallels between womanhood and 'mystery' in several church services, both in Bilbao and Johannesburg.

In both the African and the European contexts, pastors viewed the empowerment of women in the private sphere as her capacity to deal with family issues while maintaining a woman's role as a wife and mother. At times, pastors contrasted this vision with the 'local' way of performing these roles. Spaniards and South Africans were often deemed to be un-African and to be leading un-Christian lifestyles; these resulted in the bad behaviour of children, in homosexuality, and in the failure of both women and men to marry or remain married. By contrast the key contribution of Christian women in society was to be nurturing and to provide love and care to an otherwise broken environment. Alternatively, other pastors stated that they were concerned with women's roles becoming increasingly materialistic. They feared that financial desperation might tempt women to drift into prostitution or into relationships without love.

Yet, love was the feeling that was mostly referred to as being beyond gender. Love was also expressed in pictures as images of union between a man and woman in love. Flyers and posters were distributed in the neighborhoods around the churches, portraying the pastor and his or her partner as the protagonists of the church service see (Cazarin 2017). Such images pictured women as holding together the family by supporting their children, keeping a harmonious marriage, and keeping a functional household. These 'tasks' were seen as a part of the mission to be accomplished by every Christian woman who belongs, or aims to belong, to the kingdom of God. This mission is not just for themselves, it also seeks to convert the 'lost ones' (South Africans, Spaniards, and other African migrants) to these roles, as this would re-integrate them into God's Kingdom.

Likewise, men were also given a clear picture of what model to follow, especially with regards to those who serve in the church. All male pastors interviewed were married, and all had at least one child. Sermons in both Spain and South Africa repeatedly expressed the idea that being a true 'man of God' is connected to having a wife and being a father. In fact, more than age and attainment, in these congregations, parenthood and marriage were seen as important features of one's vocation. Although all the pastors were roughly between thirty and fifty years old, no mentions of age were made when questioned about the requirements for being a leader. In this way, the status and power of a pastor seemed to be also related to one's role in family life, particularly, if they had-or not—'become 
a man'. Here, the notion of manhood was linked with the archetype of an '(Christian) African man' who becomes real once he has a wife and children.

Inspired by a kinship found in God, African pastors symbolically legitimized social boundaries and the collective imagination of filial piety by teaching congregants to reject the past and to adopt a new family with intrinsic Afro-Christian morals. In this imagination, the church rises up as a symbol of one harmonious 'family' that surpasses all others. It adopts defensive strategies to protect the church from the evils of modernity that threaten its sacred bonds. By addressing the common failures and successes of married life among church members, pastors use their own conjugal experiences to craft moral lessons and sacred formulas to help congregants cope with the emotional stresses of a migrant's private daily life. This spiritual kinship, discursively founded upon concepts of harmony and love, is extended to those who remain faithful to the church as devoted and actively engaged Pentecostals, no matter where they reside.

\section{Restoring 'Broken' Societies into the Kingdom of God}

The idea of socially and morally repairing the society that surrounds the church starts within the church community itself, as well as with every single worshipper. In other words, a pastor's discourse must reflect the mission of bringing the kingdom of God to the world system, where tangible objectives are primarily focused on intimate and familiar domains. Particularly in the African diaspora, dynamics regarding migratory processes become a primary concern for African Pentecostal churches. There first arises a cry from the heart for a forgotten (essentialized African) communality and Christian ethos.

Pastors see it as their duty to show congregants that Christian values will alleviate the psychosocial dissonances between migrants' religio-culture and the stresses of wider society-in this case South Africa or Spain. Secondly, the church attributes distinct value to social bonds within the congregation, reinforcing its collective self-esteem to the detriment of the undesirable characteristics of other groups.

The cry for the restoration of a lost African and Christian ethos requires the transposition of an African communality to the everyday spiritual life of its members (Adogame 2004; Waweru 2011; Sow et al. 1977). According to Dimitri Bondarenko, the idea of communality 'is wider than community in the sense that as a principle of social life organization and a basis of culture, it can well manifest itself in complex societies, far beyond the community' (Bondarenko 2008, p. 7). Communality serves as a true matrix for building a complex society with pillars that enable reconstruction.

The transmission of communality within and beyond the borders of these congregations is twofold: it restores those who are both 'close' and 'far' from their respective congregations. A 'mission', as defined by several pastors, implies that this African communality is aligned with a Christian ethos that creates a 'this-worldly' simulacrum of the kingdom of God. In other words, it is the 'spiritual education' or 'maturity' of the congregation within an African Pentecostal framework that makes sense of group dissonances and challenges the wider society restores itself and becomes a spiritually driven social order. This idea reimages a once marginalized immigrant minority into a group that possesses the 'right' formulas for dealing with the distresses of the present world.

This reconstruction of bonds, morals, and values is focused on a modernized religious 'project' to 'fix' and restore a broken society. The pastors articulated these goals in cosmopolitan discourses, emphasising the strengths of both their host societies and their societies of origin, while recalling what they had learned throughout their migratory processes. Examples of this perspective were exhibited by Pastor Irene, who re-appropriated the term 'civilization' to explain how she was able to make spiritual sense of her experiences in Africa and Europe:

Yes, there are some differences. When I went to Africa, I went to preach in our church and I also told them things that are good here, which they have to apply. Anywhere we are in the world, we must see something good in the place where you might not have that good thing. Maybe you are not seeing anything good, but there are things and you can pick them. Do you know the civilization? You go and pick those good things and add it to your own 
and you will become richer than before. So, I also took things from here [Bilbao] that are good and told them.

Prophetess Irene, Bilbao, 2015

In my view, the civilization evoked by Irene is neither African nor European; it involves an understanding of Christian morality entrenched in the Bible that absorbs both African(ized) and European(ized) values. All of these work together to help 'restore' a society to which migrant African Pentecostals can easily relate. By constructing a mental prototype that conflates being African, being migrant, and being Pentecostal, these pastors reconstruct common categories of masculinity, motherhood, European, African, religion, tradition, and culture. In doing so, their churches become a 'producer of institutional power (by) skilfully using globalization to create a global religious empire' (Knibbe 2009, p. 156). Such dynamics also echo the processes of boundary maintenance (Barth 1969) and 'ethnicization' (Sarna 1978), by which solidarity and cohesion are developed within a group and delineate a transnational Pentecostal culture.

\section{Conclusions}

Findings from my study reveal an African Pentecostal social architecture that forges spaces of belonging for worshippers in diasporic contexts. Three strategies guide this process: (1) the division of the larger church community into smaller fellowships aimed at providing socially transformative missions to worshippers and pastors; (2) the (re)configuration of migrants' African and Pentecostal values to bring about purposeful roles within the church community and wider society; and (3) the creation of family-like bonds and morality-based relationships in the congregation to reshape worshippers' ethnic diversity into an African and Pentecostal melting-pot centred on the moral restoration of 'broken' societies.

This social architecture not only demonstrates how socialization processes of belonging mediate such religious institutional apparatuses, but also demonstrates the complexities of integrating migrants into both the Pentecostal Charismatic community and into their wider secular societies. From weekly Sunday encounters, fellowships, or Bible schools to the establishment of relationships with migrants from other congregations, these interstitial spaces expand and grow to become a network of reference. The development of religious links and organisational structures does not rely exclusively on functional demand; the lived experiences of diverse congregants in multiple localities are significant too. While church services, conferences, and fellowships are happening in emptied warehouses, office spaces, or living rooms, these spiritual encounters are only sustainable across time if individuals feel purposefully connected with their changing life experiences.

As Homi K. Bhabha notes, within interstitial spaces marked by diversity, 'the exchange of values, meanings and priorities may not always be collaborative and dialogical but profoundly antagonistic, conflictual and even incommensurable' (Bhabha 1998, p. 6). In order to alleviate societal dissonances, African Pentecostals through their sermons, prayers, songs, and testimonies reinterpret, relocate, and seek to negotiate and resolve those problems by directing worshippers into specialized fellowship groups, each with distinctive roles stratified by age, gender, and/or marital status.

As stated by the church leaders I interviewed, the novelty of the African Pentecostal movement is not necessarily based on juxtaposing the ways the church of origin was built and inventing completely different strategies for a new church. Rather, African Pentecostal congregations succeed on a transnational scale precisely because they provide a social architecture of African Pentecostal morality. In a process of layered integration, this morality bounds these communities together in shared values ascribed to their respective gender, age, or spiritually gifted roles.

Whether in Johannesburg or Bilbao, the social architecture of belonging created in these African Pentecostal churches is not strictly tied to geographic boundaries. It is, instead, composed of religious experiences that integrate believers into a specific congregation and worldview. Such experiences may (1) deconstruct particular notions of integration through Pentecostalism, as well as (2) offer spaces 
for belonging into collective, and individual, transformative projects within a diasporic network. As argued above, this social architecture is a platform for worshippers to shift and lift their social status from the margins to the centre while bridging the past and present, tradition and modernity, the individual and the communal, and their origins and destinations.

Funding: This research was funded by the Government of the Basque Country-Eusko Jaurlaritza, grant "Formación y Perfeccionamiento de Personal Investigador (2011-2015) No Ref BF-2011-263 Modalidad AE", also with the support of ISOR Research in Sociology of Religion, Autonomous University of Barcelona.

Acknowledgments: I am grateful to Anna Halafoff (Deakin University), Jim Spickard (University of Redlands) and Denise Lim (Yale University) for their assistance and valuable insights to the content and format of this article which improved the manuscript significantly.

Conflicts of Interest: The author declares no conflict of interest.

\section{References}

Adogame, Afe. 2004. Contesting the Ambivalences of Modernity in a Global Context: The Redeemed Christian Church of God, North America. Studies in World Christianity 10: 25-48. [CrossRef]

Akyeampong, Emmanuel. 2000. Africans in the Diaspora: The Diaspora and Africa. African Affairs 99: 183-215. [CrossRef]

Anderson, Benedict. 1991. Imagined Communities, Reflections on The Origin and Spread of Nationalism. London: Verso Press. Anzaldua, Gloria. 1987. Borderlands/La Frontera: The New Mestiza. San Francisco: Spinsters/Aunt Lute.

Ayuntamiento de Bilbao. 2017. Inmigración Extranjera en Bilbao. Available online: http://bit.ly/2ZieWfP (accessed on 26 June 2018).

Barth, Fredrik. 1969. Ethnic Groups and Boundaries: The Social Organization of Culture Difference. Boston: Scandinavian University Books. Little, Brown. Available online: http://books.google.es/books?id=E9HtAAAAMAAJ (accessed on 16 April 2015).

Bhabha, Homi. 1998. O Local Da Cultura, 2nd ed. Belo Horizonte: Editora UFMG.

Bondarenko, Dmitri. 2008. Kinship, Territoriality and the Early State Lower Limit. Social Evolution and History 7: 19-53.

Brighenti, Andrea Mubi. 2013. Urban Interstices: The Aesthetics and the Politics of the In-Between. Farnham: Ashgate Publishing Limited. Available online: https://books.google.es/books?id=91GiAgAAQBAJ (accessed on 2 June 2015).

Cazarin, Rafael. 2017. African Pastors and the Religious (Re)production of a Visual Culture. Special Issue: Etnográfica 20 Years Anniversary 21. Available online: https://journals.openedition.org/etnografica/4980? lang=es (accessed on 15 May 2019).

Clifford, James. 1997. Diasporas. In The Ethnicity Reader: Nationalism, Multiculturalism and Migration. Edited by Monstserrat Guibernau and John Rex. Oxford: Polity Press.

Coleman, Simon. 2000. Globalisation of Charismatic Christianity: Spreading the Gospel of Prosperity. New York: Cambridge University Press.

Curl, James Stevens, and Susan Wilson. 2015. The Oxford Dictionary of Architecture. Oxford Paperback Reference. Oxford: Oxford University Press. Available online: https://books.google.co.za/books?id=4Lu6BwAAQBAJ (accessed on 15 March 2019).

Fernandez, James W. 1978. African Religious Movements. Annual Review of Anthropology 7: 195-234. [CrossRef]

Gaiya, Musa. 2002. The Pentecostal Revolution in Nigeria. In Occasional Papers. Copenhagen: Centre of African Studies, University of Copenhagen.

Geertz, Clifford. 1966. Religion as a Cultural System. In Anthropological Approaches to the Study of Religion. Edited by Michael Banton. London: Tavistock, pp. 1-46.

Gerloff, Roswith. 1995. The Holy Spirit and the African Diaspora. Bulletin XIV: 85-100.

Gupta, Akhil, and James Ferguson. 1992. Beyond "Culture": Space, Identity, and the Politics of Difference. Cultural Anthropology 7: 6-23. [CrossRef]

Hage, Ghassan. 2005. A Not so Multi-Sited Ethnography of a Not so Imagined Community. Anthropological Theory 5: 463-75. [CrossRef] 
Hepburn, Eve, and Ricard Zapata-Barrero. 2014. The Politics of Immigration in Multi-Level States: Governance and Political Parties. Palgrave Politics of Identity and Citizenship Series. Basingstoke: Palgrave Macmillan. Available online: https://books.google.es/books?id=WzDtAwAAQBAJ (accessed on 10 June 2015).

Hollenweger, Walter. 2004. An Introduction to Pentecostalisms. Journal of Beliefs \& Values 25: 125-37.

Houle, René, and Comunicació Presentada al II Seminari. 2000. Integration of Migrants and Refugees in Local Communities: Problems and Policies. Moscú: Web del CED (Centre d'estudis demogrÓfics), pp. 1-25.

Hunt, Stephen. 2002. 'Neither Here nor There': The Construction of Identities and Boundary Maintenance of West African Pentecostals. Sociology 36: 147-69. [CrossRef]

Jesse, Fungwa Kipimo. 2014. Studying Pentecostalism Missiologically: The Congo Evangelistic Mission in Katanga Province, Democratic Republic of Congo. Pretoria: University of South Africa. Available online: http: //uir.unisa.ac.za/bitstream/handle/10500/18320/thesis_jesse_fk.pdf (accessed on 18 June 2015).

Kalu, Ogbu. 2008. African Pentecostalism: An Introduction. New York: Oxford University Press.

Kalu, Ogbu. 2009. A Discursive Interpretation of African Pentecostalism. Fides et Historia 41: 71

Knibbe, Kim. 2009. 'We Did Not Come Here as Tenants, but as Landlords': Nigerian Pentecostals and the Power of Maps. African Diaspora 2: 133-58. [CrossRef]

Koenig, Matthias. 2005. Incorporating Muslim Migrants in Western Nation States-A Comparison of the United Kingdom, France, and Germany. Journal of International Migration and Integration 6: 219-34. [CrossRef]

Landau, Loren. 2009. Living Within and Beyond Johannesburg: Exclusion, Religion, and Emerging Forms of Being. African Studies 68: 197-214. [CrossRef]

Levitt, Peggy. 2007. Redefining the Boundaries of Belonging. The Transnationalization of Religious Life. In Everyday Religion; Observing Modern Religious Lives. Oxford: Oxford Press.

Levitt, Peggy, and Nina Glick Schiller. 2004. Conceptualizing Simultaneity: A Transnational Social Field Perspective on Society. International Migration Review 38: 1002-39. [CrossRef]

Marshall, Ruth. 1998. Mediating the Global and Local in Nigerian Pentecostalism. Journal of Religion in Africa 28: 278. [CrossRef]

Ndung'u, Nahashon. 2009. Persistence of Features of Traditional Healing in the Churches in Africa: The Case of the Akurinu Churches in Kenya. Thought and Practice 1: 87-104. [CrossRef]

Pew Forum on Religion \& Public Life. 2006. Spirit and Power: A 10-Country Survey of Pentecostals. Washington, DC: Pew Research Center.

Pew Forum on Religion \& Public Life. 2012. Faith on the Move: The Religious Affiliation of International Migrants. Available online: https://pewrsr.ch/2KItcun (accessed on 15 March 2019).

Pinnock, Clark. 2000. Divine Relationality: A Pentecostal Contribution to the Doctrine of God. Journal of Pentecostal Theology 8: 3-26. [CrossRef]

Sanneh, Lamin. 1989. Translating the Message: The Missionary Impact on Culture. American Society of Missiology Series. Maryknoll: Orbis Books. Available online: https://books.google.co.za/books?id=cUbZAAAAMAAJ (accessed on 24 April 2015).

Sarna, Jonathan. 1978. From Migration to Ethnics. Ethnicity 5: 370-78.

Skeldon, Ronald. 2014. Migration and Development: A Global Perspective. Longman Development Studies. New York and London: Routledge. Available online: https://books.google.es/books?id=og-PBAAAQBAJ (accessed on 12 July 2015).

Sow, Alpha, Ola Balogum, Honorat Aguessy, and Pathe Diagne. 1977. Introduction a La Culture Africaine. Aspects Generaux. Paris: Unesco.

Vertovec, Steven. 2007. Super-Diversity and Its Implications. Ethnic and Racial Studies 30: 1024-54. [CrossRef]

Währisch-Oblau, Claudia. 2009. The Missionary Self-Perception of Pentecostal/Charismatic Church Leaders from the Global South in Europe. Bringing Back the Gospel. Leiden: Brill Academic Publishers.

Waweru, Humpfrey. 2011. The Bible and Culture, Mapping Transactional in Roads. Eldoret: Zapf Chancery.

Wilkinson, Michael. 2011. Canadian Pentecostal Diversity: Incorporating the Many Voices. Canadian Journal of Pentecostal-Charismatic Christianity 2: 41-82.

(C) 2019 by the author. Licensee MDPI, Basel, Switzerland. This article is an open access article distributed under the terms and conditions of the Creative Commons Attribution (CC BY) license (http://creativecommons.org/licenses/by/4.0/). 

Article

\title{
From 'Islamism' to 'Spiritualism'? The Individualization of 'Religion' in Contemporary Iran
}

\author{
Hossein Godazgar \\ Department of Sociology, University of Warwick, Coventry CV4 7AL, UK; h.godazgar.1@warwick.ac.uk
}

Received: 4 November 2019; Accepted: 31 December 2019; Published: 7 January 2020

\begin{abstract}
In the first four centuries of Islam in Iran, mosques were arguably the only sacred places for Iranian Muslims to pray. It was only after the invasion of the Mongolians and the resulting expansion of Shi'ism and Sufism throughout the country that the tombs of some sacred figures, including Imams' grandchildren ('Imamzadehs') or ('Maqbarahs'), became shrines and important sites for pilgrims. It is interesting that pilgrimage to both Imams' shrines and Imamzadehs and their associated expressions and perceptions lie at the center of the Shi'ite experience of 'religion', although they are rarely mentioned in the relevant core sources of Shi'ism. Nevertheless, to borrow a Weberian image, during the Islamic revolution of 1979, mosques became the 'vehicles' for the religio-political ideology of the revolution. Unlike Imamzadehs, they embraced dissidents from a variety of social classes, ranging from emigrants from rural areas to educated liberals and intellectuals. In the fortieth anniversary of the revolution, the findings of my three-year research project illustrates that whilst the religious status of mosques is decreasing, Imamzadehs as well as other venues detached from Islamic authority and political Islam are increasingly becoming 'vehicles' for ideas and sentiments for the expression of more individualistic and 'spiritual' sensations, rather than the manifestation of an established and institutionalized religio-political ideology. Taking inspiration from a social constructionist approach, discourse and content analysis of media, participant observation in 'Shi'ite' venues situated in three provinces, particularly three Imamzadehs or Maqbarahs, and thirty semi-structured interviews in north-west Iran, this article aims to report the findings of this project by focusing on the meanings of 'religion' (and 'non-religion') and 'spiritual' (and 'non-spiritual') attached to these venues, including Imamzadehs, and their material culture as well as the changes our informants have experienced in this regard through time and space, particularly during the last forty years.
\end{abstract}

Keywords: social constructionism; religion; Islamism; Islam; Shi'ism; spiritualism; rituals; Iran

'Inspired by this fundamental thought [the great significance of mosques in early Islam], with the emphasis of the Leader of the revolution [Ayatollah Khomeini], the Iranian Muslim nation turned mosques back to their fully mobile and vital status as in early Islam during the current of the Islamic revolution, particularly one year before and after the triumph of the revolution. And [using mosques] the combatant [revolutionary] clergy explained the political thought of Islam, disseminated the movement's goals and disclosed the [pre-revolutionary] regime's catastrophes, the sinister effects of foreign domination and the global imperialist plots, especially that of the United States and Zionism, in the trench of altar and pulpit... In summary, mosques changed to forceful centers for the support of the revolution and the operation headquarters of the Leader of the Islamic Revolution at that time. And the Islamic Republic of Iran was born in mosques ... Against the danger of the separation of the revolution from mosques, which was the Islamic revolution's new plot, Imam Khomeini (pbuh) said: "Don't be scared of the enemy's [military] jets; be scared of [the day when] mosques become empty."

[Imam Khomeini, Sahifeh-i Imam, vol. 3, p. 21]

This is a quotation from Ayatollah Abbas-Ali Amid-Zanjani (Amid-Zanjani 2012, pp. 41-42), who was one of Ayatollah Khomeini's students and an influential figure in the powerful Combatant Clergy 
Association (jame'eh-ye rouhaniyat-e mobarez), describing mosques as 'the most important centers for bringing about the revolution' (Amid-Zanjani 2012, p. 40). No scholar of the modern history of Iran would perhaps argue against the critical role that mosques and traditional seminaries played beside the secular political forces during the Iranian revolution of 1977-1979; one that is even referred to as a 'mosque-based' revolution (Halliday 1999, p. 50). In this article, I argue that the mosques have become 'empty' in the fourth decade of the Islamic Republic, despite the wish of its founders and contemporary authorities. The obvious question is: 'Where have the congregations gone?' or 'What has happened to their 'religiosity'? This article is an attempt to answer these questions, aiming to identify and understand the conceptual and practical changes in the 'construction' of 'Islam' and its social meanings in present-day Iran. Before I present evidence of such changes, however, I will report on the definitions of 'Islam' in the modern historical context of Iran.

\section{'Islam' and 'Islamism' in the Iranian Context}

Here, by 'Islam', I mean the everyday-life meaning of 'Shi'ite religion' in the context of Iran during the large part of the twentieth century until the revolution of 1977-1979. Although 'Islam' was an organizational religion and a major social institution, it was largely kept separated from the institution of politics. Iran had undergone a major socioeconomic transformation as result of the Constitutional Revolution of 1905-1909 (Abrahamian 1982). A new mostly secular judiciary and a 'modern' centralized state were in place. Urbanization, industrialization and bureaucratization, as well as educational, communicational and military developments had progressed enough to assume that traditional forces, namely the clergy and their bazaar allies, would be unable to seriously threaten the Pahlavi regime. In other words, 'religion' as a social institution was undermined, as expected, due to systematic 'modernization' and deliberate, top-down 'secularization'. Like many other societies, 'religion' did not vanish, but was rather pushed to the corners of everyday life, mainly among members of the petit bourgeoisie and rural areas. In order to be an ideal 'religious' Shi'ite person, it was sufficient to have some ethical integrity, to maintain cleanliness in religious terms (taha' rat), to pray five times a day, to fast during Ramadan, to pay religious taxes (khoms and zakat), to perform pilgrimage (to Mecca if wealthy enough, Mashad or Qom if less wealthy) and to commemorate the birth and/or death anniversaries of the Prophet and Imams, especially Imam Hussain, in addition to belief in God, his Prophets and the twelve Imams. A 'true Twelver Shi'ite' person would also wish, mostly passively, the return of Imam Mahdi, the twelfth and Hidden Imam in order to bring about social justice and peace on earth, cleansing it of alleged corruption and pervasive injustice. The apolitical clergy, trained in seminaries, played a central role in any number of these practices and beliefs. Mosques, which are traditionally built in the centers of cities and towns, as with bazaars, were the official offices of the clergy, providing 'religious' advice in relation to 'Islamic' practices and providing the setting for collective prayers. A major feature of these seminaries, and indeed the Shi'ite clergy organization, was their financial independence from the government, which was secured mainly by their bazaar petit bourgeoise allies (Ashraf 1988).

Although the mainstream of the Shi'ite 'ulama remained apolitical and quietist before the Revolution of 1979, political Islam had managed to survive in different forms: whether in individual or collective, progressive or reactionary, violent or peaceful, ways. Ayatollahs Seyyed Hassan Modarres and Abul-Qasim Kashani were individuals who played significant roles in the National Assembly until the early 1950s. However, as Arjomand (1989, p. 94) suggests, 'Islam' in its most politicized form emerged in the late 1940s due to the terrorist activities of a group of young clerics called Fada'iyan-i Islam (Devotees of Islam) who successfully assassinated the Prime Minster Razmara and the well-known 'secular' historian Ahmad Kasravi, as well as attempting a few other unsuccessful assassinations. The 'uprising of 1342 [1963]' by the seminary of Qum, which led to the exiling of Ayatollah Khomeini in the following year and thus the agitation of a segment of the Shi'ite 'ulama, provides further evidence for the presence of the political ideology of 'Islamism' at that time. Since then, there was a gradual amalgamation of Islamist forces with mostly Western-educated intelligentsia 
and what might be called 'liberal' activists, who were shaken by the 1953 Coup, which, together with other factors, paved the way for the revolution of 1979.

Among the intelligentsia, as Abrahamian (1982, pp. 462-73) highlights, the Sorbonne-educated Dr Ali Shari'ati's role is perhaps critical and incomparable with others, such as Ayatollahs Taleqani, Beheshti and Motahhari. Having said this, his modernist support for democracy and social justice was largely ignored in the post-revolutionary era and Ayatollah Khomeini refused even to mention his name amongst the influential figures (Godazgar 2000). Influenced by revivalist movements against colonialism and imperialism, especially in north Africa, and intelligentsia, such as Frantz Fanon, Dr Shari'ati blew a new spirit to the dying body of Islam among the educated youth by politicizing it and making it relevant to the modern world. He distinguished between Safavid Shi'ism ('tashayyo'e safavi'), which he described as quietist, and Alavid Shi'ism ('tashayyo'e alavi'), meaning 'true Shi'ism-the exemplary of which was its first Imam, Ali' — which was supposed to be revolutionary. He also intensely criticized the Islamic 'ulama, who were viewed as 'ignorant' of the main message of 'Islam' and the main philosophy of Imam Hussain's uprising against despotism and the aristocratic rule of the Umayyad Caliph, Yazid bin Mo'avieh. His lectures in the modern building of the Hussainiyeh-e Ershad in north Tehran were widely published and attracted the attention of many educated youth. These publications along with other 'Islamic' publications, 'mushrooming' religious associations and Islamist guerrilla organizations, boosted the 'religious' sentiment of the public to the extent that the Qur'an became the bestseller in 1973, with 700,000 copies sold, while Mafatih al-Jenan [Keys to the Heaven], a very traditional Shi'ite book composed of highly other-worldly prayers, became the second bestseller, with 490,000 copies sold (Arjomand 1989, p. 92).

It was interesting and perhaps shocking, as Milani (2011) elaborates, that the Shah himself and his omnipresent intelligence service, titled 'SAVAK' (National Organization for Security and Intelligence), ignored such 'Islamist' revivalist activities and the ensuing atmosphere until it was too late. The Shah thought that 'Islam' and the clerics were in general uninfluential, except as appropriate tools in combating leftists. Furthermore, in his view, activist Islamists, whom he regarded as 'erteja'e siah' $\left(\right.$ radically reactionary $^{1}$ ), were, he thought, too few to have any impact at a societal level. The global secret services, such as those of the USA (Emery 2013, p. 621; Halliday 1999, p. 172), the UK (Ansari 2019) and the former Soviet Union (Volkov 2019; Halliday 1999, p. 172) agreed with this analysis, as did scholars, such as Nikki Keddie (1983, p. 579), Fred Halliday (1999, p. 188), Michel Foucault (1978) and Edward Said (1980, p. 23) and indeed many leftist and rightist European and American intelligentsia or 'political scientists of all stripes', as Halliday (1999, p. 172) explains. It was against such expectations that the Iranian revolution finally, and so rapidly, happened, toppling the well-armed and Western-supported regime of the Shah under the banner of the political ideology of 'Shi'ite Islam' and 'religion': what I refer to in this article as 'Islamism'.

In the post-revolutionary era, 'Islamism', amalgamated with 'cultural nationalism' and 'populism', have ruled Iran with varying degrees (Godazgar 2008, pp. 62-80). 'Islamism', in this context, means that 'Islam', as the highest-ranked social institution with its so-called 'agents' (clerics), 'is fervently believed to be the foundation of a good society, and the whole society should be based on Islamic values.' (Godazgar 2008, p. 75). 'Islamic values' embrace the political ideologies of anti-Westernism, anti-imperialism and anti-Zionism as well as a specific stress on 'being welded into the principle of Jurist Guardianship' (zob shodan dar vali-e faqih), as the 'Deputy of the Hidden Imam'. This would also require an acceptance of theocracy and active participation in mosques as the official and legitimate centers for worship and Shi'ite rituals. The commemoration ceremonies of Imams, especially Tasu'a and Ashra, were transformed into political statements in favor of the Islamic authorities. This was achieved by holding religio-political requiems and by portraying the images of the authorities, in

1 The literal translation of 'erteja'e siah' is 'black reactionary.' However, 'radically reactionary' conveys a clearer contextual meaning of the term in English. 
particular that of Ayatollah Khomeini. For the first time since perhaps the influential rule of Shah Abbas I (1588-1629) of the Safavid Empire (1501-1736), during which official Friday prayers were established under a Shi'ite state, comparable to those held in the Sunni Ottoman Empire, Friday prayers were established in an official and organized way in July 1979 (Algar 2011). In mosques and Musallas (venues for Friday prayers), people were now required to listen to government-authorized clerics and to defend 'Islamic values' and the Islamic Leader as the 'Hussain of our time' as part of their 'Islamic' duty of 'enjoining good and preventing vice' (amr be ma'aroof va nahy az monkar). A further aspect of these newly defined 'Islamic values' was a specific stress on sex segregation and the veiling of women as a means of imposing moral purity. Indeed, as Amid-Zanjani (Amid-Zanjani 2012, pp. 41-42) stresses in the quotation above, mosques, scattered across the cities, towns and villages of Iran, provided critical bases and networks for the dissemination of these politicized 'Shi'ite values' or 'Islamism' and other revolutionary activities, including the mobilization of the mass ('Basij') to voluntarily participate in the Iraq-Iran war (1980-1988), during the revolution and in the early life of the Islamic Republic. Forty years after the revolution, the Islamic Republic of Iran and the religio-political ideology of 'Islamism' are still in place. Yet, the question I address here is: Are people still loyal to such 'Islamic values'? If not, what are their definitions of 'Islam' in today's Iranian context? Are mosques still functioning as the major sites of the Iranian Muslims' 'religiosity'? If not, what are the alternatives, if any?

\section{'Islam' in Its Fourth Decade: Methods and Findings}

In this article, I argue for two major points: first, that there has been a decline in mosque-centered Islam, which has taken on a different meaning than it had in both pre- and revolutionary eras; and, second, that there has been a rise in individualized or semi-individualized 'spiritualistic' Islam, which is distinguished from 'Sufism' and the 'spirituality' of ancient Iran found in 'religions' such as Mandaeism, Manichaeism and Mazdakism (Foltz 2004). I have adopted a triangulation research method in order to demonstrate the above-mentioned trends. For the former, I have used media sources that cite the general complaints of Iranian mosque leaders as well as participant and non-participant observations. For the latter, I have gathered data through participant observation and semi-structured interviews with thirty individuals in three provinces in north-west Iran.

(a) Decline of mosque-centered 'Islam' and 'Islamism'

According to Shi'ite jurisprudence, until the establishment of the Islamic Republic of Iran in 1979, Friday prayers were largely believed to be solely performable under the imamate of an 'innocent Imam' ('Imam-i ma'soum'), i.e., the twelve Imams. However, some jurists disagreed with this conventional belief and therefore there have been cases of performing Friday prayers in different eras, including the Pahlavi period, in mostly major cities, such as the capital (for more information, see Algar 2011). Yet, such prayers were significantly incomparable with those of the post-revolutionary era, in terms of both forms and scopes. In post-revolutionary Iran, Friday prayers were established and institutionalized in a centralized form by the Islamic leader as the legitimate Shi'ite authority (vali-e amr), who was involved in the appointment of Imam Jom'ehs in cities and towns throughout Iran. The first Friday Prayer was established with the Imamate of Ayatollah Seyyed [descendant of the Prophet] Mahmud Taleqani, who was widely regarded as a 'liberal and open-minded' Islamic scholar, in Tehran on 28 July 1979. Ayatollah Khomeini gradually appointed Imam Jom'ehs for other Iranian cities soon after. As long as he was alive, although all Friday Prayers were established in a centralized form, their sermons ('khotbehs') were non-centralized. That is, it was up to each Imam Jom'eh to decide what he needed to say to his audience during his sermons. However, during his successor's leadership, all Friday Prayer sermons were directed throughout the country by the Central Headquarters of the Friday Prayers (Setad-e markazi-e namaz-e jom'eh), which was established in 1990. Its defined goals were: 'the expansion [of Friday Prayers] in order to promote the awareness of mainly the youth and teenagers towards religio-political affairs and a full imitation of the Guardianship of the Jurist (vilayat-e faqih)', 'defending the values of the Islamic Revolution' and 'the encouragement of the people to participation in society and collaboration for the advancement of the goals of the regime of the Islamic Republic 
of Iran.' (Khatami 2019) This means that all appointed Imam Jom'ehs throughout the country have been required since then to follow orders in terms of what to say in their sermons in each Friday Prayer, which they receive weekly from the Islamic Leader, who is himself officially the Imam Jom'eh of Tehran.

On the fortieth anniversary of the establishment of the first Friday Prayers, Ayatollah Ahmad Khatami, the ultra-conservative Temporary Imam Jom'eh of Tehran, alongside other Islamic Leader-appointed Imams of Jom'eh throughout the country, acknowledged on Friday 26 July 2019 that Friday Prayers have become 'empty'. Confirming that Friday Prayers are 'the microphones of the Vilayat [the Guardianship of the Islamic Jurist]', Khatami called for assistance from the media in this regard: '.. the audible, written and virtual media are to help Friday Prayer[s] and not to be content that Friday Prayer[s] have become empty' (Khatami 2019). The dramatic decline in the number of participants in prayers is neither new nor confined to Friday Prayers. This has been a subject of discussion especially among 'reformist' newspapers, such as Bahar and E'temad, since at least May 2017, but this was the first time that this issue was acknowledged by Friday Imams themselves, who describe such a decline as 'dangerous'.

The 'emptiness' of Friday Prayers is also confirmed by Ayatollah Mohsen Gharavian, an influential member and teacher of the Qum seminary of Hawzeh Elmiyyeh: 'Friday Prayers lack the previous status nowadays. The main reason for the lack of people's participation, especially the educated youth, in Friday prayers is the weakness of their analytical and scientific contents, which either does not exist at all or hardly exists' (Salam-i No 2019). By suggesting this, Gharavian is implying that Friday prayers have simply turned into political ideological propaganda and people are not interested in this anymore. This is also confirmed by a retired professor of political sciences at the University of Tehran, Sadiq Zibakalam. In an interview with E'temad newspaper, he attributes the decline of participation in Friday and collective prayers in mosques to the 'politicization of prayers and the incorporation of the microphones of prayers into the government structure' and suggests: 'we witness the microphones of Friday and collective prayers have no independent views from the ruling [establishment] and what is requested from the Imams [of Jom'eh and Jama'at] is echoed from these microphones.' (Khatami 2019; Salam-i No 2019). It is interesting that, in a report about Friday prayers in Iran in the last forty years, Deutsche Welle, a German broadcaster, illustrates the change that has taken place from the mainly youthful participation of the Friday prayers in the early years of the revolution to the 'grey hair' participation nowadays (Khatami 2019).

The dramatic decline in the participation of prayers is not restricted to Friday Prayers or 'musallas', where Friday prayers take place. It also includes mosques and the daily Collective Prayers (namaz-e jama'at). This was also acknowledged by Ayatollah Ali Khatami, the Imam Jum'eh of the major city of Zanjan in the north-west Iran on 28 May 2019, in complaining about the 'emptiness of collective prayers in mosques' and calling it 'a cultural concern that requires appropriate cultural tasks' (Khatami 2019). Indeed, the decline of the mosque-centered and organized 'Islam' and 'Islamism' is also confirmed by the participant and non-participant observations that took place in mosques and musallahs in north-west Iran. Despite the fact that the offices of the Headquarters in each city provides free transportation to the centralized Friday Prayer venues (musallas), they were frequently observed to be mostly empty. Instead, the Friday Prayers' audiences are packed with soldiers or, on some occasions, school pupils who are forced to attend such prayers. Similarly, the number of attendees in Collective Prayers in mosques, which are mainly situated in the populated areas of the bazaars, often did not exceed one row, especially during noon prayers.

The decline of mosque-centered 'Islam' and 'Islamism' was also confirmed by the interviews. Out of thirty, only seven informants stated the 'mosque' as a venue for their 'Islamic' activities—of which, only two mentioned the 'mosque' as their sole and exclusive venue. That is, the other five informants merely gave preference to the 'mosque' over other possible venues with different degrees and reasons. A forty-five-year-old male civil servant with a degree in Islamic Jurisprudence, who solely chose the 'mosque', stated: 'Mosque is the best and the most appropriate place for the [moral] training of teenagers 
and the youth, expressing your personal feelings ['ehsasat-e shakhsi'] and acquiring inner peace ['araamesh-e darouni']. It is the house of God.' Another informant, a twenty-six-year-old woman and teaching fellow at a university with a family background in the revolutionary guards, mentioned:

'In my view, the faithful must choose mosques, which are the houses of God, but the majority of the Iranian people prefer to make pilgrimages to Imams' or Imamzadehs' tombs rather than attending mosques these days. Mosque is the house of God and, in my view, is the most sacred place for [having] conversations [with God] ['raz va niaz'] and for the expression of religious emotions ['ehsasat-e mazhabi']'.

It was interesting that even these two informants, who solely chose the mosque as a venue for their 'religious' activities, mentioned no term related to 'political Islam' or shari' $a$ as part of their 'religious' commitment or sensation for attending mosques. These interviews and the non-participant observation also confirm that the decline of participation in Collective and Friday prayers has not occurred over night, but has happened gradually over the past forty years, especially during the last two decades. I now turn to the question of 'Where have the congregations gone?' and 'What has happened to their "religiosity"?'

(b) Rise of individualized or semi-individualized 'spiritualistic Islam'

My strategy for this part of the research comprised participation observation in the three provinces of East Azarbaijan, West Azarbaijan and Ardabil, which are situated in north-west Iran, as well as thirty semi-structured interviews focused on Tabriz, the capital city of East Azarbaijan in 2015-2017. ${ }^{2}$ Participant observation included observations of mosques and 'Imamzadehs' (the tombs of presumed grandsons of Shi'ite Imams), 'maqbarahs' (the tombs of reputed saints), Friday prayer venues called 'musallas', university mosques, 'Hussainiyehs', congregation halls for commemoration ceremonies of Shi'ite Imams, and public spaces such as streets, especially during the Shi'ite rituals of Tasu'a and Ashura. This method was adopted due to the 'complexity' of the social context in which 'religious' change was occurring (Darlington and Scott 2002, pp. 74-76; Atkinson and Coffey 2001, p. 812). In addition, after identifying the fact that there were other groups of Iranian Shi'ites that avoided public spaces for performing their 'religious' sensations, a snowball sampling method was adopted in order to interview further informants who were not easily visible for 'ideological or political reasons' and given the 'sensitivity' of the topic (Corbetta 2003, p. 222; Gray 2014, p. 223). However, in order not to compromise the diversity of the sample frame, I made sure to specify the required characteristics of new sample members from diverse backgrounds in terms of age, gender, education, marriage, occupation and social class (Ritchie et al. 2003, p. 94; May 2011, p. 145; Gray 2014, p. 223). It was important to make sure that the diversities of the definitions of 'Islam' were explored.

In terms of the analysis of the qualitative data, influenced by Asad (1993) and Foucault (1972), and due to consistency with the theoretical approach of 'social constructionism' (Beckford 1989, 2003), this project has adopted a 'Critical Discourse Analysis' approach, according to which 'discourses',

2 The Province of Ardabil was a part of the Province of East Azarbaijan until March 1993. The vast majority of these three provinces speak the Azarian Turkic language and are Twelver Shi'ite Muslims. They also border the Republic of Azerbaijan in the north with the same name, language and religion (Shi'ism). The Republic of Azerbaijan, along with other Caucasian territories (namely Georgia, Armenia and the Republic of Dagestan), was a part of Iran until the 19th century, when Iran lost these territories to Russia during two wars (1804-1813 and 1826-1828). Although the Republic of Azerbaijan, on the one hand, and the Iranian provinces of Azarbaijan (along with those of Ardabil, Zanjan and to some extent Hamadan), on the other, share the same language and religion, they are sharply divided in terms of politics and the definitions of what counts as 'Islamic Shi'ism'. After all, they have historically experienced totally different discourses during the last two centuries. The Republic of Azerbaijan has been subject to Imperial Russian and Soviet rule for around two centuries, with literally little relationship with Iran, including the Azarbaijan provinces. In addition, like other parts of Iran, many Iranian Azarians consider the territory of the Republic of Azerbaijan and others as the lost lands and blame the Iranian Qajar dynasty kings for these losses. Therefore, the 'religious' lives of the people of all these three provinces are typical of Iranian society, rather than being similar to those of the Republic of Azerbaijan. Indeed, this is also very clear from the critical roles these provinces have played in Iranian social upheavals such as the Constitutional Revolution of 1905-1909 and the 'Islamic' Revolution of 1977-1979 (for more information in this regard, see Abrahamian 1982). 
in the sense of patterns of beliefs, customary actions and language, are major conventional ways via which 'ideology', in the sense of 'a set of interrelated ideas' that are associated with power, are produced, re-produced and disseminated (Johnstone 2002, pp. 45-55). That is, I attempt to identify and comprehend the discourses, portrayed via participant observations and semi-structured interviews, by exploring the meanings of our informants' forms of language and activities and trying to find 'ties' or connections between these forms in order to understand the power structure and its impact on the society in which the properties of change and continuity occur (Van Dijk 2001, pp. 352-58; Georgakopoulou and Goutsos 2004, pp. 14-22). All informants, apart from one, were from Shi'ite backgrounds. Due to the flexibility of the method and giving priority to the identification of, and understanding the quality, of change, a semi-structured method of interviews was adopted (Burns 2000, pp. 424-25; Kvale and Brinkmann 2009, p. 130). The interviewees represent mainly lower and middle classes from an age range of 18 to 62 years. There were 16 women and 14 men, with an educational level ranging from primary school to doctoral studies: four below the equivalent of GCSEs, eleven with GCSE, A-levels and national diplomas-equivalent qualifications and fifteen with bachelor's degree and above. Nearly half of them came from a state-employment background and the other half from a private sector or bazaar background. All the questions asked were about 'Islamic' activities and sensing 'religion', including when, where, and how these sensations and activities occur.

Using the above-mentioned methods, I argue here that Iranians have diversified the forms of their 'religiosity' by creating and defining a variety of new venues and forms of 'Islam' that are overall indicative of an individualized or semi-individualized 'spiritualistic Islam'. Following Beckford (2003, pp. 71-72), by 'spiritualism' (ma'anaviyat-garaei), I mean individualized, subjectivized and fragmentized definitions of 'Islam' that, under the influence of societal conditions and global forces, are 'socially constructed' in ways in which they go beyond the objective political or apolitical meanings defined by institutional or organized Islam in the Iranian context: the 're-location of the sacred' from 'institutional Islam' to 'individualized Islam'. In this sense, 'spiritualism' avoids and often loathes organized 'Islamism' or the political ideology of Islam, which has dominated the discourse of the revolutionary and post-revolutionary era, and also resists non-ideological and shari' $a$-centered 'Islam' as an institutional religion, which was the characteristic of pre-revolutionary Iran. For Beckford (2003, p. 72), these subjective or individualistic forms of spirituality are the characteristics of late modernity, to be distinguished from medieval Europe and the Pietist movement in 17th and 18th century Germany. In medieval Europe, Christian churches used and/or encouraged 'spirituality' as an institutional apparatus in order to regulate their members' lives in the form of training or discipline. In contrast, today's 'spiritualism' tends to embrace 'a variety of largely voluntary beliefs and practices which are expected to enhance the capacity of individuals to, e.g., realize their full potential or achieve "authenticity" to their "true" self-without any necessary connection to any particular religious tradition or institution.' (Beckford 2019). His main point is that there has been a historical shift in the definition of 'spiritualism' from the former to the latter:

'This shift ... is associated with very broad social and cultural changes such as the declining importance of 'attributed' identities (or status) and the rising importance of 'achieved' identities; the declining importance of membership in all kinds of voluntary organisations (churches, trade unions, political parties, etc.); the growth of 'identity politics'; and the growing interest in cultivating 'the self' as a life-long project which may produce different views of the self at different stages of life. These changes have all accelerated in the global and digital era (especially through social media); and they help to draw a clearer distinction between 'religion' (as a matter of collective discipline, regulation, tradition) and 'spirituality' (as something that is freely chosen to be cultivated by individuals).' (Beckford 2019)

Although this shift 'is most noticeable in the liberal capitalist world', it is not limited to it (for example, see Fedele and Knibbe 2013; Godazgar 2007). In this sense, my definition of 'spiritualized Islam' is distinguished from both 'Sufism' and the 'spirituality' of ancient Iranian 'religions' (Foltz 2004), although I believe that both of them are important 'cultural resources', to borrow Demerath's (2002, p. 21, cited in Beckford 2003, p. 72) term, for the present-day individualized 'spiritualistic Islam', 
which is 'modern' in Eisenstadt's (2003) sense. While, 'modern spiritualism' in the contemporary Iranian context shares to some extent with 'Sufism' elements of intercession (shefa'at), mediation (tavassol) and entreaty (talab-e hajat), especially in the act of pilgrimage to Imamzadehs, it does not share with it Sufism's critical element of having a tutelage (pir or morshed), which is highly hierarchical and organizational. That is, unlike Sufism, 'modern spiritualism,' in the Iranian context, is neither institutionalized nor organized. In addition, intercession in Sufism is mainly spiritual in other-worldly forms. Yet, intercession in 'modern spiritualism' can take both this-worldly (physical and materialistic) and other-worldly or metaphysical forms. Iranian 'ancient spiritualism' also has a commonality with 'modern spiritualism'. Both of them emphasize the significance of 'coming from the heart', 'genuineness' and lack of 'duplicity' (ri' $a$ and tazahor) and indeed any type of 'formalism', including institutional or organizational formations. However, 'modern spiritualism' is distinguished from 'ancient spiritualism' in the sense that the modern version is shaped by global forces and conditions of late modernity such as satellite TV, internet, migration and social media. In brief, 'modern spiritualized Islam' may be considered a response to a person's individualistic and subjective needs that arise from the new societal conditions that one might associate with 'late modernity' or 'post-modernity', which may be materialistic, metaphysical or psychological.

In terms of the question of whether my informants pursued an individualistic subjective or a universal objective 'Islamic' requirement, it may be concluded that they were predominantly in favor of the former. However, the extent of subjectivity among them was not the same, as is to be expected. Therefore, I have compared the degrees of their subjective spiritualism from various angles, as outlined below. That is, individualized or semi-individualized 'spiritualistic Islam' in the context of modern Iran takes various forms: venues, conceptualization of and relationship with 'saints', outward appearance of participants, impact of mass and social media, language, 'art' and 'music', and architecture. These different forms are designed to check to see whether Iranians in the modern context express the kinds of spiritualist tendencies predicted by the theory. What I find is that they do indeed express such tendencies, as in many other societies. Furthermore, what I find is that within the Iranian context, the popular meaning of 'religion' has changed since the revolutionary period.

\section{Diversification of 'Islamic' Venues}

As mentioned above, our informants did not restrict themselves to mosques as the only 'official' venue of organized Islam to perform their 'Islamic' commitments or sensations. They now have many choices: Imamzadehs, maqbarahs, Hussainyehs, Tekyes, university, streets, and even their own private spaces within their homes. That is, they did not feel required to follow the objective rules of institutionalized and/or politicized 'Islam' to use mosques in order to perform 'Islamic' collective prayers and rituals. Each individual chose the most appropriate venue for him or her at a particular time. Regardless of the kind of venue that is selected, 'spiritualism' (ma'anaviat-garaei) has taken different meanings:

(i) The foremost meaning of 'spiritualism' is an 'expression of personal feelings' or 'self-reflection', especially when a private space at a household is selected, for the purpose of 'acquiring inner peace' (frequency = 17).

a. 'The place is not very important. What is important is to be able to express my own [religious or spiritual] sensations. If convenient and on my way, I would rather [go to] Imams' or Imamzadehs' mausoleums. If this is not possible, I attend a mosque or any mourning event that takes place in a relative's or neighbor's household. In general, it does not make any difference whether it takes place in a household, Imamzadeh or any other place. The expression of my [religious] feeling is important.' (A 29-year-old woman with a general education background.)

b. '... Religion [in public life] is entertainment for human beings. I choose my [private] room in order to have [spiritual] self-reflection. Those who participate in [religious] rituals, in my view, lack 
something psychologically and they fear loneliness and [therefore] they need to fill their psychological vacuum ... ' (An educated 25-year-old man.)

(ii) 'Spiritualism' is related to the meaning of 'genuineness' and 'coming from the heart' aspect of so-called 'religious' activities, which avoids any form of 'religious formalism' and 'duplicity' and 'two-facedness' ('ria va tazvir') (frequency = 5).

a. '... If I want to choose to attend an event, I will choose one [in a venue] that is more genuine in terms of their [religious] intentions and lacks any religious formalism.' (A 23 year-old male student.)

b. '... I choose a place in which there is no duplicity (ri'a) and formalism (zaher-sazi). One that [is genuine and] comes from the heart ... I also like to make pilgrimages to the tomb of Imams ...' (An educated 24-year-old man.)

(iii) 'Spiritualism' is not just related to other-worldly demands and expectations. It embraces both this- and other-worldly needs (frequency = 3), although some may prefer 'simple' places to other venues due to the current difficult economic conditions (frequency $=2$ ). However, this does not mean that their form of 'spiritualism' is solely 'other-worldly'. This was particularly clear when our informants chose Imamzadehs as their 'religious' venue. This form of 'spiritualism' is particularly related to circumstances when one is 'depressed of and exhausted by the troubles of [this] world and needs a simple [peaceful] place' and therefore makes a pilgrimage to Imamzadeh's tombs as they are 'easily available' and they were believed to be 'simple persons', suggested an unemployed twenty-five-year-old educated woman. This may sound highly other-worldly. Yet, it is not explicitly chosen, as in Sufism. Rather, it is imposed by the deeply stratified social structure of contemporary Iran, in which some Iranians, such as the above-mentioned woman, resort to 'spiritualism' for gaining some peace. This is confirmed by another informant, a forty-five-year-old housewife, when she refers to 'not returning home with an empty hand', i.e., being answered to for usually mundane requests, as a reason for attending the tombs of Imamzadehs or mausoleums.

(iv) 'Spiritualism' means a direct association and a 'private conversation with God (raz va niaz ba koda)' and feeling Him, without any mediation (frequency =2). This meaning of 'spiritualism' may also embrace mundane issues.

(v) The final form of 'spiritualism' in association with venues is related to so-called 'musical' aspects of 'Islamic' festivals, such as playing drums or the flute, requiem (nouheh soraei) or rhythmic recitation of the Qur'an (frequency $=3$ ). It should be noted that playing musical instruments, such as drums and flutes, are considered 'haram' or 'forbidden' in 'Islamic' jurisprudence or shari'a. This will be elaborated on in more detail below.

In order to identify and understand the relationship between a chosen venue and 'spiritualism', I have tried to roughly quantify the subjective elements of my informants' interviews in terms of the venues they chose for their 'Islamic' practices in the hope that it may make the comparison more helpful. The highest degree of subjectivity belongs to those who selected or preferred their private space at homes for 'spiritual' sensations (frequency =6) and those who no longer had any 'religious feeling' or belief at all (frequency $=1$ ). This group's subjectivism may be quantified $100 \%$. The next group that scored highly for subjectivism comprised those who chose Imamzadehs with $84 \%$ (frequency $=6$ ). The third highest degree of subjectivized practices or rituals belongs to those who had no preference in choosing venues (frequency $=10$ ). They treated all venues as equal and their choice depended mostly on the 'quality' and the 'convenience' of the 'Islamic programs' on offer. They scored 70\% for subjectivism. Finally, the least amount of 'subjectivism' belonged to those who selected or preferred mosques for their 'Islamic' or 'spiritual' practices and emotions with a degree of $50 \%$ (frequency $=7$ ). 


\section{Conceptualizations of 'Saints' (awli'a)}

In addition to 'Islamic' venues, 'modern spiritualized Islam' in the Iranian context is also associated with the perception and conceptualization of important 'Islamic' figures or 'saints', such as the Prophet, twelve Imams (for Twelver Shi'ism), their descendants (Imamzadehs) and other 'spiritual figures', such as Sufis. Imamzadehs and 'spiritual figures' are perceived to be remarkably close to the divine, the Prophet and Imams. They are allegedly capable of portraying this closeness by performing miracles, especially curing (physical intercession). These 'saints' are also theoretically considered as 'mediators' between the divine and ordinary people. From this perspective, there is a commonality between 'modern spiritualism' and 'Sufism'. Indeed, it seems that pilgrimage to 'Imamzadehs' have become a dominant discourse in present-day Iran.

This research shows that my informants' understandings and definitions of these 'spiritual figures' have become so individualized and subjectivized that some of their 'constructions' may even attract dangerous allegations of blasphemy and, as a result, capital punishment. Their contextualized and individualized characterizations of different 'Imams' and/or 'Imamzadehs' can also be controversial, from the perspective of classical 'Shi' ism':

(i) 'Saints' as 'ordinary human beings' (frequency = 6): this group of individuals, who have selected their private spaces in their households for their 'religious activities', tended to bitterly desacralize 'saints' by calling them 'ordinary human beings' and sometimes even insulting them, such as:

a. 'all Imams were cowards, with the exception of Hussain, who was a brave man, and Ali, who considered all people innocent unless their guilts were proven.' (An educated 24-year-old woman.)

b. 'I don't even know the Imams' names, apart from a few ... We don't hear that Hussain was a "free man" anymore ... and he had nothing to do with people's religion ... Ali was a violent person ... I laugh when I hear "Hidden Imam" ... Imamzadehs are tools for entertainment by the government.' (A 23-year-old male student.)

c. 'I have no imagination about them. I have not experienced them.' (An educated 24-year-old woman.)

d. 'They were good people, like figures in other religions [implying that they were not special].' (An educated 30-year-old man.)

e. 'I have nothing to do with Imamzadehs, but I like Imams, especially Ali and Hussain for their spiritualistic and humanistic characters.' (An educated 45-year-old woman.)

f. 'They have done something that God has asked them to do [implying that they did not choose to do good things independently from God]. [Therefore] they have no superiority over us. They were people like us.' (A 26-year-old female student.)

Indeed, all these conceptualizations mirror the societal conditions of contemporary Iran-of which, this group of informants were brutally critical.

(ii) 'Saints' as 'innocents', 'examples', 'mediators' and 'great personalities' (frequency = 16): these are usually considered 'classical' characterizations of 'Imams' and/or 'Imamzadehs' (without the feature of 'innocence' for Imamzadehs). These characterizations were usually used by those who choose mosques, Imamzadehs and those who gave no preference to any particular venue. In contrast to point (i), these features go beyond features of an ordinary person. Having said this, the subjectivized and individualized conceptualizations of these 'saints' are noticeable among these informants too, even among those who chose or preferred mosques over other venues:

a. 'Imams are mediators [between God and people]. [However,] despite what many people believe, I do not maintain that they had authority to [conduct] miracles', an educated 26-year-old Shi'ite woman who preferred mosques stated. This goes against classical and institutional 
understandings of Shi'ism, and any such suggestion could result in allegations of apostasy and punishment.

b. 'Among Imams, I like Imam Hassan [the second Imam]. He was a peace-maker. He was a calm person and did not want anyone to be hurt.' (An educated 23-year-old man.)

c. 'I like Imams, especially Imam Hussain. He was a symbol of kindness and sacrifice and fighting oppression. I wish there was an Imam in our time too [implying that the Islamic Leader is not an 'Islamic' figure, but a political one]. Ali was strong but he never used his strength in a bad way. He was not violent ... Fatemeh [the Prophet's daughter, who is conventionally believed to be 'innocent' but not an Imam] was rich, but she was humble and had a simple life.' (A 29-year-old woman with a general education background.)

d. 'I respect Imams and their descendants, even an unveiled seyyed [descendant of the Prophet] woman [meaning that she does not care about shari'a] ... They are symbols of kindness, calmness, forgiveness and patience. They tolerated a lot of difficulties because they wanted us to live in calmness and establish a [spiritual] relationship with God', an educated 33-year-old female informant said. It should be noted that she does not mention that Imams tolerated such difficulties because of shari'a or the political rule of Islam.

e. 'I like our Imams and Imamzadehs. Some Islamic beliefs have nowadays changed. People do not respect such figures as much as they did before. They suggest that these saints do not belong to our culture and civilization, as they are Arabs. As we do not have a good relationship with Arabs nowadays, they avoid [respecting] these figures. They have independent personalities and I respect them a lot.' (An 18-year-old male student.)

Although these informants' conceptualizations of 'saints' mirror the classical understanding of Shi' ite figures in general, their specific and selective characterizations of these 'saints' are indicative of an 'individualized and subjectivised Shi'ism' that is to a great extent critical of both the post-revolutionary 'Islamism' and pre-revolutionary 'Islam', which tended to respect all Imams equally, in the context of the contemporary Iran.

(iii) 'Saints' as 'saviors and helpers' (frequency = 4): this meaning of 'saints' seemed to be an emerging trend. Due to perhaps economic difficulties and hardship within society, there was a tendency to the view that there is no use in 'crying' for or 'mourning' Imams' death in their commemorations. If one wants to be 'faithful' or 'spiritual', s/he should help people, as the 'Imams' supposedly did:

a. 'They [Imams and Imamzadehs] are good listeners [when one makes a pilgrimage to their tombs] and most hospitable individuals who will help you.' (A 27-year-old female student.)

b. 'They are good mediators in helping people to sort out their problems.' (An educated 30-year-old man.)

c. 'They [saints] are like our fathers and can help us ... I should submit my project [at the university] by next week and I pray a lot to Imams to assist me in doing so!' (An 18-year-old female student.)

d. 'I have no special feelings to Imamzadehs, but I have a lot of respect for Imam Reza, who saved my life when I was nine-years-old and suffering from a serious illness. My father vowed when I recovered, we would make a pilgrimage to Imam Reza ... He [Imam Reza] is the kindest, strongest, nicest and the most knowledgeable person.' (An educated 25-year-old woman.)

As we see, a 'spiritualistic Islam' in relation to the conceptualization of 'saints' in today's Iranian context has taken mainly three forms: desacralization, differentiation between Imams mirrored by the conditions of society and/or making them relevant to their individual circumstances and needs.

\section{Relationship with 'Saints' (awli' $a$ ) and 'Religious' Experience}

Given the respect that many Iranian Shi'ites have towards their 'saints', especially Imams and their descendants, it is also important to know why, how, when, where and how often they 'socially 
construct' their relationship with their perceived 'saints' and how a 'religious' or 'spiritual' experience occurs. Although, some of them may attend a collective ceremony or ritual on certain occasions, such as Ashura and Qadr Nights ${ }^{3}$, they emphasized that they do so in order to have a 'richer' individualistic 'spiritual' experience in such ceremonies—not in order to be a part of a group identity or to take part in collective religious behavior. Interestingly, I did not find a sharp contrast between the experiences of those who selected private spaces and those who chose other venues in this respect. However, the members of the former appeared stricter than those of the latter in avoiding public spaces even during such important occasions. In any case, a great degree of these experiences may be characterized as part of individualized and subjectivized 'spiritualistic Islam':

(i) 'Facing social or personal problems' (frequency $=16$ ): The high frequency of 'problems' as a reason for having 'religious' or 'spiritual' experience among this group of individuals indeed illustrates the contextualized feature of these experiences and the difficult social conditions they lived in. Twelve, out of the sixteen, were women. In addition, these individuals tended not to allocate a specific time or occasion for having their 'religious experience' and connecting with the divine or the 'saints'. They did it as they felt they needed. Interestingly, the majority of these individuals is composed of those informants who suggested that they had no preference in choosing a specific venue. Some examples of the statements in this regard are as follows:

a. 'I see sometimes injustices and I wish Imam Ali was here. Since I have no access to him, I go and talk to his descendants, i.e., Imamzadehs.' (An unemployed, 24-year-old educated woman.)

b. 'When I face a problem and I need something, I go to Imamzadehs as I am aware that there are more positive vibes there. This is the case with the Imams' shrines too. There is more hope [in shrines, as opposed to mosques] that your requests will be answered.' (An educated 33-year-old housewife.)

c. 'When I face an issue or difficulty [and] when I need someone, I think of them [Imams]. I ask for help from them from my heart. I request to them to mediate between me and God in order to respond to my needs and problems.' (An unemployed 23-year-old educated man in obligatory military service.)

d. 'It [spiritualism] is not easily describable. It usually comes to me when I face a disaster or I am happy with something. [On these occasions] I say 'al-hamd-o lellah' (thanks to God) a lot. When I get caught up in a spiritual condition [halat-e ma'anavi], I repeat this word [al-hamd-o lellah]. When I see an ill person in my surrounding, I thank God that I am healthy.' (A 33-year-old educated housewife.)

e. 'Whenever I have a problem or I have been given something by God, I connect to God by thinking of Him and thanking Him directly. I sometimes ask the Prophet to mediate too.' (A 24-year-old woman with a National Diploma, who was unemployed.)

(ii) 'Special occasions' (frequency = 11): Unlike the above-mentioned informants, these individuals restricted the definition of 'religious experience' to specific festivals and occasions. Some of them emphasized that they had a lot to do for the rest of their time. Therefore, they could only afford certain times for such a relationship and experience, i.e., in specific occasions that are 'religiously' considered to be important, such as the days of Tasu'a and Ashura (9th and 10th Moharram, when it is believed that the third Imam, Hussain, and his seventy-two helpers were martyred), the Qadr Nights and perhaps the Prophet's and/or other Imams' death anniversary ceremonies. These individuals can be found across all selected or preferred venues. In other words, these occasions were considered important for many informants. However, seven informants, out of

3 Many Iranian Shi'ites commemorate three nights of Ramadan (17th, 19th and 21st) by staying up alone or attending gatherings at 'Islamic venues' for prayers and reciting the Qur'an as they believe that the Qur'an was revealed to the Prophet on one of these three nights. These nights are called the 'Qadr Nights' (the grand nights) or 'Ahya Nights' (the awake nights). 
eleven, belonged to the group of individuals who preferred Imamzadehs for having a 'religious' experience on such occasions.

a. 'I get caught up in "religious experience" during [the months of] Moharram and Ramadhan and [Imams or the Prophet's] martyrdom anniversaries (ayyam-e shahadat). I have no [religious] experience on other days.' (An 18-year-old female pupil.)

b. 'When I get bored, I get caught up in religious sensations. Of course, it may also occur when I am happy too. On these occasions, I feel that I should be grateful to God by thanking Him. [However,] the months of Ramadhan and Moharram are the occasions when I have the most religious experiences.' (An educated 30-year-old man.)

c. 'I usually experience a religious feeling during the days of Moharram, especially Tasu'a and Ashura, and the Qadr Nights and perhaps on some other occasions.' (A female PhD student.)

d. 'I may feel a religious sensation on ordinary days, for example, by thinking about one of our Imams. Yet, it has also happened that I did not have such a sensation even during the [Imams' or the Prophet's] martyrdom days. There was no difference between those days and other days for me. It depends on my conditions at that particular time.' (An educated 25-year-old housewife.)

(iii) 'No need for special occasions' (frequency =3): These individuals' definitions of 'religious experience' may differ from one extreme to another (for example, compare points a and $b$ below). While the former may experience a religious sensation once a year, the latter rules out even a minute for lacking religious experience.

a. 'You cannot allocate a time for such an experience. Whenever your soul needs it, it comes.' (An educated 32-year-old man.)

b. 'Religious experience has no special time. A human being must see themselves in the presence of God (dar mahzar-e khoda bebinad) all the time. Special days such as those of Moharram are also important because these help us to understand and disseminate the ideas and beliefs of Imams. People get more prepared [for religious experiences] in these days.' (An educated 48-year-old man.)

c. 'I used to have it perhaps everyday [meaning while performing daily prayers], but it is not the case anymore.' (An educated 30-year-old man.)

(iv) 'No religious experience at all' (frequency $=3$ ): These individuals were very critical of the condition of society and did not consider themselves to be 'religious':

a. 'I have no understanding of a religious experience, because I have not experienced it.' (An educated 30-year-old man.)

b. 'It depends on my [individual] condition [bastagi be halam dard]. In Iran, the so-called 'religious ceremonies' (marasem-e mazhabi) are in fact a type of [social] gathering and lack any 'religious' or 'mourning' (azadari) character. For example, in the day of Ashura, you should either stay at home or come out and observe thousands of these groups. I do not attend them. Each is worse than the other. You can hardly find anyone that is genuinely 'religious' ... I know mourning groups (hey'at-haye azadari) that commit unethical things throughout the year, but they [suddenly] become 'religious' in Tasu'a and Ashura ... This is why I have a problem with "religious people". They use "religion" for their own personal and economic interests... I know an owner of a coffee-house, who is the only one in the city who sits behind his desk with a suit. You know why? Because a famous 'maddah' [the person who performs Shi' ite requiems] frequents his coffee-house. In this way, the status of his coffee-house goes up and he receives more customers and then charges each person 4000 Tomans, instead of the 1500 Tomans that other coffee-houses charge ... This owner respects Ashura more than anyone else. He even gives free food for Imam Hussain's mourners (azadaran) on the Day of Ashura. Why not? He has already made a lot of money out of it ... Religion is an instrument of power to make a lot of money.' (A 23-year-old male student.) 
c. 'I do not need such things [religious experiences] ... I could not find anything in them [religious ceremonies] that I was after ... Formerly, I used to pray to Imams whenever I was upset or I needed something. But I do not need these things anymore. If I have a word to say, I may say it to God [directly], not to his servants [human beings].' (A 26-year-old female student.)

As we see, 'subjectivized spiritual Islam' has taken a variety of forms ranging from responding to personal needs to no need at all.

\section{Constructions of 'Outward Appearance'}

It was important to find out the implications of 'spiritualized Islam' on individual behaviors in relation to their outward appearance when the informants wanted to attend an 'Islamic' ceremony and/or having a 'spiritual' experience. Did 'spiritualism' mean making alterations to their appearance? This question was important because it was traditionally a norm that men and women wore black clothes in Moharram (and even a part of the next Islamic calendar month, Safar) and men did not shave their beards on certain 'religious occasions', such as Tasu'a and Ashura. In addition, it was important to assess the extent to which present-day Iran is influenced by a culture of 'simplicity' stressed by Sufism and/or global forces and late modernity. My findings show that individual behaviors are not unanimous and uniform. Although the majority of the informants pursued a subjectivized approach towards choosing how to appear, there were some informants who acted objectively in this regard (frequency $=23$ vs. 6). That is, it mostly depended on each individual to choose how to express their 'religious experience' on these 'Islamic occasions'. Indeed, given the high respect of Iranian Shi'ite Muslims to Imam Hussain and the commemoration of his death by changing their usual outward appearance in the past, the greater degree of an individualized approach in this regard was rather surprising.

(i) 'No change' (frequency =7): These individuals changed little in terms of their outward appearance for attending a 'religious' ritual and/or experiencing 'Islamic spirituality':

a. 'I want to be myself all the time, well perhaps $90 \%$ of the time. That is, if I make up my hair and face on ordinary days, I do the same on these special 'religious' days too. I may wear a black shirt one day in Ashura out of respect to Imam Hussain.' (An educated 23-year-old man.)

b. 'I do not need to change my outward appearance and wear black clothes Iin Moharram due to Hussain's martyrdom].' (An educated 24-year-old woman.)

c. II do not change my outward appearance. Some people may grow a beard or wear black shirts, but I do not do these things.' (A 23-year-old male student.)

(ii) 'Formal, nice and clean' (frequency = 5): These individuals paid most attention to their appearance on such occasions, as though they were visiting relatives or friends. In fact, it was considered an opportunity to show off, especially when they were attending a 'religious' ceremony in a household. It was interesting that most of these informants later mentioned that they would rather use internet and satellite TV for their 'religious knowledge' than state TV.

a. 'If there are ceremonies in people's households, I pay attention to my dress as if I am attending a party. Otherwise, I do not change my outward appearance.' (An educated 45-year-old woman.)

b. 'I wear pretty and clean clothes as if it is an Eid [she means that she does not change her outward appearance because her religion].' (An educated 24-year-old woman.)

(iii) 'Simple and modest' (frequency $=4$ ): In contrast to the above-mentioned individuals, there were those who wanted to establish a 'religious' experience whether privately or publicly in a clean but simple and modest way. Some of these informants criticized those who attended such 'spiritual' meetings in 'posh' attire 'as if they are going to a wedding'. This group of individuals were perhaps unwittingly influenced by a non-materialistic Sufi culture of 'Shi'ism': 
a. '[Out of respect] if I go to Imamzadehs and mosques, I try to pay more attention to my 'hejab' (veiling). Otherwise, I do not make any changes.' (A 29-year-old woman with an A-level education.)

b. '[In Ashura and Tasu'a] I try to wear simple clothes, [although] in my view, [the change] of outward appearance is not important.' (A 27-year-old female student.)

(iv) 'Appearance in accordance with the character of the religious gathering' (frequency $=7$ ): For such individuals, outward appearance should be consistent with the aim and nature of such a gathering. For example, if they were to attend an Imam's or the Prophet's birthday ceremony, they should appear in bright colors. In the same way, they would choose dark colors, mostly black, and perhaps humble dresses for the commemoration of the death anniversary of the Prophet or an Imam.

a. 'If there is a formal gathering, I dress formally ... In general, I choose my dress in accordance with the nature of a gathering.' (An 18-year-old pupil.)

b. 'Every event requires its own attire. It is not appropriate to wear wedding clothes for mourning and vice versa. I like to choose my clothes accordingly.' (An educated 25-year-old woman.)

(v) 'Following "Islamic" orders [mainly meaning shari'a or tradition]' (frequency =6): It would not make that much difference for this group of individuals where and in what type of ceremony they wanted to attend. It was just important to objectively observe the appearance requirements of 'Islam', such as strict hejab and wearing black shirts, not just for that certain ceremony but for a period of time, ranging from 10 days to two months during the Islamic months of Muharram and Safar. The latter (wearing black clothes) was viewed as a requirement of tradition, but not the shari'a.

a. 'If it was up to me, I would not change my outward appearance. Yet when I consider others, I wear black clothes ...' (An educated 25-year-old woman.)

b. ' ... In the martyrdom days, I wear a black shirt. When I was young, I grew a beard too, but I do not do this these days.' (A 54-year-old man.)

As we see, although there is an observable level of objectivity towards the requirements of tradition and culture, rather than those of Shari'a, in relation to outward appearance, a greater extent of subjectivized and individualistic 'Islam' is portrayed in this regard compared to the revolutionary and pre-revolutionary eras.

\section{The Impact of Mass and Social Media}

In addition to the diversification of 'Islamic' venues, Iranian TV or radio as well as the internet and a variety of social media contributed to the individualization of 'Islam' among my informants, in cases when they were not able to physically attend 'Islamic' festivals. Indeed, this dimension sheds further light in terms of differentiating between 'modern spiritualism' in late modernity and traditional or medieval spiritualism.

Internet and social media (frequency $=7$ ): The usage of internet and social media, including Facebook, was important among some of my informants who valued 'spiritual sensation' (hess-e ma'anavi). This was because an individual had more options to pursue his or her own personal desire in terms of what they considered as 'Islamic' in the form of film, documentary, an 'Islamic' figure's homepage, sermons or a recorded festival. They were also described as 'useful tools' for communication purposes.

a. '[In addition to TV and radio], the internet is also an effective and accessible mass medium in our time and its religious materials are more colorful. For example, our group is active on Facebook and other mass communication apps. We utilize the internet for informing people about our programs or disseminating them. Even those who had already been attending the group's programs and can no longer do so for some reason are now able to follow our programs virtually.' (A 26-year-old male student, who was active in the organization of a so-called 'Mourning Group' (hey'at-e azadari) in his local area.) 
b. 'Since I spend a lot of my time on the internet, I read many things that are disseminated there. For example, I follow the page of a cleric on Facebook, reading his work or watching the videos he disseminates. He does not want to show off. He tries to promote a spiritual Islam by telling the truth. His speeches do not serve the interests of a special group [of clerics] or class. I like such people.' (An educated 23-year-old man who was an active user of internet.)

c. '[Satellite] TV and internet have a completely global role. For example, an individual who lives in Paris can also follow all these [religious] ceremonies easily via [satellite] TV or the internet and vice versa. Of course, if the internet carries our national religious characters, they would certainly be more effective than $T V$. This is because TV has limits but internet has a global and interactive feature that is more effective than TV.' (An 18-year-old male student.)

$T V$ and radio: In contrast to the internet and social media, views on the usage of TV and radio for 'Islamic' purposes were divided. Thus, in addition to the internet and social media, TV and radio has also contributed to the diversification, subjectivization and individualization of 'Islam'. As we see below, my informants' reflections of what counts as 'Islam' as broadcast from State TV and radio are not the same:

(i) 'Positive and influential' (Frequency = 11): These informants did not appear to be critical of State-provided programs, especially those broadcast from TV. They enjoyed watching 'Islamic' festivals or ceremonies, although they preferred to physically attend their favorite ceremonies in person and to be a part of a particular event.

(a) 'I would rather satisfy my [religious] emotions by physically attending such ceremonies. However, if the conditions are not there for me, I utilize programs broadcast from radio and TV.' (A 55-year-old woman from a rural background.)

(b) '...TV has an effective role [in the transmission of religious emotions and experiences]. You see that the TV takes a completely religious form during the first ten days of Moharram. Perhaps if this did not happen, we would not have such religious feelings. In addition to its propaganda mission, it has an informative role too. This certainly has an impact on audiences.' (An 18-year-old male student.)

(c) '... [Mass media] is very very effective. They remind us of religion when we forget it. Or they sometimes show an event in such a way that we get provoked. They flip us if we are on our own ... Otherwise, these [religious] matters become less colorful and, in my view, gradually disappear. [Having said this] it depends on my state at a certain point whether to physically attend a ceremony and which one to attend or to stay at home and watch a TV program.' (An educated 25-year-old woman.)

(ii) 'Negative and/or uninfluential' (Frequency = 10): These informants were unconditionally critical of any 'religious' program broadcast from State media, including TV and radio. They opposed the alleged 'political agenda' behind these programs.

(a) 'Mass media is effective ..., especially in countries, such as Iran, where there are no [official] private channels. Programs are broadcast with the authorization of the government... Therefore, they easily gain what they want. For example, compare the news in Iran with Turkey. They are fundamentally different from each other. So are the matters related to religion. The government will not allow an intellectual, like Dr Soroush, to come on to say something different from what the religious authority desires ... For example, the series of 'Mokhtarnameh' that the TV broadcast was very different from the book. I do not have a positive view of the religious programs on TV in Iran where power is in the hands of a religious government. By propaganda and TV, they manipulate the nation's thoughts in their own [political] interests.' (A 23-year-old male student.)

(b) '... I do not watch programs that try to instigate crying. I immediately change the channel. I would like to watch programs that contribute to my knowledge ... For example, if four, out of five, 
channels show religious programs in the night of Ashura and say, for example, they show [Yazid, the Umayyad caliph] cut [Abulfazl, Hussain's brother's] hands ... and do not say why they did so, I watch the fifth channel that is, for example, a documentary about nature ... ' (An educated 24-year-old woman.)

(c) I think that I devote three quarters or more of my life for expressing religious feelings. This is because we have Fourteen Innocents (chahardah ma'asoum) [i.e., twelve Imams plus the Prophet and his daughter Fatemeh] and two [Islamic] months of Muharram and Safar as well as the martyrdom of the children of our country [implying the Iraq-Iran war] and other countries [referring to the Middle East] ... which has taken place throughout each year. In every ceremony whether happy (shadi) [referring to Imams' birthdays] or mourning ('aza), crying is on the agenda. Whenever we turn on the TV, a mourning ceremony is on or a film is shown on war and the martyrdom of our children. All this has made our youth loath war and the majority of them avoid Islamic Republic TV. This is because it shows news of the dead, war, blood and crying. Our children hate crying and sorrow. It is no different on local TV.' (A 50-year-old with a general education.)

(iii) 'Both positive and negative or partially influential' (Frequency $=7$ ): These informants conditionally approved some such programs, but not all of them. For them, some programs can be so 'negative' that could even 'put you off any religious belief'. These informants watched such programs only if they were not able to physically attend 'Islamic' ceremonies.

(a) 'Mass media is very effective in encouraging or discouraging individuals to express their religious emotions. They have both positive and negative roles. I try to be a part of the [religious] ceremony itself as much as I can.' (An educated 45-year-old man.)

(b) 'If [programs] are not biased and delivered in the right [non-ideological] way, they will be useful. Otherwise, they will cause people to escape religion ... ' (An educated 48-year-old man.)

(c) 'I may say that they [mass media] are effective forty per cent of the time. They may broadcast something from the religious channel that I do not like. At the end of the day, I am 33 years old and I know what I like about these programs and what I do not ... ' (An educated 33-year-old woman.)

Two, out of thirty, informants had no preference on whether to use State-provided mass media or to physically attend the festivals in person. For them, it depended on their feeling at that particular time.

\section{The 'Shi'ite Requiem' ('Maddahi') and Language}

This aspect of research focuses on the question of how different and diverse my informants, who are from various social backgrounds, 'construct' the definition of the 'Shi'ite requiem' and describe change (and continuity) in the 'religious' language of Shi' ite festivals, especially requiem lyrics (nouheh) during Tasu'a and Ashura. It was interesting that nearly all of my informants confirmed changes in the mood and content of these 'Shi'ite' songs, which distinguished them from those of the 'revolutionary' ('Islamism') as well as, the pre-revolutionary era ('Islam'). In both revolutionary and pre-revolutionary eras, all musical instruments, as 'religiously'-forbidden, were avoided. Contemporary 'Shi' ite' rituals have not only reconsidered the 'prohibition' of musical instruments but also attempt to convert the content and tune of requiems so that they are closer to 'non-religious' songs that are theoretically 'prohibited' in 'Islamic', including 'Shi'ite', jurisprudence or shari' $a$ as symbols of 'moral corruption'. For my informants, the reason behind this is that festival organizers would like to attract the attention and participation of the youth at their 'religious' ceremonies. It is interesting that, as far as I am aware, no Shi'ite jurist (fogaha), whether traditional or political (including the Islamic Leader himself), has yet objected to this. As we will see below, such changes have also contributed to the further fragmentation of 'mourning collectivities' (hey'at-haye azadari) and the individualization of 'religion' in the contemporary Iranian societal context. Indeed, responses to change in 'Shi'ite' requiems have taken various contextualized and subjectivized forms: 
(i) 'Shi' ite Requiem' as 'knowledge' (Frequency =6): There is a considerable trend among Iranian youth or the second generation after the revolution in questioning the emotional aspects of 'Shi'ite' festivals, particularly their crying segments. These individuals are more concerned with the 'reason' aspects of these festivities than its emotional aspects; e.g., why Hussain 'chose' death if he knew that it was going to happen? What was his message? Or did he really choose death? To what extent are the current narratives authentic? These questions go beyond the traditional simple answer of: 'he sacrificed himself in order to save Islam'.

(a) 'I would rather know about their [Imams' or the Prophet's] lifestyles, conduct, beliefs, how they treated ordinary people, advices that they gave about the treatment of friends and foes... It is not enough to listen to their hardships and cry for them. I would rather know what really happened at that time. I do not like exaggerations ... Today's requiems are similar to popular songs and they often ruin your religious feeling if you had one [to begin with].' (An educated 25-year-old woman.)

(b) 'The meanings of requiem lyrics are more important than their tune or how they are sung ... ' (An educated 27-year-old man.)

(c) 'The lyrics of today's requiems are not similar to those of the past. They have lost their previous forms and contents, although I know which ones to choose and which ones to avoid [implying I will choose whichever I like] ... It would be useful if there was a university course in this regard to teach people how to perform a religious requiem academically.' (An 18-year-old male student.)

(d) 'What I hear from a [religious] singer (maddah) must correspond to my own personal beliefs. If this is not the case, his requiem will have no effect on me... They keep mentioning different names in their songs, such as Sakineh. If I do not know who Sakineh is, what do you expect me to do? It would be difficult for me to cry for such a person ... ' (An educated 33-year-old woman.)

(e) 'I have lost the religious feeling and beliefs of society partly because of the nonsense that 'maddahan' [the performers] present to us. Is it important that Imam Hussain's eyes were big or his body strong? When I hear these things, I become disgusted of any religious person or religion ... I am a living example of the impact of such meaningless things on human beings ... ' (A 26-year-old female student.)

(ii) 'Requiem' as 'emotions' (Frequency = 4): Unlike the above-mentioned individuals, these informants highlight the 'true' religious sensations of these festivals which were common mainly during the pre-revolutionary era. Therefore, for them, the state of sorrowness and sadness in these mourning festivals are vital.

(a) '... The traditional requiems (nouheh-ha) contained sorrowness and sadness, but these [contemporary requiems] are like popular [non-religious] music. They [traditional or pre-revolutionary ones] were better. They were mourning festivals in real terms, but nowadays they shout 'Hussain, Hussain ... ' and hit their chest, but they are fakes [he meant that they do not believe in what they are saying]. Instead of giving you a religious sensation, mourning like this makes you mad and think that Imam Hussain deserves more than this ... ' (A 54-year-old with a primary education background.)

(b) '... Today's requiems no longer give me any religious sensation. They are normal [non-religious] songs. The previous [traditional] ones were full of sorrowness and affected my soul and mind (rouh va ravan). This is why I like them ... Today's requiems are talking about, for example, Imam's beautiful eyes and eyebrows ... What have I got to do with their eyes and eyebrows?' (A 29-year-old woman with a general education.)

(c) '... It is important that the [religious] singer (maddah) becomes attentive and enthusiastic in describing what happened in the [religious] stories ... This makes me so attracted to his sayings that I could hardly forget those stories.' (A 45-year-old woman with primary education.) 
(iii) 'Requiem' as 'spirituality' (Frequency =6): These forms of Shi'ite requiems literally emphasize the 'spiritual' aspects of 'Shi'ite' festivals in a way in which they are 'genuine' and 'far from formalism and duplicity' (ria va tazahor).

(a) 'Requiems are of little effect for me [due to their emotional aspects]. If you believe in God by following your heart and wisdom, it would be more effective and sensible.' (An educated 30-year-old man.)

(b) 'The meanings and content of the lyrics are more important to me. When a [religious] singer (maddah) sings nonsensical poems, I automatically feel repulsed by religion (din va madhab) ... Today's requiems do not transfer to me the degree of spirituality that I need (bar-e ma'anavi-e lazem) ... ' (An educated 25-year-old woman.)

(c) '... I try to choose festivities from which I can receive the degree of spirituality that I require (bar-e ma'anavi ke lazem daram). Spirituality usually transfers with meaningful lyrics ... I would rather listen to requiems that are calm and spiritual.' (An educated 23-year-old man.)

(d) 'We need to follow our heart to God. [In this way], we do not even need lyrics to be sung by a [religious] singer, who might not even believe in what he is saying himself.' (An educated 45-year-old man.)

(iv) 'Requiem' as 'art' (Frequency = 5): In contrast to the above-mentioned forms, which describe changes in requiem negatively, some of my informants conditionally viewed the recent developments in the phenomenon of 'requiem' as positive. For them, the 'artistic' aspects of these requiems were attractive. Due to the significant role of art in the subjectivization of 'Islam' in the Iranian context, the impact of art on 'Shi'ite' festivities, in general, will be discussed separately below.

(a) 'Art, in general, plays a prominent role in [religious] festivities. Certain poems, paintings, calligraphies, photos and so forth that are related to 'religion' have a great impact [on my religious sensations]. I become influenced as soon as I see them and start to think about these pieces of art and their relation to religion. I also praise the director of the 'Mokhtarnameh' series. It was influential ... I do not like the [traditional] Ta'azieh (shabih-khani) and things like that.' (An educated 24-year-old woman.)

(b) 'I would like to listen to calm and cool musical requiems (nouhehs) if they are not accompanied with stamping of the feet on the ground (koubidan-e pa bar zamin)'. (An educated 25-year-old woman.)

(c) 'I do not like prayers that I do not understand. However, if a [religious] singer (maddah) sings them with a nice voice, I will get influenced.' (A 27-year-old female student.)

(d) 'The foundation of requiems are lyrics and words and the ways in which they are expressed. Of course, rhythm and music are so important that without them the words would not be able to bring about the desired effect.' (An educated 26-year-old man.)

(v) 'Requiem' as 'global Islamism' (frequency =1): There was only one informant who thought that Shi'ite festivities are good instruments for converting the world towards the interests of Iranian Shi'ism or 'Islamism': 'If the language of requiems is clear and understandable, it will be excellent. It will attract many audiences. In addition, if they are presented in epic and non-superstitious ways, they will surely be more enjoyable. The advantage of [expressing requiems with] lyrics and words is that if they are translated to other nations' languages, real Islam will be known and will govern the world.' (An educated 45-year-old man.)

(vi) 'Requiem' as 'language' and culture (Frequency =13): Many of my informants preferred the requiems to be presented in their local language, i.e., Azarian Turkic, rather than Persian or Arabic. They did so not necessarily out of ethnic nationalist desires, which was the case for a few informants, but mainly because of the discourse with which they had grown up. 
(a) 'Of course, I would rather listen [to requiems] in my own language. I relate to them when it is in [Azarian] Turkic.' (A 54-year-old man.)

(b) 'Well, our religion has a direct relationship with the Arabic language. Its impact is clear in every festivity ... [However] Iranians have also produced many interesting requiems in their own local languages ... I believe that religious sensations are different in each language ... I would not mind listening to a requiem in the Persian language ... but at that particular moment, I would like to listen to it in my own language in order to internalize it.' (An 18-year-old student.)

(c) '... I am not biased towards other languages. But the poetic structure of [Azarian] Turkic music in requiems are Bayat [melody], which is different from other languages. It is called 'Okhshama'. I really enjoy it ... ' (A 26-year-old male student.)

Indeed, the vast diversity of the conceptualization of 'Shi'ite requiems', as demonstrated above, is indicative of a dramatic shift from traditional religious festivities to a 'modern' one, which is far from the 'religious' requirement of the organized Islam practiced before.

\section{The 'Construction' of 'Art' and 'Music'}

The world of 'art', in general, has always been separate from that of 'religion' in both pre- and post-revolutionary Iran, with the exception of some forms of art, which mainly appeared in architecture and calligraphy, that were called 'Islamic art'. According to shari'a, reflected whether in the form of 'Islam' or 'Islamism', some aspects of art are religiously forbidden and should be avoided; music is one of them. Playing some musical instruments, like a certain percussion dayereh, was described by the ulama as 'slapping the face of Fatemeh, the Prophet's daughter' in the pre-revolutionary period. Despite this, the majority of Iranians enjoyed listening to music or playing it. However, they considered this a part of the 'non-religious' aspect of their life, which they strongly distinguished from 'religious' requirements. That is, the social phenomenon of 'music' strictly divided the definition of 'Islam' from 'non-Islam'. For this very reason, all kinds of music were banned in public in the post-revolutionary era until Ayatollah Khomeini issued a religious decree ( $f a t v a)$ allowing some forms of music to play or listen to on the condition that they are played for 'revolutionary' and 'epic' purposes—not for 'gratifying' purposes that are concomitant with 'moral corruption'. This 'revolutionary' music was called 'soroud', instead of 'musiqi' or 'taraneh'. However, so-called 'non-religious' music gradually re-entered ordinary people's lives, although State TV and other elements of mass media are still restricted to broadcast 'soroud' and to avoid showing any images of music performance on TV. In the fourth decade of the Islamic Republic, as we saw above, it seems that 'music' has entered not only 'non-religious' aspects of people's life, but also the domain of 'religion' itself through the use of flutes and drums as well as a change in the form and content of requiems in 'religious' festivals. Moreover, the name of 'music' (musiqi) is not considered as dirty and 'sinful' as before. Indeed, neither of my informants used the term 'soroud' for 'music'. Nor did the informants avoid listening to 'music' on grounds of it being 'prohibited' by shari'a. 'Music' is not considered a 'taboo' and there is no longer such a divide between 'music' and 'religion', although people may still be aware of its prohibition in shari'a. This has led to many consequences and has furthered the diversification and individualization of 'Islam'.

(i) 'Music' as part of 'religion' (Frequency = 16): Some of my informants used 'music' in two different ways: 'religious' and 'non-religious'. The categorization of deeply Shi'ite 'requiems' or 'nouhas' as part of religiously-prohibited 'music' may be considered a sign of 'disenchantment of the world' and a new form of 'spiritualism', which is consistent with 'late-modernity' or 'post-modernity'. Indeed, some of my informants considered 'music', specifically 'calm' ones, as part of their subjective 'spiritual' developments too.

(a) 'Music and art embrace all aspects of our life [religious or non-religious]. When we go to a mosque or Hussainiyeh, art is the first thing that we confront ... if music was not important, 'adhan' [call for pray] would not have been performed in a musical way.' (A 26-year-old female student.) 
(b) 'Music has a lot of impact on [religious] singing (maddahi), but many of the singers (maddahan) are illiterate about music and just imitate other people's work. In my view, music has been oppressed [by the government], but we can use it more and in a better way. With the development of an academic study of the art of music, music can surely play a better and deeper role in our religious sensation.' (A 26-year-old male student.)

(c) 'Music has a lot of applications to [religious] singing (maddahi and movloud-khani). Still many singers are illiterate in music ... You may classify music in terms of religious and non-religious. [However] both of them contribute to human souls and spirituality, but in different ways.' (An educated 45-year-old man with a degree in Islamic Jurisprudence.)

(d) 'I listen to 'nouhehs' [religious] and music [non-religious] that correspond to my heart. I listen [to them] again and again ... I do not unfortunately have much knowledge of music, but I am really keen to learn more about it.' (An 18-year-old female student.)

(e) 'Art has a great impact on my [spiritual] thoughts and feelings ... I may even be influenced with the wordless music of Beethoven.' (An educated 24-year-old woman.)

(f) '[For me] religious ceremonies and gatherings are kinds of art, carnival and celebration. [However] they are categorized into two kinds: some of them are sad, which we may call religious, and others that are not sad, which we may call non-religious. Depending on the conditions at that time, I like both of them.' (A 23-year-old male student.)

(ii) 'Music' as 'non-religion' (Frequency =12): For these informants, 'music' was a 'non-religious' part of their life. In other words, they mostly used 'non-religious music' in their everyday lives, but they wanted to listen to the 'religious nouhehs' on certain days, such as Ashura and Tasu'a. In their view, the latter was distinguished from the former. These informants may be conscious of the prohibition' of 'music' in shari'a but were not bothered by it. For them, 'non-religious' music could contribute to 'spiritualism' too.

(a) I am not interested in religious music and, in my view, it has no value. When I listen to it, it reminds me of my own problems, rather than the Imams. In my view, music has no place in religion ... The difference between religious and non-religious music is that the former is sad, and the latter is happy. When I listen to the latter, I become calm and happy. It is 'haram' (forbidden), but it is helpful for me.' (A 45-year-old woman.)

(b) 'It is not appropriate to mix music and dance with mourning commemorations all the time, whether they are related to Imams or ordinary people. However, I have no problem with music in ordinary [non-religious] ceremonies and parties. Music is part of our soul and existence. It makes you calm and relaxed. I need it [for this reason]. It can also contribute to your spirituality in a way in which nothing can, but I do not like dancing. I view dancing as a sign of women's slavery through which they provide happiness for men.' (A 50-year-old woman.)

(c) 'Religious music and art are specifically related to Imams and saints. Such art reminds us of them and makes us sad. Other [kind of] music is usually, but not always, happy [non-religious]. [Whatever kind they are] I can tell in general that individuals can gain the spiritual status they wish by listening to and using music, art and theatre. They are indeed very influential.' (An educated 25-year-old woman.)

(iii) 'Music' as 'destructive' (frequency = 1): There was only one, out of thirty, informant who described 'music' as destructive. Interestingly, he did not oppose it on the basis of the shari' $a$ or objectively: 'Dance and music have very temporary effects (asar-e lahze' $i$ ), [but] they have destructive effects on the unconscious part of the human [mind]. For example, they increase a sense of illusion and phantom. Therefore, I do not agree with the use of music and art in religious ceremonies a lot.' (An educated 27-year-old man.) 
It was interesting that, despite the rather antagonistic policies of the Islamic Republic towards art in general, there was also a growing interest in other arts, such as drawing, film and dance, among some of my informants.

\section{8. 'Islamic' Architecture}

In order to identify and understand any possible correlation between my informants' 'religious' sensation and architecture, they were asked whether a building's architecture was effective in their selection of attendance in that venue. Only two, out of thirty, informants described 'architecture' as uninfluential in absolute terms. The rest of my informants confirmed that a 'religious' architecture was important for experiencing an 'Islamic' sensation or 'spirituality', although it was not described as the only factor.

(i) 'Spirituality' (frequency = 19): Nineteen, out of thirty, informants associated 'Islamic architecture' with 'spirituality' in three different forms:

(a) 'Simplicity': Perhaps under the influence of 'Sufism', these informants loathed an 'aristocratic Islam' and its manifestations in any form, including architecture. $($ Frequency $=10)$

- ' '... When I am attending a [religious] venue that has a lot of luxuries, I do not usually feel relaxed and calm (ehsas aramesh) and my spiritual feeling (hess-e ma'anaviam) vanishes.' (An educated 25-year-old woman.)

- 'I would rather not attend a venue that is too sumptuous. But if it has style and I feel that I could have a spiritual experience there, I like to go there.' (An educated 23-year-old woman.)

- 'A religious sensation could occur in any venue and time... However, if we consider the simple life of the Prophet, it did not involve exorbitant expenses. The Prophet was the leader of the poor and never pursued luxuries. This differentiates the Prophet's Islam from that of Saudi Arabia's rulers.' (An educated 48-year-old man.)

(b) 'Old and historical buildings' (Frequency $=4$ ): These informants associated 'spiritualism' with historical buildings that avoided any of the glamorous aspects of today's world.

- $\quad$ 'The older the religious buildings are, the more spiritual and attractive they are.' (An educated 45-year-old man.)

- I I Im personally attracted to religious buildings with an old architecture, although the quality of ceremonies is more important. This is because I feel that they have been built with more sincerity and genuineness.' (A 25-year-old female student.)

(c) 'Luminous and colorful buildings' (Frequency = 5): For these informants, the brighter and more colorful the buildings are, the more effective they are in inducing 'spiritual' feelings.

- $\quad$ 'I would like to choose a [religious] venue that is luminous and lucid. I feel that the more luminous it is, the more spiritual it is ... It need not necessary be luxurious. It can also be a simple place... [Of course] luminosity does not create spirituality in me. Spirituality is something related to my heart and is an inner property. The right architecture for me may increase my sense of spirituality.' (An 18-year-old pupil.)

- 'Spirituality is a personal matter. It is related to your heart. However, if I am situated in a venue that is more colorful, stylish and aromatic, I would not mind to stay there longer.' (A 54-year-old man with a primary education.)

(ii) 'Identity' (frequency = 2): For two informants the 'Islamic' identity of buildings in terms of their architecture was important. 
- II am in favor of positive traditionalism in architecture... The more we distance ourselves from our own customs and culture, the poorer we become in terms of thoughts, beliefs and culture. Our religious identity becomes less colorful too.' (An educated 26-year-old man.)

- 'The architecture of a religious building should correspond to Muslims' lifestyles ... The geometric style of Islamic architecture subtilizes and refines my soul.' (An educated 27-year-old man.)

(iii) 'Equality' (frequency = 1): For one of my informants, an observation of gender equality in the 'religious architecture' of a building was crucial: ' ... The old mosques were big. I like their entrances, minarets and domes. I like the pools in the middle of their gardens. It relaxes me, like my grandmother's house. I like the trees in their gardens too. [However] I do not like their discriminatory separate entrance doors for males and females. While men use the main big entrance, women should enter the mosque through a small door in the corner ... Even inside the building, women have a smaller space than men ... This is not appropriate.' (A 27-year-old female student in architecture.)

(iv) 'Subtle architecture' (Frequency = 3): a few of my informants defined 'religious architecture' in terms of their greatness and perhaps luxuriousness.

- $\quad$ 'The very existence of a large and pretty mosque is indicative of the greatness of my religion ... I have seen some mosques in Spain and Turkey to which I was very attracted. Since then, I have been thinking about why we do not pay attention to our religious buildings.' (A 24-year-old woman with a degree in architecture.)

- $\quad$ 'I do not like buildings with poor architecture. In fact, when I see Imamzadehs with a poor and simple building, I feel sorry for the saint who is buried there and I become sad.' (A 45-year-old housewife.)

Again, the question of what counts as 'Islam' in association with 'architecture' differs among my informants ranging from 'simplicity' and 'non-luxurious' to 'luxurious'.

\section{Conclusions}

Inspired by Beckford's (1989; 2003) 'social constructionist' theoretical approach towards the meaning of 'religion', this research illustrates how the definition of 'Islam' has changed in the Iranian context during the last forty years. The largely non-ideological institutional 'Islam' in the pre-revolutionary era became highly political and remarkably organized around mosques throughout the country during the revolution of 1977-1979 and the early post-revolutionary era ('Islamism'). On the fortieth anniversary of the Islamic revolution, this research demonstrates that contemporary Iran is experiencing a different definition of 'Islam' that is associated with 'spirituality', as defined by Beckford (2003, pp. 71-72; 2019).

As the findings show, the 'sacred' has been 're-located', in Beckford's terms, from an organized and institutional 'Islam' during the pre- and the early post-revolutionary Iran to a profoundly 'fragmented', 'subjectivized' and 'individualized Islam' or 'spiritualism' in contemporary Iran. Such a 're-location' is easily visible across the various aspects of 'Shi'ite' everyday life, ranging from the 'diversification of "Islamic" venues' to 'Islamic architecture' in the Iranian context, as discussed above. Depending on my informants' age, gender, education, social status and class, and urban or rural birthplace, their experiences of 'spiritualized Islam' in various dimensions of everyday life has been 'constructed' in incredibly diverse forms. These forms not only go beyond the requirements of an institutional Islam, such as the objective obedience of shari' $a$ and Shi'ite authority, but also dangerously oppose these requirements in some cases, such as those of conceptualizations of the 'Imams' and 'music'.

In addition, this research illustrates that there have been correlations between the independent variables of age, gender, education, social class and birthplace, on the one hand, and the individualized 'spiritualistic Islam', on the other. The younger my informants were, the more they were susceptible to 'spiritualism'- while the average age for the people with inclinations towards spiritualism was around 30 , it was 36 for the people who were inclined more towards objectivized Islam. It was interesting that 
females had more tendency towards 'spiritualism' than men (10 males and 15 females vs. four males and one female), especially when they chose their private space, made pilgrimages to Imamzadehs or showed 'no preferences' about venues. That is, men were more inclined to attend mosques. This is consistent with the contemporary contexts of the United Kingdom, Greece, Portugal, Italy, Spain, France, Germany, the Netherlands, Mexico and Israel, where more women than men leave different traditional religions and join various spiritual movements (Fedele and Knibbe 2013; Fedele 2019). In terms of education, the informants with first degree education and above were more susceptible to subjectivized 'spiritualism', while those with a level of general education and below were more inclined to a rather 'objectivized Islam'. The lower their level of education, the lower their level of 'spiritualistic Islam' was. Furthermore, the informants who belonged to a lower social class and rural backgrounds had a lower level of 'individualized Islam' than those who belonged to (lower-)middle class and urban backgrounds. As Beckford (2003, p. 72) elaborates, this is perhaps because the societal conditions in 'late modernity', which are themselves exposed to global forces (such as satellite TV, internet, social media and migration), play a critical role in shaping these individualized forms and 're-drawing' the frontier between 'religion' and 'spirituality' through changes in social relationships and culture.

In this sense, contemporary Iranian 'spiritualized Islam' is differentiated from the type of 'spiritualism' that takes place within the frontiers of an institutional religion, whether 'Islam', such as 'Sufism', or other religions, such as the Christian 'spirituality' observed in Kendal in north-west England (Heelas and Woodhead 2005). For example, 'spiritualism' in the current Iranian context is distinguished from 'Sufism' in the sense that the latter has historically given special, if not the highest, status to 'Imams', especially the first Imam, as the 'awlia elahi' (divine figures), whilst the former may desacralize them as 'ordinary people' or even as 'violent' or 'cowardly' figures. Or, whilst the former does not restrict itself in terms of the types of 'music', 'Sufism' is conditional to a specific type of music that is associated with 'deep mediation'. Moreover, the link between body, beliefs and emotions is central for 'Sufism' in many social contexts from Asia to Africa, but there is no such essentiality in 'spiritualized Islam' in today's Iran. On the contrary, some of my informants distanced themselves from 'emotions'.

Iranian 'spiritualism' can also be distinguished from the Kendal project, according to which although 'spiritualism' in the context of north-west England (Kendal) takes a form of 'subjectivization', the majority of these 'subjectivized' and 'spiritual' people still consider themselves 'congregational members' who are 'remaining obedient to God, scripture and the church.' (Heelas and Woodhead 2005, p. 113). My informants might still believe in God and the Qur'an, but they showed little sign of 'obeying' Him in the sense of pursuing shari' $a$ and acquiring its knowledge by visiting mosques and listening to, let alone seeking advice from, 'religious' authority in the way in which it has been reported about Kendal or traditionally occurring during (pre-)revolutionary eras. As we have seen, some of them even went beyond Shi'ite particularism and the recognized boundaries of 'religious' figure by giving examples that are inclusive of all humanity, rather than Shi'ism. In addition, our informants did not identify themselves as part of any collectivity in the way that the people in Kendal did, i.e., 'congregational members'. Moreover, unlike the Kendal project (Heelas and Woodhead 2005, p. 11), this research does not differentiate between 'subjectivization' and 'individualization'. By both 'subjectivization' and 'individualization', I mean that Iranian Shi'ites pay more attention to their own individual and subjective desires, needs, wishes and consciousness than the formalist and collectivist requirements of 'political Islam' as well as those of the organized and institutionalized non-ideological 'Islam'. This meaning of 'individualization', associated with 'spiritualism', is fully consistent with Godazgar's (2007, p. 397) findings in relation to the definition of 'individualism' as a key element of 'consumerism' in the current context of Iran.

Finally, I conclude that Beckford's 'social constructionist' approach to 'spirituality', the 're-location of the sacred' and 'cultural turn' from institutional state 'religion' to individualistic 'spiritualism' under 
the forces of globalization and the societal conditions of theocracy is fully consistent with the findings of this research.

Funding: This research received no external funding.

Acknowledgments: I would like to thank James Spickard for reading a draft of this manuscript and making useful comments and suggestions.

Conflicts of Interest: The author declares no conflict of interest.

\section{References}

Abrahamian, Ervand. 1982. Iran Between Two Revolutions. Princeton and New Jersey: Princeton University Press. Algar, Hamid. 2011. Emam-e Jom'a. In Encyclopaedia Iranica. Edited by Ehsan Yarshater. New York: Encyclopaedia Iranica Foundation, vol. 8, Fasc. 4. pp. 386-91. Available online: http://www.iranicaonline.org/articles/ emam-e-joma (accessed on 17 December 2019).

Amid-Zanjani, Abbasali. 2012. Enqelab-i Eslami-i Iran: Elal, Masa'el va Nizam-i Siasi. In The Islamic Revolution of Iran: Causes, Issues and Political Order, 2nd ed. Qom: Daftar-i Nashr-i Ma'arif. First published 1392.

Arjomand, Said Amir. 1989. The Turban for the Crown: The Islamic Revolution in Iran. Oxford: Oxford University Press. Ansari, Ali. 2019. The FCO [Foreign and Commonwealth Office] archives and the Iranian Revolution. Paper presented at Workshop: Iranian Revolution at 40: Source Criticism and Perspectives, Institute of Iranian Studies, St Andrews, UK, May 31.

Asad, Talal. 1993. Genealogies of Religion: Discipline and Reasons of Power in Christianity and Islam. Baltimore and London: The Johns Hopkins University Press.

Ashraf, Ahmad. 1988. Bazaar-Mosque alliance: The social basis of revolts and revolutions. International Journal of Politics, Culture and Society 1: 538-67. [CrossRef]

Atkinson, Paul, and Amanda Coffey. 2001. Revisiting the relationship between participant observation and interviewing. In Handbook of Interview Research: Context and Method. Edited by Jaber F. Gubrium and James A. Holstein. London: Sage Publications, pp. 801-14.

Beckford, James A. 1989. Religion and Advanced Industrial Society. London: Unwin-Hyman.

Beckford, James A. 2003. Social Theory and Religion. Cambridge: Cambridge University Press.

Beckford, James A., and University of Warwick, Coventry, UK. 2019. Personal communication via email.

Burns, Robert B. 2000. Introduction to Research Methods, 4th ed. London: Sage Publications.

Corbetta, Piergiorgio. 2003. Social Research: Theory, Methods and Techniques. Translated by Bernard Patrick. London, Thousand Oaks and New Delhi: Sage Publications.

Darlington, Yvonne, and Dorothy Scott. 2002. Qualitative Research in Practice: Stories from the Field. Buckingham and Philadelphia: Open University Press.

Eisenstadt, Shmuel Noah. 2003. Comparative Civilizations and Multiple Modernities. Leiden and Boston: Brill.

Emery, Christian. 2013. United States Iran policy 1979-1980: The anatomy and legacy of American diplomacy. Diplomacy and Statecraft 24: 619-39. [CrossRef]

Fedele, Anna. 2019. Religion, spirituality, secularism and gender at the Marian Shrine of Fatima. Paper presented at 35th ISSR Conference titled the Politics of Religion and Spirituality, Barcelona, Spain, July 9-12.

Fedele, Anna, and Kim Knibbe, eds. 2013. Gender and Power in Contemporary Spirituality. New York and London: Routledge.

Foltz, Richard C. 2004. Spirituality in the Land of the Noble: How Iran Shaped World Religions. Oxford: Oneworld Publications.

Foucault, Michel. 1972. The Archaeology of Knowledge and the Discourse on Language. Translated by Alan Mark Sheridan-Smith. New York: Pantheon Books.

Foucault, Michel. 1978. What are the Iranians dreaming about? Le Nouvel Observateur, October 16-22.

Georgakopoulou, Alexandra, and Dionsis Goutsos. 2004. Discourse Analysis: An Introduction, 2nd ed. Edinburgh: Edinburgh University Press.

Godazgar, Hossein. 2000. Motale'ye tatbiqi-e ta'rif-e hoviyyat-e melli az didgah-e Dr Ali Shariati va jomhuri-e eslami-e Iran. In Dr Ali Shari'ati. Edited by Javad Mizban. The comparative study of the definition of 'national identity' between Dr A. Shariati and the Islamic Republic of Iran. Mashad: Mashad Ferdowsi University Press, vol. 2, pp. 369-95. 
Godazgar, Hossein. 2007. Islam versus consumerism and post-modernism in the context of Iran. Social Compass 54: 389-418. [CrossRef]

Godazgar, Hossein. 2008. The Impact of Religious Factors on Educational Change in Iran: Islam in Policy and Islam in Practice. New York, Ontario and Lampeter: The Edwin Mellen Press.

Gray, David E. 2014. Doing Research in the Real World, 3rd ed. London: Sage Publications.

Halliday, Fred. 1999. Revolution and World Politics. London: Mcmillan.

Heelas, Paul, and Linda Woodhead. 2005. The Spiritual Revolution: Why Religion is Giving Way to Spirituality? Oxford: Blackwell Publishing.

Johnstone, Barbara. 2002. Discourse Analysis. Oxford: Blackwell Publishing.

Keddie, Nikki. 1983. The Iranian revolution in comparative perspective. American Historical Review 88: 579-98. [CrossRef]

Khatami, Ahmad. 2019. Ahmad Khatami: Rasaneh-ha az Khalvat Shodan-I Namaz Jum'ah Khoshhal Nabashand. [Ahmad Khatami: Media Are Not to Be Happy for the Emptiness of Friday Prayer]. Available online: https://www.dw.com/fa-ir/iran/a-49760966 (accessed on 27 July 2019).

Kvale, Steinar, and Svend Brinkmann. 2009. Interviews: Learning the Craft of Qualitative Research Interviewing. London: Sage Publications.

May, Tim. 2011. Social Research: Issues, Methods and Process, 4th ed. Croydon and New York: Open University Press. Milani, Abbas. 2011. The Shah. New York: Palgrave Macmillan.

Ritchie, Jane, Jane Lewis, and Gillian Elam. 2003. Designing and selecting samples. In Qualitative Research Practice: A Guide for Social Science Students and Researchers. Edited by Jane Ritchie and Jane Lewis. London: Sage Publications, pp. 77-108.

Said, Edward W. 1980. Iran and the press: Whose holy war? Colombia Journalism Review 18: 23-33.

Salam-i No. 2019. Chera in rouz-ha az namaz-i jum'ah istiqbal nemisahavad? Imam jum'ah-haei ke shabihiI Taliqani Nistand: Namaz-i jum'ah chehel sal-I ba'ad' [Why Are not Friday Prayers Welcomed Nowadays? Imam Jum'ahs Who Do not Look Like Taliqani: Friday Prayer after Forty Years. Available online: https: //salamno.ir/detail/24133698 (accessed on 29 July 2019).

Van Dijk, Teun A. 2001. Critical Discourse Analysis. In The Handbook of Discourse Analysis. Edited by Deborah Schiffrin, Deborah Tannen and Heidi E. Hamilton. Oxford: Blackwell Publishing, pp. 352-71.

Volkov, Denis. 2019. The Russian analysis of the Revolution. Paper presented at Workshop: Iranian Revolution at 40: Source Criticism and Perspectives, Institute of Iranian Studies, St Andrews, UK, May 31. 
Article

\title{
Beyond Narcissism: Towards an Analysis of the Public, Political and Collective Forms of Contemporary Spirituality
}

\author{
Anna Clot-Garrell ${ }^{1, *}$ and Mar Griera ${ }^{2}$ \\ 1 Department of Sociology, Universitat de Barcelona, 08007 Barcelona, Spain \\ 2 Department of Sociology, Universitat Autònoma de Barcelona, 08193 Bellaterra, Spain; \\ mariadelmar.griera@uab.cat \\ * Correspondence: annaclotgarrell@ub.edu
}

Received: 5 September 2019; Accepted: 12 October 2019; Published: 16 October 2019

\begin{abstract}
Holistic spirituality has often been characterized by academic literature as belonging to the private sphere, articulated through the market and anchored in the growth of narcissistic individualism. However, recent empirical evidence and theoretical developments suggest a more complex picture. Drawing on the analysis and comparison of two empirical cases-the organization of collective meditations in public spaces and the teaching of yoga in prisons by holistic volunteers -we explore the rise of social engagement initiatives, aiming to transform society through the promotion and use of holistic techniques. Our main conclusions revolve around four main issues (a) the move of holistic spirituality from the private to the public sphere and the increasing public resonance with (and acceptance of) the contemporary holistic milieu, (b) the emergence of an holistic imaginary of social change anchored in ethics of reciprocity and responsibility, (c) the role of the body as a central locus of resistance and social transformation and (d) the articulation of new forms of individualism that enable to make self-realization compatible with social and political commitment.
\end{abstract}

Keywords: religion; power; resistance; social theory; holistic spirituality

\section{Introduction}

Stereotypical portraits of holistic spirituality have usually depicted its followers as narcissistic individuals focused on nurturing their own spiritual selves through the consumption of spiritual practices and commodities. Most of the sociological literature has pictured holistic spirituality in similar terms, describing it as articulated through the market (Liptoviesky 1983; Roof 1993), anchored in the contemporary growth of individualism and subjectivism (Beck 2010; Lasch 1979; Taylor 2007) and confined to the private sphere (Luckmann 1967, 1990). Holistic spirituality has thus been mainly understood as reinforcing an ideology of passivity and possessing an 'elective affinity' (Weber 1922) with the spread and deepening of neoliberalism (Carrette and King 2004; Illouz 2008). However, in recent years, this conceptualization has been challenged in numerous respects and a more nuanced image of holistic spirituality has unfolded (Fedele and Knibbe 2012; Hedlund-de Witt 2011). New research projects have signalled the public dimension of holistic spirituality (Aupers and Houtman 2006), while others have shown the need to move beyond the understanding of holistic followers as passive agents of neoliberalism (Farias and Lalljee 2008; Höllinger 2004) and to explore instead the political commitment and engagement of mind-body-spirit practitioners (Berghuijs et al. 2013; Chandler 2008; Oh and Sarkisian 2011).

Our article contributes new insights to these present debates, by focusing on the analysis of social transformation initiatives born out of groups inspired and shaped by holistic spirituality principles and practices. The main aim is to explore the ways in which holistic spiritual actors engage in civic 
actions and how they explain and justify their activism. Drawing on an ethnographic study of two cases - the teaching of yoga in prisons and the organization of public meditations in streets and parks-we show that social actors are not only involved in these altruistic initiatives, but that a holistic worldview is at the core of their engagement since they use these holistic practices as means for social and political transformation.

The initial motivation for this article emerged amidst the fieldwork of two very different research projects. On the one hand, whilst conducting fieldwork on religion in prisons (Griera and Clot-Garrell 2015a, Griera 2017), we came across the popularization of yoga courses, taught by volunteers, in penitentiary centres in Catalonia (Griera and Clot-Garrell 2015b). On the other hand, whilst researching a project exploring expressions of religiosity in the public spaces of Barcelona, we became aware of the increasing diffusion of collective public meditations and mindfulness marches in the public spaces of other global cities, similarly aimed at promoting peace and social transformation (Griera et al. forthcoming).

Both cases attracted our interest since they seemed to contradict, or at least call into question, the classical representations in academic literature of the expression of holistic spirituality in three ways. Firstly, the main setting for the development of holistic spirituality practices was not the private but the public sphere-public institutions (prisons) and spaces (streets, squares and parks). Secondly, in the two cases the actors' main motivation was civic engagement for social justice rather than narcissistic self-fulfilment. Thirdly, both cases were not market-oriented but non-profit initiatives based on volunteerism. In the light of this evidence, we considered that the comparison of the two cases was able to facilitate more nuanced understandings of the characteristics and complexity of contemporary forms of holistic spirituality and its social implications for broader society.

The data presented and discussed in this article derives from these two projects. A qualitative methodology, combining different methods of data collection, was adopted in both projects. From 2013-2015, we undertook ethnographic research in three Catalan prisons combining participant observation of yoga courses, surveys of participants, in-depth interviews with inmates, yoga volunteers and prison staff, along with the collection of documentary material. From 2015-2018, we undertook participant observations in public holistic initiatives in Barcelona, in-depth interviews with the organizers, ethnographic interviews with participants, along with the collection of material through social networks. We have applied an "iterative strategy" (Bryman 2008) during data collection and analysis. The results presented and discussed in this paper are based on a systematic comparison of source materials from these two projects. This comparative analysis aims to detect patterns of similarity in the ways in which actors, inspired by holistic spirituality principles and practices, not only participate in initiatives for social transformation but also promote them.

The article is organized in three sections. The first contextualizes the rise of holistic spirituality in the Catalan context and synthetizes state of the art in scholarship addressing the relationships between holistic spiritualties and forms of social engagement. The next section introduces the two case studies by examination of their main characteristics, the actors and the rationales behind the social transformation initiatives promoted by holistic spirituality groups. The third section discusses the results by identifying the patterns of similarity between the two cases and identifying the three aspects that articulate the ways in which holistic spiritual actors engage with civic actions and promote projects aimed at social and political transformation. Finally, the fourth section concludes with analysis of the social, public and political dimensions of some current holistic spiritualities.

\section{Holistic Spirituality in Context: Theoretical and Methodological Considerations}

During the last twenty years, the rise of holistic spirituality has been documented in Barcelona and Catalonia (Griera 2002; Prat Carós 2012). The dynamics of secularization and pluralization have not only reshaped the traditional religious map — historically synonymous with a dominant Catholic culture-by enhancing the growth and visibility of religious minorities but also facilitated the proliferation of new spiritual repertoires and products transcending the different faith traditions present in the territory (Griera 2014). Holistic spiritualities, understood as those forms of body practice "that have as their goal 
the attainment of wholeness and wellbeing of 'body, mind, and spirit'" (Sointu and Linda 2008, p. 259) in their distinct, subjectivized and embodied forms, have become popularized and normalized among the population, as relevant studies in Europe and elsewhere have demonstrated (Ammerman 2010; Bender et al. 2013; Dawson 2007; Houtman and Aupers 2007; Knoblauch 2008).

While diverse spiritual products and practices have been mainly explored as manifestations of privatized forms and marketized articulations of the spiritual, the entanglements between, on the one hand, expressions of holistic spirituality and secular-public spaces and the relationship between forms of political commitment and social engagement, on the other, have remained underexplored. Nonetheless, some investigations have started to address these issues.

Recent studies have begun to highlight that the emergence of the holistic milieu in public contexts often assumes a collective and usually altruistic form, particularly in public institutions (Becci 2018; Griera 2017; Griera and Clot-Garrell 2015b). Additionally, some research has also started to explore holistic spirituality's presence in open-air urban environments (Hegner and Margry 2016) and its relationship with political and social movements (Viotti and Funes 2015; Zwissler 2018). This silent proliferation of holistic spiritualities in public spaces is not only relevant due to its invisibility, which calls into question traditional articulations of the secular, the public and the religious (Fedele and Knibbe forthcoming), but also for the unique ways that its presence problematizes traditional assumptions in the field.

Beyond this public dimension, new empirical research, using quantitative and comparative methods, has also started to explore the relationship between holistic spiritualities, political ethics and social engagement, adding further complexity in the field-for example, Bellah et al. (1985) raise important questions concerning the ethical effects of holistic spirituality practitioners. Farias and Lalljee (2008) have examined the extent to which New Age ideas reinforce secular individualistic values. They showed that, while there were similarities between the individualism of New Agers and nonreligious people, the former defined themselves using a set of abstract holistic self-concepts that limited competitive goals and emphasized values of universalism. Similarly, Höllinger (2004) has shown that, in Austria, the young people classified as "New Agers" (10\%) by two representative Austrian surveys-the International Student Study 2001 and Austrian Youth Value Study 2000—reported a larger involvement in political and social activism than other students.

Other recent studies have more specifically addressed the social and political engagement of holistic followers, which is of particular relevance to our study. The work of Berghuijs et al. (2013), for instance, has underlined that, although the social involvement of holistic participants was lower than that of affiliated religious people, it is similar to that of secular groups and is marked by support for particular causes, such as environmental protection, peace or animal rights. In the same vein, Chandler (2008) has pointed that despite holistic spirituality is related to postmaterialist values, this does not mean that they are less socially and politically involved but only that they express their participation through different channels. In this regard, he states "autonomy and self-expression are not synonyms for negative freedom. By the same measure, the autonomous and self-expressive nature of contemporary 'New Age' does not make it de facto a selfish religion, even if it is a religion of the self (Chandler 2008, p. 252). Finally, the study of Oh and Sarkisian (2011) is also relevant because they examined the specific social involvement of people in the holistic milieu and demonstrated that they are not less socially engaged than the rest of the population. They have illustrated, moreover, that the level of engagement in voluntary associations and political groups strongly depends on their preferred type of holistic practice and the strength of their self-reported spirituality. In their study sample, they discovered that spirituality was more related to social involvement among practitioners of yoga and Art of Living than it was for practitioners of Dahn Yoga.

Our research benefits from these previous studies but also introduces one important shift. We focus specifically on the analysis of social transformation projects that are inspired and articulated by holistic spiritual principles and practices. In our research, we do not analyse the degree of social involvement of holistic followers in general but rather focus our attention on those followers that are reportedly 
committed to transforming the world through the use and spread of holistic practices. To foster a more complex understanding, we compare two different cases.

\section{Scenes and Actions: Holistic Spirituality in the Prison and on the Street}

This contextualization has prepared the ground for the specific characterization of the two social transformation initiatives promoted by the holistic spirituality groups under analysis: yoga practice in prisons and public meditations in the street. For each case, we analyse the profiles of the actors involved, their motivations and repertoires of action, along with the outcomes they expect from their social and political engagement, in order to facilitate their comparison.

\subsection{Holistic Spirituality in Prison}

Nowadays, almost all penitentiary institutions in Catalonia offer yoga classes for inmates, in addition to other spiritual practices such as meditation or reiki. This provision is not exclusive to Catalan prisons but represents a general trend identifiable in several countries ranging from Switzerland, to the United States, Mexico and India (Rucker 2005; Rabi Blolndel 2011, 2012; Bilderbeck et al. 2013). For three years, we have been following the organization of these courses, accompanying the teachers in their classes-and even shadowing the yoga teachers during training-in order to deepen our ethnographic understanding. Initially, the research was focused on exploring the impact of yoga in the inmates' lives and also the institutional opportunities-and constraints-associated with the organization of such an activity in the context of the prison (Griera 2017; Griera and Clot-Garrell 2015b). However, as the project was advancing, we started to become more interested in the characteristics and role of the yoga teachers themselves, and several questions emerged: why do these yoga teachers relinquish the comfort of the yoga studio to devote their free time and resources to teach yoga to inmates? How do they frame this social engagement and what do they expect to obtain from it? How does the image of the 'narcissistic New Ager' fit into this scene? Why is easier for penitentiary institutions to recruit volunteers to teach yoga than to teach theatre, philosophy or art?

In Catalonia, one of the main promoters of yoga in prison has been the non-profit organization WorldPrem. Although WorldPrem is not the only organization promoting yoga and holistic therapies in prisons, it holds a special agreement with the Justice Department of the Catalan Government and has coordinated yoga courses in prisons for several years. Under the auspices of WorldPrem, about thirty yoga teachers voluntarily delivered regular and free yoga courses in 2016. WorldPrem was founded in 2010 as the non-profit arm of a well-known international kundalini yoga organization in order to share the benefits of yoga with the socially excluded, including those with disabilities, sex workers, drug users and the incarcerated. The aim of the organization is defined by its founders as the promotion of social change through individual transformation. One of the members explained: "[ ... ] Prem is love. In Sanskrit, there are two words to define love: Prem, a love more unconditional, more global, the other is more affective. Then, World is world, unconditional love."

WorldPrem, in common with the increasing number of individual yoga volunteers and other associations than organize yoga courses in prison, do not receive funding for this activity. Yoga volunteers need to cover all their expenses. For prison staff, yoga is an activity that straddles sport, leisure, therapy and rehabilitation. Yoga is, thus, framed as a secular activity offered to all inmates, irrespective of their faith. In the prisons in which our fieldwork was conducted, we observed yoga to be very popular and there to be, in most of the institutions, a-usually long-waiting list of prospective participants. Most of the yoga courses follow the same format: typically, a weekly session lasting one and a half hours practiced by a group of up 25 inmates. However, in some cases, intensive courses-such as the 'yoga quarantine,' during which three hours per day of yoga is practiced over 40 days by a reduced group of inmates-are organized. We did our fieldwork in two different penitentiary settings: one male remand prison and one high security prison with both female and male penitentiary units. Contrary to general societal trends, within prisons, yoga is highly popular 
among men, which raises interesting concerns in relation to the construction of alternative forms of masculinity (Griera forthcoming).

The profile of yoga volunteers follows a similar pattern. Most volunteers are aged between 30 and 50, with a white middle-class urban background. Among our sample, we have identified a gender balance with a similar proportion of male and female teachers. Yoga volunteers are, mainly, accredited yoga instructors, but there are others who are still undergoing teacher training and for whom involvement in prison teaching is part of their training. Many of them belong to the kundalini ${ }^{1}$ yoga movement and-although they share with prison staff a secular framing of yoga-this style of yoga has a strong spiritual basis which finds expression in classes through, for example, the chanting of mantras or the development of specific kriyas. ${ }^{2}$ As one the volunteers explained: "yoga means union. That is, what I am doing to you, I am doing to myself and to the world because everything is one: this is yoga. In our yoga, you start with ek ong kar, the kundalini yoga base phrases and ek-kar, which means that everything is one." This spiritual tone can also be discerned in the discursive motifs that configurate the narratives detailing the social involvements of yoga teachers in prison.

Analysis of the volunteers' motivations to altruistically teach yoga in the prison setting reveals comparable discursive motifs. Most describe their social involvement in teaching yoga in prisons as an outpouring of gratitude and as a way to give back to society that which yoga has conferred upon their own lives. In the interviews, their own experience with yoga is depicted as self-transformative, as this yoga teacher expressed:

(... ) as part of my time, or part of what I dedicate myself, I give it to life and named it 'life,' 'existence' - everything that is God. For me, it is a gift living that experience [of yoga] so the minimum that I can do is to offer [yoga] as a gift. I also see it as a way to feed everything else [social change], as well as at an energy level. It's like that.

For most of the volunteers, yoga is not only a physical activity, but a practice that has opened a "path of self-discovery," an "alternation" process facilitating important changes in their lives and re-invigorating their biographies (Berger 1963, p. 68). Their involvement in the yoga milieu has been concurrent with the internalization of an "holistic theodicy," enabling them to understand themselves, their relationship to others and the wider world (Griera 2017). This personal experience is what moves them to bring yoga to prisons and to promote the idea that the adoption of yoga can be a crucial 'turning point' in the inmates' process of rehabilitation and transformation, in a similar way that it has been for them. One volunteer explained: "I see that I am helping them to wake up, to open their eyes to some things ... I am giving them an oasis of wellbeing, of peace, of light, of connection with themselves, within a desert and so establishing a strong life situation."

They consider that work with the body through yoga asanas (poses) is a plausible catalyst for personal transformation at the physiological, mental and spiritual levels. From this point of view, inmates are especially sensitive (or receptive) to opportunities for change: their suffering is interpreted in terms of karma and-making a conscious effort not to be judgmental—volunteers conceptualize yoga as an opportunity for redemption. They believe and state that beyond (and despite) physical imprisonment, there is a mental imprisonment which can be overcome, as this other volunteer narrated:

I try to provide them, remind them, that the strength they are looking for is within, that is, they have to wake up ... The philosophy of yoga is that power is in your hands, that is, it is yours and what you are looking for, through practice, is to connect more and more to that

1 Yogui Bhajan popularized modern Kundalini yoga during the seventies in the US. From there, it has been exported all over the world and it provides a combination of yoga asanas, tantric ideas and Sikh mantras. It is said to be the 'most spiritualized' form of contemporary yoga styles (Khalsa 1986; York 2004).

2 Kriya refers to a set of practices, mainly breath control techniques and exercises, that are practiced to achieve a specific outcome. The word is a Sanskrit term that means 'completed action.' See: https://www.yogapedia.com/definition/5022/kriya (last accessed: 15 August 2019). 
power, to really understand that it is there, that God is there, that you can do what you want with your life [and] that, if you are not doing it, it is because you have not managed to digest something of your past, or it is your way of seeing the world that leads you away from that.

Inmates' experiences of the harshness of prison life are considered not to represent an obstacle for personal and spiritual transformation but, on the contrary, to prove advantageous. Volunteers' narratives of hope are presented to the yoga class in order to help inmates to make sense of what Goffman (1961) defined as the major suffering of imprisonment-the feeling that your life has been paused and is meaningless. Prison becomes, then, re-interpreted as meaningful and as a space for personal and further social transformation. Volunteers firmly expect that individual changes will have a ripple effect on the inmates' complete lives-from their relationships with fellow inmates and family to society in general, as one of the volunteers narrated:

I have the feeling that I am doing what I have come to do, which is [to teach them] how to awaken awareness and help them at the same time. It's like a domino effect, right? I see that we are giving small inputs that generate changes in people and these changes are at the same time generating changes [in] the people that surround them. [It's like a domino effect that [operates] among all the people that are in that [the yoga and holistic spirituality milieu].

Nonetheless, the will to deliver yoga to prison extends beyond this personal stance and is framed as part of what is called "karma yoga," the kind of yoga that implies a social action and "doing good to the whole world and loving all beings." Therefore, teachers express their aims to have both an affect and effect on the prison's wider context (Engelke 2012). The will to bring yoga to prisons is articulated through a logic of gratitude and is, therefore, not very different from motivations for proselytism in other religious contexts. However, karma yoga is not only conceived as an altruistic task, underpinned by an assistential attempt to promote individual wellbeing in prisons, but is also described, through use of discursive motifs common to social movements, as a practice capable of nurturing wider social and political emancipatory projects. Indeed, some of the yoga volunteers conceive that the local and individual changes that yoga encourages may have global and collective impact:

We are thousands of millions, that is, we are very many people, each with their small parcel. It's [like a little garden, because it is what is being [created], or this [yoga] is supporting a paradigm shift that is taking place.

For the volunteers, therefore, yoga is not only an altruistic task but rather one that is framed by a broader project of social transformation-a process which the practice itself has the potential to initiate. However, yoga teachers are not totally unaware of the risk they incur of becoming instrumentalized by prison authorities in order to contribute to the disciplining of bodies and minds. They address this challenge by way of two assertions. On the one hand, they emphasize that calmness is not a synonym of passivity but instead might be a necessary precondition of the reflexively required if one is to resist and challenge the system. Volunteers intuit that, beyond the institution's perception of yoga as a free-cost activity that encourages tranquillity, there is a subversive and transformative dimension of their teaching. Behind the peacefulness that apparently facilitates disciplinary demands, volunteers explain how they encourage self-empowerment and resistance to the submission and docility promoted by prison authorities for the mechanical rule-following. They want to turn aggressiveness and violence into a positive force capable of generating individual changes by fostering self-esteem and self-consciousness. On the other hand, most of the volunteers link this self-transformation to the New Age's holistic motif, highlighting how social transformation is predicated upon personal transformation (Dawson 2007; Heelas 1996).

\subsection{Holistic Spirituality in the Streets}

Holistic spirituality encounters in public spaces are proliferating, but empirical research on those occurring in open-air contexts is scarce (Hegner and Margry 2016). While the focus has increasingly 
been drawn to forms of religious practice arising from different faith traditions, which are more visible, institutionalized and-sometimes-problematized (Becci et al. 2013, 2017; Burchardt and Griera 2019; Hjelm 2015); holistic expressions of spirituality are growing in the midst of public squares, streets or parks in a more unnoticed way and have received less attention. Since 2015, when the project on urban religious expressions was started in Barcelona, we identified that, beyond processions and festivities organized by formal religious communities, a wide range of holistic spirituality activities were informally and regularly taking place at the beach, public parks, avenues, streets and squares. Frequently, small groups use public environments for their practice; occasionally, massive events, which differ significantly from traditional spiritual festivals, are arranged (Becci and Grandjean 2018; Gauthier 2013) with social and political transformative intent. Why are these activities taking place outside the holistic setting? Why do holistic practitioners want to be visible? How do participants and organizers understand their social impact?

We have observed that-in addition to the weekly demonstrations for Free Tibet that take place in a central square of Barcelona and which have an exclusively political purpose-public meditations with an overtly spiritual tone, that encourage holistic practices as a vehicle for social and political action, have grown. These civic actions, which are not only collective and public but also have as their non-profit driven objective the promotion of holistic practice to effect social and political transformation, are the object of our attention.

In the case of Catalonia, these meditative civic actions have been mainly organized by groups and individuals informally linked to the Catalan Platform of Buddhist groups. ${ }^{3}$ Actually, most have been mainly promoted by Wake Up, an international association that gathers Buddhist and non-Buddhist people involved in the mindfulness practice inspired by the teachings of the Zen master Thich Nhat Hanh. Wake Up's mission is succinctly expressed as the pursuit of a social transformation through mindfulness practice. ${ }^{4}$ Invoking the figure of Thich Nhat Hanh as a peace activist in the Vietnam war, Wake Up frames their activities-particularly public events, such as meditative flash mobs in cities-in terms of "contributing to building a healthier and a more compassionate society." Nonetheless, there are also other organizations that, increasingly, promote public meditations within the civic arena. In Catalonia, for example, the public activity of the Catalan movement Conscious Country, which has encouraged recent public meditations in collaboration with different holistic and religious organizations, is especially noteworthy. This movement is a platform of different experts and associations, created between 2011-2015, with the aim of building a conscious nation by awaking the individual and collective consciousness, which not only results in inner peace but also has beneficial social consequences.

In our fieldwork, we have thus identified two modalities of holistic civic action promoted by these two organizations. Firstly, public seated meditations that are organized with a social and political objective, usually related to peacebuilding and non-violence (for instance, the 2011 public meditations, coordinated by Wake Up in Barcelona's squares in order to promote human rights in front of the Catalan Government and Barcelona City Council or the peace day commemorations of 2015). The Marathon of Silence, organized to alleviate the tensions in Catalans politics during autumn 2017, gathered together Brahama Kumaris and Zen Christians along with diverse holistic, Buddhist and mindfulness groups, to perform various public meditations in front of the Parliament in order to promote serenity, peace, tolerance and compassion.

3 The Catalan Platform of Buddhist groups (CCEB) was founded in 2007 in order to coordinate and create synergies between various associations and Buddhist centres of Catalonia and the Balearic Islands with the will to present Buddhism to-and represent Buddhism in—society. See: https://www.ccebudistes.org/es/origen-y-objetivos-de-la-cceb/(last accessed: 20th September 2019).

4 Mindfulness is a technique that represents a form of vipassana meditation aimed at consciously anchoring the mind in the present moment. Starting with a basic technique of breathing, it gradually develops into intentional awareness of one's bodily sensations, emotions and ultimately thoughts, in attempt to calm the mind (Arat 2017). 
A second type of holistic initiative, with a similar discursive motif, has proliferated recently: meditative marches. These marches resemble the religious processions which periodically occupy the central streets of the city, since Buddhist monks (from Thich Nhat Hanh's Plum Village monastery in France), dressed in their brown robes, lead the march; there is also a likeness to political demonstrations, apparent in the exhibiting, by marchers, of posters and signs. Some of these silent marches are organized once a year by Wake Up in order to direct 'collective energy' towards the goal of peace. However, there are also marches which have taken place in response to specific events. For instance, in 2017, after the terrorist attacks in Barcelona, Wake Up - along with other Buddhist groups and a Christian meditation movement in Barcelona-organized a massive silent march through the city streets in order to express solidarity with the victims, endorse peace-building and protest against violence. Likewise, in 2018, Conscious Country-along with several civic local associations, different religious communities and local peace activists—organized a silent march at the Arc de Triomf in which people dressed in white in order to promote peace.

Each of these different forms of public and collective meditation, in common with yoga teaching in prisons, are presented as secular pursuits, albeit acknowledging an intrinsic spiritual dimension. They are narrated, by their organizers and participants, in terms of promoting peace; that is, they are articulated as peaceful and silent acts, lacking any explicit religious purpose (even though most of the organizations involved are connected to traditional religions and the majority of participants either belong to, or are affiliated with, Buddhist or Christian meditation groups), as this Buddhist leader explained:

If what you are told is the need to be aware, you are aware. Even if you are not in any religion, then you support it while you can accept the things that it tells you. That's why it is good to unmark labels that [exist] already [and which are] in a way, obsolete and that is why also mindfulness that has emerged, which is the meditation of all life. The Satipatthana Sutta is from 2500 years ago [and] cannot be explained as it [was] explained before, as if it were a religion.

These two modalities of holistic civic action are both organized and designed as flash mobs. These gatherings, arranged through social media networks (such as Facebook, Twitter, Telegram or WhatsApp) are a fluid network of individuals—not necessarily known to each other, although they are usually actively involved in different mindfulness and Buddhist settings-who form into a tangible holistic community of practice for these events; although the profile of people participating in these events varies, certain commonalities can be identified. From our participant observations, we have identified that the ages of participants range from thirties to late sixties and determined that many are white middle-class women from an urban background.

A central feature of holistic civic action is that such communal expressions are closely entwined with the altruistic intent of participants. Such events are free of charge and supported by donations, as one the organizers and participants explained: "another issue of going out on the street is because we believe that this teaching [meditation] should be open to everyone, that is, everybody must be able to reach it." This openness, through which these two modalities of holistic civic action are motivated and justified, is not only explained in economic but also collective terms, as is evident in this organizer's remark: "we want to make serenity and calmness visible to the streets. We can no longer keep our spiritual commitment at home." There is a will to become visible, in order to create awareness about the possibility of acting differently at both the individual and collective levels. There is, thus, a form of 'conscious exhibitionism,' rooted in the belief that the mere disruptive presence of meditators in the street might create conditions for change by raising awareness among the population, as the promotion material of the Marathon of Silence explains:

In light of the tense situation that has been generated, it is advisable that serenity and interiority become visible on the street and especially in emblematic places. For this reason, a set of events, we call a Marathon of Shared Silence, is open to everyone. We meet ourselves 
without flags or emblems, above the noise of the words and the slogans that divide; people may say we are united in silence, in an attitude of internalization, meditation, prayer, visualization or projection of the future, according to their individual preference. People who are fasting for the same reason are welcome. We are convinced that a collective gesture, which is persistent, sprouting from the heart and fortified by the strength of thought that is well focused, will help overcome the spiral of confrontation.

Arising from the action repertoires of social movements, these public and collective dimensions (in common with those integral to the practice of karma yoga in prisons) are anchored in a spiritual tradition. Sometimes, the organizers, particularly those who are involved in Buddhism, claim the roots of such initiatives and identify with socially engaged Buddhism. For instance, Wake Up tactically evokes the figure of the Thich Nhat Hanh as either Zen Master or-especially during public meditations-as peace activist. As a Buddhist leader who regularly participates in seated meditations and silent marches explained, these individual and local dimensions of social and collective transformations are also observed in prison:

We are mobilizing for something, which is to convey to society the message that we are not selfish people that are at home doing our practice-although [this] is still basic and fundamental because the healing of the soul itself is also very important. If you are not healed, you cannot heal anyone, but this aspect of showing that we are here is also important: [it shows] that we are about to help, and we want to integrate ourselves into society at all levels. That is why these Thich Nhat Hanh walks transmit the expression of a different way of walking, a conscious way of walking and doing all things. Walking consciously is just like a metaphor [for] being conscious in our lives; we have values and we have to respect and take care of them. These values are solidarity and meditation. Mindfulness is also doing everything you do every day but consciously.

These initiatives are built upon the expectations of the performative material and spiritual power of meditation, as one of the organizers of the seated meditations during the Catalan political conflict stated, "We are convinced that a collective gesture of silence and focused thinking, which blossoms from the heart, will help to overcome the confrontational spiral." They all place a special emphasis on the importance of each breath, during which thoughts are personally and communally directed towards victims and the suffering. These embodied individual and collective experiences are interrelated, as one participant in a silent march explained: "from individual peace there is an irradiation towards outside and collective change becomes possible. There is the aim of covering the city with this peace and channelling this inner peace to the world." As another participant of seated meditation asserted: "by meditating we can generate a positive energy and help politicians to focus and take conscious decisions." Meditation is, then, not to be considered a 'passive' technique but rather having as an endeavour creating concrete thaumaturgical effects.

\section{Discussion}

The comparison of the two cases described in the previous sections reveals the convergence and combination of three shared aspects that enable a re-consideration of classical approaches to holistic spirituality in the vein of recent contributions (Cadge 2007; Fedele and Knibbe 2012; Hedlund-de Witt 2011; Oh and Sarkisian 2011) and-as reported in this paper-the unveiling of a more accurate picture of contemporary holistic and civic involvement. These three aspects are the forms of public expression that holistic spirituality assumes, the discursive and embodied imaginaries of change and the reinterpretation of its individualism.

\subsection{Beyond the Private: Holistic Spirituality and Its Public Resonance}

The first and clearest observation from our research is the public expression that holistic spirituality finds in these two cases. Holistic spirituality does not remain bounded to the private sphere or restricted 
to what has been termed the "spiritual milieu" (Heelas et al. 2005) but instead gains presence and visibility within the public sphere. Our interviewees do not want to remain confined within their spiritual centres and communities but rather wish to create a 'public' impact-either within a public institution or in public space. This eruption into the public sphere is not accidental but emanates from an explicit wish to be present and to be seen. This 'move' from the private to the public that has taken place during the last two decades-in the context of the growing normalization of religious diversity in Catalonia (Griera 2016) - is not arbitrary but in fact is discursively presented as the result of a reflexive and conscious decision with the aim of producing a tangible effect in the world and contributing to social transformation.

There are two elements that are interesting to underline. On the one hand, this growing public presence has not generated alarm or suspicion but has instead been greeted by widespread public acceptance. As Fedele and Knibbe (forthcoming) show, holistic spirituality is increasingly becoming a lingua franca between the religious and the secular world. Holistic spirituality derives its popularity and mainstream consent from its chameleon-like nature, which allows its members to navigate-and interrelate amidst-different social and cultural domains. This is also possible due to the readiness of holistic members to innovatively develop spiritual forms of expression and engage with different repertoires. In this regard, for instance, public meditators are blending together repertoires originating from holistic spirituality and from various social movements, while yoga teaching volunteers are able to introduce yoga to prisons by representing it as a technique conducive to physical fitness and thus a suitable leisure activity for inmates.

On the other hand, these holistic followers do not only want to be seen; they seek also to transform the public sphere. Their social engagement is closely linked to an imaginary of change. They direct their agency into the production of a specific future of harmony, peace and environmental consciousness (Cantó-Milà and Seebach 2015). The act of choosing holistic practices-either yoga or meditation-as a means of intervention in the world is not fortuitous but rather discursively elaborated by stating that transformation of one's body and self is crucial to fostering social change. Therefore, while some holistic practitioners also participate in other social movements, they nevertheless maintain that they consider these actions—-teaching yoga in prisons and doing public meditations-as forms of social engagement and activism per se.

This is interesting since it contradicts, or at least calls into question, some etic definitions and classifications of forms of social engagement used in other studies. Likewise, it fosters a more nuanced understanding of the 'efficacy' of social actions, not only in individual but also in collective terms, raising questions, including the extent to which a political demonstration is a more efficient means of challenging a political regime than a public meditation. The answers to this type of questions extend far beyond the scope of this research. It is important, nevertheless, to note that most of our interviewees were reflecting on these issues and drawing on social and holistic imaginary that justified the relevance of practicing meditation or yoga to effect world change.

\subsection{Beyond Commodification: Discursive and Embodied Imaginaries of Social Change}

In the narratives of our interviewees, there is an acknowledgment of the social perception of holistic spirituality as a 'selfish' and 'individualistic' form of religion and-in some cases-there is even an agreement of this interpretation. However, holistic practitioners commonly observe that this emphasis on 'private' practice has weakened and nowadays many holistic followers also display a greater degree of social and political engagement. There are two elements that need to be underlined in this regard. First is the question of temporality. According to our interviewees, the holistic milieu initially attracted many 'immature' people, or people in strong need of self-healing that were not capable of thinking beyond themselves. Nonetheless, they aver that the holistic movement has changed in the last decade(s) and many new social transformation projects have been initiated within holistic spiritual circles. This element of temporality—illustrating the evolution of the holistic movement—is largely absent from most of the studies on the topic yet has emerged as an important factor in our fieldwork. 
Regarding the second aspect relating to the aforementioned public articulations of holistic spirituality, it is important to acknowledge that the two studied practices-the teaching of yoga and the organization of public meditations in the streets-are not conducted in isolation but are promoted, articulated and justified in relation to a imaginary of social change. It is not easy to picture the concrete shape of this imaginary of change because is extremely diverse and a little fuzzy, but we can at least trace its contours. In general terms, we might say that is based on two related ideas: 'the personal is political' and 'social change stems from personal change.' These two maxims are discursively articulated through two dimensions: an ethics of responsibility and an ethics of reciprocity. The idea of personal responsibility is mainly elaborated through the notion of karma and the need to produce a better future for subsequent generations. Reciprocity is mainly justified through the biographical trajectories of participants which emphasize the need to return to society that which holistic spirituality has bestowed upon them. Their imaginary of a better future-and the type of values associated with a 'good life' - are closely linked to what has been termed postmaterialist values.

However, this imaginary of social change is not only articulated discursively in these general ideas and particular narratives but also in an embodied way. All these changes are, therefore, linked to a specific ethical or value change and simultaneously with the transformation of the body. In this regard, it is the body which first needs to be trained and disciplined in prison before a deeper transformation can occur and it is the body—and a specific disposition of the body—which stands in (dis)conformity in the middle of the street.

\subsection{Beyond Individualism: The Individual Who Is Not Individualistic}

A third aspect, illustrated by both cases, is the centrality of the individual and their self-expression. The organizations facilitating these holistic spiritual expressions are built on individualized engagement. With regard to the delivery of yoga courses in prisons, the involvement of the teachers begins with their own individual interest and motivation. Likewise, the public meditations, either in static or dynamic form, organized by Wake Up and Conscious Country assume the form of flash mobs, gatherings, arranged through social media networks, in which individuals freely participate. These two cases demonstrate that social engagement emerges from individual experiences of transformation. Self-realization is what motivates the sharing of holistic practices as an outpouring of gratitude, in the case of prison yoga teaching, or as the conferral of a gift in the case of public meditations. Similarly, as we already mentioned, the personal experience of self-transformation is what frames the conviction, shared by yoga teachers and mindfulness practitioners, that holistic practices are effective political tools for generating social transformation.

The empirical findings, therefore, reveal how the individual is central to these public holistic expressions, but a type of individual who is not self-centred. Contradicting some traditional interpretations, this individualized expression and commitment, rather than being either instrumental, narcissistic or apolitical, is in fact vital to holistic actors' political and social engagement. Our findings concur with the work of Lichterman (1996) on social movements, which demonstrates that the culture of self-fulfilment—of which holistic spiritualities are framed as par-excellence expressions-is not incompatible with public, political and social commitments. The holistic initiatives examined underline how this late-modern culture of self-realization has not abolished active citizenship or in any respect sabotaged political and social commitment but rather has made possible new forms of political expression based on personalized self-articulation.

Our research points to the need to acknowledge multiple forms of individualism-reaching beyond traditional instrumentalized, egotistic and egocentric expressions-in order to better comprehend the manifestation of-and rationale underpinning - the public, collective and altruistic dimensions of holistic spiritualities examined in this article. Finally, it is also important to note that these articulations of the individual, present in the social engagements of holistic actors, can also be explained by way of reference to a 'habitus affinity' —using Bourdieu (1979) concept and perspective-between social and holistic spiritual actors. As Berghuijs et al. (2013, p. 789) have shown in their research in the 
Netherlands, "demographic factors-especially education, age and gender-are stronger predictors of social engagement than religious and spiritual beliefs, experiences or practices".

\section{Conclusions}

Classical approaches to holistic spirituality have generally characterized these expressions as the epitome of late-modern trends of subjectivization, privatization and commodification. Although some initial debates emphasized the seminal counter-cultural dimensions of holistic expressions and thus underlined their subversive potential (Heelas 1996, 2008), many socio-anthropological contributions have represented these expressions as holding an elective affinity with neoliberal logic, as either a marketized product ripe for consumption or as reinforcing of an apolitical ideology. In the vein of new approaches to holistic spiritualities, which offer a more nuanced understanding of these debates, we have explored the ways in which individualized, instrumentalized, privatized and commodified holistic expressions can also be conceptualized as emerging altruistic, transformative and collective forms of spirituality. We have shown that holistic actors are not only actively involved in different social transformation projects, as underlined by a growing set of literature (Berghuijs et al. 2013; Chandler 2008; Farias and Lalljee 2008; Höllinger 2004; Oh and Sarkisian 2011) but also that holistic actors are active promoters of social initiatives aimed at nurturing social change (Hedlund-de Witt 2011).

The two cases analysed are not exceptions. In the last years, we have witnessed a growth of social and political transformation initiatives in which holistic spiritual actors and groups have either been publicly involved or have become the main promoters. Worthy of mention are the Spanish 15-M Movement and Occupy Wall Street-in which political assemblies were accompanied by regular public meditations - as well as the various ecological political movements inspired by holistic worldviews (Becci et al. forthcoming). However, in this fruitful encounter between social transformative projects and holistic spiritualities, it is necessary to distinguish between two different trends: firstly, the social and political initiatives in which holistic spiritual people are involved-and which make occasional use of holistic techniques or concepts-for instance the 15-M in Spain; secondly, those projects that aim to transform the world through the spread and utilization of holistic techniques. The latter are the kind of projects that we have analysed in this article, in both the non-profit sector and the context of social movements.

More specifically, we have analysed the public articulations of holistic spiritualities and how these are related to the discursive and embodied elaboration of an imaginary of social change. The examination of this imaginary has enabled us to reassess claims that holistic spiritualities are necessarily commodified and marketized and also to identify the rationales behind holistic forms of social involvement. Holistic volunteers anchor their actions through both an ethics of responsibility and an ethics of reciprocity and blend together the different repertoires emerging from social movements, health, leisure or religion. Their engagement has a clear collective dimension but is nevertheless articulated through individualized forms of commitment and expression. In this regard, our research has revealed the need to reconsider acceptations of individualism within current debates on various forms of political commitment (Lichterman 1996). Our fieldwork, therefore, underlines how the almost unnoticed-but increasingly public - presence of holistic spiritualities in public context adds complexity to existing conceptualizations of contemporary holistic spiritualities and encourages further examination. Two topics especially deserve future attention: firstly, future research should focus on the hidden social consequences of the spread of public holistic practices in contemporary societies and assess the impact of these emerging spiritual imaginaries for social change. Secondly, it would be especially interesting to comparatively explore this phenomenon in order to unravel how local context impacts global configurations and vice versa.

Author Contributions: Both authors have equally contributed to the recollection of data and the writing of the article. 
Funding: This paper is part of a project "EREU-MyB. Religious Expressions in the Urban Space of Madrid and Barcelona" directed by Mar Griera, and funded by the Spanish Ministry of Economy and Competitiveness (project reference: CSO2015-66198-P).

Conflicts of Interest: The authors declare no conflicts of interest.

\section{References}

Ammerman, Nancy Tatom. 2010. The Challenges of Pluralism: Locating Religion in a World of Diversity. Social Compass 57: 154-67. [CrossRef]

Arat, Alp. 2017. 'What it means to be truly human': The postsecular hack of mindfulness. Social Compass 64: 167-79. [CrossRef]

Aupers, Stef, and Dick Houtman. 2006. Beyond the spiritual supermarket: The social and public significance of new age spirituality. Journal of Contemporary Religion 21: 201-22. [CrossRef]

Becci, Irene. 2018. Zones grises. Diversité religieuse et pouvoir en institution. Social Compass 65: 199-214. [CrossRef]

Becci, Irene, Marian Burchardt, and José Casanova, eds. 2013. Topographies of Faith: Religion in Urban Spaces. Leiden: Brill.

Becci, Irene, Marian Burchardt, and Mariachiara Giorda. 2017. Religious super-diversity and spatial strategies in two European cities. Current Sociology 65: 73-91. [CrossRef]

Becci, Irene, and Alexandre Grandjean. 2018. Tracing the absence of a feminist agenda in gendered spiritual ecology: ethnographies in French-speaking Switzerland. Antropologia 5: 23-38.

Becci, Irene, Manéli Farahmand, and Alexandre Grandjean. Forthcoming. The (b)earth of a gendered eco-spirituality: Globally connected ethnographies between Mexico and the European Alps. In Secular Society, Spiritual Selves? Gendering the Overlaps and Boundaries between Religion, Spirituality and Secularity. Edited by Anna Fedele and Kim Knibbe. London: Routledge.

Beck, Ulrich. 2010. A God of One's Own: Religion's Capacity for Peace and Potential for Violence. London: Polity.

Bellah, Robert, Richard Madsen, William M. Sullivan, Ann Swidler, and Steven Tipton. 1985. Habits of the Heart: Implications for Religion. Berkeley: University of California Press.

Bender, Courtney, Wendy Cadge, Peggy Levitt, and David Smilde, eds. 2013. Religion on the Edge: De-Centering and Re-Centering the Sociology of Religion. Oxford: Oxford University Press.

Berger, Peter L. 1963. Invitació a la Sociologia: Una Perspectiva Humanística. Barcelona: Herder.

Berghuijs, Joantine, Cok Bakker, and Jos Pieper. 2013. New spirituality and social engagement. Journal for the Scientific Study of Religion 52: 775-92. [CrossRef]

Bilderbeck, Amy C., Miguel Farias, Inti A. Brazil, Sharon Jakobowitz, and Catherine Wikholm. 2013. Participation in a 10-week Course of Yoga Improves Behavioural Control and Decreases Psychological Distress in a Prison Population. Journal of Psychiatric Research 47: 1438-45. [CrossRef]

Bourdieu, Pierre. 1979. Distinction: A Social Critique of the Judgement of Taste. London: Routledge.

Bryman, Alan. 2008. Social Research Methods. New York: Oxford University Press.

Burchardt, Marian, and Mar Griera. 2019. To see or not to see: Explaining intolerance against the "Burqa" in European public space. Ethnic and Racial Studies 42: 726-44. [CrossRef]

Cadge, Wendy. 2007. Reflections on "Habits," Buddhism in America, and Religious Individualism. Sociology of Religion 68: 201-5. [CrossRef]

Cantó-Milà, Natàlia, and Swen Seebach. 2015. Desired images, regulating figures, constructed imaginaries: The future as an apriority for society to be possible. Current Sociology 63: 198-215. [CrossRef]

Carrette, Jeremy, and Richard King. 2004. Selling Spirituality: The Silent Takeover of Religion. London: Routledge.

Chandler, Siobhan. 2008. The social ethic of religiously unaffiliated spirituality. Religion Compass 2: 240-56. [CrossRef]

Dawson, Andrew. 2007. New Era-New Religions. Religious Transformation in Contemporary Brazil. Aldershot: Ashgate.

Engelke, Matthew. 2012. Angels in Swindon: Public religion and ambient faith in England. American Ethnologist 39: 155-70. [CrossRef] 
Farias, Miguel, and Mansur Lalljee. 2008. Holistic individualism in the Age of Aquarius: Measuring individualism/collectivism in new age, Catholic, and atheist/agnostic groups. Journal for the Scientific Study of Religion 47: 277-89. [CrossRef]

Fedele, Anna, and Kim Knibbe, eds. 2012. Gender and Power in Contemporary Spirituality: Ethnographic Approaches. London: Routledge.

Fedele, Anna, and Kim Knibbe, eds. Forthcoming. Secular Society, Spiritual Selves? Gendering the Overlaps and Boundaries between Religion, Spirituality and Secularity. London: Routledge.

Gauthier, François. 2013. The enchantments of consumer capitalism: Beyond belief at the Burning Man Festival. In Religion in Consumer Society: Brands, Consumers and Markets. Edited by François Gauthier and Tuomas Martikainen. London: Routledge, pp. 143-58.

Goffman, Erving. 1961. Asylums: Essays on the Social Situation of Mental Patients and Other Inmates. Brunswick: Aldine Transaction.

Griera, Mar. 2002. Consumiendo religión un análisis del consumo de productos con connotaciones espirituales entre la población juvenil. Barcelona: Fundació La Caixa.

Griera, Mar. 2014. Més enllà del "mite de la secularització": efervescència espiritual, identitats religioses i experiències transcendents. Enrahonar: An International Journal of Theoretical and Practical Reason 52: 43-65. [CrossRef]

Griera, Mar. 2016. The governance of religious diversity in stateless nations: The case of Catalonia. Religion, State E Society 44: 13-31.

Griera, Mar. 2017. Yoga in penitentiary settings: Transcendence, spirituality, and self-improvement. Human Studies 40: 77-100. [CrossRef]

Griera, Mar. Forthcoming. Is yoga a girl's thing? A case study on working class man doing yoga in jail. In Secular Society, Spiritual Selves? Gendering the Overlaps and Boundaries between Religion, Spirituality and Secularity. Edited by Anna Fedele and Kim Knibbe. London: Routledge.

Griera, Mar, and Anna Clot-Garrell. 2015a. Banal is not trivial: Visibility, recognition, and inequalities between religious groups in prison. Journal of Contemporary Religion 30: 23-37. [CrossRef]

Griera, Mar, and Anna Clot-Garrell. 2015b. Doing yoga behind bars: A sociological study of the growth of holistic spirituality in penitentiary institutions. In Religious Diversity in European Prisons. Edited by Irene Becci and Olivier Roy. London: Springer, pp. 141-57.

Hedlund-de Witt, Annick. 2011. The rising culture and worldview of contemporary spirituality: A sociological study of potentials and pitfalls for sustainable development. Ecological Economics 70: 1057-65. [CrossRef]

Griera, Mar, Anna Clot-Garrell, and Antonio Montañés. Forthcoming. De la sacralización del espacio a la secularización de la religiosidad: Expresiones religiosas en el espacio público en Barcelona. In Formas de Creer en al Ciudad. Edited by Hugo Suarez, Karina Barcenas and Cecília Delgado-Molina. Mexico: IIS-UNAM.

Heelas, Paul. 1996. The New Age Movement: The Celebration of the Self and the Sacralization of Modernity. Oxford: Blackwell.

Heelas, Paul. 2008. Spiritualities of Life: New Age Romanticism and Consumptive Capitalism. London: Wiley.

Heelas, Paul, Linda Woodhead, Benjamin Seel, Karin Tusting, and Bronislaw Szerszynski. 2005. The Spiritual Revolution: Why Religion Is Giving Way to Spirituality. Oxford: Blackwell.

Hegner, Victoria, and Peter Jan Margry, eds. 2016. Spiritualizing the City: Agency and Resilience of the Urban and Urbanesque Habitat. London: Routledge.

Hjelm, Titus, ed. 2015. Is God Back?: Reconsidering the New Visibility of Religion. London: Bloomsbury.

Höllinger, Franz. 2004. Does the counter-cultural character of New Age persist? Investigating social and political attitudes of New Age followers. Journal of Contemporary Religion 19: 289-309. [CrossRef]

Houtman, Dick, and Stef Aupers. 2007. The spiritual turn and the decline of tradition: The spread of post-Christian spirituality in 14 Western countries, 1981-2000. Journal for the Scientific Study of Religion 46: 305-20. [CrossRef]

Illouz, Eva. 2008. Saving the Modern Soul: Therapy, Emotions, and the Culture of Self-Help. Berkeley: University of California Press.

Khalsa, Kirpal Singh. 1986. New Religious Movements. Turn to Worldly Success. Journal for the Scientific Study of Religion 25: 233-47. [CrossRef]

Knoblauch, Hubert. 2008. Spirituality and Popular Religion in Europe. Social Compass 55: 140-53. [CrossRef]

Lasch, Christopher. 1979. The Culture of Narcissism: American Life in An Age of Diminishing Expectations. New York: WW Norton \& Company. 
Lichterman, Paul. 1996. The Search for Political Community: American Activists Reinventing Commitment. Cambridge: Cambridge University Press.

Liptoviesky, Gilles. 1983. La era del vacío. Barcelona: Anagrama.

Luckmann, Thomas. 1967. The Invisible Religion: The Problem of Religion in Modern Society. New York: Macmillan. Luckmann, Thomas. 1990. Shrinking transcendence, expanding religion? Sociology of Religion 51: 127-38. [CrossRef]

Oh, Seil, and Natalia Sarkisian. 2011. Spiritual individualism or engaged spirituality? Social implications of holistic spirituality among mind-body-spirit practitioners. Sociology of Religion 73: 299-322. [CrossRef]

Prat Carós, Joan. 2012. Els nous Imaginaris Culturals: Espiritualitats Orientals, Teràpies i Sabers Esotèrics. Tarragona: Universitat Rovira i Virgili.

Rabi Blolndel, Violeta. 2011. Evaluación Cualitativa del Taller Extraprogramático de Kundalini Yoga en Centro Penitenciario Femenino Metropolitano. Chile: Fundación Mujer de Luz, Unpublished report.

Rabi Blondel, Violeta. 2012. La Evaluación Social En Estrategias de Invtervención No Convencionales: Planteamientos, Técnicas y Desafíos Para El Caso Del Programa Yoga Integra En La Cárcel Femenina Metroplitana. Paper presented at VII Congreso Chileno de Sociología, PreALAS, Santiago de Chile, Chile, October 24-26.

Roof, Wade Clark. 1993. A Generation of Seekers: The Spiritual Journeys of the Baby Boom Generation. San Francisco: Harper.

Rucker, Lila. 2005. Yoga and restorative justice in prison: An experience of "response-ability to harms". Contemporary Justice Review 8: 107-20. [CrossRef]

Sointu, Eeva, and Woodhead Linda. 2008. Spirituality, gender, and expressive selfhood. Journal for the Scientific study of Religion 47: 259-76. [CrossRef]

Taylor, Charles. 2007. A Secular Age. Cambridge: The Belknap Press of Harvard University Press.

Viotti, Nicolas, and María Eugenia Funes. 2015. La política de la Nueva Era: El Arte de Vivir en Argentina. Debates Do Ner 28: 17-36. [CrossRef]

Weber, Max. 1922. The Sociology of Religion. London: Methuen.

York, Michael. 2004. Historical Dictionary of New Age Movements. Oxford: Scarecrow Press.

Zwissler, Laurel. 2018. Religious, Feminist, Activist: Cosmologies of Interconnection. Nebrask: University of Nebraska Press.

(C) 2019 by the authors. Licensee MDPI, Basel, Switzerland. This article is an open access article distributed under the terms and conditions of the Creative Commons Attribution (CC BY) license (http://creativecommons.org/licenses/by/4.0/). 

Article

\title{
Dimensions of Diversity: Toward a More Complex Conceptualization
}

\author{
Peter Beyer * and Lori G. Beaman * \\ Department of Classics \& Religious Studies, University of Ottawa, Ottawa, ON K1N 6N5, Canada \\ * Correspondence: pbeyer@uottawa.ca (P.B.); lbeaman@uottawa.ca (L.G.B.)
}

Received: 31 July 2019; Accepted: 24 September 2019; Published: 27 September 2019

\begin{abstract}
The article assesses the complexity of religious diversity through a presentation of results from the Religion and Diversity Project, a seven-year project conducted between 2010 and 2017 and centred at the University of Ottawa, Canada. Analyzing five dimensions of diversity-the religions, lived, strength, institutional and forms dimensions-it demonstrates how results from the project support the thesis that religious diversity itself is changing in all these regards, becoming more complex, and relating in complex intersectionality with other categories of diversity such as sex and gender. The article concludes by pointing to the need to expand research into religious diversity to also include the growing nonreligious diversity in Canadian and other societies.
\end{abstract}

Keywords: religious diversity; religions; law; media; education; religious strength; sex; gender; Canada; religion and migration; intersectionality

\section{Introduction}

From its initial design in 2008 to its conclusion in 2018, the Religion and Diversity Project, centred at the University of Ottawa in Canada, was guided by the following task: to understand the contours of religious diversity in Canada and to find ways to best respond to the opportunities and challenges presented by religious diversity in ways that promote a just and peaceful society. ${ }^{1}$ The project had an empirical and a normative component: to find out how religious diversity is enacted and perceived in Canada, and to develop strategies to facilitate the expression of differences in ways that would lead to the enrichment of life in Canadian society, and the greater inclusion of marginalized persons in Canadian power structures. This was, of course, a tall order.

In this article we summarize the outcome of the project, both in terms of the empirical and normative dimensions of the task. ${ }^{2}$ Perhaps the most consequential general empirical finding that emerged is that, during the eight years of the project, the contours of religious diversity changed, themselves becoming more diverse: the ways of being religiously diverse are becoming more diverse, not just the possibilities within a given category of diversity. The conclusion is not entirely unexpected or even new; we found, however, verification for it along a number of dimensions.

1 The Religion and Diversity Project (RDP) was a \$2.5 million, 7 years Major Collaborative Research Initiative funded by the Social Sciences and Humanities Research Council of Canada. The international, comparative, multidisciplinary research project involved 37 team members at 24 universities in 5 countries (Canada, US, France, UK, and Australia). The project's website is: www.religionanddiversity.ca.

2 This article reports on the activities of co-investigators and collaborators of the Religion and Diversity Project. We have also included results from associated projects. For example, Solange Lefebvre led "Diversité culturelle et religieuse dans quatre contextes nationaux: étude comparée de la dynamique identitaire et de la régulation de la religion." Sheryl Reimer-Kirkham was the Principal Investigator for "Prayer as Transgression: Exploring Accommodation of and Resistance to Prayer in Public Spaces." Jennifer Selby was the Principal Investigator of "Religion in the Everyday: Negotiating Islam in St. John's, Newfoundland and Labrador." RDP co-investigators and collaborators were members of those projects. 
As the project unfolded we began to think in terms of a 'new diversity', both in kind and in amplitude. In terms of the latter, this new diversity included a decreasing commitment to traditional majoritarian religion (Christianity), an increase in the number of people who self-describe as having no religion, an increased number and more visible presence of religions other than the majoritarian one, and a greater presence and acknowledgment of Indigenous spiritualities brought about in part by the Canadian Truth and Reconciliation Commission and its resulting Calls to Action (Beaman 2017a). The shape of religious diversity has been changing over the past decade and so have the issues related to it.

As concerns the kinds of religious diversity, its shifting contours in Canada, as in other countries, express themselves along several dimensions. The most common is the division of religion into a series of institutional and usually organized religions, including the so-called world religions, and the subdivisions of these globally recognized religions. These religions-in Canada especially Christianity, Islam, Hinduism, Sikhism, Buddhism, and Judaism - are for the most part clearly delimited from one another in the minds of most people, including their adherents. They each have their characteristic and recognizable institutions. Moreover, the field of these religions as a whole is delimited against what is not religion (to be distinguished from nonreligion: see dimension below). Thus, there are the world religions, mutually identified and recognized as distinct and yet varieties of the same thing, namely religion. Within that broad category there are subdivisions of the religions, and these in turn can exhibit subcategories or subgroups, each self-identified and recognized by others as such. Throughout this dimension, these religions tend to be distinguished, if not always defined, in terms of their attributed or self-declared adherents; their characteristic cognitive (beliefs) and performative (practices) components; and their institutional or organizational manifestations like mosques, gurdwaras, temples, churches, denominations, associations, and their (professional) representatives.

Cutting through this dimension of diversity are the varied ways that persons individually appropriate and construct their personal religious identities. This variation is not simply the micro-level of the previous one, specifically in that it can vary across the religions categories or within them, in such a way that each individual is not simply a metonym of the whole. Failure to distinguish this 'lived' religious diversity (McGuire 2008), to assume that the diversity of religions and their subdivisions already covers it, or that lived diversity is the same as the diversity of religions, misses a good deal of the important ways that religion in Canada (and elsewhere) varies. It also has important consequences for how religious people and religious institutions can effectively exercise their religious differences.

A related dimension of religious diversity concerns the different ways that social institutions, such as law, education, health, penal institutions, the state, and the media construct religion. Thus, courts have their own way of understanding what will count as religion, what force, importance, and even specific form that such religion can have, and what is permitted or forbidden to be done in its name (Berger 2015; Moon 2008; Beaman 2008, 2018). Schools teach religion in varied ways, along a continuum between 'teaching religion' as informing all aspects of pedagogy and curricula, and 'teaching about religion' as a separated and often 'optional' domain about which one ought to be informed, but in which one need not be implicated (Beaman and Van Arragon 2015). Media, from print and radio to social media, enact religion in diverse ways, from online ritual and descriptive programs to a culture of hashtags (Beaman et al. 2017; Lefebvre 2015). Governments enact diverse policies toward what is understood as religion, impacting the contours of legitimacy of religion in society (Eisenberg 2015). Health institutions vary in the ways that they 'make room for' religious and spiritual 'services', including the performance of religion in the context and delivery of health care as well as the provision of medical treatment (Reimer-Kirkham and Sharma). In all these institutional settings, it is important to realize that such construction is not simply a faithful transposition of the religious institutional dimension, the religions and their subdivisions, onto and into these other institutions. Law, media, schools, and other social institutions follow their own logic for constructing religious diversity.

A further dimension of religious diversity concerns its relative strength, essentially the variation in how much religion is present in the life of a given individual, in a given place or time, in its level 
of influence in other, not religious domains of social life, and in other social institutions. This is the amplitude dimension. Thus, for instance, individuals are religious in terms of how much they believe and practice and in how important such involvement is for them. Regionally religion appears to be more present and to exert more influence in the Maritime provinces of Canada than in British Columbia (Wilkins-Laflamme 2014, p. 296; Marks 2017); or more during the 1950s than during the 1990s (Bibby 1993). Closely associated with this dimension is the degree of presence of religion in the so-called public or private spheres, where greater public sphere presence, however assessed, indicates relatively stronger religion and greater restriction to the private sphere indicates the reverse (Luckmann 1967; Casanova 1994; Berger 1967, 1999; Habermas 2010).

A perhaps less easily understood dimension of diversity concerns diversity in forms of the religious. This dimension specifically seeks religion in other, related categories, for instance in the categories of spirituality, culture, values, and, somewhat paradoxically, nonreligion. These other forms may or may not be understood by insiders or outsiders as religion; they may or may not 'count as' religion or do so to varying degrees depending on the context. Or, to use a Luckmannian formulation, they may be comparatively invisible as religion (Luckmann 1967). The diversity in this dimension therefore consists not just in the varied concepts, but more importantly in the way these concepts interrogate the boundaries of religion and allow us to sharpen our ability to detect possible transformations in religion. They occupy what one might call the discursive or functional space of religion, in a way analogous to how the political may include but also exceed the state.

Beyond these dimensions of religious diversity, it is also meaningful to speak of a further axis of diversity which concerns the intersectionality of all these forms of religious diversity with other categories of diversity. In the case of the Religion and Diversity Project, this included sexuality and gender in particular, but other categories could have been areas of focus. We think here in particular of racial, ethno-cultural, ability, age, and class intersectionalities with religion (Vertovec 2007).

The immense literature tackling the issue of religious diversity has focused primarily on the so-called world religions and their subdivisions. The increase in this religious diversity that is attendant upon post World War Two global migration to primarily western countries like Canada has raised the double question of how the 'new' religious diversity will express itself concretely, and what effect this diversity will have for the social cohesion and identity of the countries affected. A significant part of the literature makes the underlying assumption that diversity is or can be problematic, that these differences may be too different and thereby undermine societal health, prosperity, and stability. By contrast, the Religion and Diversity Project joined another part of the literature which offers a counter-narrative, admittedly and unapologetically normative, that diversity is a positive opportunity in these regards; that greater diversity can make for a healthier, more inclusive, more prosperous, and stable society.

For those who fear that diversity may be problematic, both the strength and forms of diversity have attracted concern. In terms of strength, this literature has tended to observe the new religious diversity brought by migrant populations as both too different and too strong, thus potentially challenging the dominant culture and values which are assumed to be fundamental to the host countries (Joppke 2018; Wilson 2014). Although implicitly, the literature and public discourse have deemed these dominant values to be historically rooted in the majoritarian religions—almost always forms of Christianity—of the countries. They are articulated as cultural renditions of those religions (Seljak 2012; Beaman 2008). It is perhaps ironic that many of those who defend such implicitly Christian 'culture and heritage' are at the same time abandoning their own explicitly religious identities and practices (Clarke and MacDonald 2017). In that light, this literature recognizes that concern about the new religious diversity often takes the form of a seeming opposition to strong religion overall, regardless of which (world) religion one is talking about (Almond et al. 2000).

When focus is on the supposed problematic possibilities, the prevailing focus is therefore not so much on the religious diversity itself, as on 'strong' religion, including in the form of perceived, and often violent, extremism, mostly as concerns Muslims and Islam (Bramadat and Dawson 2014). 
In other words, the supposed danger that religious diversity may pose stems not so much from the religions dimension as from the strength dimension. Irrespective of which religion is in question, problematic religion is the sort that is too determinative in the lives of its adherents, that thereby supposedly seeks to isolate them from the rest of society because it does not share and even contradicts the dominant values. Thus, the problem (as articulated by the literature and in public debate) of Muslim women's dress is that it isolates, contradicts central norms of gender equality, and symbolizes a refusal to participate in society (Winter 2008). The problem of (too) devout Muslim men is that their devotion signals rejection of and even violent opposition to the dominant Western way of life. The problem of the Sikh kirpan is that it is a symbol of violence. The problem of faith-based schools is that these indoctrinate their pupils into a sectarian way of life that rejects dominant values like inclusion of sexual diversity and gender equality (Van Arragon 2015).

That said, however, the greater part of the literature that actually examines the new religious diversity, above all in so-called Western countries, focuses rather on how the new migrant populations, and their second generation descendants, are establishing their respective religious institutions and practices as they adapt to the new societies. By and large the dominant question informing this literature is not how these establishments may be creating problems in the host society, but rather the opposite: how the religions are helping the new populations with their religious diversity to successfully integrate into those societies (Al-Azmeh and Fokas 2007; Amarasingam 2008; Bramadat and Fisher 2010; Ebaugh and Chafetz 2000; Guest 2003; Nagata 1988; Parsons 1994; Pearson 2004; Warner and Wittner 1998; Wilkinson 2006; Bakht 2008; Breton 2012; Haddad et al. 2003; Haddad and Smith 2002; Nayar 2004; Kurien 2007; Rousseau 2012). Significantly, this literature focuses on a wide variety of religions, including various forms of Christianity, Islam, Hinduism, Buddhism, Sikhism, Judaism, New World African religions like Vaudou or Rastafarianism, Japanese new religions, and so forth. The Religion and Diversity Project added relatively few studies to this literature.

\section{Examining the Contours of Religious Diversity}

The Religion and Diversity Project addressed some of these dimensions of diversity much more directly than others. In seeking a better understanding of the contours of diversity, the research concerned itself to a limited extent with the internal dimensions of diversity in religious institutions, but more with the individual 'lived' diversity dimension, and in relation to this, with the diversity of religious forms and the strength of these forms. In this section, we draw from some of the research results of the Religion and Diversity programme of research. The following section examines aspects of some projects that related to how religious diversity is inflected in various social institutions. We then discuss intersectionality and diversity.

\section{Lived Religious Diversity in Relation to Religious Institutions, Strength, and Forms}

The Religious and Cultural Identity survey project sought to discover more about the diverse ways that individuals in Canada constructed their religious identities, especially to what degree they did so within the recognized, organized, and institutionalized (usually, world) religions, to what degree across these religions, or outside of them. The primary focus was on the individual or lived dimension, but this in relation to the diversity of institutional religions, the diversity of forms of the religious, and the diverse strength of both of these (Beyer et al. 2016, 2019a, 2019b; Beyer 2019). The survey used was designed so as to favour the religions dimension as little as possible, deliberately seeking ways in which Canadians were perhaps doing their religion inside the boundaries of institutional religions, across those boundaries, and outside those boundaries, including the possibility of not having religious identities at all.

Looking primarily at younger ages groups in the Canadian population, and seeking to focus as much on majority as minority religious populations, the project confirmed much that the literature has already been showing, but added a number of important findings. First, most Canadians who consider themselves to be religious, and who consider their religiousness to be an important part of who they 
are, still appear to construct their 'lived' religions almost entirely within the bounds of the standard, institutional religions and their subdivisions. They identify with one of the religions, and only one of them at a time; they believe and practice that religion within the bounds of the institutional parameters that one would expect: for instance, Christians go to church, pray and read their bible; Muslims pray and fast during Ramadan. While many do so in a selective way-they practice their religion à la carte - the more devout aver that they believe and practice all or most of what their religion requires of them. Their lived religions coincide with how the institutional and organized religions present themselves.

Beside these standard practitioners of the religions, however, there are a range of others who can be described as eclectic, moderate, even marginal, or more spiritual than religious. Their lived religion is often far less determinative of their overall lives; they vary quite a bit on the strength dimension of diversity, tending toward the weaker end of this diversity. Moreover, they more readily cross the boundaries within and across institutional religions, combining elements from more than one of them or from outside them altogether. These engage in religious bricolage and show that high degree of individual religious diversity that the religions dimension does not cover.

Beyond both of these diverse groups, however, there is also the substantial and growing portion of the population that finds itself outside the religious category altogether. These are the nonreligious, those who on the lived religious and strength dimensions are quite clearly entirely outside. They embody the far end of the religious forms dimension of diversity, that portion where it is questionable whether any form of religion exists at all. As the literature shows (Statistics Canada 2011; Pew-Templeton 2015; Voas and Crockett 2005; Voas and Chaves 2016; Woodhead 2016), they are a growing portion of various populations, including that of Canada. While our research raised the question of how the nonreligious positively construct their identities beyond what they are not, it did not address that aspect. Like several of the other projects conducted in the context of the Religion and Diversity Project, this research pointed to the importance of nonreligion, but could not and did not meaningfully address the actual content of this form of diversity. That would have to be the subject of future research.

With regard to specific subpopulations, previous research on religious diversity among the younger generation of more recent immigration to Canada was carried forward in a longitudinal examination of religious expression over time. Beyer, Lefebvre, Beaman, Wilkinson, and Ramji, among other Religion and Diversity Project team members, had earlier examined the range of religious identity constructions among young people with diverse backgrounds, including Muslim, Buddhist, Hindu, Christian, and Sikh (Beyer and Ramji 2013; Lefebvre and Triki-Yamani 2011). They found a great diversity in how the younger generations were relating to, carrying forward, and transforming the religions of their heritages. The range of responses included the varieties of religious identity construction outlined above, including in strength—ranging from the highly religious to those who were completely nonreligious - and form, as many expressed their religiosity not as religion, but under cognate categories, especially culture, spirituality, ethical orientation, and values. The longitudinal project carried out under the auspices of the Religion and Diversity Project found that, a decade or more later, the highly religious had stayed highly religious, almost always in the religion of their heritage. Among the others, there was also a high degree of stability over time, but where we found transformation in identities it was among these groups. The moderately or eclectically religious, as well as those who considered themselves more spiritual than religious, were much more likely to identify with more than one religion. They were more likely to engage in religious bricolage and to change the composition of that bricolage over time. The major likelihood of change, however, where it occurred, was toward a weakening of religious identity over time, moving from moderately to marginally practicing to a drop in religious identity altogether. Diversity of forms of the religious appears to be much more common in the lived religions of the less standard, the less practising, the less religious than it is among those who are highly religious (Beyer 2019). 


\section{Institutional Religions in the Context of Religious Diversity}

As we demonstrate above, individuals relate to religious diversity in their environments in different ways, reinforcing some boundaries while questioning others. Religious institutions to which these constructions relate are faced with similar questions: how do religious institutions that represent the diversity of religions negotiate their identities in a multi-religious environment, one that is moreover highly legitimated in Canada and other countries as a positive characteristic of society? Wilkinson and Reimer conducted a study on one set of such institutions, conservative Christian churches in Canada whose identity tends to include a negative view of such diversity (Wilkinson and Ambrose). These churches put emphasis on the need to spread their religion to everyone. In other words, they work towards universalization of one religion to the detriment of all others, thus contradicting, if not diversity as fact, then certainly pluralism as a normative value. In this case, their study found that these Christian churches tended to hold the two in tension, accepting the need to tolerate other religions while simultaneously claiming the need to 'evangelize' their adherents. This orientation included a sense that (secular) Canadian society did not accept them, that it sought to deny and even suppress Christianity, while admitting that the adherents of other religions also experienced prejudice and marginalization. The finding is reminiscent of an earlier study conducted by several RDP team members (Beyer, Lefebvre, Beaman, MacDonald) in which a similar sense of 'persecution' was detected among conservative Christian individuals, the sense that conservative Christian missionizing was not tolerated and that religion was under threat. (Beyer 2014; MacDonald 2018).

\section{Institutional Responses to Diversity}

Religious institutions and religious individuals determine religious diversity in various ways, but other social institutions play a large, and relatively independent, role in shaping what counts as religion. They do not simply determine what religious institutions and individuals will do, but they do help shape the context for what is easier and harder to enact in that regard. In particular, social institutions provide important contours for which sorts of religious diversity are more easily enabled, in what form, and which sorts receive meaningful recognition. The Religion and Diversity Project pursued this dimension of religious diversity in several projects, ones focusing on prisons, schools, mass media, and law in particular.

Perhaps the most telling litmus test of diversity is the extent to which prisons provide for the religious (and nonreligious) needs of prisoners (Beckford 2013, 2005). This is, argue Beckford and Cairns (2015) in their study of prisons in England and Wales and Canada, shaped by the different 'establishments' of religion. Their study addresses a number of the elements of diversity we discussed in the introduction above: the conceptualization of diversity in the world religions sense by prison administration impacts the chaplaincy services provided; the range of views about what constitutes legitimate practice within religions and the degree to which prison officials will 'accommodate' those practices; and diversity in that in-between space of religion and nonreligion that pushes at the boundaries of both. During the course of our program of research the Canadian federal government cancelled contracts of non-Christian chaplains at federal prisons. Christian chaplains were seen as being competent to offer services to everyone (CBC News 2012). ${ }^{3}$ Nonetheless, Beckford and Cairns found that overall Canadian law "governing religion and chaplaincy in the prison context reflects-and indeed legally promotes—-this sensitivity to religious diversity." (Beckford and Cairns 2015, p. 45). While they found that there is a commitment to freedom of religion and equality of opportunity to practice religions in prison within both the Correctional Service of Canada and the Prison Service of

3 "The federal government is cancelling the contracts of non-Christian chaplains at federal prisons, CBC News has learned. Inmates of other faiths, such as Muslims, Sikhs, Buddhists and Jews, will be expected to turn to Christian prison chaplains for religious counsel and guidance, according to the office of Public Safety Minister Vic Toews, who is also responsible for Canada's penitentiaries" (CBC News 2012). 
England and Wales, "the implementation of these ideals of freedom and equality takes different forms in each jurisdiction" (Beckford and Cairns 2015, p. 52). ${ }^{4}$

The provision of chaplaincy services is only one site of investigation of diversity in prison. In her research on women prisoners, Thériault (2014) examined the meaning of the plastic rosary that seemed to be ubiquitously present. The ready availability of such Catholic artifacts produced a greater profile for religion than might have been seen in life outside of prison. The rosary and crucifix import a comfort and magic to the lives of female prisoners. Thériault articulates the complex use and attitude toward the 'glow in the dark rosary', locating it as 'fascination and ridicule'. This was diversity within a particular framework which was decidedly Catholic—even a prisoner of Muslim background possessed the standard issue rosary. Thus, Thériault's work demonstrated the relationship between lived religion and institutional frames that support certain kinds of diversity and religious expression.

Another facet of institutional diversity manifested in hospitals. Reimer-Kirkham et al. (2012) found that hospitals are attempting to respond to the new diversity by creating spaces that move beyond the traditional prayer room. Some achieve this by attempting to create a space that can function for religious needs beyond Christianity, and others have created separate spaces. For example, one Vancouver hospital had a traditional and very Catholic chapel, a meditation room with an arrow pointing to the direction of Mecca, an Indigenous meeting space, and a garden space. While the first two of these addressed the diversity in institutional religion, the latter indicated a recognition of a diversity of forms in the provision of spiritual care and services. Responses to diversity were also evident at the micro level of caregivers, who for the most part genuinely attempted to be highly sensitive to the diversity of the patient populations they served. Nonetheless there were those who felt that a Christian perspective enabled them to address the needs of anyone, reflecting a universalist approach within Christianity more broadly. Another dimension of diversity within the healthcare system was community initiated response: a Sikh community that lived nearby a hospital engaged in fundraising to expand the visitor's room because the visiting hours and space were not amenable to the food and larger groups of family members (Sharma and Reimer-Kirkham 2015, p. 40). Similarly, Sikhs in the city of Brampton (Ontario), not only raised funds to build a new hospital in their city, they brought about a greater incorporation of religious and spiritual services for a diversity of institutional religions, and raised the prominence of these services as well as the visible presence of diverse religions to a level seen in few other hospitals in the country. To an extent, and as part of incorporating religious diversity into the hospital, they also transferred the kind of social and community services that religious institutions like churches are known for providing for immigrant and minority populations beyond the Sikh gurdwaras and into the health care institution itself (MacDonald 2014).

In their research on diversity in the media, Knott et al. (2016) found that Christianity still dominated the media coverage of religion in the UK, with Islam being over-represented in terms of negative coverage. Coverage of traditions other than Christianity was reductive and stereotypical (Knott et al. 2016, p. 90). Media shaped the coverage of religion by focusing on stories with political impact rather than on those things that were important to groups themselves (Knott et al. 2016, p. 174). Our Ordinary Day project built on Knott et al.'s research, gathering newspapers on September 17 in three consecutive years (2013-2015) in the UK, Canada, Australia and Finland. We reviewed the newspapers for any religion-related entries, including news stories, editorials and comments, reader responses, reviews, obituaries, advertisements, images, classified ads and public notices. We considered conventional religion, common religion and the secular sacred. ${ }^{5}$ Christianity dominates in these data,

4 "Muslim prisoners and chaplains alike hold widely differing views about what it means to practice Islam faithfully. In this way, agencies of the state in England \& Wales attempt to manage religious diversity in prisons by imposing definitions of permissible religious practices and entitlements, not all of which are legitimate in the eyes of religious authorities and practitioners" (Beckford and Cairns 2015, p. 44).

5 Conventional religion refers to: Roman Catholicism, Protestantism, Councils of Churches, Religion General, Other Christian Churches and Groups, Church History, New Religious, Movements, Islam, Hinduism, Buddhism, Sikhism, Judaism, Other World Religions, Mixed, and Other. Common religion refers to: Magic, Witchcraft, Chance, Signs, Ghosts, Spiritualism 
though often in passing. Islam was often the focus of news stories. Data analysis in this study is still underway, but we have this insight on Australia from Halafoff and Weng: "Christianity, in particular permeates all aspects from news, to entertainment, to business, and to sport. Islam received the most main story news coverage and most of this was negative and associated with Islamic State and protests against mosque building" (Halafoff and Went).

In relation to education, we found that in Canada there was little systematic information given to students on religion or religious diversity. This enters the controversial territory of education about religion and religious literacy. The major challenge here is that materials and approaches tend to essentialize religious groups, flattening the texture of lived religion and erasing elements of strength that make up diversity within religion (i.e., how much people actually participate in the standard elements of a given religion). Quebec is the exception to the general tendency toward no education about religion. In that province the Ethics and Religious Culture course is mandatory. Outside of Quebec religion is subsumed under the larger state project of multiculturalism, and most young people "appear to end up understanding religious diversity as the diversity of religions, as the diversity of adherents to these religions and mostly in terms of the so-called world religions" (Beaman et al. 2017, p. 254).

Under the direction of Solange Lefebvre, a Religion and Diversity co-investigator, a related project on how states use public commissions to manage their response to religious diversity through public policy focused on Quebec, France, Belgium, and the United Kingdom. What the respective commission reports showed was a common suspicion of strong religion, especially Islam, with the fear that this threatened to undermine social cohesion by encouraging new populations not to integrate, to lead separate, "communal" lives which could act as the seedbeds for extremism, violence, and the negation of core societal values. In each state, policies were recommended by the commissions that would lead to the opposite: integration, adoption of common values, participation by everyone in society, and, notably, the general restriction of Islam to the so-called private sphere and even its exclusion from the public sphere, for instance, in banning religious symbols/clothing from public institutions like health, education, and public administration (Lefebvre and Beaman 2014; Lefebvre and Brodeur 2017).

Legal analyses show that law also shapes religion (Berger 2015), although religion cannot be seen as passive in this process, as was demonstrated by Sullivan (2017) in her presentation at the final team meeting in 2017. As Berger notes "Law tolerates that which is different only so long as it is not so different that it challenges the organizing norms, commitments, practices, and symbols of the Canadian constitutional rule of law" (Berger 2015, p. 119). In keeping with our observations about other social institutions, religious diversity is supported as long as the religion under scrutiny or consideration is not too strong. This perhaps explains why religious freedom under section 2(a) of the Canadian Charter of Rights and Freedoms has been the primary locus of legal discussions of religion. As Bruce Ryder observes, there has never been a finding by the Supreme Court of Canada based on the s. 15 equality provisions of the Charter. An equality rights approach might expose the hard line between acceptable religion and 'other' religion (Ryder 2017).

Within social institutions Christianity still dominates, even in so-called 'secular' social institutions. What is, however, changing is that there is an acknowledgment that for the most part this is no longer acceptable, in part because there is an increasing number of people for whom religion is not relevant, but also because of the increased presence of non-Christian religion through migration as well as heightened awareness of Indigenous spiritual practices. Social institutions are in many cases shifting their practices to reflect this new diversity and to exhibit a more inclusive approach. To be sure, this

and Spirit Possession, Psychic Powers, Luck, Superstitions, Gambling, Fortune Telling Techniques, Fate and Destiny, Other Supernatural Beings, The Unexplained, Folk Religion, Folk Practices, Mythology, Gypsies, New Age, Mixed, and Other. Secular/sacred refers to: Secularism, religion and secular, Atheism, Humanism, Religion and Science, Liberalism, Spirituality, Religion-like, Mixed, and Other. 
varies from context to context and it is also contested by social actors with a range of interests (Beckford and Cairns 2015; Sharma and Reimer-Kirkham 2015; Lefebvre 2015; Beaman et al. 2017, 2015).

\section{Intersectionality}

Religious diversity, in whatever dimension one examines it, expresses a major way in which people in society are different and above all a way in which Canadian society, through its institutional and power structures, enables (or constrains) them to be different. Religious diversity helps structure the stratification system of Canadian and indeed global society. It is not alone in this regard, however. Religious differences stand in relation to and intersect with other social characteristics in determining power distribution, exclusion and inclusion, recognition and invisibility in that society. Such intersecting criteria include gender, sex and sexual orientation, race, ethnicity, class, and what one can broadly class as culture (e.g., in the Canadian context, indigeneity and nationality). The Religion and Diversity Project focused its attention primarily on gender and sexuality.

\section{The Gender, Sexuality, Youth and Religion Project}

The Gender, Sexuality, Youth and Religion Project led by Pamela Dickey Young and Heather Shipley used a multi-method approach (interviews, survey, video diaries) and was inspired by a study conducted by Andrew Yip et al. in the UK (Yip et al. 2011). Dickey Young and Shipley examined the lived religion, lived sexuality and lived gender of nearly 500 youth. The majority, $61 \%$, were Christian, but their participants included Muslims, Sikhs, Buddhists, Jews, Hindus and a large group of nonreligious (about 34\%), as well as people who combine religious traditions. Their study began with the first dimension of diversity-a sample of young people who were imagined at the outset to belong to diverse religious traditions in the 'world religions' paradigm. But, things rapidly grew more complicated as Young and Shipley discovered that many of the youth were unwilling to adopt singular identity categories. The boundary between the religious and the not religious was often fuzzy, with multiple identities co-existing within the same person, frequently layered and intersecting with gender and sexuality. Flexibility characterized many of their participants. However, equally as present was a clear indication that for those who did have a strong religious identity, religion informs their approach to matters of sexuality, including pre-marital sex. But, a 'whatever' attitude toward the actions of others characterized almost all of the participants. This 'whatever' attitude is not, as Dickey Young and Shipley point out and drawing on the research findings of Anna Halafoff and Laura Gobey in Australia (Halafoff and Gobey 2019), indifference, but an active acceptance of difference characterized by respect for others who might not share one's own values. Dickey Young and Shipley's research highlights a number of dimensions of religious diversity that pressed us to refine our conceptualization of the idea of religious diversity. Most importantly, their findings suggest, as they say, that a new grammar of religion for discussing youth and identity is required. Moreover, they also suggest that older adults may express their identities more clearly not because they experience them in more rigid terms, but because they have learned to express them in the rather rigid vocabulary we currently use. For the youth they interviewed the big question is not 'who am I', but 'how will I participate in the world'. This of course goes to one of the core preoccupations of the Religion and Diversity Project, which evolved into a question of how to live well together in a complex future. The question of 'how will I participate in the world' goes to the very heart of diversity, as Dickey Young and Shipley discovered, in that a key theme from their participants was that of negotiation.

Donald Boisvert also considered the intersection of religion and sexuality, specifically in relation to the Anglican Church in Canada. Sexuality is an issue which continues to challenge the church, illustrating the extent and consequences of internal diversity, as well as the complexity of the intersections under consideration (Young 2006; Ziedler 2019). Boisvert argued, for example, that "Religion makes queer spaces, and queer people, both possible and necessary. What could be queerer-and, by extension, more saintly — than a strappingly-bachelor, man-loving, mother-obsessed, Rome-centred, liturgically-enamoured, ecclesiastically-rebellious, yet ultimately charitable and good 
man of the church, than an Anglican priest like Edmund Wood? Not many, I would think, yet perhaps not enough" (Boisvert 2013, p. 231).

Diversity is also often complicated by considerations of the intersection of gender and religion. For example, Amiraux has noted the complex negotiations around the wearing of hijab and niqab for Muslim women. The 'imperiled Muslim woman' is supported by discourse akin to gossip (Amiraux 2016) and acts as a figure, which shapes the non-Muslim public imaginary of who Muslim women are (Selby et al. 2018). The politics of gender are different for Muslim women and men-the latter being imagined in a range of ways, the Terrorist and the Enlightened Muslim Man being two of the most common (Selby et al. 2018). Again, these figures shape social interactions and frame acceptable and nonacceptable diversity both internally, in relation to amplitude and vis-à-vis institutional and state responses.

Discussions of intersectionality highlight the necessity of considering religion and religious diversity as fundamentally socially located. Religion is shaped by and intertwined with its social context, constructed by social actors through social relations in complex ways (Furseth 2018). This social location also includes spatial location, which are continuously changing geographies also linked to changing demographies and the new diversity. Church buildings are transitioning into condominiums, convents into university residences, and taking new life by expanding their repertoires, sometimes to other religious groups and sometimes to other functions, such as concerts, daycare centres, and meeting spaces unrelated to, properly speaking, church business (Dovlete and Beaman 2017). These spatial dynamics are also part of the complex picture of diversity.

\section{Conclusions: Multidimensional Religious Diversity in a Transforming Landscape}

James Beckford cautions against the conflation of religious diversity, the degree of acceptance of certain religions in the public sphere, the ideological commitment to the value of religious diversity and the increasing scope of religious acceptability (Beckford 2003, p. 100). We took his caution seriously in our project and have reflected it in our attempt to identify and disentangle various dimensions of diversity in this paper. As alluded to at the beginning, we did engage in normative assumptions about diversity. We were cautious, for example, about the language of management, which sees diversity as a problem to be regulated. Instead we took the position that diversity is an opportunity and an asset, which obviously imputes a positive connotation to it. From the outset we questioned the dominant narrative of tolerance and accommodation as the appropriate responses to the challenges of diversity. One approach to thinking about diversity was deep equality (Beaman 2014, 2017b), which focuses attention first on social actors as they engage with difference in their daily lives. Very often the 'response' to diversity is imagined in isolation from social life. This results in a top down response that engages with law, states, institutions but not by mobilizing the many ways that people already negotiate and navigate difference (Selby et al. 2018). Deep equality proposes these everyday moments as the appropriate beginning place for modeling living well together in diverse societies. This is not to say that institutional and state responses have no place, but that excluding the social everyday ignores a rich source of narratives and models that can be mobilized to respond to the challenges of diversity as an opportunity.

Rather than beginning with a goal of social cohesion, ${ }^{6}$ which too often imagines 'our values' in ways that replicate problematic power relations such as colonialism and patriarchy, the goal of living well together folds in the concept of diversity and seeks spaces of similarity rather than sameness or difference. In part, this approach has been reflected in the Canadian version of multiculturalism as a state project. This has been recently transformed into an articulation of diversity and the need for inclusion. Another refinement has been an attempt to address the legacy of colonial treatment of

6 See, for example, Jenson (2019) 
Indigenous peoples through the process of reconciliation. Conceptually and on the ground, diversity is dynamic in all of its dimensions.

The question of religious diversity, how it manifests itself, how it provides sites of political contestation and stratification or inclusion/exclusion, how it inflects with other social dimensions, and how to respond to it in the effort toward more peaceable and just societies, are clearly very complex questions. The Religion and Diversity Project, in putting all these aspects under its purview, could only hope to make modest contributions in addressing any of them. Some of those contributions have been outlined here, mostly for Canada, but also with a comparative view to other countries like Australia, the UK, and France. In spite of the modesty of the outcomes, they were nonetheless important because they brought into sharp and incontrovertible view that the questions are indeed complex, not subject, for instance, to a simple understanding in terms of juxtaposition of supposedly clear and clearly identified religions that just have to be treated equally. Religious diversity is something different depending on the dimension of diversity one is viewing; the relation of those dimensions is complex, contested, and sometimes contradictory. Moreover, each of the dimensions is exhibiting a different sort of transformation: the religions transform as those previously absent in Canada assert their presence to a greater and greater extent, conditioning and challenging thereby the hitherto dominant Christianity in its multiple variations. Religion of one sort seems to be progressively weakening, and yet there is also a concern about religion being too strong at times. Religious diversity intersects with various other important diversities in complex and changing ways; and formally secular institutions recognize and seek to control this diverse religion in different ways.

Among its many outcomes, the Religion and Diversity Project pointed to the diverse ways forward in each of the dimensions, but perhaps in particular with respect to the dimension that we have called the diversity of religious forms. Hovering at the edges of most of the projects carried out was the question of what lies beyond and outside the recognized religions and their subdivisions. The increasing presence of the spiritual but not religious, youth who construct their (religious) identities across the boundaries between religions and between religion and nonreligion, the marginally or culturally religious, and especially those outside religion altogether, these all point to the increasing influence of nonreligion in these questions. Much of the contestation surrounding religion seems to be across this boundary between religion and nonreligion, yet, in spite of increasing work in this area, we know little about this other side that is nonreligion. This then is the subject of the successor project to the Religion and Diversity Project. The Nonreligion in a Complex Future project begins.

Author Contributions: This article was co-written by the two authors in equal proportion. Neither the one nor the other made a larger or smaller contribution.

Funding: The Religion and Diversity Project was funded by the Social Sciences and Humanities Research Council of Canada, Grant number 412-2010-1000.

Conflicts of Interest: The authors declare no conflict of interest.

\section{References}

Al-Azmeh, Aziz, and Effie Fokas. 2007. Islam in Europe: Diversity, Identity and Difference. Cambridge: Cambridge University Press.

Almond, Gabriel A., R. Scott Appleby, and Emmanuel Sivan, eds. 2000. Strong Religion: The Rise of Fundamentalisms around the World. Chicago: University of Chicago Press.

Amarasingam, Amarnath. 2008. Religion and Ethnicity among Sri Lankan Tamil Youth in Ontario. Canadian Ethnic Studies/Études Ethniques au Canada 40: 149-69. [CrossRef]

Amiraux, Valérie. 2016. Visibility, transparency and gossip: How did the religionof some (Muslims) become the public concern of others? Critical Research on Religion 4: 37-56. [CrossRef]

Bakht, Natasha, ed. 2008. Belonging and Banishment: Being Muslim in Canada. Toronto: TSAR Publications.

Beaman, Lori G. 2008. Defining Harm: Religious Freedom and the Limits of the Law. Vancouver: UBC Press.

Beaman, Lori G. 2014. Deep Equality as an Alternative to Accommodation and Tolerance. Nordic Journal of Religion and Society 27: 89-111. 
Beaman, Lori G. 2017a. Recognize the New Religious Diversity. Canadian Diversity 14: 17-19.

Beaman, Lori G. 2017b. Deep Equality in an Era of Religious Diversity. Oxford: Oxford University Press.

Beaman, Lori G. 2018. Reading Religion Through the Lessons of Legal Decisions and Reactions to Them. In Re-Imagining Religion and Belief: 21st Century Policy and Practice. Edited by Christopher Baker, Beth R. Crisp and Adam Dinham. Bristol: Policy Press, pp. 95-114.

Beaman, Lori G., and Leo Van Arragon. 2015. Issues in Religion and Education: Whose Religion? Leiden: Brill.

Beaman, Lori G., Lauren L. Forbes, and Christine L. Cusack. 2015. Law's Entanglements: Resolving Questions of Religion and Education. In Issues in Religion and Education: Whose Religion? Edited by Lori G. Beaman and Leo Van Arragon. Leiden: Brill, pp. 156-82.

Beaman, Lori G, Peter Beyer, and Christine L. Cusack. 2017. Young people and religious diversity: A Canadian perspective. In Young People's Attitudes to Religious Diversity. Edited by Elisabeth Arweck. London: Routledge, pp. 245-62.

Beckford, James A. 2003. Social Theory and Religion. Cambridge: Cambridge University Press.

Beckford, James A. 2005. Muslims in the Prisons of Britain and France. Journal of Contemporary European Studies 13: 287-97. [CrossRef]

Beckford, James A. 2013. Religious Diversity in Prisons: Chaplaincy and Contention. Studies in Religion 42: 190-205. [CrossRef]

Beckford, James A., and Ilona C. M. Cairns. 2015. Muslim Prison Chaplains in Canada and Britain. The Sociological Review 63: 36-56. [CrossRef]

Berger, Peter L. 1967. The Sacred Canopy: Elements of a Sociological Theory of Religion. New York: Doubleday and Company Inc.

Berger, Peter L., ed. 1999. The Desecularization of the World: Resurgent Religion and World Politics. Grand Rapids: Eerdmans.

Berger, Benjamin L. 2015. Law's Religion: Religious Difference and the Claims of Constitutionalism. Toronto: University of Toronto Press.

Beyer, Peter. 2014. Regional Differences and Continuities at the Intersection of Culture and Religion: A Case Study of Immigrant and Second-Generation Young Adults in Canada. In Religion in the Public Sphere: Canadian Case Studies. Edited by Solange Lefebvre and Lori G. Beaman. Toronto: University of Toronto Press, pp. 66-94.

Beyer, Peter. 2019. Variable Religious Identities among Emerging and Prime Adults in Canada. Paper presented at the International Society for the Sociology of Religion, Barcelona, Spain, July 9-12.

Beyer, Peter, and Rubina Ramji. 2013. Growing Up Canadian: Muslims, Hindus, Buddhists. Montreal and Kingston: McGill Queen's University Press.

Beyer, Peter, Alyshea Cummins, and Scott Craig. 2016. Measuring Religious Identity Differently: A Canadian Survey Study. Bulletin for the Study of Religion 45: 10-15. [CrossRef]

Beyer, Peter, Alyshea Cummins, and Scott Craig. 2019a. Religious/Spiritual ldentity among Younger Adults in Canada: A Complex Portrait. In Young People and the Diversity of (Non)Religious Identities in International Perspective. Edited by Elisabeth Arweck and Heather Shipley. Berlin: Springer, pp. 15-31.

Beyer, Peter, Scott Craig, and Alyshea Cummins. 2019b. Religious Identity Construction among Young Adults in Canada: The Religious, the Spiritual, and the Non- Religious. In Youth, Religion, and Identity in a Globalizing Context International Perspectives. Edited by Paul Gareau, Spencer Bullivant and Peter Beyer. Leiden: Brill, pp. 33-52.

Bibby, Reginald W. 1993. Unknown Gods: The Ongoing Story of Religion in Canada. Toronto: Stoddart Pub.

Boisvert, Donald L. 2013. What Kind of Man Are You? Same-Sex Relations, Masculinity and Anglican Queer Malaise. Studies in Religion 42: 226-36. [CrossRef]

Bramadat, Paul, and Lorne Dawson, eds. 2014. Religious Radicalization and Securitization in Canada and Beyond. Toronto: University of Toronto Press.

Bramadat, Paul, and Susie Fisher. 2010. Religious Organizations and the Integration of Immigrants, Refugees, and Temporary Foreign Workers: An Annotated Bibliography and List of Community Organizations. Vancouver: Metropolis British Columbia.

Breton, Raymond. 2012. Different Gods: Integrating Non-Christian Minorities into a Primarily Christian Society. Montreal and Kingston: McGill-Queen's University Press.

Casanova, José. 1994. Public Religions in the Modern World. Chicago: University of Chicago Press. 
CBC News. 2012. Non-Christian Prison Chaplains Chopped by Ottawa. Available online: http://www.cbc.ca/new s/canada/british-columbia/story/2012/10/04/bc-non-christian-prison-chaplains-cancelled.html (accessed on 25 July 2019).

Clarke, Brian, and Stuart MacDonald. 2017. Leaving Christianity: Changing Allegiances in Canada since 1945. Montreal and Kingston: McGill-Queen's University Press.

Dovlete, Monica Grigore, and Lori G. Beaman. 2017. Ghostly Presence: An Abandoned Space and Three Religious Communities in Parishville, Quebec. Eurostudia 12: 82-104. [CrossRef]

Ebaugh, Helen Rose, and Janet Saltzman Chafetz, eds. 2000. Religion and the New Immigrants: Continuities and Adaptations in Immigrant Congregations. Walnut Creek: AltaMira Press.

Eisenberg, Avigail. 2015. What is wrong with a liberal assessment of religious authenticity? In Authenticity, Autonomy and Multiculturalism. Edited by Geoffrey Brahm Levey. New York: Routledge, pp. 145-62.

Furseth, Inger, ed. 2018. Religious Complexity in the Public Sphere: Comparing Nordic Countries. Cham: Palgrave Macmillan.

Guest, Kenneth J. 2003. God in Chinatown: Religion and Survival in New York's Evolving Immigrant Community. New York: New York University Press.

Habermas, Jürgen. 2010. Notes on a Post-Secular Society. New Perspectives Quarterly 25: 17-29. [CrossRef]

Haddad, Yvonne Yazbeck, and Jane I. Smith, eds. 2002. Muslim Minorities in the West: Visible and Invisible. Walnut Creek: Altamira Press.

Haddad, Yvonne Yazbeck, Jane I. Smith, and John L. Esposito, eds. 2003. Religion and Immigration: Christian, Jewwish, and Muslim Experiences in the United States. Walnut Creek: AltaMira Press.

Halafoff, Anna, and Laura Gobey. 2019. "Whatever"? Religion, Youth, and Identity in 21st Century Australia. In Youth, Religion, and Identity in a Globalizing Context. Edited by Paul L. Gareau, Spencer Culham Bullivant and Peter Beyer. Leiden: Brill, pp. 255-77.

Halafoff, Anna, and Enqi Went. Forthcoming. Religion on an Ordinary Day: Australia. In An Ordinary Day: An International Study of Religion in the Media. Edited by David Michels and Mathilde Vanasse-Pelletier.

Jenson, Jane. 2019. Intersections of Pluralism and Social Cohesion. Global Centre for Pluralism. Available online: https://www.pluralism.ca/wp-content/uploads/2019/02/Jane-Jenson-Social-Cohesion-FINAL.pdf (accessed on 25 July 2019).

Joppke, Christian. 2018. Culturalizing religion in Western Europe: Patterns and puzzles. Social Compass 65: 234-46. [CrossRef]

Knott, Kim, Elizabeth Poole, and Teemu Taira. 2016. Media Portrayals of Religion and the Secular Sacred. London: Routledge.

Kurien, Prema A. 2007. A Place at the Multicultural Table: The Development of an American Hinduism. New Brunswick: Rutgers University Press.

Lefebvre, Solange. 2015. From Religion to Spirituality in Education: Towards a Political Regulation of Spirituality? In Issues in Religion and Education: Whose Religion? Edited by Lori G. Beaman and Leo Van Arragon. Leiden: Brill, pp. 183-207.

Lefebvre, Solange, and Lori G. Beaman, eds. 2014. Religion in the Public Sphere: Canadian Case Studies. Toronto: University of Toronto Press.

Lefebvre, Solange, and Patrice Brodeur, eds. 2017. Public Commissions on Cultural and Religious Diversity: Analysis, Reception and Challenges. London: Routledge.

Lefebvre, Solange, and Amina Triki-Yamani. 2011. Jeunes adultes immigrants de deuxième génération. Dynamiques ethnoreligieuses et identitaires. Études ethniques canadiennes/Canadian Ethnic Studies 43: 183-201. (In French). [CrossRef]

Luckmann, Thomas. 1967. The Invisible Religion: The Problem of Religion in Modern Society. New York: The Macmillan Company.

MacDonald, Arlene. 2014. In the name of the Guru: The Guru Nanak Emergency Centre, Sikh Gurdwaras, and the pursuit of religious and health equality. Paper presented at the American Academy of Religion, San Diego, CA, USA, November 22-25.

MacDonald, Arlene. 2018. 'Hijab Envy': The Visible Angst among Immigrant Christians in a Pluralist Canada. Contemporary Religion 33: 53-69. [CrossRef]

Marks, Lynne. 2017. Infidels and the Damn Churches: Irreligion and Religion in Settler British Columbia. Vancouver: UBC Press. 
McGuire, Meredith. 2008. Lived Religion: Faith and Practice in Everyday Life. New York: Oxford University Press. Moon, Richard, ed. 2008. Law and Religious Pluralism in Canada. Vancouver: UBC Press.

Nagata, Judith. 1988. The Role of Christian Churches in the Integration of Southeast Asian Immigrants in Toronto. Contributions to Southeast Asian Ethnography 6: 41-60.

Nayar, Kamala Elizabeth. 2004. The Sikh Diaspora in Vancouver: Three Generations amid Tradition, Modernity, and Multiculturalism. Toronto: University of Toronto Press.

Parsons, Gerald, ed. 1994. The Growth of Religious Diversity: Britain from 1945. London: Routledge.

Pearson, Anne Mackenzie. 2004. Being Hindu in Canada: Personal Narratives from First and Second Generation Immigrant Hindu Women. Religious Studies and Theology 23: 55-88. [CrossRef]

Pew-Templeton. 2015. Canada. Pew-Templeton Global Religious Futures Project. Available online: http://www.globalreligiousfutures.org/countries/canada\#/?affiliations_religion_id=0\&affiliations_year=2 010\&region_name=All\%20Countries\&restrictions_year=2016 (accessed on 25 July 2019).

Reimer-Kirkham, Sheryl, and Sonya Sharma. Forthcoming. Prayer as Transgression? The Social Relations of Prayer. Montreal: McGill-Queen's University Press.

Reimer-Kirkham, Sheryl, Sonya Sharma, Barb Pesut, Richard Sawatzky, Heather Meyerhoff, and Marie Cochrane. 2012. Sacred spaces in public places: Religious and spiritual plurality in health care. Nursing Inquiry 19: 202-12. [CrossRef]

Rousseau, Louis, ed. 2012. Le Québec après Bouchard-Taylor: Les Identités Religieuses de l'Immigration. Québec: Les Presses de l'Université du Québec à Montréal. (In French)

Ryder, Bruce. 2017. Intervention in Panel 9: Law. Paper presented at Religion and Diversity Project Final Team Meeting, Ottawa, ON, Canada, October 26-28.

Selby, Jennifer A., Amélie Barras, and Lori G. Beaman. 2018. Beyond Accommodation: Everyday Narratives of Muslim Canadians. Vancouver: UBC Press.

Seljak, David. 2012. Protecting religious freedom in a multicultural Canada. Canadian Diversity 9: 8-11.

Sharma, Sonya, and Sheryl Reimer-Kirkham. 2015. Faith as social capital: Diasporic women negotiating religion in secularized healthcare services. Women's Studies International Forum 49: 34-42. [CrossRef]

Statistics Canada. 2011. Religion (108), Immigrant Status and Period of Immigration (11), Age Groups (10) and Sex (3) for the Population in Private Households of Canada, Provinces, Territories, Census Metropolitan Areas and Census Agglomerations, 2011 National Household Survey. Available online: http://www12.statcan.gc.ca/nhs-enm/2011/dp-pd/dt-td/Rp-eng.cfm?LANG=E\&APATH=3\&DETAIL=0\& $\mathrm{DIM}=0 \& \mathrm{FL}=\mathrm{A} \& \mathrm{FREE}=0 \& \mathrm{GC}=0 \& \mathrm{GID}=0 \& \mathrm{GK}=0 \& \mathrm{GRP}=0 \& \mathrm{PID}=105399 \& \mathrm{PRID}=0 \& \mathrm{PTYPE}=105277 \& \mathrm{~S}=0$ $\&$ SHOWALL=0\&SUB=0\&Temporal=2013\&THEME=95\&VID=0 (accessed on 25 July 2019).

Sullivan, Winnifred F. 2017. Intervention in Panel 9: Law. Paper presented at Religion and Diversity Project Final Team Meeting, Ottawa, ON, Canada, October 26-28.

Thériault, Barbara. 2014. Porter le chapelet. Formes religieuses dans une prison pour femmes. Studies in Religion/Sciences Religieuses 43: 172-80. [CrossRef]

Van Arragon, Leo. 2015. "We Educate, They Indoctrinate": Religion and the Politics of Togetherness in Ontario Public education. Ph.D. thesis, University of Ottawa, Ottawa, ON, Canada.

Vertovec, Steven. 2007. Super-diversity and its implications. Ethnic and Racial Studies 30: 1024-54. [CrossRef]

Voas, David, and Mark Chaves. 2016. Is the United States a Counterexample to the Secularization Thesis? American Journal of Sociology 121: 1517-56. [CrossRef]

Voas, David, and Alasdair Crockett. 2005. Religion in Britain: Neither Believing nor Belonging. Sociology 39: 11-28. [CrossRef]

Warner, R. Stephen, and Judith G. Wittner, eds. 1998. Gatherings in Diaspora: Religious Communities and the New Immigration. Philadelphia: Temple University Press.

Wilkins-Laflamme, Sarah. 2014. Towards Religious Polarization? Time Effects on Religious Commitment in US, UK and Canadian Regions. Sociology of Religion 75: 284-308. [CrossRef]

Wilkinson, Michael. 2006. The Spirit Said Go: Pentecostal Immigrants in Canada. New York: Peter Lang.

Wilkinson, Michael, and Linda Ambrose. Forthcoming. Immigration and Religious Diversity. In After the Revival: Pentecostalism and the Making of a Canadian Church. Montreal: McGill-Queen's University Press, chp. 7.

Wilson, Erin. 2014. 'Culture' or 'Religion'? Understanding the Popularity of the Passion. ReligionFactor, April 17. Available online: https://www.rug.nl/research/centre-for-religious-studies/religion-conflict-globalization/blo g/culture-or-religion-understanding-the-popularity-of-the-passion-17-04-2014 (accessed on 25 July 2019). 
Winter, Bronwyn. 2008. Hijab and the Republic: Uncovering the French Headscarf Debate. Syracuse: Syracuse University Press.

Woodhead, Linda. 2016. The Rise of 'No Religion' in Britain: The Emergence of a New Cultural Majority. Journal of the British Academy 4: 245-61.

Yip, Andrew Kam-Tuck, Michael Keenan, and Sarah-Jane Page. 2011. Religion, Youth and Sexuality: Selected Key Findings from a Multi-Faith Exploration. Nottingham: University of Nottingham.

Young, Pamela Dickey. 2006. Same-sex marriage and the Christian churches in Canada. Studies in Religion/Sciences Religieuses 35: 3-23. [CrossRef]

Ziedler, Maryse. 2019. Anglican Church Rejects Same-Sex Marriage Approvals in Vote. CBC News, July 13. Available online: https://www.cbc.ca/news/canada/british-columbia/anglican-church-of-canada-votes-agai nst-same-sex-marriage-1.5211051 (accessed on 25 July 2019).

(C) 2019 by the authors. Licensee MDPI, Basel, Switzerland. This article is an open access article distributed under the terms and conditions of the Creative Commons Attribution (CC BY) license (http://creativecommons.org/licenses/by/4.0/). 



\title{
Article \\ 'Non-Religion' as Part of the 'Religion' Category in International Human Rights
}

\author{
Alan G. Nixon \\ Religion and Society Research Cluster, Western Sydney University, Penrith, NSW 2751, Australia; \\ a.nixon@westernsydney.edu.au
}

Received: 7 August 2019; Accepted: 5 February 2020; Published: 10 February 2020

\begin{abstract}
Religion' still occupies and maintains a position of formal and informal privilege in many current societies. It retains these privileges despite the increasing numbers of people who label themselves 'non-religious'. There is also evidence that overtly non-religious people are being persecuted due to the continuation of these privileges. This paper will examine such treatment of the non-religious in the context of human rights instruments and laws. It lays out the international law case for the rights of the non-religious. It also discusses the extent to which state actors have or have not ignored human rights standards in their persecution or deprivileging of non-religious people. This paper will proceed through a three-step analysis. Step 1 is to examine the aspirational Universal Declaration of Human Rights (UDHR) in relation to the non-religious. The relevant sections of the UDHR and interpretations that they have received will be discussed. Step 2 is to do the same with the binding International Covenant on Civil and Political Rights (ICCPR). Finally, Step 3 is to give examples of lower-level and local laws, where I shall examine the extent to which individual countries' laws and practices toward non-religious people support or contradict the treaty commitments that those countries have made. The continuation in coercion/persecution cases suggests that something is amiss with human rights protections being provided to the non-religious. If we are to create social structures that are more inclusive of the non-religious and to advocate for non-religious rights, it is necessary to examine the societal power and privilege still held by 'religion'. It is hoped that this article can inform and encourage further similar engagements among sociologists, religious studies scholars, activists and lay-people interested in the treatment of non-religious peoples.
\end{abstract}

Keywords: non-religion; atheism; religion; persecution; law; policy

\section{Introduction}

Religion continues to occupy a position of privilege, both formally and informally, in many contemporary societies (Beaman et al. 2018). These forms of privilege are maintained through the presence of majority norms that pervade social life, such as discursive frameworks and law. For example, two of the common tropes in discursive frameworks around 'religion' are that everyone has a religion (LoRusso 2017) and that religion is good for people (Zuckerman 2013). Both of these tropes lead to 'religion' being seen as ubiquitous and necessary in many societies. They also informally paint those without religion as outside of normal society and less trustworthy. Likewise, laws have often reflected the religious views of the majority, since the majority make the laws and the connection between morality and religion has been strong in most societies. This means that even in more 'secularised' systems the influence of religion remains strong and many formal laws will reflect the will of the religious majority (see Australian examples in Maddox 2005; Kirby 2009). So, we can see that informal and formal privileging of 'religion' continues in many societies, despite the increasing number of the world's population that is non-religious.

This article aims to use international law documents/principles and legal cases as examples to discuss the ongoing human rights issues experienced by the non-religious in many parts of the world. 
Although using international laws and local interpretations of such laws, I am writing for sociologists, scholars of religious studies, activists and lay-people interested in the treatment of non-religion. As Beaman et al. (2018) argue, in order to create structures that are more inclusive of the non-religious and to advocate for non-religious rights, it is necessary to examine the power and privilege still held by religions. Part of this power is held within residual religious social influence on laws and local social structures. This task is important from a sociology of religion perspective, because there are a growing number of non-religious people in many parts of the world and there is evidence that the overtly non-religious are persecuted due to societal norms around 'religion'.

The continued privileging of 'religion' is an issue because non-religious and atheist groups are becoming ever more present minorities in many societies (Keysar and Navarro-River 2017). For example, the British Social Attitudes Survey (Curtice et al. 2019) found that in the UK there has been a "substantial increase in atheism and in self-description as 'very' or 'extremely' non-religious." The survey found that $52 \%$ of the UK population now claim they do not belong to a religion, up from $43 \%$ in 2008. New Zealand has seen a similar trend, with the 2018 census finding that $48.2 \%$ of New Zealanders say they have no religion (Stats NZ 2019), up from 41.9\% in 2013. Stats NZ (2019) adds that "those with no religion outnumber those affiliated with at least one religion". While not as strong as the previous two cases, Australia has also seen a dramatic increase in the non-religious, from $22.3 \%$ in 2011 to 30.1\% in 2016 (Australian Bureau of Statistics 2017). Even the US, often cited as a case against secularisation, has seen a significant rise in the atheist, agnostic and non-religious people, from $16 \%$ in 2007 to 26\% in 2019 (Pew Research Center 2016a, 2016b, 2019). In a last example, there has even been an increase in non-religion in many Middle Eastern and North African (MENA) countries, with Arab Barometer (BBC 2019) finding an overall increase in non-religion from $8 \%$ to $13 \%$ across the MENA region from 2013 to 2019.

Adding to this, there is increasing evidence that atheist and non-religious people face discrimination for openly expressing their beliefs. For example, Gervais et al. (2017) argue that there is evidence from around the globe that supports the presence of prejudice against atheists. Their findings suggest that the perceived influence of religions on morality is in large part responsible for such prejudice. They also find that prejudices affect employment, elections, family life and social inclusion. Due to this, the non-religious are sometimes coerced into religious behaviour and participation, or experience discrimination for not participating, even in relatively open/liberal societies. This allows the maintenance of informal religious privilege in many societies. For example, Gervais et al. (2011) and Swan and Heesacker (2012) found that informal religious privilege is maintained in the US through anti-atheist prejudice, because people in the US distrust those who do not believe in god(s) (also see Cragun et al. 2012; Hammer et al. 2012). Adding to the structural mechanisms behind such discrimination, Edgell et al. (2016) show that prejudice stems from informal tendencies to see atheists as immoral due to US cultural values that connect religion and morality to citizenship and national identity. Beaman et al. (2018) demonstrate through Canadian cases that non-religious people are informally and formally coerced into religious identification and practices through the privileged access to resources currently available to religions. In Australia, I (Nixon 2016) used the case of the atheist bus campaign to illustrate informal prejudice through the refusal to advertise atheist views. Finally, in the UK, Giddings and Dunn (2015) found robust anti-atheist prejudice, suggesting that even where large non-religious populations exist, informal prejudice against atheists was present.

Coercion can be even more severe outside of these societies. In some countries, non-religious rights are not just unrecognised, but actively opposed as is the case in Afghanistan, Egypt, Indonesia, Malaysia, Pakistan and Saudi Arabia (Angeletti 2012; Carpenter 2017; Humanists International 2017a, 2018a; Johnson 2014; Nixon 2018). This creates a situation where the non-religious are actively coerced into maintaining a religious façade, through both formal and informal sanctions. There are an increasing number of claims of persecution in these regions (also see Nixon 2018). I have chosen three cases from 2017 to discuss as examples, due to their relatively recent nature, but with enough time having passed to confirm the cases and the consequences involved. Firstly, Ayaz Nizami, the vice president 
of Atheist $\mathcal{E}$ Agnostic Alliance Pakistan (AAAP) was arrested, along with two other bloggers. Nizami has been imprisoned just for organising Pakistani Atheists, accused of blasphemy for receiving and disseminating 'blasphemous content' which he allegedly translated into Urdu from European sources (Council of Ex-Muslims of Britain 2017). The hashtag \#HangAyazNizami became a top trend on social media at the time of the accusations (Hodgart 2017; Mehta 2017; National Secular Society 2017). Therefore, informal discrimination added to and encouraged formal government actions against Nizami and he now faces the death penalty. In the second case, Malaysian Atheists were targeted by government officials after a picture was posted on the Malaysian Atheist Republic Facebook page, outing many hidden members (Zurairi 2017). Atheist Republic is the biggest atheist group on Facebook, supporting some of the most vulnerable atheists in the world. The Malaysian government requested that Facebook ban Atheist Republic pages but the request was denied by the company (Lena 2017). The Malaysian branch was accused by the Malaysian government of attacking religions in an aggressive way. A deputy minister in the prime minister's department claimed that there was no place or rights for atheists in Malaysia or their constitution, a claim later disputed by lawyers (USCIRF 2018). Another cabinet minister proclaimed that 'atheism is a very dangerous ideology' that was being 'spread by social media' and that the government would 'hunt them down' (Humanists International 2017b). The minister claimed that Malaysia has freedom of religion, but not freedom from religion (USCIRF 2018). In the third and final case of the same year, Saudi Arabian Ahmad Al-Shamri was sentenced to death on charges of blasphemy and being an atheist, after posts he had made on social media in 2014 (McKernan 2017). Saudi Arabia has declared all atheists to be terrorists who can be given the death penalty as of 2014. It is therefore very dangerous to be accused of atheism in the Kingdom. Hala Dosari, who is on the advisory board of Human Rights Watch told The Washington Post that Al-Shamri's trial focused heavily on Quranic law and little on any mitigating mental illness, despite Al-Shamri claiming that he had been mentally ill at the time of the posts and was not actually an atheist (Wootson 2017). The Twitter hashtag حفرالباطن_مرتد (English translation 'apostate from Hafar Al-Batin') was used to tweet both support for the government decision and support for Al-Shamri against the government. The hashtag again illustrates the informal discrimination behind formal government actions (Humanists International 2018b). A number of emerging cases also suggest that non-religious asylum claims are on the rise, although it is difficult to find official data to strengthen these assertions (see Nixon 2018).

The continuation in coercion/persecution and the rise in asylum cases suggests that something is amiss with human rights protections being provided to the non-religious (Jamal 2015; Nixon 2018). This paper examines such treatment in the context of human rights instruments and laws. It examines the extent to which state actors have or have not ignored human rights standards in their persecution or deprivileging of non-religious people. It does so through a three-step analysis. Step 1 is to examine the aspirational Universal Declaration of Human Rights (UDHR). This paper will examine the relevant sections of the UDHR and interpretations that they have received. Step 2 is to do the same with the binding International Covenant on Civil and Political Rights (ICCPR). Finally, Step 3 is to do the same with lower-level and local laws, where I shall examine the extent to which individual countries' laws and practices toward non-religious people support or contradict the treaty commitments that those countries have made.

\section{Article 18 and 19 of the UDHR and Protection of '(Non)Religion'}

The UDHR (Universal Declaration of Human Rights) is a non-binding aspirational rights document that was created in the aftermath of WWII and the events of the Holocaust. It contains a number of articles that are of relevance to the rights of non-religious people. However, whether these rights do apply to non-religious people is not entirely clear. This factor adds to the non-binding nature of the UDHR to allow some ambiguity within this document around protection of the non-religious and their right to expressing and practicing their beliefs. Three articles are of particular interest to this analysis; Article 18 that protects the freedom of thought, conscience and religion; Article 19 that 
protects freedom of opinion and expression; and Article 29 a general limitations clause which applies to all rights and freedoms in the declaration.

The UDHR's Article 18 states that:

Everyone has the right to freedom of thought, conscience and religion; this right includes freedom to change his religion or belief, and freedom, either alone or in community with others and in public or private, to manifest his religion or belief in teaching, practice, worship and observance.

The UDHR uses the phrase 'religion or belief' to signify the freedoms to be protected. On a simple reading of the article, any interpretation that restricts the scope of Article 18 to protecting only religious beliefs would make the addition of "or belief" seem redundant. Heiner Bielefeldt, the United Nations Special Rapporteur for Freedom of Religion or Belief (2010-2016) supports this reading. In an article from 2012, he argues that if human rights are to function as the normative reference in international law, the notions of agency and dignity cannot be claimed by any single tradition. For example, he suggests that this reading is supported by the fact that proposals to base UDHR definitions of human dignity on the Biblical idea that humanity has been 'created in the image and likeliness of God' were rejected by the majority of delegates. In Bielefeldt's (2012) reading, this indicates an awareness that concepts in human rights instruments must remain open to multiple religious and non-religious traditions.

However, Lindkvist (2013) suggests that "one of the basic features of this articulation [of Article 18] - the distinction between inner and external liberty - is best explained in light of the direct and indirect influences of Christian personalism on the drafting process." Lindkvist (2013) claims that UDHR Article 18 was the work of a few people who saw individual rights to freedom of conscience and belief as the essence of religious freedom in 1948, rather than collective/minority rights to practice or avoid practices. For example, Turkey's ban on wearing the Hijab could be seen as a minor limitation of religious liberty because it left the individual's freedom of belief intact. He argues that this formulation largely arose from the interests of Christian actors who wished to counter a strawman version of Islamic intolerance of conversion and retain the right to evangelise (Lindkvist 2013). As Mahmood (in Asad et al. 2013) reminds us, the concept of religion as a matter of individual choice and belief is a distinctly Protestant way of conceiving of religion. Thus, the ambiguity of the original text means that it is possible to argue that the text was written in an era in which the drafters thought of religion as primarily about religious belief, and conversion to other beliefs. It could therefore be interpreted as protecting only religious belief, not necessarily extending to unbelief.

As a counterpoint, Bielefeldt (2012, p. 23) argues, with particular relation to the non-religious, that plurality should also imply equal concern for both 'positive' freedom and 'negative' freedom. In this interpretation, the non-religious must also be free not to engage in religious ideas and practices; a 'negative' dimension of freedom of religion or belief. This dimension could include the freedom from religion or belief, or to be indifferent about religious or philosophical issues (Bielefeldt 2012). He thinks that what counts in human rights instruments is the self-understanding of humans on what 'religion or belief' entails. He suggests that such broad definitions must be the starting point for defining freedom of religion or belief as a universal human right, due to the variety of religions, philosophies and beliefs present in human societies. In this view, the scope of these rights must be very broad.

Freedom of choice and freedom to convert both work in favour of the non-religious, and other new minority faiths, who need both of these rights to remain protected. Even if the original framers came from a particular perspective in arguing for freedom of choice and conversion, diversity of religion is aided by this framing. In this reading, 'belief' should necessarily include non-religious convictions, a stance that is also backed up on reading the literature and interpretations around the ICCPR as discussed below.

A second part of the UDHR can be seen as related to the rights of the non-religious, as it is the right that could allow the non-religious to express their arguments against the religions that they have rejected. This right to freedom of opinion and expression has been considered vitally important since the founding of the United Nations. UDHR (Article 19) states that: 
[e]veryone has the right to freedom of opinion and expression; this right includes freedom to hold opinions without interference and to seek, receive and impart information and ideas through any media and regardless of frontiers. (Eltayeb 2010; UDHR Universal Declaration of Human Rights)

The UDHR aims to allow individual expression and an unobstructed flow of information (Eide et al. 1992). Article 19 enables a liberal freedom without any limitations, with only one draft of the UDHR containing any limitations within the article (Glendon 2001, pp. 271-314). However, Article 19 does maintain a clear distinction between freedom of opinion and freedom of expression. Freedom of opinion is subject to no limitations, while freedom of expression is subject to certain restrictions (Eltayeb 2010). Such restrictions and the ability to interpret their application can work to limit the expression of the non-religious, as will be explored through the ICCPR below.

The UDHR also contains a general limitation clause in Article 29 which applies to all rights and freedoms in the declaration (Eltayeb 2010; Johnson 2014). It limits the right to expression by stating that:

everyone shall be subject only to such limitations as are determined by law solely for the purpose of securing due recognition and respect for the rights and freedoms of others and of meeting the just requirements of morality, public order and the general welfare in a democratic society. (Eltayeb 2010; Johnson 2014)

However, Article 29 leaves out guidance on what meets the requirements of the limitations discussed in the article. On a surface reading of UDHR article 29, a state could have a law restricting expression as long as the goal was to respect others' freedoms, public morality, public health, and public order. This is where some of the ambiguity around non-religious expression can be seen, since this reading seems to allow for the restriction of non-religious expressions if the state decides that restrictions meet these requirements. Article 29 flags some of the same limitations on expression as ICCPR Article 19 (3), discussed below.

\section{Article 18 of the ICCPR: Protecting 'Non-Religion' as 'Belief'}

The ICCPR emerged after the completion of the UDHR as the Human Rights Committee (HRC) began to press for a binding covenant to enforce the aspirational rights found in the UDHR (Eltayeb 2010; Johnson 2014). Unlike the UDHR, it is a binding treaty, which compels ratifying countries to protect human rights, making it important to discuss as a separate document.

Article 18 (1) of the ICCPR states that:

Everyone shall have the right to freedom of thought, conscience and religion. This right shall include freedom to have or to adopt a religion or belief of his choice, and freedom, either individually or in community with others and in public or private, to manifest his religion or belief in worship, observance, practice and teaching.

Like the UDHR, the ICCPR uses the phrase 'religion or belief' to denote the freedoms to be protected. The drafting history of the ICCPR supports a reading that includes the protection of non-religion under the category of 'belief'. For example, many countries objected to initial drafts without the 'or belief' language, largely because they did not cover non-religious convictions (Lerner 2012). The same phrase was found in an influential study preceding the drafting process, which deliberately framed the language as including religious beliefs and "such other beliefs as agnosticism, free thought, atheism and rationalism" (Krishnaswami 1960). The drafters' intentions seem to have been the protection of both religious and non-religious beliefs.

Human Rights Committee (HRC) jurisprudence on the scope of 'religion or belief' also confirms that non-religious beliefs are protected under Article 18 of the ICCPR. For example, in the case Leirvag v. Norway (2004), Unn and Ben Leirvag, objected to their child being forced to participate in religious instruction, arguing it was in violation of their Article 18 rights. The HRC agreed with their 
assessment and stated that the "scope of article 18 covers not only protection of traditional religions, but also philosophies of life, such as those held by the authors." (Carpenter 2017, p. 225).

HRC General Comments (GC) and other reports on the scope of 'religion or belief' also give the same impression. HRC GC 22 Paragraph 5 combines earlier stances and confirms that atheistic views are included. It states that:

The Committee observes that the freedom to 'have or to adopt' a religion or belief necessarily entails the freedom to choose a religion or belief, including the right to replace one's current religion or belief with another or to adopt atheistic views, as well as the right to retain one's religion or belief. (HRC Human Rights Committee)

Furthermore, HRC GC 34 says that it is "impermissible" for any law to "discriminate in favour of or against ... religious believers over non-believers." (HRC Human Rights Committee). HRC GC 22 Paragraph 3 adds that ICCPR Article 18 does not permit any limitations on this right (OHCHR Office of the High Commissioner of Human Rights). Carpenter (2017, p. 226) cites other reports that include atheists, agnostics and freethinkers as being protected under Article 18 and HRC comments on instances of discrimination against the non-religious.

Coercion away from atheism or non-religion is also barred within human rights instruments. Both the ICCPR Article 18 (2) and the 1981 Declaration of the General Assembly Article 1 (2) state that: "No one shall be subject to coercion which would impair his freedom to have or to adopt a religion or belief of his choice" (OHCHR Office of the High Commissioner of Human Rights). HRC GC 22 Paragraph 5 extends these statements by providing specific cases that are barred and adds the non-religious specifically into the coverage of ICCPR Article 18 (2), stating that the article:

... bars coercion that would impair the right to have or adopt a religion or belief, including the use of threat of physical force or penal sanctions to compel believers or non-believers to adhere to their religious beliefs and congregations, to recant their religion or belief or to convert. Policies or practices having the same intention or effect, such as, for example, those restricting access to education, medical care, employment or the rights guaranteed by article 25 and other provisions of the Covenant, are similarly inconsistent with article 18 (2). The same protection is enjoyed by holders of all beliefs of a non-religious nature. (OHCHR Office of the High Commissioner of Human Rights)

Therefore, we can clearly see that when viewed in accordance with the rules of good faith interpretation (Vienna Convention 1969; ICCPR Article 5 (1)), non-religious beliefs are protected by binding human rights instruments such as the ICCPR. On deeper readings of the interpretations of the ICCPR, it becomes clear that Article 18 should provide as much right to adopt, have and change to non-religious and atheistic views as to any other religion. The idea that Article 18 protects manifestations of non-religious beliefs is therefore based on a broad consensus (Carpenter 2017). The non-religious should also have these rights without being subject to laws and actions that attempt to coerce them away from their non-religious stance. Read together and harmoniously, this suggests that any country that allows the exclusion or coercion of non-religious groups would be in breach of Article 18. However, ICCPR Article 19 and 20 make this interpretation more ambiguous and allow some to argue that certain non-religious expressions and behaviour can be limited.

\section{Articles 19 and 20 of the ICCPR: Limiting Non-Religious Expression}

A major issue for the non-religious, in comparison to the religious, lies in the fact that some forms of expression may be viewed as incompatible with international law values, and therefore not able to benefit from protections. This is because some non-religious expressions are more like criticisms of religious beliefs than a belief in itself. This means that such expressions while at times problematic, can at other times be misinterpreted as hate speech or incitement to hatred, even where critiques are arguably legitimate. There are reasons for these restrictions. For example, in the case of Norwood 
v. the United Kingdom, the distribution of posters by a member of an extreme right-wing group that linked Islam with terrorism was deemed a 'vehement attack on a religious group.' It was judged as 'incompatible with the values proclaimed and guaranteed by the convention, notably tolerance, social peace and non-discrimination'. Therefore, the court found that it did not benefit from protection (Evans 2009).

The maintenance of peaceful coexistence in multicultural societies requires governing bodies to uphold a balance between freedom of expression and freedom of religion, since these rights coexist with each other (Eltayeb 2010). Allowing for diversity means that there must be exchanges of ideas, but these expressions may be unwelcome and offensive to some groups. Protecting expression allows the realisation of pluralism yet runs the risk of compromising the values and practices of some groups due to competing rights around certain issues. For example, discussions around the idea of 'Islamophobia', often conflate legitimate criticism of arguably discriminatory Islamic values and practices (which are also held and enacted by many other religious groups) such as homophobia, sexism, ritual slaughter of animals and anti-atheist sentiments, with assaults on the right to hold religious convictions (Bleich 2011; Halliday 1999; Imhoff and Recker 2012; Nixon 2019; Malik 2009; Zúquete 2008). Framing non-religious expression in this way, as Islamophobia, can be problematic. Because while society has become used to accepting the idea that religious truth claims can reject the rights of others, we have often not yet accepted non-religious truth claims as having equal validity (Beaman et al. 2018; Imhoff and Recker 2012). This framing can therefore have a chilling effect on the ability of the non-religious to express their reasons for disagreeing with, disbelieving in, or for leaving a religion.

Due to this tendency to limit non-religious expressions, it is necessary to analyse the relevant ICCPR articles governing freedom of opinion and expression. The discussion will start with ICCPR Article 19 which states:

1. Everyone shall have the right to hold opinions without interference.

2. Everyone shall have the right to freedom of expression; this right shall include freedom to seek, receive and impart information and ideas of all kinds, regardless of frontiers, either orally, in writing or in print, in the form of art, or through any other media of his choice.

3. The exercise of the rights provided for in paragraph 2 of this article carries with it special duties and responsibilities. It may therefore be subject to certain restrictions, but these shall only be such as are provided by law and are necessary:

(a) For respect of the rights or reputations of others;

(b) For the protection of national security or of public order (ordre public), or of public health or morals.

ICCPR Article 19 (3) (a) and (b) contain the restrictions which some commentators and governments argue can be used to limit non-religious expression. The Article flags the same restrictions as UDHR article 29. Its inclusion means a state could have a law restricting expression, as long as the goal was to respect others' freedoms, public morality, public health and public order, allowing the potential for restriction of non-religious expressions. For example, blasphemy laws are often instated for the purpose of protecting the religious freedoms of majority groups (others), religious morality, and public order (due to violent reactions or the perception that religion is necessary for public order). Bielefeldt (2012) and Carpenter (2017) suggest that such interpretations ignore the idea that non-religious expressions might qualify as manifestations of belief under Article 18. Despite this, the ICCPR does allow more restrictions to be placed on freedom of expression (Eltayeb 2010; Johnson 2014). These restrictions can therefore be used against non-religious expression and require further analysis.

The first case, ICCPR article 19 (3) (a), which relates to respecting the rights and freedoms of others, can potentially be used to protect religious leaders and religions from reputational damage. However, HRC GC 34 (paragraph 48) indicates that this type of comment can only be restricted under limited circumstances (Angeletti 2012; Johnson 2014): 
Prohibitions of displays of lack of respect for a religion or other belief system, including blasphemy laws, are incompatible with the Covenant, except in the specific circumstances envisaged in article 20 par. 2 of the Covenant. Such prohibitions must also comply with the strict requirements of article 19, paragraph $3(\ldots)$ nor would it be permissible for such prohibitions to be used to prevent or punish criticism of religious leaders or commentary on religious doctrine and tenets of faith

In line with HRC GC 34, ICCPR Article 19 (3) (a) is not intended to protect religious leaders or religious doctrine from criticism. Restricting non-religious speech for the purposes of protecting religious feelings would therefore seem unacceptable once this clarification from the HRC is taken into account.

With relation to ICCPR Article 19 (3) (b), the first condition is that of public morality. Protection of "public morals" can be used as a justification for restricting the right to freedom of expression as long as the restriction meets the conditions in 19 (3) of the ICCPR. However, in GC 34, the HRC stated:

The Committee observed in general comment No. 22, that "the concept of morals derives from many social, philosophical and religious traditions; consequently, limitations ... for the purpose of protecting morals must be based on principles not deriving exclusively from a single tradition". Any such limitations must be understood in the light of universality of human rights and the principle of non-discrimination.

According to this comment, laws that protect morality are not intended to be derived from a specific religious tradition. However, apostasy and blasphemy laws are often designed to protect specific traditions and therefore infringe on the rights of religious minorities and the non-religious. Bielefeldt (2012) suggests that laws stemming from a particular tradition often derive from a paradoxical combination of fear and contempt for a minority. Such minorities are also often depicted as lacking in moral values. Fear can even intensify and build towards political paranoia and conspiracy theories (as seen around atheists in Egypt and Saudi Arabia). These escalations often target small minorities who are portrayed as having 'infectious' power which allegedly threaten social cohesion. Bielefeldt (2012) argues that on the side of majority society, this fear and contempt, leads to aggressiveness from a feeling of vulnerability and from the perception of moral superiority. These factors are seen in the classic idea of a moral panic (Cohen 2011). This is particularly the case for the non-religious, who are painted as a 'dangerous phenomenon' that damages the fabric of society through their perceived lack of morality (Humanists International 2018b; Johnson 2014; Marshall and Shea 2011; USCIRF 2018). Laws based on a particular tradition and targeting specific minorities therefore do not seem to meet the HRC GC 34 requirement of the universality of human rights and the principle of non-discrimination.

In the second condition of ICCPR Article 19 (3) (b), restrictions may apply for reasons of 'public order'. Many of the issues with public order that form around non-religious expression are found in the often violent reactions against it (Carpenter 2017). Citing previous decisions of the HRC, Carpenter (2017) argues that in cases based on public order, the HRC should consider a state's actions when deciding if a limitation was necessary. For example, did authorities engage in actions that attempted to calm or stop the responses to non-religious expression that brought about the disorder? He argues that if such actions have not been taken, the HRC should not accept the restrictions as based on necessity (Carpenter 2017, p. 240). ICCPR Article 27 (Protection of minorities) also supports this reading since it prohibits the denial of a minority group's ability "to profess and practise their own religion," which as established earlier would include non-religion. Adding to this, ICCPR Article 26 (Equality before the law) states that the law must "guarantee to all persons equal and effective protection against discrimination on any ground," which would include non-religious status. Non-religious rights cannot be ensured if the HRC finds limitations permissible because of violent reactions from a religious majority. The threat of violence would essentially bar a non-religious minority from manifesting its beliefs. Thus, in cases where a state limits non-religious expression due to public order issues linked to 
violent reactions, the HRC should reject the response because the result would be the destruction of freedom of expression for the non-religious minority (Carpenter 2017).

HRC GC 34 states that ICCPR Article 19 and Article 20 work together to complement each other. Article 20 also contains further restrictions to expression, for both the state and individuals/groups within a state. The article directly mentions both propaganda and advocacy of religious hatred. The HRC also expressly indicates the article as needing direct legal action, with parties to the ICCPR obliged to adopt legislative measures prohibiting actions referred to in the article (Eltayeb 2010). For this reason, Article 20 is seen as more controversial than the other articles, because it involves government control of expression, which in turn could enable abuse of that control. All of these factors make it relevant to issues surrounding non-religious freedom and expression and therefore it must also be discussed. The Article states that:

1. Any propaganda for war shall be prohibited by law.

2. Any advocacy of national, racial or religious hatred that constitutes incitement to discrimination, hostility or violence shall be prohibited by law.

The drafting history of Article 20 reveals considerable discussion on the consequences of the article's wording. Disagreements around Article 20 involved two main issues: the potential abuse of restrictions by governments and the problems with defining the terms 'incitement', 'hostility' and 'hatred'. The issue of non-religious truth claims often resembling criticism of religions and religious practices also arises through this article. These forms of non-religious expression could be considered as either propaganda or incitement to discrimination, hostility or violence. The ambiguity and diversity of views around what is hostile to a particular religion could allow these expressions to fall within valid restrictions. If non-religious expression is framed in this way, it can have broad consequences in theocratic states, due to monopoly and claims to superiority by the state religion. These factors may lead to harassment and punishment of individuals and groups who do not follow the state's official position (Eltayeb 2010).

However, in GC 11, the HRC argues that the prohibitions under Article 20 (1) extend to all forms of propaganda, whether it has aims internal or external to the State. Furthermore, they state that the measures contemplated by Article 20 (2) are safeguards designed to protect against acts of violence and persecution directed at minority religious groups. It is intended to allow such groups to exercise the rights guaranteed by Articles 18 and 27 (minority rights) of the ICCPR. When GC 11 is taken into account, and the protection of non-religion under Article 18 is recognised, state propaganda against the non-religious should also be seen as problematic. Internal laws and propaganda against the non-religious would run directly counter to the need for active laws that protect against hate speech and persecution of particular groups.

In order to be legitimately restricted, speech acts should also satisfy the criteria set forth by Article 20 (2) of the ICCPR. This means they must be shown to advocate for actions that constitute 'incitement to discrimination, hostility or violence' (Angeletti 2012; Eltayeb 2010; Johnson 2014). Neither the drafting history of Article 20 nor HRC GC 11 have defined this phrase. The HRC jurisprudence regarding Article 20 (2) also says little on the definition of religious hatred that amounts to incitement. It does not specifically tell the states what speech they can and cannot restrict. There is also no stronger definition in any other international law document (Johnson 2014). The Camden Principles do try to clarify the definition. They add in Principle 12.1 (i) that "'hatred' and 'hostility' refer to intense and irrational emotions of opprobrium, enmity and detestation towards the target group." They also clarify the terms "advocacy" and "incitement," as being statements that generate an "imminent risk of discrimination." This definition is still broad and could really include whatever a state decides is relevant (Johnson 2014).

While GC 34 specifically protects even 'deeply offensive' speech, it also states that such speech may be prohibited in accordance with the provisions of Article 19 (3) (Angeletti 2012; Johnson 2014). This means that states may use the wording around the reputation of others, and public order, 
public health, and public morality as reasons to prohibit certain forms of expression. However, even where restrictions are deemed necessary under Article 20, they cannot favour religious believers over non-believers (HRC Human Rights Committee, para. 48), even if the expression is regarded as "deeply offensive" (HRC Human Rights Committee, para. 11), or if such restrictions are "enshrined in traditional, religious or other such customary law." (HRC Human Rights Committee, para. 24). The Special Rapporteur on freedom of religion or belief (Heiner Bielefeldt 2010-2016) also puts forward that disturbing and shocking speech should not be conflated with speech that amounts to incitement of hatred (Carpenter 2017; UN United Nations). In the document (UN United Nations), the Special Rapporteur states that only expressions that incite imminent acts of violence or discrimination against a specific individual or group should be prohibited under Article 20 (2). Adding to these insights, the drafting history of Article 20 suggests that it was designed to restrict only the most extreme types of hateful expression (Carpenter 2017; Eltayeb 2010). Read together, these documents indicate that speech against religions may be considered offensive or insulting by people, but still not necessarily result in violation of the right to freedom of religion (Carpenter 2017; Eltayeb 2010). Mere criticism without a specific call to violence or discrimination would not fit within the definition of incitement via hate speech. GC 34 also specifically excludes blasphemy laws as being incompatible with the article, except in cases where such speech contravenes Article 20 (amounts to propaganda or hate speech). So, while on the surface it is increasingly difficult to see how blasphemy laws can be compatible with the human rights framework (Angeletti 2012; Evans 2009; Johnson 2014), the inclusion of Article 20 allows some government leeway to label certain speech as prohibited.

Carpenter (2017) suggests that it is unlikely that people sanctioned for non-religious expressions had the intention of inciting immanent discrimination, hostility or violence. This is because the non-religious are still mostly in the minority and are often the targets of discrimination and violence due to their speech. The examples of non-religious expression are also often criticisms of religious views that are accepted by those advocating for human rights, such as criticisms of homophobia or sexism. Moreover, much non-religious expression simply states a lack of religion, representing their own belief rather than an attack on a specific individual or group. Even if the HRC allows a religion to qualify as a targeted group and views non-religious expression as advocacy of hatred, the status of the targeted group must surely also be considered. In this framing it is implausible that a non-religious minority, could realise the impairment of rights of a powerful religious majority. If majority feelings are allowed to stifle minority non-religious expression, it encourages violent reactions. This is because, if permitted, such actions allow the majority group to both remove expression distasteful to them and support their group's identity against a common enemy (Carpenter 2017).

The issues discussed here apply to both minority religions as well as the non-religious. They emphasise the idea that freedom of religion and belief, and freedom of expression are closely related legal safeguards of communicative freedom (Bielefeldt 2012; Eltayeb 2010). The religious require freedom of expression just as much as the non-religious, especially when they are not part of the majority or have been given the designation 'not religious' by that majority. As has been shown here, in human rights instruments the burden of proof always falls on those wishing to enact restrictions. Despite this, there is some leeway for restrictions to be enacted. States continue to tightly restrict non-believers, are involved in propaganda against them, and often harshly punish them for expressing or manifesting their beliefs (Carpenter 2017).

\section{Local Interpretations of Non-Religious Rights: Inclusion and Exclusion}

Even with the protections found within international human rights instruments, the protections extended to religions and non-religion vary by region and legal system. The general consensus in the international agreements has therefore often not been carried down to the level of local laws and culture (Carpenter 2017; Gunn 2002; Hale 2017; Humanists International 2017a, 2018a; Johnson 2014). Campaigns and laws discriminating against or excluding the non-religious continue to be features of many states and many of these states are also signatories to the ICCPR (Johnson 2014). 
Specific to the non-religious, Bielefeldt (2012) and Carpenter (2017) both suggest that many individuals and governments are unaware that freedom of religion or belief covers the non-religious, atheists and agnostics. This lack of awareness and clarity about non-religious rights is reflected in the exclusion of non-religious views from 'religion' in many legal contexts. As observed by Nicolas Bratza, a former President of the European Court of Human Rights (ECHR), achieving a definition of 'religion' that is flexible enough to cover the range of world religions but also precise enough for practical application is difficult (cited in Tulkens 2014). Academics have the distance from practical application to consider whether 'religion' can or should be defined. But this is not the case for national governments and persecution/asylum adjudicators, who must interpret the meaning of 'religion'. However impossible it might be, or how inadequate the adjudicator's skillset, the legal system requires them to do so. The meaning of 'religion' is therefore a legal question that is addressed differently in different legal and cultural regimes (Behrman 2014; Gunn 2002). The necessity of defining 'religion' is particularly problematic because 'religion' is not a value-free description of beliefs or practices. It is a value judgment on the particular beliefs or actions, which defines them into something that is acceptable or unacceptable to a society or a legal system (Gunn 2002). However, we also cannot consider just any opinion as having the status of a serious belief, because freedom of religion or belief would lose significance and applicability. Deciding on the correct place to draw the line is difficult and dealing with this issue requires careful consideration (Hale 2017).

The range of legal understandings of 'religion' can be very broad (as in India and the EU) to very narrow (as in Saudi Arabia). The ECHR is the case that Storey (2014) suggests as a paradigm of protections against religious persecution. The court has tended to favour a broad and imprecise definition of 'religion'. These wide protections have enabled European courts to apply the criteria not merely to long-established religions, but also to newer and less common forms of religious movements. The ECHR also specifically includes a wide range of non-religious beliefs, including atheism and humanism. Thus, in the European case, any suitably conscientious system of beliefs could be seen as a 'religion' (Tulkens 2014). As demonstrated in ECHR Article 10 (1) (b):

the concept of religion shall in particular include the holding of theistic, non-theistic and atheistic beliefs, the participation in, or abstention from, formal worship in private or in public, either alone or in community with others, other religious acts or expressions of view, or forms of personal or communal conduct based on or mandated by any religious belief

This is a very broad understanding of the concept of 'religion'. It confirms the idea that the concept is not confined to organised, long-standing religions and it deliberately includes atheists as part of the category. However, as Hale (2017) argues, ideas and practices traditionally seen as 'religion' are still likely to qualify for automatic protections in the ECHR, where non-religious belief systems may have to exhibit certain criteria within the scope of ICCPR Article 18 to merit protection. Hale (2017) illustrates a belief that would not qualify through the example of pacifists distributing leaflets to troops to dissuade them from serving in the armed forces. This particular illustration was confirmed in Europe by the case of Campbell and Cosans v. the United Kingdom which found that "the term 'belief' denotes views that attain a certain level of cogency, seriousness, cohesion and importance", discounting certain non-religious stances as qualifying. The case suggests that personally held ideas, opinions and beliefs may not fall within the definition of 'religion' (Evans 2009). So, even in the European case, there are still restrictions on what can qualify as a 'religion' for the purposes of attaining protections under freedom of religion laws.

The ECHR style of broad definition is not adopted in all national contexts. This is illustrated in other, generally more liberal, regions where we can see that the definition of religion is more exclusionary when considering non-religion and atheism. For example, Lord Toulson's 'working definition' adopted by the UK Supreme Court (cited in Hale 2017):

a spiritual or non-secular belief system, held by a group of adherents, which claims to explain mankind's place in the universe and relationship with the infinite and to teach its adherents 
how they are to live their lives in conformity with the spiritual understanding associated with that belief system. By spiritual or non-secular I mean a belief system which goes beyond that which can be perceived by the senses or ascertained by the application of science.

This specifically UK definition therefore shows the deliberate exclusion of scientific and secular worldviews which many non-religious people hold (also see UK cases Re South Place Ethical Society $1980^{1} ; R$ (on the application of Hodkin and another) v. Registrar of Births, Deaths and Marriages 2013) ${ }^{2}$. We can find similarly exclusionary legal definitions around the world, such as ideas related to the supernatural in Australia (Church of the New Faith v. Commissioner of Pay-Roll 1983) ${ }^{3}$, with relation to gods in Singapore (Nappali Peter Williams v. Institute of Technical Education 1999) ${ }^{4}$, or as related to individualised spirituality in Canada (Syndicat Northcrest v. Amselem 2004) ${ }^{5}$.

In other national contexts the definition and recognition of 'religion' can go well beyond simple legal exclusion, to a direct persecution of those who do not adhere to particular religious beliefs (e.g., Saudi Arabia, Indonesia, Afghanistan, Egypt: Humanists International 2017a, 2018a, 2018b, 2018c). Freedom of religion or belief abuses occur due to different motives, in different political regimes, and in various regions of the world. They are perpetrated in the name of national identity, for purposes of defending law and order and to protect religious truth claims (Bielefeldt 2012). In these contexts, non-believers may be treated as apostates or blasphemers, whom the state is duty-bound to punish. They can have their rights restricted through everything from denial of services, tax benefits or legal rights to forced religious participation, government/social harassment, 're-education', removal of children, imprisonment or the death penalty. This includes cases in Egypt, Saudi Arabia, Indonesia, Pakistan, Kazakhstan, the Maldives, Cameroon, Tunisia, the Philippines, Turkey, Poland, and Greece.

The issue can be seen most starkly in national apostasy and blasphemy laws. There are at least two major concerns around these laws: firstly, their vague formulations and terminology, which can allow abuses by individuals, groups and the state; secondly, their exclusivist construction, since many such laws only protect specific religions. Consequently, they are often used to target interpretations of religion not sanctioned by the state and therefore to intimidate non-believers or believers of other creeds. Indeed, Non-Government Organisations (NGOs) have reported cases where blasphemy laws have been used as revenge in personal disputes (Angeletti 2012). These issues can occur because it is both hard to identify the victims (usually a religious group, not an individual) and to demonstrate one's innocence. Thus, apostasy and blasphemy laws have a restrictive effect on the religious expression of minorities. Such laws can affect critics, dissenters, members of religious minorities and the non-religious (Bielefeldt 2012). This is especially problematic because what is considered apostasy or blasphemous speech varies significantly and what is considered sacred can be very different even between denominations of a broader religion. Humanists International (2018a) gives an overview of which countries punish apostasy and blasphemy by death, with prison time, or place legal restrictions on (non-) religious speech and thought.

Apostasy is the act of renouncing a religion or at least the perception that an individual has done so. The ambiguity of perception arises because categorising someone as an apostate relies on the local community or authority's judgments of what constitutes an 'official' version of religion, or a renunciation of a religion. Indeed, the person being accused of apostasy may not believe they are an apostate (as seen with the Alevi in Turkey and the Ahmadis in Pakistan). As of 2018, 22 countries criminalise apostasy. In 12 countries (Afghanistan, Iran, Malaysia, Maldives, Mauritania, Nigeria, Qatar, Saudi Arabia, Somalia, Sudan, United Arab Emirates, Yemen), 'apostasy' is in principle punishable by death (Humanists International 2018a). In six countries, it is punishable by imprisonment

\footnotetext{
Re South Place Ethical Society. 1980. 1 WLR 1565, [1980] 3 All ER 981. England

$R$ (on the application of Hodkin and another) v. Registrar of Births, Deaths and Marriages. 2013. UKSC 77. UK.

Church of the New Faith v. Commissioner of Pay-Roll. 1983. HCA 40; (1983) 154 CLR 120. Australia.

Nappali Peter Williams v. Institute of Technical Education. 1999. 2 SLR 529. Singapore.

Syndicat Northcrest v. Amselem. 2004. 2 S.C.R. 551, 2004 SCC 47. Canada.
} 
(Humanists International 2018a). In Morocco, Malaysia and Jordan, it is punishable by fines, flogging and deprivation of family rights, such as the right to child custody (Humanists International 2017a). According to Pew Research Center (2016c), more than one in ten nations (13\%) had laws or policies penalising apostasy.

Some countries, although lacking apostasy laws, frequently use blasphemy laws to persecute non-believers or believers of other religions (including non-religion). Humanists International (2018a) shows that blasphemy is punishable by death in six countries (Afghanistan, Iran, Nigeria, Pakistan, Saudi Arabia, Mauritania) and imprisonment in 40 countries. According to Pew Research Center (2016c), a quarter of the world's countries and territories (26\%) have anti-blasphemy laws or policies. Similar to apostasy, there is no clear legal definition of blasphemy. It means something different in most legal systems across the world. In fact, in the Muslim-majority states, where most of these laws are found, there is no common idea of what constitutes blasphemy. The codes around blasphemy have developed differently in each state (Johnson 2014).

For example, the new constitution of Egypt bans blasphemy and forms of 'insult,' as well as only permitting 'divine' or 'monotheistic' religions. The Egyptian Penal Code contains Article 98 (f) which prohibits using religion to "degrade any of the heavenly religions, or harm national unity or social peace." (Marshall and Shea 2011, p. 67; Humanists International 2018c). Egyptian law also contains the "doctrine of hisba which entitles any Muslim to take legal action against anyone he considers harmful to Islam." (Siddique and Hayat 2008, pp. 370-71). The doctrine gives people the ability to harass others, such as members of other sects of Islam, Judaism, or Christianity (Marshall and Shea 2011, p. 62). Egypt's government officials have also claimed the presence of 866 atheists and publicly called the presence of these atheists a 'dangerous development.' Following this, they have conducted national campaigns to combat the spread of atheism that include convicting atheists of blasphemy (Carpenter 2017; Humanists International 2018c). One example is Sherif Gaber, an Egyptian atheist who was arrested for Blasphemy in 2013 under Article 98 (f). On 16 February 2015, Gaber was found guilty and sentenced to a year in jail-after which, he went into hiding. On 5 May 2018, he was arrested again and imprisoned. On 1 October 2018, Gaber tweeted that there were two "different ongoing blasphemy charges" against him. As of 12 October 2018, according to Gaber's tweets, he was facing five felony charges, each punishable by up to 15 years in prison "ranging from blasphemy, insulting Islam, contempt of religion, supporting homosexuality, shaking the peace of the society and 'religious extremism'" (Gaber 2019). Egypt's constitution therefore violates stipulations within the ICCPR, which Egypt ratified in 1982, by enforcing restrictions outside of those allowed in Articles 19 and 20 and the related general comments (Johnson 2014).

Similar laws are found in other countries. Algeria's penal code prohibits insults against Islam or the prophet Muhammad (Angeletti 2012; Humanists International 2018e). Adding to this, Algeria's Information Code of 1990, prohibits publications that are "contrary to Islamic morals, national values, human rights"; it bans insults against "heavenly religions," which include Islam, Christianity and Judaism. Similarly, in Malaysia, blasphemy is prohibited in both state Shari'a statutes and federal law; Pakistan's penal code contains blasphemy laws (Angeletti 2012; Humanists International 2018d); and most extreme of all, Saudi Arabia goes so far as to proclaim all atheists as terrorists who can and have been punished with the death penalty (Humanists International 2018b). These examples show that a number of Muslim-majority states favour Islam and its protection over the individual's right to freedom of religion and expression (Johnson 2014; Asad et al. 2013). However, these issues can also be found in the West. For example, some European states (Bielefeldt 2012) and New Zealand (Humanists International 2018f) continue to have domestic anti-blasphemy provisions, and there are constitutional provisions barring atheists from holding public office in eight US states (Humanists International 2018g). As discussed in the last section, blasphemy laws are specifically barred in the ICCPR and its surrounding interpretive documents. Restrictions of religion or expression based in a single tradition are also not acceptable. Yet many of these examples suggest that laws are still being created and enforced with both of these factors included. 
Restrictions can come in the form of these formal apostasy and blasphemy laws that put limits on the expression of religious and non-religious minorities. Laws which specifically give explicit support to certain religions or outlaw certain types of expression. But, as discussed in the introduction, they can also come in the form of informal negative discourses and culturally based ideas about the non-religious or at least those who are labelled non-religious (as seen in places like the US, UK, Australia, Egypt, Malaysia and Saudi Arabia). Both are effective at silencing non-religious expressions, as they essentially prohibit speech that would be viewed as critical of religion, and open identification with non-religion. Such restrictions clearly have a negative effect on non-religious freedom of expression and belief, and therefore should not be allowed under international human rights instruments. So, despite the support for non-religious individuals and expression in international documents, the situation on the ground is far less clear.

\section{Conclusions}

A discourse that justifies more automatic rights to something called 'religion', while ignoring or punishing non-religious beliefs, should be seen as unsustainable in the broader context of human rights. This is particularly the case when a growing number of the world's population are declaring themselves to be non-religious. A view of the modern religious landscape in full breadth makes it hard to argue against the large diversity of 'religion' and the need to take this diversity into account in human rights frameworks. By necessity, protecting human rights requires us to allow the expression of new worldviews even if they are distasteful to us, as long as protections remain in place so that they in turn do not violate the rights and freedoms of others. This is a delicate balance at times, as discussed above in relation to balancing freedom of religion and freedom of expression.

International human rights instruments and their interpretations certainly do have the intention of providing protection for the non-religious. However, states can restrict or prohibit non-religious expression under ICCPR Articles 19 and 20 as a form of 'hate speech' or as endangering 'public morality' or 'public order'. Part of this issue occurs due to the difficult line between freedom of expression and freedom of religion, which while complementary rights, can also come into conflict. There is no doubt that incitement to religious hatred, hate speech and discrimination should be forbidden. This is necessary in order to guarantee people their right to freedom of conscience and religion. But it should apply equally to the religious and non-religious. The definition of 'hate speech' that leads to incitement changes over time. Changes have been seen from racial, religious, ethnic, or national hate speech to including gender, age, sexual preference, marital status, physical capacity and other categories over the years (Johnson 2014). Any definition of hate speech is therefore necessarily impacted by the place and time from which we are viewing it. In recent times, we have seen a rise in numbers of the non-religious, cases of non-religious persecution, and the persistence of laws facilitating such persecution. These factors should lead us to argue that definitions of hate speech must now include the non-religious as a potential target.

The persistence of informal cultures and formal structures that effectively persecute the non-religious in many parts of the world mean that these protections are not filtering down for the non-religious at the local level. The non-religious are therefore still subject to formal and informal exclusion, discrimination and persecution in many places. This is evidenced by the presence of discriminatory laws. For example, penal laws prohibiting leaving a religion (apostasy), against criticising religion and against expressing non-religious identities (blasphemy). But also include wide social consequences for openly declaring non-religious identity due to informal ideas about religion and non-religion. That something is amiss is evident through increases in both persecution cases and asylum claims involving the non-religious in the last decade or so. The key issue is not, therefore, a matter of available international protections, but the persistence of local laws and cultures that contribute to non-religious persecution.

This persistence suggests that more focus needs to be put on exposing and alleviating the local conditions that lead to persecution. There are clearly still many places where the rights of the 
non-religious are tenuous at best and overtly curtailed at worst. As Carpenter (2017) argues, the HRC must clarify its jurisprudence and reaffirm the commitment to protecting controversial minority rights and expression. This is a difficult task and may take some time, especially given the privileged space religion still occupies in many societies. It will also take deep consideration of the perpetually unsettled border between freedom of religion and expression. The local systems that do recognise persecution experienced by the non-religious should also review processes to ensure that non-religious asylum cases are being recognised and heard. This means that those countries that can provide protection should do so, especially while the international legal situation remains so ambiguous for non-religious people.

The power and privilege still retained by 'religion' must be examined and challenged to help build fairer and more equal societies that include a place for the non-religious (Beaman et al. 2018). Hence, there is currently a need to better understand and consider non-religious perspectives and issues alongside religious ones within the sociology of religion and by extension through law, rights, policy and education frameworks. We must continue examining and critiquing the negative social influences of religion and the continuation of vestigial religious legal structures. This will allow us to help alleviate some of the persecution being experienced by individuals and groups due to formal and informal religious power. It is a task that is important to the non-religious and religious minorities alike, since both sometimes find themselves being defined by those in power as holding illegitimate forms of belief. I hope this article can inform and encourage these engagements among sociologists, religious studies scholars, activists and lay-people interested in the treatment of non-religious peoples.

Funding: This research received no external funding.

Conflicts of Interest: The authors declare no conflict of interest.

\section{References}

Angeletti, Silvia. 2012. Freedom of religion, freedom of expression and the United Nations: Recognizing Values and Rights in the "Defamation of Religions" Discourse. Rivista Telematica 2. [CrossRef]

Asad, Talal, W. Brown, J. Butler, and S. Mahmood. 2013. Is Critique Secular? Blasphemy, Injury and Free Speech. New York: Fordham University Press.

Australian Bureau of Statistics. 2017. 2016 Census Data Reveals "No Religion" is Rising Fast. Available online: http://www.abs.gov.au/AUSSTATS/abs@.nsf/mediareleasesbyReleaseDate/ 7E65A144540551D7CA258148000E2B85?OpenDocument (accessed on 2 April 2018).

BBC. 2019. The Arab World in Seven Charts: Are Arabs Turning Their Backs on Religion? Available online: https://www.bbc.com/news/world-middle-east-48703377 (accessed on 26 September 2019).

Beaman, Lori, Cory Steele, and Keelin Pringnitz. 2018. The Inclusion of Nonreligion in Religion and Human Rights. Social Compass 65: 43-61. [CrossRef]

Behrman, Simon. 2014. Legal Subjectivity and the Refugee. International Journal of Refugee Law 26: 1-21. [CrossRef]

Bielefeldt, Heiner. 2012. Freedom of Religion and Belief-A Human Right Under Pressure. Oxford Journal of Law and Religion 1: 15-35. [CrossRef]

Bleich, Erik. 2011. What Is Islamophobia and How Much Is There? Theorizing and Measuring an Emerging Comparative Concept. American Behavioral Scientist 55: 1581-600. [CrossRef]

Carpenter, Devin. 2017. "So Made That I Cannot Believe": The ICCPR and the Protection of Non-Religious Expression in Predominately Religious Countries. Chicago Journal of International Law 18: 216-44.

Cohen, Stanley. 2011. Folk Devils and Moral Panics: The Creation of the Mods and Rockers. London: Routledge. First published 1972.

Council of Ex-Muslims of Britain. 2017. Details on the cases of Ayaz Nizami and Rana Noman. Available online: https://www.ex-muslim.org.uk/2017/03/details-on-the-cases-of-ayaz-nizami-and-rana-noman/ (accessed on 22 November 2018).

Cragun, Ryan T., B. Kosmin, A. Keysar, J. H. Hammer, and M. Nielsen. 2012. On the Receiving End: Discrimination Towards the Non-Religious in the United States. Journal of Contemporary Religion 27: 105-27. [CrossRef] 
Curtice, John, Elizabeth Clery, Jane Perry, Miranda Phillips, and N. Rahim, eds. 2019. British Social Attitudes: The 36th Report. London: The National Centre for Social Research.

Edgell, Penny, Douglas Hartmann, Evan Stewart, and Joseph Gerteis. 2016. Atheists and Other Cultural Outsiders: Moral Boundaries and the Non-Religious in the United States. Social Forces 95: 607-38. [CrossRef]

Eide, Asbjørn, Gudmundur Alfredsson, Göran Melander, Lars Rehof, Allan Rosas, and Theresa Swinehart, eds. 1992. The Universal Declaration of Human Rights: A Commentary. Oxford: Oxford University Press.

Eltayeb, Mohamed Saeed M. 2010. The Limitations on Critical Thinking on Religious Issues under Article 20 of ICCPR and its Relation to Freedom of Expression. Religion and Human Rights 5: 119-35. [CrossRef]

Evans, Malcolm. 2009. The Freedom of Religion or Belief and the Freedom of Expression. Religion and Human Rights 4: 197-235. [CrossRef]

Gaber, Sherif. 2019. @Mr_SherifGaber. Twitter. Available online: https://twitter.com/Mr_SherifGaber (accessed on 29 March 2019).

Gervais, Will M., Azim F. Shariff, and Ara Norenzayan. 2011. Do You Believe in Atheists? Distrust Is Central to Anti-Atheist Prejudice. Journal of Personality and Social Psychology 101: 1189-206. [CrossRef]

Gervais, Will M., Dimitris Xygalatas, Ryan T. McKay, Michiel van Elk, Emma E. Buchtel, Mark Aveyard, Sarah R. Schiavone, Ilan Dar-Nimrod, Annika M. Svedholm-Häkkinen, Tapani Riekki, and et al. 2017. Global evidence of extreme intuitive moral prejudice against atheists. Nature Human Behaviour 1: 0151. [CrossRef]

Giddings, Leah, and Thomas J. Dunn. 2015. The Robustness of Anti-Atheist Prejudice as Measured by Way of Cognitive Error. The International Journal for the Psychology of Religion 26: 124-35. [CrossRef]

Glendon, Mary Ann. 2001. A World Made New: Eleanor Roosevelt and the Universal Declaration of Human Rights. New York: Random House.

Gunn, T. Jeremy. 2002. The Complexity of Religion in Determining Refugee Status. UNHCR. Available online: https://www.unhcr.org/en-au/protection/globalconsult/3e5f2f7f6/complexity-religion-determiningrefugee-status-t-jeremy-gunn.html (accessed on 22 May 2019).

Hale, B. 2017. Freedom of Religion and Freedom from Religion. Ecclesiastical Law Journal 19: 3-13.

Halliday, Fred. 1999. 'Islamophobia' reconsidered. Ethnic and Racial Studies 22: 892-902. [CrossRef]

Hammer, Joseph H., Ryan T. Cragun, Karen Hwang, and Jesse M. Smith. 2012. Forms, Frequency, and Correlates of Perceived Anti-Atheist Discrimination. Secularism and Nonreligion 1: 43-67. [CrossRef]

Hodgart, K. 2017. \#HangAyazNizami is What Comes of Caving in to Clerical Rule. Available online: http: //www.atimes.com/article/hangayaznizami-comes-caving-clerical-rule/ (accessed on 22 November 2018).

HRC (Human Rights Committee). 1993. General Comment No. 22 on Article 18 from its 48 th Session. U.N. Documents. CCPR/C/21/Rev.1/Add.4 (July 20, 1993). New York: United Nations.

HRC (Human Rights Committee). 2011. General Comment No. 34 on Article 19 from its 102nd Session. U.N. Documents. CCPR/C/GC/34 (September 12, 2011). New York: United Nations.

Humanists International. 2017a. The Freedom of Thought Report 2017. Available online: https://fot.humanists. international/download-the-report/ (accessed on 22 May 2019).

Humanists International. 2017b. Atheism "Very Dangerous" and "Unconstitutional" Says Government Minister in Malaysia, Again, Wrongly. Available online: https://humanists.international/2017/11/atheism-dangerousunconstitutional-says-government-minister-malaysia-wrongly/ (accessed on 1 October 2019).

Humanists International. 2018a. The Freedom of Thought Report 2018: Open Data. Available online: https: //fot.humanists.international/data/ (accessed on 20 November 2018).

Humanists International. 2018b. 'Saudi Arabia'. The Freedom of Thought Report. Available online: https: //fot.humanists.international/countries/asia-western-asia/saudi-arabia/ (accessed on 22 May 2019).

Humanists International. 2018c. 'Egypt'. The Freedom of Thought Report. Available online: https://fot.humanists. international/countries/africa-northern-africa/egypt/ (accessed on 22 May 2019).

Humanists International. 2018d. 'Pakistan'. The Freedom of Thought Report. Available online: https://fot. humanists.international/countries/asia-southern-asia/pakistan/ (accessed on 22 May 2019).

Humanists International. 2018e. 'Algeria'. The Freedom of Thought Report. Available online: https://fot.humanists. international/countries/africa-northern-africa/algeria/ (accessed on 22 May 2019).

Humanists International. 2018f. 'New Zealand'. The Freedom of Thought Report. Available online: https://fot.humanists.international/countries/oceania-australia-and-new-zealand/new-zealand/ (accessed on 22 May 2019). 
Humanists International. 2018g. 'United States of America'. The Freedom of Thought Report. Available online: https:/fot.humanists.international/countries/americas-northern-america/united-states-of-america/ (accessed on 22 May 2019).

Imhoff, Roland, and Julia Recker. 2012. Differentiating Islamophobia: Introducing a new scale to measure Islamoprejudice and secular Islam critique. Political Psychology 33: 811-24. [CrossRef]

Jamal, Arif A. 2015. The Impact of Definitional Issues on the Right to Freedom of Religion and Belief. In Routledge Handbook of Law and Religion. Edited by Silvio Ferrari. London: Routledge, pp. 93-99.

Johnson, Eric M. 2014. Examining Blasphemy: International Law, National Security and the U.S. Foreign Policy Regarding Free Speech. The Air Force Law Review 71: 25-67.

Keysar, Ariela, and Juhem Navarro-River. 2017. A World of Atheism: Global Demographics. In The Oxford Handbook of Atheism. Edited by Stephen Bullivant and Michael Ruse. Oxford: Oxford University Press.

Kirby, M. 2009. Law, Human Rights and Religion-Of Genocide, Sexuality and Apostasy. Macquarie Law Journal 9: 3.

Krishnaswami, Arcot. 1960. Study of Discrimination in the Matter of Religious Rights and Practices. New York: UN.

Leirvag v. Norway. 2004. U.N. GAOR, Hum. Rts. Comm., 58th Sess. U.N. Document. CCPR/C/82/D/1155/2003 (2004). New York: United Nations.

Lena, M. 2017. Update: Malaysian Persecution of Atheists. Available online: http://www.atheistrepublic.com/ blog/lena-m/update-malaysian-persecution-atheists (accessed on 22 November 2018).

Lerner, Natan. 2012. Religion, Secular Beliefs and Human Rights. Leiden: Brill.

Lindkvist, Linde. 2013. The Politics of Article 18: Religious Liberty in the Universal Declaration of Human Rights. Humanity 4: 429-47. [CrossRef]

LoRusso, J. D. 2017. 'Everyone has a faith'. In Stereotyping Religion. Edited by Brad Stoddard and Craig Martin. London: Bloomsbury Academic.

Maddox, Marion. 2005. God Under Howard: The Rise of the Religious Right in Australian Politics. Sydney: Allen \& Unwin.

Malik, Maleiha. 2009. Anti-Muslim prejudice in the West, past and present: An introduction. Patterns of Prejudice 43: 207-12. [CrossRef]

Marshall, Paul, and Nina Shea. 2011. Silenced: How Apostasy and Blasphemy Codes are Choking Freedom Worldwide. Oxford: Oxford University Press.

McKernan, B. 2017. Man 'Sentenced to Death for Atheism' in Saudi Arabia. Available online: https:/www.independent.co.uk/news/world/middle-east/saudi-arabia-man-sentenced-deathatheism-ahmad-al-shamri-hafar-al-batin-appeal-denied-a7703161.html (accessed on 22 November 2018).

Mehta, H. 2017. With \#HangAyazNizami, It's Clear the Anti-Atheist Sentiment in South Asia is Getting Worse. Available online: https://friendlyatheist.patheos.com/2017/03/26/with-hangayaznizami-its-clear-the-antiatheist-sentiment-in-south-asia-is-getting-worse/ (accessed on 22 November 2018).

National Secular Society. 2017. Pakistani Twitter Users Call for Hanging of 'Blasphemer'. Available online: https: //www.secularism.org.uk/news/2017/03/pakistani-twitter-users-call-for-hanging-of-blasphemer (accessed on 22 November 2018).

Nixon, Alan G. 2016. Australia: Conflict, Not Competition. In The Atheist Bus Campaign: Global Manifestations and Responses. Edited by Steven Tomlins and Spencer Bullivant. Leiden: Brill.

Nixon, Alan G. 2018. The Case of Atheist Refugees. Journal for the Academic Study of Religion 31: 2.

Nixon, Alan G. 2019. Public Atheism and 'Islamophobia' on Twitter. In Religion and Belief through the Digital Social. Edited by Alphia Possamai-Inesedy and Alan Nixon. Berlin: DeGruyter.

OHCHR (Office of the High Commissioner of Human Rights). 2019. International Standards on Freedom of Religion or Belief. Available online: https://www.ohchr.org/EN/Issues/FreedomReligion/Pages/Standards. aspx (accessed on 25 May 2019).

Pew Research Center. 2016a. The Factors Driving the Growth of Religious 'Nones' in the U.S. Available online: http://www.pewresearch.org/fact-tank/2016/09/14/the-factors-driving-the-growth-ofreligious-nones-in-the-u-s/ (accessed on 2 April 2018).

Pew Research Center. 2016b. Why America's 'Nones' Left Religion behind. Available online: http://www.pewresearch.org/fact-tank/2016/08/24/why-americas-nones-left-religion-behind/ (accessed on 17 October 2019). 
Pew Research Center. 2016c. Which Countries Still Outlaw Apostasy and Blasphemy? Available online: https:/www.pewresearch.org/fact-tank/2016/07/29/which-countries-still-outlaw-apostasy-andblasphemy/ (accessed on 17 October 2019).

Pew Research Center. 2019. In U.S., Decline of Christianity Continues at Rapid Pace: An update on America's Changing Religious Landscape. Available online: https://www.pewforum.org/2019/10/17/in-u-s-decline-ofchristianity-continues-at-rapid-pace/ (accessed on 17 October 2019).

Siddique, Osama, and Zahra Hayat. 2008. Unholy Speech and Holy Laws: Blasphemy Laws in Pakistan-Controversial Origins, Design Defects, and Free Speech Implications. Minnesota Journal of International Law 17: 303.

Stats NZ. 2019. Losing Our Religion. Available online: https://www.stats.govt.nz/news/losing-our-religion (accessed on 7 October 2019).

Storey, Hugo. 2014. What Constitutes Persecution? Towards a Working Definition. International Journal of Refugee Law 26: 272-85. [CrossRef]

Swan, Lawton K., and Martin Heesacker. 2012. Anti-Atheist Bias in the United States: Testing Two Critical Assumptions. Secularism and Nonreligion 1: 32-42. [CrossRef]

Tulkens, Francoise. 2014. Freedom of Religion under the European Convention on Human Rights: A Precious Asset. BYU Law Review, 509-30. Available online: https://digitalcommons.law.byu.edu/lawreview/vol2014/iss3/3 (accessed on 17 November 2019).

UDHR (Universal Declaration of Human Rights). 1948. G.A. Res. 217A, U.N. GAOR, 3d Sess., 1st plen. mtg. U.N. Document A/810 (Dec 12, 1948). New York: United Nations.

UN (United Nations). 2012. Rep. of the Special Rapporteur on the Promotion and Protection of the Right to Freedom of Opinion and Expression. U.N. Doc. A/67/357, (Sept. 7, 2012). New York: United Nations.

USCIRF. 2018. Annual Report 2018-Tier 2-Malaysia. Washington: United States Commission on International Religious Freedom.

Vienna Convention. 1969. Vienna Convention on the Law of Treaties. United Nations Treaty Series. No. 18232; New York: United Nations, vol. 1155, p. 331.

Wootson, Cleve R., Jr. 2017. A Saudi Man has been Sentenced to Death after Insulting the Prophet Muhammad on Twitter. Available online: https:/www.washingtonpost.com/news/worldviews/wp/2017/04/27/asaudi-arabian-man-has-been-sentenced-to-death-after-insulting-muhammad-on-twitter/?utm_term= $.5 \mathrm{c} 8 \mathrm{fe} 4844 \mathrm{ec} 1$ (accessed on 22 November 2018).

Zuckerman, Phil. 2013. Atheism and Societal Health. In The Oxford Handbook of Atheism. Edited by Stephen Bullivant and Michael Ruse. Oxford: Oxford University Press.

Zúquete, José Pedro. 2008. The European extreme-right and Islam: New directions? Journal of Political Ideologies 13: 321-44. [CrossRef]

Zurairi, A. R. 2017. Targeting Atheists Will Ruin Moderate Image, Malaysia Told. Available online: https: //www.malaymail.com/s/1437259/targeting-atheists-will-ruin-moderate-image-malaysia-told (accessed on 22 November 2018).

(C) 2020 by the author. Licensee MDPI, Basel, Switzerland. This article is an open access article distributed under the terms and conditions of the Creative Commons Attribution (CC BY) license (http://creativecommons.org/licenses/by/4.0/). 
Article

\title{
Complex, Critical and Caring: Young People's Diverse Religious, Spiritual and Non-Religious Worldviews in Australia and Canada
}

\author{
Anna Halafoff ${ }^{1, *}{ }^{-}$, Heather Shipley ${ }^{2}$, Pamela D. Young ${ }^{3}$, Andrew Singleton ${ }^{4}(\mathbb{D}$, \\ Mary Lou Rasmussen ${ }^{5}\left(\mathbb{D}\right.$ and Gary Bouma ${ }^{6}(\mathbb{C})$ \\ 1 School of Humanities and Social Sciences, Deakin University, Melbourne, VIC 3125, Australia \\ 2 Department of Classics and Religious Studies, University of Ottawa, Ottawa, ON K1N 6N5, Canada; \\ hshipley@uottawa.ca \\ 3 School of Religion, Queens's University, Kingston, ON K7L 3N6, Canada; youngpd@queensu.ca \\ 4 School of Humanities and Social Sciences, Deakin University, Geelong, VIC 3125, Australia; \\ andrew.singleton@deakin.edu.au \\ 5 School of Sociology, Australian National University, Canberra, ACT 0200, Australia; \\ MaryLou.Rasmussen@anu.edu.au \\ 6 School of Social Sciences, Monash University, Melbourne, VIC 3800, Australia; Gary.Bouma@monash.edu \\ * Correspondence: anna.halafoff@deakin.edu.au
}

Received: 12 February 2020; Accepted: 30 March 2020; Published: 3 April 2020

\begin{abstract}
Recent scholarly and media perspectives on religion and youth have often depicted young people as being apathetic when it comes to religion. The methods used in research on religion are also typically informed by outdated, fixed idea of religious identity that are no longer applicable, especially to young people. This paper confronts these issues by applying contemporary theories of religious diversity, including lived religion and religious complexity, to the findings of the Canadian Religion, Gender and Sexuality among Youth in Canada (RGSY) study, the Australian Interaction multifaith youth movement project, and the Worldviews of Australian Generation Z (AGZ) study. These three studies revealed that young people negotiate their worldview identities in complex, critical and caring ways that are far from ambivalent, and that are characterised by hybridity and questioning. We thereby recommend that policies and curricula pertaining to young people's and societies' wellbeing better reflect young people's actual lived experiences of diversity.
\end{abstract}

Keywords: religion; diversity; young people; spirituality; non-religion; complexity; hybridity

\section{Introduction}

Dominant thinking on religion and youth assumes that young people are largely apathetic about religion (Carlson 2012; Lucas 2008; Lunau 2009; Ron 2010), and contemporary research on religion often uses outdated, fixed frameworks of religious identity to determine its methods. As a result, people's and notably young people's, lived and fluid experiences of negotiating religious, spiritual and non-religious diversity are frequently inadequately described (Halafoff and Gobey 2018; McGuire 2008; Shipley 2018; Young 2018). Three co-authors of this paper, Anna Halafoff, Heather Shipley and Pamela D. Young first raised these concerns, which emerged from their respective and then yet-to-be-published research findings in Australia and Canada, at a workshop on 'Religion, Youth and Identity' held at the University of Ottawa as part of the Religion and Diversity Project in $2014 .{ }^{1}$

1 These workshop papers were published in 2018 in Youth, Religion and Identity in a Globalizing Context, eds. Paul L. Gareau, Spencer Culham Bullivant and Peter Beyer. Leiden: Brill—see References for details. 
This paper addresses these issues by discussing the findings of Halafoff's Interaction study, Young's and Shipley's Religion, Gender and Sexuality among Youth in Canada (RGSY) study, and Singleton's, Rasmussen's, Halafoff's and Bouma's Worldviews of Australian Generation Z (AGZ) study. The latter study was in part informed by the prior two studies' findings. All three research projects revealed three main themes, in contrast to dominant opinions on religion and youth: that young Australians and Canadians display a far from 'whatever'/ambivalent attitude toward religion, and that their worldviews are characterised by hybridity and questioning. We also argue in this paper that young Australians and Canadians negotiate their worldview identities in complex, critical and caring ways.

This aligns with contemporary theories of religious diversity, including Meredith McGuire's Lived Religion (2008), Nancy Ammerman's Everyday Religion (2007), Linda Woodhead's 'New Style Religion' (2012) and Inger Furseth's application of complexity theory (2018a, 2018b) to the study of religious diversity. These theories have arisen from research that was mainly focused on adults in the USA, UK, and the Nordic countries, which will be explored in more detail below. Moreover, as Steven Vertovec (2007) noted over a decade ago, public policy, understanding and research still does not adequately reflect the complex, lived superdiverse realities of peoples', and in this case, young people's lives. We thereby also recommend that young people's worldviews be considered more seriously among stakeholders responsible for policies, and also curricula pertaining to diversity and wellbeing, to better match these young people's actual lived experiences.

\section{Methods}

As stated above, this paper reports data from three studies of the worldviews and religious identities of Australian and Canadian Youth—the Interaction study, the Religion, Gender and Sexuality among Youth in Canada (RGSY) study, and The Worldviews of Australian Generation Z (AGZ) study. The InterAction study, conducted in 2013-2014, comprised 11 interviews with religious and non-religious young persons, aged between 20-31, who were all engaged in the Australian interfaith youth movement Interaction (Halafoff and Gobey 2018). The Religion, Gender and Sexuality among Youth in Canada (RGSY) study, conducted in 2012-2014, surveyed 486, 18-25-year-old participants from a wide variety of religious and nonreligious backgrounds (Young and Shipley 2020). The Worldviews of Australian Generation Z (AGZ) study, conducted in 2016-2018 focused on religion, sexuality and young people. The AGZ study comprised three stages: 11 focus groups with a total of 94 students in Years 9 and 10 (ages 15-16); a nationally representative random-digit-dial (RDD) telephone survey of 1200 people aged 13-18; and 30 in-depth, follow-up interviews with survey participants (Singleton et al. 2019). The findings of these studies are presented thematically below, as they relate to contemporary theories of religious diversity outlined in the next section.

\section{Risks and Religious Complexity}

The events of 11 September 2001 and the 2005 London bombings catapulted religion into the public mind and resulted in a securitisation of religion. Fears of homegrown terrorism resulted in young people being seen as at risk of radicalisation, and consequently as risks to broader society (Lentini et al. 2009; Mansouri and Halafoff 2014). Following these events, scholars in the US such as Ammerman (2007) and McGuire (2008) chose, by contrast, to highlight 'lived' and 'everyday' aspects of religion and spirituality. This research uncovered the fact that dominant frameworks and methods for understanding religion and spirituality in contemporary societies were inadequate and needed to better reflect people's actual experiences.

McGuire (2008) observed how complex and diverse the contemporary religious lives of adults in the USA are. Rather than subscribing to the beliefs, norms and practices of a single religious organisation, she instead found that an individual's religious experiences are 'ever-changing, multifaceted ... messy-even contradictory' (McGuire 2008, p. 4). People blend "traditional" religious practices with newer religious and/or spiritual expressions, and the boundaries between these are often blurry. She 
also found that 'people construct their religious worlds together', through shared experiences and meanings, so they are relational and social (McGuire 2008, p. 12). People can also be critical of religion, including their own religious leaders, and at the same time be inspired by their religious teachers and teachings to stand up against injustices. Consequently, McGuire called for scholars to examine 'everyday religion as lived' with a focus on embodied practices, experiences and expressions (McGuire 2008, p. 1).

Ammerman (2013) also problematised the binary where typically, religion is thought to be organised, communal, and declining, while spirituality is viewed as more individual, innovative and increasing in popularity. Instead she found, in her research based on adults in the US, that religion and spirituality actually shared many common characteristics, such as believing in God or a divine power, participating in shared practices, and following ethical frameworks. She also stressed that people could be spiritual and religious concurrently (Ammerman 2013).

When summarising the findings of her Religion and Society Programme in the UK, which involved studies of adults and young people, Woodhead (2012) similarly argued that while 'old style religion' centred on identification with one religious tradition and abiding by its rules, combined with regular attendance and participation in local religious practices, 'new style religion' is characterised by individual choice, fluidity, and hybridity. She also noted that the new style hasn't simply replaced the old, but that rather 'everything [is] going on at once', with both old- and new style religion existing alongside a rise of spirituality and the non-religious, and at times overlapping with one another.

More recently, Furseth (2018a, 2018b), in her research on the changing demographics and public role of religion in the five Nordic countries, relatedly argued that 'religious complexity' best describes contemporary religion, with 'seemingly contradictory trends,' of 'religious decline, growth, and change' happening concurrently (Furseth 2018a, p. 16). These include a decline in individual religiosity, a growth in religious diversity, an increasing interest in alternative spirituality and 'public visibility of religion', but also a continuity of religion's presence in the public sphere (Furseth 2018b, pp. 292-93).

It follows that contemporary expressions of worldviews-be they religious, spiritual and/or non-religious-in the USA, UK and in Nordic societies, can be categorised as complex, changeable and hybrid, and that these worldviews also often inform people's ethical positions and actions. While most of the above research has focused on adults, our data on young Australians and Canadians certainly also support these assertions and provide additional details about how young adults negotiate their intersecting and fluid worldviews.

Generations $\mathrm{Y}$ and $\mathrm{Z}$ have been raised in a time where religion has been more prominent in the media and public life following the events of 11 September 2001. Concurrently, there has been a dramatic rise in people declaring themselves to have 'no religion', particularly in Western societies such as Australia and Canada, and a robust critique of religion in the public sphere. A total of $29 \%$ of Canadians and 30\% of Australians describe themselves as religiously unaffiliated (Lipka 2019; ABS 2017). Our research has found that there is a growing trend among young people to identify as non-religious, or spiritual but not religious, at the same time as some of them remain religiously committed. Young people also live, study and work in increasingly superdiverse societies, in terms of not only religion and culture, but also gender and sexuality. As a result, they have been exposed through the media to public debates pertaining to various diversities and contestations between them, such as in marriage equality debates and through the \#Metoo movement. At the same time, both Australia and Canada provide very little education about religious, gender and sexuality diversity in state schools, and these are also 'hot' and controversial topics (Rasmussen 2006; Bouma and Halafoff 2017; Singleton et al. 2019; Young and Shipley 2020). All three studies—Interaction, RGSY and AGZ-have examined these issues to some degree.

We now turn to three main themes that emerged from the three studies' findings on young Australians and Canadians worldviews, namely, a lack of ambivalence/'whatever' attitudes, and growing hybridity, and questioning pertaining to religion among this cohort. We also examine how 
these young people negotiate their worldview identities in complex, critical and caring ways. These assertions are explored in more detail below.

\section{Whatever?}

Previous analyses of religion and youth in Australia have focused on how secularism, individualism and consumerism have led to a decline in religious affiliation, and a general lack of interest in, and ignorance about, religion among Australian youth. They have presented young people's engagement with religion and spirituality as being largely trend-based and somewhat shallow, and strongly influenced by social media and popular culture (Halafoff and Gobey 2018; Lucas 2008; Possamai 2009).

By contrast, Halafoff and Gobey (2018) in their Interaction study provide a signpost to the importance of religion in the lives of young people who are committed to interfaith activism, evident in their career and lifestyle choices. These young Australians, including Buddhist, Christian, Hindu, Muslim and Atheist participants, certainly did not hold a 'whatever' (Lucas 2008), ambivalent or indifferent view of, or approach toward, religion. Far from it, they took religion seriously, and were deeply engaged in religious thought and practices, and/or in critiquing religion from a young age. As this study only included 11 interviewees active in an interfaith movement, it's findings certainly weren't representative of all Australian youth, but were nonetheless interesting as they challenged previous assumptions regarding the religious indifference believed to characterise the entirety of Gen Y.

Shipley (2018, p. 191) also noted how young people's religious identities are often 'essentialised' and 'frequently represented' and 'misunderstood as apathy' (Carlson 2012; Lunau 2009; Ron 2010). The RGSY study instead found that young Canadians had 'articulate passionate, engaged and dynamic religious identities' (Shipley 2018, p. 192). Participants in the Canadian study were deeply concerned about justice, values and making the world a better place, whether or not they explicitly articulated these goals as religious. Participants also worked hard to negotiate their (non)religious lives in relation to their other cultural and social values (Young and Shipley 2020).

The AGZ findings clearly establish the dynamism that characterises young people's religious affiliations. The AGZ study used latent class analysis of the teens' worldviews to identify six statistically distinct types: $23 \%$ 'this-worldly'/non-religious, 15\% indifferent, $18 \%$ spiritual but not religious, $8 \%$ religious and spiritual, 20\% nominally religious and 17\% religiously committed (Singleton et al. 2019). ${ }^{2}$ These are significant findings, as they document the complexity of worldviews held by AGZ teens. The AGZ study highlights the differences among those who are non-religious as being either 'this-worldly', 'indifferent', or 'spiritual but not religious'. At the same time, the substantial presence of the religious types, the 'religiously committed', 'nominally religious' and 'religious and spiritual', of young people further complicate the picture in this study.

As the vast majority of AGZ teens chose to identify as 'this-worldly', 'spiritual but not religious', 'religious and spiritual' and 'religiously committed', with only a minority of $15 \%$ who are religiously indifferent/'whatever' and 20\% who are nominally religious. It follows that their non-religious, religious and/or spiritual worldviews are important to most AGZ teens. To illustrate, one AGZ interviewee was born into a Buddhist family but this wasn't particularly central to her until as a teenager she became involved in regular charity work, by volunteering to fundraise for natural disaster aid, conducted by her local Buddhist temple. She described this as a 'life-changing' experience. She now attends the temple regularly and lights incense and prays each night at her family's home altar with her mother.

This section has highlighted how, while a significant proportion of young Australians and Canadians are religiously indifferent, they are a minority, and ambivalence certainly does not categorise the entire cohort. Instead, their religious, non-religious and spiritual identities are complex, similar to what Furseth (2018a, 2018b) has observed. They haven't replaced old style with new style religion, and aren't all turning away from religion either (Woodhead 2012). Religion, being this-worldly and/or

2 Percentages may not add up to 100 due to rounding 
spirituality, are all things they identify with, and that many of them care about and take seriously. This also, at times, inspires them to be caring toward others, as McGuire (2008) also noted. It is indeed, as Woodhead (2012) exclaimed, all going on simultaneously!

\section{Hybridity}

Another theme that emerged across the three studies was hybridity when it came to young Australian and Canadian's diverse worldviews. This hybridity and complexity, as scholars have previously noted (McGuire 2008; Halafoff and Gobey 2018; Shipley 2018), needs to be considered in terms of the methods used to ascertain people's worldviews. Asking people to simply tick one box on a census form or specify a religious or non-religious identification is no longer an adequate measure of what young people believe, or of what institutions they embrace or reject. This has implications for law, policy and curricula that focus on religion and belief, as a single, old-style category of practice and belonging. Asking questions linked to religiosity only tends to overstate the significance of dominant religions and to obfuscate young people's other worldviews, both religious and non-religious. The Interaction and RGSY studies revealed these limitations and hybridity as a significant trait among this cohort. The AGZ study's design, informed by the Interaction and RGSY's findings, set out not to simply offer limited, fixed categories for participants to choose from. It provided opportunities for AGZ teens to identify not only as non-religious, religious and/or spiritual, as described above, but as having more than one religious identification. It also presented a wide range of choices pertaining to sexual identity, allowing for more complex and hybrid identifications. ${ }^{3}$

The Interaction study found that hybridity was a central characteristic of young Australians' religious identities. This was largely as a result of processes of globalisation and their, and their parents' off and online mobility. This included conversion from Christianity to Tibetan Buddhism, and from Judaism to Eckankar ${ }^{4}$ among their parents, and interests in and identification with spirituality and religion, or spirituality and non-religious worldviews (Halafoff and Gobey 2018).

In the RGSY study, Shipley (2018, p. 193) also identified hybridity as a characteristic of this cohort, whose religious, non-religious and/or spiritual identities were 'varied and complex' (Shipley 2018, p. 19). In the final RGSY English survey, respondents identified as follows: Buddhism $1.9 \%$, Christianity $61 \%$, Hinduism $0.9 \%$, Islam $4.3 \%$, Judaism $3.3 \%$, Sikhism $0.2 \%$. as non-religious $20.3 \%$, spiritual but not religious $14.2 \%$ and other $9.2 \%$ (includes theist, agnostic, Wiccan, combination of religions, etc.). The RGSY study also revealed a substantial hybridity among the sample of Christian participants who also engaged with and practiced other traditions such as Wicca, Buddhism, and other spiritual practices (Shipley 2018, p. 194). Respondents described how they were exposed 'to multiple types of religiosities and practices at home, in school, in religious organisations, and online' (Shipley 2018, p. 197) and how they often engaged in a variety of diverse religious practices. Many participants were not content to claim one (non) religious identity. The often claimed several (Young and Shipley 2020).

The AGZ study set out to further investigate religious and/or non-religious hybridity, and by doing so it revealed two main types of hybridity among Australian teens. Firstly, it provided respondents with the capacity to select more than one religious identity in the survey. Eight per cent of participants who identified as religious identified with more than one religious tradition (approximately $3 \%$ of all teens), and this was largely as a result of having parents from different religious traditions. Participants were asked to identify with only one religion or non-religion first, so that the AGZ data could be compared with previous studies that only allowed for one religious identification. Once they had done so the AGZ participants were then given the opportunity to also identify with other traditions.

3 A detailed elucidation of the methods employed in the AGZ study is contained in Rasmussen, M., Graefenstein, S., Singleton, A., Halafoff, A., and Bouma, G. (forthcoming). 'Methodological Challenges of designing a Survey to capture young people's (non-binary) affiliations in relationship to religion, sexuality and gender,' International Journal of Social Research Methodology.

4 Eckankar is a new religious movement, founded in 1965. 
Of the Christians, 17 teens identified with more than one Christian tradition, seven identified with Christianity and Buddhism, six identified with Christianity and an other religion, two identified with Christianity and Islam. Of the Buddhists, two identified as Christian also, and one identified as another religion as well. Of the Hindus, one identified as Christian also, and one identified as Sikh as well. Of the Muslims, one identified as Christian also. Of the Jews, one identified as Christian as well. While this is a small sample of the 1200 participants in the AGZ survey, it is nonetheless still a significant finding.

In the AGZ focus groups, students noted both the benefits and challenges of growing up in families with two religious traditions. One student favourably described their Jewish-Christian family and how they celebrated both customs: ‘ ... some people are, like half Jewish, half Christian or, like, have a bit of Christian. So, like ... I celebrate Christmas and stuff. So I feel like-there-like a lot of us are Jewish but then also have other cultures that they celebrate with their families.' Another student, by contrast, noted the tensions of being raised in a dual religious family and negotiating their hybrid religious identity. They said, '[m]um's side is Catholic and my Dad's side is Buddhist... And it's kind of contradicting.'

The second, and more prevalent, form of hybridity in the AGZ sample was that of being spiritual and religious, or spiritual and [but] not religious. While $35 \%$ of respondents said they were neither religious or spiritual, and $12 \%$ were 'religious but not spiritual', $22 \%$ said they were 'spiritual but not religious', and 16\% were 'religious and spiritual'. Fourteen percent could not choose from those categories. In terms of the AGZ teens' spiritual alternative practices and beliefs, $20 \%$ believed in astrology, 30\% in reincarnation, 50\% in karma and 22\% had practised yoga and 30\% had practised meditation (outside of school) (Singleton et al. 2019).

For example, when pondering her relationship to spirituality and religion, one AGZ interviewee said, 'I would say I am, um, spiritual I guess'. She explained, to her, that being spiritual meant that 'you believe there is like a higher order out there somewhere.' She described how she is 'a firm believer in like karma and like if you do good things in the world you will receive good things' which she acknowledged came 'definitely from the Buddhist side' of her family, given that her parents were Buddhist and she had been raised 'sort of Buddhist'. However, she also said she was 'agnostic' about rebirth/reincarnation. Despite not identifying as, or necessarily being, religious, this interviewee was aware of the influence that elements of both Buddhism, from her parents, and Catholicism, and Catholic values from her Catholic schooling, had had in shaping her spiritual identity and beliefs.

Another AGZ interviewee described how she was vegan, concerned about animal rights and had some interest in crystals and meditation. Her main spiritual practice was Tarot cards and she explained how, 'tarot cards are something if I don't know what to do in a certain situation, I would use them and then try and like get some clarity. And I think that's probably what people do with religion too.' This interviewee was introduced to various spiritual and religious practices and beliefs by her father, who had been religiously experimental throughout his life (as many parents of the AGZ interviewees were). As she describes it: 'he was really into Christianity at one point and then he was really into Buddhism and stuff like that.' While she didn't describe herself as religious, she spoke about her attraction to all religions. In addition to her father's influence, her understanding of her own religious and spiritual life was significantly shaped by her Studies of Religion course in her final years of schooling. It was through the course that she ultimately came to think of herself as 'new-age kind of religious'.

These findings reveal that similarly to what McGuire (2008), Ammerman (2013) and Woodhead (2012) have argued, hybridity and complexity are factors in these young Australian and Canadian's religious, non-religious and/or spiritual identities, and that these findings should inform research methods, and questions, as well as policy and curricula related to religion, spirituality and young people.

\section{Questioning}

Questioning of religion among young people, pertaining to their identity but also, more broadly, religion in society, was another major finding of the Interaction study. While most participants' religious 
identities were more influenced by their parents than other factors, such as their peers, school or popular culture, many of them were adhering to their parent's religious traditions and questioning them concurrently. They certainly frequented websites and blogs, but not in a superficial or consumerist manner. Rather, they searched the internet with intention, to answer their genuine questions about religion and life's meaning. Their attitude to religion was critical and deeply considered. They were broadly accepting of religious diversity, curious about religions, and wanted to know more about them. Once again, they certainly cared about these issues (Halafoff and Gobey 2018). For example, one of the Interaction Christian interviewees stated:

I'm struggling with that a little bit at the moment and I think I would more call myself spiritual rather than ... it's sort of tough. I think it's an age thing ... I'm not really sure whether Christianity as such and Anglicanism ... is really where I'm at entirely so ...

Another Interaction respondent explained how he became an atheist, both through questioning religious belief and through researching religion on the internet:

It was through, for me an experience when I was 17 years old. I went on student exchange and I was situated in ... the Bible Belt in the United States. And so staying in America and living with a family that was very religious and all of my high school friends were very Evangelical Christian believers. That sort of forced me to make up mind about what I believed in and you know the questions were 'is there a God, is the Bible the word of God, was Jesus the son of God, is evolution true,' all of these questions all of a sudden were very important to me ... arriving at my own conclusion, I guess that science was the best tool to figure out the reality of the world.... I did a lot of reading online and I read a lot of books ... There were a lot of Atheist sort of blogs. And ... it was just something I was really passionate about ...

Shipley (2018, p. 193) also identified hybridity and 'questioning' as characteristics of the RGSY cohort. For example, one 24-year-old spiritual but not religious Canadian respondent, who had been raised Catholic, stated:

Right now, I'd say I'm at a confused stage, to say the least. I'm-I'm very interested in different aspects of different religions... I've also been in contact with quite a lot of Indigenous traditions ... and that has also been quite influencing [sic] ... I haven't, you know, given up believing altogether, but I'm also very confused and can't really identify where I stand.

Shipley (2018, p. 197) has highlighted that questioning of and complicated attitudes about religion often arose in young people as a result of conflicting views that some religions had pertaining to gender identity and sexuality equality. For example, one of the RGSY respondent's religious identity has been 'complicated $\ldots$ by living in a common-law relationship with a transgender (female to male) partner'. In the respondent's conservative Catholic community, being transgender is unacceptable, and so this created 'a barrier in her personal self-identification as religious' and made her question religion more generally.

Another respondent specified her religious identity as 'questioning', given she was 'working through her personal disagreements with Catholic teachings (such as sex outside marriage, treatment of the lgbtqi community, and women's ordination)'. At the same time, she said that 'she feels strongly that she wants to raise her children within the Catholic tradition and get married in a Catholic Church ... wanting similar experiences and the community that it has offered to her' (Shipley 2018, pp. 197-98). Another respondent was raised in a Catholic household, but didn't experience a 'personal connection' with the Catholic teachings she received at home and in church. She questioned her religious identity and converted to Islam. At the time of her interview, she was engaging in both personal and online Islamic practices, as she could no longer attend her local mosque given what she described as its 'sexist, racist and homophobic' attitudes. She hoped to find a more progressive and inclusive mosque in future (Shipley 2018, p. 198).

It is important to note that participants in all three of these studies, while critically aware of religion's capacity to impinge at times upon the rights of others, were not entirely negative about religion. In the RGSY study, they also highlighted positive aspects of religion, such as its capacity to 
provide community and good values, such as respect for others, as things they valued (Shipley 2018, p. 200; Young and Shipley 2020).

This type of questioning regarding religion during teen years was also evident in the AGZ study. For example, one of the AGZ study interviewees, who has a parent who is a committed member of the Church of Latter-day Saints, described how, when she was a teenager, she went through an important time of personal questioning, to be sure that her religion was right for her and that she wasn't simply following convention. She explained how:

I was really young, like, from a baby on I've been part of that religion and then there was a point in time where I was like, when you're a teenager and you're thinking, there are so many options for me, what's going on, is this real, is this right, is this true, and it-it really did hit me and I was like, what am I doing? ... I didn't want to just go into life and be like yeah, this is the religion that I'm in and just like a follower. It was more like I wanted to make my choice and to see for myself if it was making me happy, and me 'me'.

Alongside this questioning, and similarly to the RGSY study, the vast majority of AGZ teens have a positive view of religious diversity and religious freedom. However, these positive views were often moderated when participants perceived conflicts between religious practice and the rights of others. While $93 \%$ of participants agree with the statement: 'Having people of many different faiths makes Australia a better place to live', AGZ teens' opinions were far more divided on issues where religion may have the capacity to impinge on their rights or to offend people. Half of Australia's teens (50\%) thought that people with very strong religious beliefs are often too intolerant of others and $45 \%$ thought that religion causes more problems than it solves (Singleton et al. 2019). These results display a critical awareness and strong questioning of religions' place in society, particularly in negotiation with other freedoms and rights. Students in one of the AGZ focus groups stated a variety of orientations toward questioning:

P1: ... I think a big thing about it is ... how we view religion can be in a sense altered by ... to an extent some people believe that [their] religion has to be the right one ...

P2: I've only really disagreed with people about things, such as like I guess you could kind of call it political view or something or people who are like homophobic or something...

P3: Well, I only have an issue with it if-I don't generally care what-what a person believes, as long as they don't try and implement the way they think on the way I think.

P2: Yeah, or-or as long as they are not, um, making specific reference or offending people with like their views.

In this exchange, we see participants concerned about religious people asserting that their faith is the "right one". Political views and homophobia are deemed ripe for contestation, especially if they are seen as offensive or imposing on individual beliefs. One of the spiritual but not religious AGZ interviewees echoed these sentiments when he described how his circle of friends had a 'variety of beliefs and religions', and that they 'all got along fine'. He added, 'the main thing was, I don't mind whatever you identify as, as long as you don't try and force your beliefs upon me.' Another nominally Hindu AGZ interviewee explained how:

I've noticed that it -it does kind of affect more when people push religion and their values. Like, I'm happy to know about it and respect theirs, but ... it kind of bothered me ... I think as long as people respect everyone's, um, kind of boundaries and their own beliefs, it's-it's justified to, um, be religious I guess.

In the excerpts above, AGZ participants repeatedly questioned beliefs that impacted upon the views and rights of others, but this discomfort with infringement is somewhat qualified ('kind of', 'I only have an issue if'). One senses that participants are inclined to live and let live, except when people are perceived to cross boundaries by imposing their beliefs on others, or if they're being explicitly 
intolerant. Potentially, this tendency towards qualification was a function of the methodology utilised in the study. Speaking with young people in focus groups meant they had to enunciate different types of worldviews in front of peers, a vulnerable move at any age. Qualification may provide focus group participants with an opportunity to voice opinions without appearing too strident themselves.

Similarly to the RGSY study findings, clashes between religious freedom and sexuality rights appeared to be a highly charged issue for participants. The AGZ survey was, coincidentally, conducted at the same time as Australia's non-compulsory postal vote on same sex marriage. AGZ teens, who were excluded from voting on the question of marriage equality, were highly supportive of sexuality diversity. Eighty-two percent of teens supported marriage equality, compared to the $62 \%$ of adults who voted for it in the Marriage Equality survey (Singleton et al. 2019).

Some students who participated in the AGZ focus groups were highly aware of internal tensions between progressive and conservative movements within religions. Moreover, in the post-survey interviews, when asked about religious exemptions to hire/fire staff in religious organisations, including schools, most AGZ teens were surprised that these exemptions even existed and were strongly opposed to them, especially when lesbian, gay, bisexual, trans and queer (LGBTQ) staff or students could be discriminated against on the basis of their gender or sexuality. This once again displays a strong critique of religion and a deep level of care about how LGBTQ people can be impacted by discrimination related to religious freedom.

In the surveys and interviews a direct relationship between religiosity and LGBTQ rights was also noted. Strongly held religious beliefs, among the 'religiously committed', were the most powerful indicator that a participant would be against LGBTQ rights and freedoms. This also portrays a level of critique of progressive pro-LGBTQ views and a strong sense of investment in these issues, although it also arguably depicts a lack of empathy regarding the negative impacts of prejudice against LGBTQ individuals and communities.

One religious and spiritual AGZ interviewee queried 'so they can still do that?', with regard to religious exemptions against LGBTIQ pupils and teachers. One religiously committed Buddhist said it was 'ridiculous' and a this-worldly non-religious teen simply incredulously said 'wow'. A this-worldly AGZ teen said: 'I just don't agree with that at all ... Just I think having to fire someone because-or like exclude a certain student or teacher from just being themselves, I think is just outrageous.' Finally, another AGZ this-worldly interviewee explained the hypocrisy of the conservative religious position in the religious freedom debate, which fights for the right to discriminate against others in the name of freedom, but only for their religious group at the expense of the rights of others:

I'm not particularly aligned with the concept of religious freedom. I figure if they're the set of rules, it doesn't really matter what you practice, you have to follow those rules. Like, also if, there's a lot of white Australians trying to fight the people wearing burqas, to take them off ... And they're quite opposed to having LGBT classes in the school, which is kind of along the same lines, when you think about it. So, religious freedom, but only for us.

Young Australian's and Canadians are often questioning their own religious, spiritual and/or non-religious identities, and these are fluid, and changing over time, similar to characteristics McGuire (2008) and Woodhead (2012) have observed regarding contemporary religious identity and participation. In addition, young Australian's and Canadians were most likely to question religious freedom when it impacts on others' rights, particularly rights pertaining to sexual and gender diversity and equality. This demonstrates their capacity for critical reflexivity and a sense of care pertaining to these issues, and particularly for LGBTQ persons, who may be subject to negative judgements and discrimination and impacted by state-sanctioned religious exemptions. Strongly religious young people, with anti-LGBTQ views, also provide evidence of questioning the dominant social norms of their peers, who largely favor LGBTQ equality. In all of the above cases, these are indubitably issues that young people take seriously. 


\section{Conclusions}

This paper has explored how all three research projects, the Interaction, RGSY and the AGZ studies, revealed three main themes that young Australians and Canadians have a far from 'whatever'/ambivalent attitude toward religion, and that their worldviews are characterised by hybridity and questioning. We also revealed that young Australians and Canadians negotiate their worldview identities in complex, critical and caring ways.

Halafoff and Gobey (2018) found that the Interaction participants questioning did affirm narratives of individualism, as they were 'reflexively constructing, reevaluating, and reconstructing their own religious, spiritual and non-religious identities'. Concurrently, they noted that these young people's choices weren't simply made individually, as they were highly influenced by socialising agents such as their parents, peers, schools, and media. They thereby concluded that these young Australians religious, spiritual and/or non-religious identities were 'fluid, changing, and in many cases contain[ed] significant reflexive pauses' and that 'hybridity, mobility, commitment, questioning, and interconnectivity' characterised these young people's religious identity formation and interfaith youth engagement.

Shipley (2018, p. 200) also emphasised that the 'RGSY respondents are carefully negotiating these multiple aspects and possibilities' of being religious, spiritual, non-religious and/or questioning'. She added:

Being self-identified as questioning, spiritual but not religious (SBNR), or religious does not define in strict terms their identities or place them in neat boxes ... And the limited language could be a factor in widespread assumptions regarding youth's disinterest or apathy toward religion, beliefs and spirituality ... The language of religiosity is evolving and ... youth studies regarding religious identity lay bare the linguistic restrictions.

Shipley (2018, p. 205) also concluded that 'the evolving nature of belief, faith, identity and practice' of the RGSY religious and non-religious respondents, is 'thoughtful and considered', and influences the 'clear choices' they are making in 'their notions about social justice, kindness, compassion, and honesty'. Issues of sexuality equality, in particular, have had a profound impact on how they engage or chose not to engage with conservative religions.

The AGZ study's six worldview types provide further empirically robust evidence of religious complexity in Australian society, and evidence that only a minority, 15\%, of AGZ teens are indifferent regarding religion and spirituality, and only $20 \%$ are nominally religious. This-worldly AGZ teens have strong opinions about religion and chose not to be identified as religious - this is a considered position. Similarly, spiritual but not religious teens have decided not to identify as religious, but rather as spiritual, and are engaged in a variety of spiritual practices and hold spiritual worldviews. Religion certainly plays an important role in the religiously committed teens' lives. Moreover, the AGZ focus group and interviewee data are rich with examples of religious hybridity and critical reflexivity when it comes to identity and debates on religious freedom, and the impact this may have on the rights of others and especially of LGBTQ persons. Whether they respected sexual diversity or not, AGZ teens really cared about these issues and, for the most part, thought that religious rights should not triumph over the rights of others.

The findings of these three studies on young Australians' and Canadians' worldviews, and particularly the three themes of a lack of ambivalence/'whatever' attitudes, hybridity, and questioning, as well as the three complex, critical and caring ways in which they negotiate their worldview and identities, align with McGuire (2008), Ammerman (2013), Woodhead (2012) and Furseth's (2018a, 2018b) studies. They also highlight the need for a greater awareness of the complexity of young people's lived realities when it comes to religion, spirituality and non-religion. This is of great significance when it comes to education, health and wellbeing policies, curricula and practices for young people, which are still often informed by outdated and limited understandings or biases when it comes to religion. Our findings may also inform other scholar's research on religion and young people in diverse contexts, and research on religion in contemporary society more broadly. 
Finally, young Australian and Canadian's exposure to public debates involving religious freedom and other rights - notably sexuality rights - and their cognizance and criticisms of religions' capacity to impinge upon the rights of others, is having a profound effect on shaping young people's identities and worldviews. This may indeed be a significant factor related to future decline in religious affiliation. The opinions of young people must be considered in these debates, as the majority of them will not abide with religious rights being able to triumph over and above the rights of others, and certainly not when it comes to sexuality rights. Consequently, we argue that current policy and legal debates on LGBTQ rights, religious freedom, and religious exemptions, heed the complex, critical and caring voices of young people.

Author Contributions: Conceptualization, A.H., H.S., P.D.Y., A.S., M.L.R., G.B.; formal analysis, A.H., H.S., P.D.Y., A.S., M.L.R., G.B.; writing—original draft, A.H., H.S., P.D.Y., A.S., M.L.R., G.B.; writing-review and editing, A.H., H.S., P.D.Y., A.S., M.L.R., G.B.; All authors have read and agreed to the published version of the manuscript.

Funding: The Interaction study was supported by Deakin University's Central Research Grants Scheme; The RGSY research was supported by the Religion and Diversity Project (Social Sciences and Humanities Research Council of Canada Major Collaborative Research Initiative, led by Lori G. Beaman); The AGZ research was supported by the Australian Research Council, ARC Discovery Project: DP160102367.

Conflicts of Interest: The authors declare no conflict of interest.

\section{References}

ABS. 2017. 1266.0-Australian Standard Classification of Religious Groups. Canberra: Australian Bureau of Statistics. Ammerman, Nancy T., ed. 2007. Everyday Religion: Observing Modern Religious Lives. Oxford: Oxford University Press.

Ammerman, Nancy T. 2013. Spiritual but Not Religious? Beyond Binary Choices in the Study of Religion. Journal for the Scientific Study of Religion 52: 258-78. [CrossRef]

Bouma, Gary D., and Anna Halafoff. 2017. Australia's Changing Religious Profile-Rising Nones and Pentecostals, Declining British Protestants in Superdiversity: Views from the 2016 Census. Journal for the Academic Study of Religion 30: 129-43. [CrossRef]

Carlson, Kathryn Blaze. 2012. Organized Religion on the Decline: Growing Number of Canadians 'Spiritual But Not Religious'. National Post, December 21.

Furseth, Inger. 2018a. Introduction. In Religious Complexity in the Public Sphere: Comparing Nordic Countries. Edited by Inger Furseth. Cham: Palgrave, pp. 1-29.

Furseth, Inger. 2018b. Secularization, Deprivatization, or Religious Complexity. In Religious Complexity in the Public Sphere: Comparing Nordic Countries. Edited by Inger Furseth. Cham: Palgrave, pp. 291-312.

Halafoff, Anna, and Laura Gobey. 2018. 'Whatever': Religion, Youth, and Identity in 21st Century Australia. In Youth, Religion and Identity in a Globalising Context. Edited by Paul L. Gareau, Spencer Culham Bullivant and Peter Beyer. Brill: Leiden, pp. 255-78.

Lentini, Pete, Anna Halafoff, and Ela Ogru. 2009. Perceptions of Multiculturalism and Security in Victoria: Report to the Department of Premier and Cabinet, State Government of Victoria. Melbourne: Monash University.

Lipka, Michael. 2019. 5 Facts about Religion in Canada. FACTTANK, Pew Research Centre. July 1. Available online: https://www.pewresearch.org/fact-tank/2019/07/01/5-facts-about-religion-in-canada/ (accessed on 15 March 2020).

Lucas, Ben C. 2008. (Director) 2008. Y God. Available online: https://www.imdb.com/title/tt1730575/ (accessed on 20 March 2020).

Lunau, Kate. 2009. Youth Survey: Teens lose faith in droves, Islam and atheism are on the rise while Christianity fades. Maclean's, April 7.

Mansouri, Fethi, and Anna Halafoff. 2014. Introduction: migrant youth, intercultural relations and the challenges of social inclusion. Journal of Social Inclusion 2: 1-4. [CrossRef]

McGuire, Meredith. 2008. Lived Religion: Faith and Practice in Everyday Life. New York: Oxford University Press.

Possamai, Adam. 2009. Sociology of Religion for Generations X and Y. London: Equinox.

Rasmussen, Mary Lou. 2006. Becoming Subjects: Sexualities and Secondary Schooling. New York: Routledge.

Ron, James. 2010. “Canada Adrift in Religious World. The Star, July 29. 
Shipley, Heather. 2018. Apathy or Misunderstanding? Youth's Reflections on their Religious Identity in Canada. In Youth, Religion and Identity in a Globalising Context. Edited by Paul L. Gareau, Spencer Culham Bullivant and Peter Beyer. Leiden: Brill, pp. 191-211.

Singleton, Andrew, Mary Lou Rasmussen, Anna Halafoff, and Gary D. Bouma. 2019. Australia's Generation Z Study: Australia's Teenagers Negotiating Religion, Sexuality and Diversity. Project Report. Melbourne: Deakin University.

Vertovec, Steven. 2007. Superdiversity and its Implications. Ethnic and Racial Studies 30: 1024-54. [CrossRef]

Woodhead, Linda. 2012. New Forms of Public Religion: Findings and Reflections from the AHRC/ESRC Religion and Society Programme. Paper presented at the New Forms of Public Religion Conference, St. John's College, Cambridge, UK, September 5-7.

Young, Pamela D. 2018. Influences of Religion on the Sexual Attitudes and Practices of Canadian Youth: The Case of Premarital Sex. In Youth, Religion and Identity in a Globalizing Context. Edited by Paul L. Gareau, Spencer Culham Bullivant and Peter Beyer. Leiden: Brill, pp. 66-77.

Young, Pamela D., and Heather Shipley. 2020. Identities under Construction: Religion, Gender and Sexuality among Youth in Canada. Montreal: McGill Queen's University Press.

(C) 2020 by the authors. Licensee MDPI, Basel, Switzerland. This article is an open access article distributed under the terms and conditions of the Creative Commons Attribution (CC BY) license (http://creativecommons.org/licenses/by/4.0/). 
MDPI

St. Alban-Anlage 66

4052 Basel

Switzerland

Tel. +41616837734

Fax +41 613028918

www.mdpi.com

Religions Editorial Office

E-mail: religions@mdpi.com

www.mdpi.com/journal/religions





MDPI

St. Alban-Anlage 66

4052 Basel

Switzerland

Tel: +41 616837734

Fax: +41 613028918

www.mdpi.com 